\title{
Direito internacional e direito internacional dos direitos humanos
}

Flávia Piva Almeida Leite, José Sérgio da Silva Cristóvam, Maria Creusa de Araújo Borges,

Paulo Roberto Barbosa Ramos

(coords.) 



\section{COMITÉ CIENTÍFICO}

\section{SERIE LEFIS}

\section{Coordinación}

Prof. Fernando Galindo Ayuda. Universidad de Zaragoza

Profa. María Pilar Lasala Calleja. Universidad de Zaragoza

Consejo asesor

Prof. Javier García Marco. Universidad de Zaragoza

Prof. Alejando González-Varas Ibáñez. Universidad de Zaragoza

Prof. Philip Leith. Universidad Queen's de Belfast

Prof. Emérito Abdul Paliwala. Universidad de Warwick

Prof. Aires Rover. Universidad Federal de Santa Catarina

Prof. Erich Schweighofer. Universidad de Viena

Prof. Ahti Saarenpää. Universidad de Rovaniemi 
DIREITO INTERNACIONAL

E DIREITO INTERNACIONAL

DOS DIREITOS HUMANOS 



\section{DIREITO INTERNACIONAL E DIREITO INTERNACIONAL DOS DIREITOS HUMANOS}

Flávia Piva Almeida Leite, José Sérgio da Silva Cristóvam, Maria Creusa de Araújo Borges, Paulo Roberto Barbosa Ramos (coords.) 
DIREITO internacional e Direito internacional dos direitos humanos [Recurso electrónico] / Flávia Piva Almeida Leite... [et al.] (coords.). — Zaragoza : Prensas de la Universidad de Zaragoza, 2019

287 p. ; $22 \mathrm{~cm}$. - (LEFIS series ; 24)

ISBN 978-84-17633-58-5

1. Informática-Derecho. 2. Internet en la administración pública. 3- Derecho internacional. 4. Derechos humanos

LEITE, Flávia Piva Almeida

34:004

004.738.5:35

004.738:341

004.738:342.7

Cualquier forma de reproducción, distribución, comunicación pública o transformación de esta obra solo puede ser realizada con la autorización de sus titulares, salvo excepción prevista por la ley. Diríjase a CEDRO (Centro Español de Derechos Reprográficos, www.cedro.org) si necesita fotocopiar o escanear algún fragmento de esta obra.

(C) LEFIS

(C) CONPEDI, Conselho Nacional de Pesquisa e Pós-Graduação em Direito Brasil.

(C) De la presente edición, Prensas de la Universidad de Zaragoza (Vicerrectorado de Cultura y Proyección Social)

1. ${ }^{a}$ edición, 2019

El Centro Universitário de João Pessoa - PB - UNIPÊ ha subvencionado parcialmente la edición de este libro.

Prensas de la Universidad de Zaragoza. Edificio de Ciencias Geológicas, c/ Pedro Cerbuna, 12. 50009 Zaragoza, España. Tel.: 976761 330. Fax: 976761063

puz@unizar.es http://puz.unizar.es

https://www.conpedi.org.br/

Esta editorial es miembro de la UNE, lo que garantiza la difusión y comercialización de sus publicaciones a nivel nacional e internacional. 


\section{SUMÁRIO}

\section{DIREITO INTERNACIONAL}

APRESENTAÇÃO 9

Paulo Roberto Barbosa Ramos, José Sérgio da Silva Cristóvam.

A FORÇA JURÍDICA DA DECLARAÇÃO UNIVERSAL DOS DIREITOS DOS ANIMAIS.

Heron José de Santana Gordilho, Fernando de Azevedo Alves Brito.

A POSSE DE ARMAS NUCLEARES POR ESTADOS REVISIONISTAS

Filipe Augusto Silva, Renata Mantovani de Lima.

CONFLITO INTERNACIONAL ENTRE A BOLÍVIA E O CHILE POR UM ACESSO

PLENO E SOBERANO AO OCEANO PACÍFICO PARA A BOLÍVIA

André Vinícius Guimarães de Carvalho, Paulo Joviniano Alvares dos Prazeres.

DELIMITAÇÃO MARÍTIMA NO MAR NEGRO NOS TERMOS DA CONVENÇÃO DAS

NAÇÕES UNIDAS SOBRE O DIREITO DO MAR.

Flávia Fagundes Carvalho de Oliveira, Cristiane Araújo Mendonça Saliba.

LA GOBERNANZA GLOBAL DE LOS CAMBIOS CLIMÁTICOS Y EL ROL DE LOS

GOBIERNOS SUBNACIONALES.

Fernando Rei, Mariângela Mendes Lomba Pinho.

QUESTÕES SOBRE A EFICÁCIA DO DIREITO INTERNACIONAL NO

DESENVOLVIMENTO ECONÔMICO BRASILEIRO: 2004-2014. 101

Carlos Leonardo Loureiro Cardoso.

RAÍZES HISTÓRICAS E PERSPECTIVAS DOS DESAFIOS POLÍTICOS E DIPLOMÁTICOS IMPOSTOS À INTEGRAÇÃO REGIONAL SUL-AMERICANA........117 William Paiva Marques Júnior.

\section{DIREITO INTERNACIONAL DOS DIREITOS HUMANOS}

APRESENTAÇÃO

Flávia Piva Almeida Leite, Maria Creusa de Araújo Borges.

COOPERAÇÃO JURÍDICA INTERNACIONAL: TORTURA COMO CRIME CONTRA A HUMANIDADE E A JUSTIÇA DE TRANSIÇÃO NO BRASIL.

Iranice Gonçalves Muniz.

DIREITOS HUMANOS E CONFLITOS ARMADOS: AS CONTRADIÇÕES E PERSPECTIVAS DA COMUNIDADE INTERNACIONAL

Kiwonghi Bizawu.

DOS RECENTES FLUXOS MIGRATÓRIOS NO BRASIL: DA DISCRIMINAÇÃO E DA INVISIBILIDADE SOCIAL 173 Valéria Silva Galdino Cardin, Tereza Rodrigues Vieira. 
ESTADO DEMOCRÁTICO DE DIREITO E A HUMANIZAÇÃO E ACOLHIMENTO À PESSOA IDOSA COMO RESPEITO À DIGNIDADE HUMANA E À CIDADANIA: CONSIDERAÇÕES DE CARÁTER NORMATIVO E CULTURAIS

Cláudia Mansani Queda De Toledo, Flávia Piva Almeida Leite.

O EXERCÍCIO PROGRESSIVO DOS DIREITOS DA CRIANÇA: AS PREMISSAS DA CORTE INTERAMERICANA DE DIREITOS HUMANOS SOB A PERSPECTIVA DOS ACORDOS ARGUMENTATIVOS PROPOSTOS POR PERELMAN E OLBRECHTSTYTECA.

Sergio Ruiz Díaz Arce.

OS LIMITES DE REALIZAÇÃO DOS DIREITOS HUMANOS E SEU CONDICIONAMENTO À SOBERANIA DO ESTADO-NAÇÃO. REFLEXÕES SOBRE OS REFUGIADOS NA TEORIA DE HANNAH ARENDT.

Ridivan Clairefont de Souza Mello Neto, Loiane da Ponte Souza Prado Verbicaro.

PESSOAS COM DEFICIÊNCIA: DA SEGREGAÇÃO À PROTEÇÃO

INTERNACIONAL

Adriana Fasolo Pilati Scheleder, Janaina de Oliveira.

TRIBUNAL HÍBRIDO DO CAMBOJA: INSTRUMENTO JUDICIAL PARA A PROTEÇÃO DOS DIREITOS HUMANOS. .270

Renata Mantovani de Lima. 


\section{DIREITO INTERNACIONAL}

\section{APRESENTAÇÃO}

O VIII Encontro Internacional do CONPEDI, ocorrido entre os dias 06 e 08 de setembro de 2018, na milenar, histórica e mui acolhedora Zaragoza (Espanha), ofereceu aos seus participantes conferências, painéis e grupos de trabalho de destacada qualidade, a exemplo o Grupo de Trabalho "Direito Internacional", que reuniu um qualificadíssimo grupo de pesquisadores de todas as regiões do Brasil, com trabalhos de pertinência acadêmica e grande relevância prática.

Os artigos apresentados se destacaram pelo apuro intelectual, com discussões de sensível qualidade e sobre os mais variados temas do Direito Internacional na atualidade, com destaque para a América Latina, com o envolvimento dos alunos de mestrado e doutorado, professores e profissionais, a partir de discussões respeitosas e marcadas por uma perspectiva dialógica horizontal, democrática, aberta e plural.

Os artigos aqui publicados gravitam em torno das seguintes temáticas:

1. A FORÇA JURÍDICA DA DECLARAÇÃO UNIVERSAL DOS DIREITOS DOS ANIMAIS

2. A POSSE DE ARMAS NUCLEARES POR ESTADOS REVISIONISTAS

3. CONFLITO INTERNACIONAL ENTRE A BOLÍVIA E O CHILE POR UM ACESSO PLENO E SOBERANO AO OCEANO PACÍFICO PARA A BOLÍVIA

4. DELIMITAÇÃO MARÍTIMA NO MAR NEGRO NOS TERMOS DA CONVENÇÃO DAS NAÇÕES UNIDAS SOBRE O DIREITO DO MAR

5. LA GOBERNANZA GLOBAL DE LOS CAMBIOS CLIMÁTICOS Y EL ROL DE LOS GOBIERNOS SUBNACIONALES 
6. QUESTÕES SOBRE A EFICÁCIA DO DIREITO INTERNACIONAL NO DESENVOLVIMENTO ECONÔMICO BRASILEIRO: 2004-2014.

\section{RAÍZES HISTÓRICAS E PERSPECTIVAS DOS DESAFIOS POLÍTICOS E DIPLOMÁTICOS IMPOSTOS À INTEGRAÇÃO REGIONAL SUL-AMERICANA}

Um rico conjunto de temáticas, a demonstrar a contemporaneidade das discussões sobre o Direito Internacional na atualidade.

Estamos honrados pela Coordenação desse relevante Grupo de Trabalho (GT), com o registro da satisfação em podermos debater com todos os autores e demais participantes.

Por fim, registramos os cumprimentos ao CONPEDI, pela já costumeira qualidade dos encontros, e agradecemos aos colegas da Universidade de Zaragoza (Espanha) pela acolhida que tivemos na UNIZAR - nesse relevante momento de divulgação da pesquisa científica na área do Direito. Uma cultura, culinária, história milenar e hospitalidade que conquistaram a todos nós!

Esperamos que os leitores apreciem essa coletânea!

Zaragoza, setembro de 2018.

Coordenadores do GT:

Prof. Dr. Paulo Roberto Barbosa Ramos - Universidade Federal do Maranhão (UFMA)

Prof. Dr. José Sérgio da Silva Cristóvam - Universidade Federal de Santa Catarina (UFSC) 
A FORÇA JURÍDICA DA DECLARAÇÃO UNIVERSAL DOS DIREITOS DOS ANIMAIS

Heron José de Santana Gordilho

Universidade Federal da Bahia (UFBA)

Fernando de Azevedo Alves Brito

Universidade Federal da Bahia (UFBA)

Instituto Federal de Educação, Ciência e Tecnologia da Bahia (IFBA)

\begin{abstract}
Resumo
O presente artigo analisa a Declaração Universal dos Direitos dos Animais (DUDA), enquanto fonte de Direito Internacional Público (DIP). A pesquisa utiliza o método histórico-evolutivo e a técnica de pesquisa bibliográfica e documental. Inicialmente identifica a origem e desenvolvimento histórico da DUDA, para em seguida analisar a influência da DUDA nas normas constitucionais, infraconstitucionais e na jurisprudência brasileira. Por fim, demonstra que a DUDA, enquanto declaração de princípios, integra ao rol das novas fontes de DIP, dotadas de caráter indicativo, mas capaz de influenciar a criação normas constitucionais, infraconstitucionais e decisões judiciais.
\end{abstract}

Palavras-chave: Novas fontes do direito internacional público, Normas de soft law, Declaração de Princípios.

\title{
Abstract/Resumen/Résumé
}

This article analyzes the Universal Declaration of the Rights of Animals (DUDA) as a source of Public International Law (PIL). The research uses historical-evolutionary method and the bibliographical and documentary research technique. Initially, it identifies the origin and historical development of the UDAR, and then analyzes the influence of the UDAR on constitutional, infraconstitutional norms and Brazilian precedents. Finally, it shows that UDAR, as a declaration of principles, integrate the list of new sources of IPD, which are indicative but can influence constitutional, constitutional and judicial decisions.

Keywords/Palabras-claves/Mots-clés: New sources of public international law, Soft law standards, Statements of principles. 


\section{Introdução}

A Declaração Universal dos Direitos dos Animais (DUDA) tem sido referenciada em trabalhos científicos, textos jornalísticos e publicações de outras naturezas, não sendo incomum encontrar menções a este documento em sites de Organizações NãoGovernamentais especializadas na causa animalista, e, até mesmo, em sites governamentais

Muitas dúvidas existem acerca da origem da DUDA, bem como de sua caracterização como uma declaração de princípios propriamente dita, à semelhança da Declaração Universal de Direitos Humanos da Organização das Nações Unidas (ONU), e essas dúvidas se referem desde a sua suposta "institucionalização" pela UNESCO, até o rol de países signatários, o seu valor como fonte de direito internacional e a sua força jurídica.

É importante destacar que a DUDA é um documento singular, composto por um extenso rol de direitos destinados aos animais, tais como igualdade, respeito, proteção/cuidado, liberdade, dignidade, proteção contra maus tratos e atos cruéis (CFMV, 2017).

Em uma época de debates sobre as consequências do pós-humanismo no Direito e sobre a consolidação progressiva do Direito Animal, a DUDA não deixa de ser um instrumento interessante e diferenciado que precisa ser analisado, o que, por si só, já justifica a realização do presente trabalho, que buscará responder a seguinte questão-problema: a DUDA é uma fonte de Direito Internacional Ambiental?

Os objetivos específicos deste artigo serão: (a) identificar, através de documentos, a origem e o desenvolvimento histórico da DUDA; (b) demonstrar a influência da DUDA na Assembleia Nacional Constituinte de 1987-1988, especialmente na redação do artigo 226, VII da CF; (c) identificar a influência da DUDA em normas infraconstitucionais e na jurisprudência brasileira; e (e) identificar a natureza jurídica da DUDA em face do Direito Internacional Público.

O método de pesquisa utilizado será o histórico-evolutivo, analisando os antecedentes e as condições que precederam a DUDA, ao passo que a técnica de pesquisa será a bibliográfica e documental, com acesso a informações oficiais, diários da Assembleia Nacional Constituinte, normas jurídicas e decisões judiciais.

\section{Declarações de princípios como normas de soft law}

Desde o início do século XIX as conferências internacionais têm adotado normas de 
soft law na forma de resoluções não-obrigatórias endereçadas aos Estados, na forma de recomendações ou declarações de princípios, mas, também, os comunicados conjuntos, atas, códigos de conduta ou acordos de cavalheiros, normas que têm causado um forte impacto no direito internacional ambiental (GORDILHO, 2011).

A enumeração das fontes prevista no art. 38 do Estatuto do TIJ não é taxativa, de modo que é possível identificar novas fontes de direito internacional, tais como os atos unilaterais, que se manifestam através de declarações de vontade emitidas pelos Estados, isoladamente ou em conferências internacionais; os atos de organizações intergovernamentais, como a Organização Mundial de Saúde (OMS), a Organização Internacional do Trabalho (OIT) e a UNESCO, e os atos internacionais unilaterais de instâncias não personalizadas, que muitas vezes funcionam como verdadeiras fontes autônomas ${ }^{1}$.

Os atos unilaterais coletivos proclamados por instâncias desprovidas de personalidade jurídica, sob a forma de conclusões ou declarações, proclamadas em conferências internacionais, têm o objetivo de harmonizar interesses comuns e uniformizar os instrumentos políticos para enfrentar os problemas internacionais (MAZZUOLI, 2014).

Sabe-se que essas instâncias, não possuindo personalidade jurídica, não estariam aptas a praticar atos jurídicos em nome próprio, de modo que os seus atos devem ser imputados aos Estados participantes, de modo que muitos consideram esses atos como negócios jurídicos multilaterais na modalidade convenção simplificada ou negócios jurídicos unilaterais na modalidade ato coletivo.

Estas normas jurídicas internacionais, ditas de soft law, via de regra são o fruto de um compromisso entre Estados quando uma regulação definitiva não consegue consenso (MELLO, 2001).

Tais normas decorrem de documentos declaratórios provenientes de foros internacionais sem caráter de obrigatoriedade, e uma vez que elas não vinculam os Estados, elas também não permitem que Estados ou seus idadãos sejam levados aos tribunais nacionais ou internacionais pela sua violação ou inobservância (MENEZES, 2003).

Enquanto as normas provenientes das fontes normativas clássicas, especialmente o costume, as convenções internacionais e os princípios gerais de direito são consideradas

\footnotetext{
${ }^{1}$ Para J. F. Resek (2000, p. 132), "Poder-se-ia debitar esta omissão à circunstância de que o rol foi originalmente lavrado em 1920, quando apenas começava a era das organizações internacionais, e copiado - sem maior ânimo de aperfeiçoamento ou atualização - em 1945.”.
} 
normas hard law, por virem acompanhadas de sanções que as podem tornar efetivas, as normas de soft law não preveem sanções para os casos de descumprimento (CRETELA NETO, 2012).

Estas normas internacionais de soft law possuem a dupla função de fixar metas para futuras ações políticas nas relações internacionais e de recomendar aos Estados que se adéquem aos seus princípios e regras (SOARES, 2001).

Elas podem assumir a forma de recomendações diretivas, atos das organizações intergovernamentais enviados para os Estados-membros para que estes se reservam ao direito de avaliar a situação e decidir se aplicam ou não suas resoluções; programas de ação, dirigidos às próprias organizações que os elaboram, estabelecendo atividades que devem ser empreendidas num determinado período de tempo, a exemplo da Agenda 21; ou declarações de princípios, adotadas e proclamadas em nome da sociedade internacional pelas organizações ou em conferências internacionais (KISS; SHELTON, 1991).

Não obstante isso, saber se as declarações de princípios adotadas através de resoluções da Assembleia Geral da ONU, tais como a Declaração Universal dos Direitos Humanos de 1948, a Declaração sobre a Soberania Permanente sobre Recursos Naturais de 1962 ou a Declaração sobre a Eliminação de Todas as Formas de Discriminação Racial de 1963, são fontes do Direito Internacional Público (DIP) continua a ser uma questão controvertida.

É que embora essas declarações não sejam fontes autônomas, elas delimitam o âmbito de possibilidade de novos direitos, identificando as diretrizes de sua evolução, exercendo, assim, uma grande influência na formação dos costumes ou na celebração de convenções. Além de vincularem os organismos que as elaboraram nas suas relações com os Estados membros, essas normas desempenham, muitas vezes, a função de fonte material ou direta qualificada (MONCADA, 1998).

Em verdade, essas declarações de princípios não contemplam ações precisas para serem cumpridas, e se limitam a estabelecer valores e objetivos gerais, muitas vezes exercendo forte influência na criação de novas regras jurídicas e nas decisões judiciais de tribunais nacionais e internacionais.

Vejamos o exemplo da Declaração Universal dos Direitos Humanos (DUDH), que foi adotada sob a forma de resolução pela Assembleia Geral da ONU e tem sido respeitada e observada pela maioria dos Estados como uma verdadeira fonte de direito internacional.

Alguns publicistas consideram esta declaração um conjunto de norma costumeiras e/ou de princípios gerais de direito internacional com força vinculante, considerando que 
grande parte das suas normas já foram positivadas em constituições do mundo democrático ${ }^{2}$.

Muitas decisões proferidas pelos tribunais nacionais se referem à Declaração Universal dos Direitos do Homem como princípios gerais do direito, pois de acordocom os arts. $1^{\circ}$ (3) e 55 da Carta das Nações, os Estados assumiram o compromisso de assegurar o respeito universal e efetivo pelos direitos humanos, de modo que a DUDH teria, ao menos, o efeito negativo de deslegitimar as normas dos Estados que violem sistematicamente os seus preceitos (PIOVESAN, 2000).

Apesar disso, os princípios proclamados em declarações internacionais como a Declaração de Estocolmo e a Declaração do Rio ainda não influenciam a legislação dos Estados da mesma maneira que a DUDH.

Não obstante, outras declarações de princípios com objetivos mais limitados como a Carta Europeia da Água sobre Poluição Transfronteiriça, a Recomendação da OCDE de 1974 e os princípios de conduta declarados pela UNEP em 1978, têm influenciado a legislação de diversos Estados.

Acontece que mesmo as Declarações aprovadas por unanimidade pela Assembleia Geral da ONU possuem natureza jurídica de recomendações, sendo vinculantes apenas para a própria organização e não para os Estados membros.

Embora elas não possam ser consideradas fontes autônomas, essas declarações delimitam o âmbito de possibilidade do novo direito, identificando as diretrizes da evolução jurídica e exercendo uma grande influência na formação dos costumes e na celebração de novas convenções, além de vincularem os organismos que as elaboraram em suas relações com os Estados membros, desempenhando, muitas vezes, a função de fonte direta qualificada (MONCADA, 1998).

É que através dessas declarações de vontade, os Estados demonstram a intenção de assumir compromissos políticos não vinculantes, embora elas possam ser utilizadas pelos tribunais nacionais, já que, para Virally ${ }^{3}$, um Estado só pode se recusar o seu cumprimento quando existe uma justificação de fato e de direito (MELLO, 2001).

Para muitos autores, embora estas novas fontes de direito internacional retirem seu fundamento de validade dos costume ou dos tratados internacionais (Quadri), elas funcionam

\footnotetext{
${ }^{2}$ Sobre as declarações de Estocolmo e do Rio, Soares (2001, p. 200) afirma que "De nossa parte, preferimos considerar ambas as Declarações como uma notável consolidação de princípios gerais de direito, não tanto pelo fato de terem sido adotadas pelos Estados durante uma conferência especial ad doc, ainda que sob a égide da ONU [...] mas por seu conteúdo e finalidade.”.

${ }^{3}$ Segundo Mello (2001), pode-se recordar que algumas decisões de tribunais internos (EUA, Japão, Itália) têm invocado resoluções da ONU. Para Bedjaoui a resolução se aproxima "de um direito transitório, uma espécie de pré-direito que põe fim ao direito antigo e precede o novo direito".
} 
mais como instrumentos de integração (Chaumont) do que como fonte propriamente dita. Outros as consideram simplesmente atos de execução (Delbez) ${ }^{4}$.

\section{A Declaração Universal dos Direitos dos Animais e a UNESCO}

No Brasil, uma das primeiras referências doutrinárias à DUDA foi a da professora Edna Cardoso Dias, que em sua obra seminal A tutela jurídica dos animais afirmou que a Declaração foi criada pela UNESCO, em sessão realizada em Bruxelas, Bélgica, em 27 de janeiro de 1978, e que o Brasil teria sido um dos signatários deste documento (CFVM, 2017; DIAS, 2000).

Acontece que após uma simples busca na internet, pode-se perceber que esse documento sequer é mencionado no site da UNESCO (MURAL ANIMAL, 2014), o que, por si só, já poderia indicar o equívoco.

Em 05 de junho de 2016, efetuou-se uma consulta formal ao Ministério das Relações Exteriores do Brasil, através do seu portal de informação (https://esic.cgu.gov.br), indagando sobre: (a) a natureza da DUDA; (b) o cronograma da participação do Estado Brasileiro (com datas específicas, local e conteúdo) nas atividades pertinentes à formalização dessa Declaração; e, ainda, (c) a existência de registros/arquivos históricos (atas de reuniões, ofícios, outros documentos etc.) da participação do Brasil no processo de elaboração dessa Declaração.

Em resposta, o Ministério das Relações Exteriores forneceu as seguintes informações:

[...] informamos que não há, nos arquivos da Divisão de Atos Internacionais (DAI/MRE), qualquer registro sobre a Declaração em apreço, a qual não se caracteriza como ato internacional formal. Desse modo, não cabe falar em Estadosparte, adesão, ratificação, promulgação ou vigência. Considerando o teor das perguntas formuladas, e tendo presente que a declaração, conforme apurado na internet, foi "adotada" em reunião da UNESCO, em Bruxelas, em 27 de janeiro de 1978, ou "proclamada" no prédio da UNESCO, em Paris em 15 de outubro de 1978, não se trata, portanto, de um ato internacional formal (logo não há internalização). Seria necessária uma pesquisa nos arquivos do Itamaraty para averiguar se há registros ou arquivos da participação do Brasil no processo de elaboração de Declaração em tela, já que ela foi assinada em 1978. [...] (MINISTÈRIO DAS RELAÇÕES EXTERIORES, 2016, p. 1).

\footnotetext{
${ }^{4}$ Mello (2001, p. 290): "Não interessa a questão de sabermos se são fontes do segundo ou terceiro grau. A questão realmente importante nesse assunto consiste em sabermos se são ou não normas jurídicas pelas quais os Estados devem pautar a sua conduta e, neste sentido, a resposta é afirmativa. Deste modo, os atos unilaterais são fontes do DI.”.
} 
Ora, o Ministério das Relações Exteriores informou não haver nenhum registro da DUDA nos arquivos da DAI/MRE, o que evidência que a DUDA não é um ato unilateral de uma organização intergovernamental como a UNESCO.

Por outro lado, constatou-se que a incerteza acerca do referido documento é tão significativa - até mesmo em nível governamental -, que o próprio Ministério precisou recorrer à internet para prestar parcela das informações solicitadas ${ }^{5}$.

No dia 16 de junho de 2016, fez-se, via e-mail, semelhante consulta ao Centro de Informação das Nações Unidas no Brasil (UNIC Rio), que prestou as seguintes informações:

\begin{abstract}
A UNESCO informa que não é de sua autoria a referida Declaração, e isso está correto, evidentemente - cabe à UNESCO primariamente essa checagem, mas confirmamos também essa informação.

[...] A ONU desconhece um documento supostamente chamado 'Declaração Universal dos Direitos Animais', que não é de autoria desta Organização. Não há qualquer menção a um documento deste tipo ('Universal Declaration on Animal Welfare') nem na Assembleia Geral das Nações Unidas nem em qualquer outro órgão do Sistema ONU.

[...] A mencionada Declaração, no entanto, não pertence à ONU, e portanto peço desculpas por não poder responder sobre sua origem (ONU, 2016, p. 1).
\end{abstract}

A Unidade de Gestão de Arquivos e Registros da UNESCO, por seu turno, em resposta à consulta oficial realizada pelo biólogo Frank Alarcón, em 23 de setembro de 2014, informou:

De fato, a UNESCO não aprovou a Declaração Universal dos Direitos dos Animais. Esta declaração foi adotada em Londres pela Liga Internacional dos Direitos dos Animais (hoje: Fondation Droit Animal,

Ethique et Sciences), em setembro de 1978, e proclamou em Paris, em 15 de outubro de 1978 pela liga acima em uma reunião que foi realizada em um edifício da UNESCO. [...]

Temos três registros em conexão com as relações oficiais entre a Federación Mundial de Proteción Animal (WFPA) e UNESCO. Os registros vêm sempre da unidade da UNESCO de relações com as ONG. [...]. No entanto, a UNESCO não mantém relações oficiais com essa organização. Não há registro de correspondência entre a Liga (autor da Declaração) e da UNESCO [...] (MURAL ANIMAL, 2014) ${ }^{6}$.

\footnotetext{
${ }^{5}$ Não se pretende, aqui, questionar a competência do Ministério das Relações Exteriores na gestão das informações solicitas, até porque a inexistência de registro da DUDA em seus arquivos é um indicativo de sua informalidade, o que foge, portanto, de suas atribuições. O próprio Ministério, aliás, afirma que o documento não se caracteriza como ato internacional formal.

${ }^{6}$ Redação original: “In fact, UNESCO has not endorsed the Universal Declaration of Animal Rights. This declaration was adopted in London by the International League for Animal Rights (today: Fondation Droit Animal, éthique et sciences), in September 1978, and proclaimed in Paris on 15 October 1978 by the above league at a meeting which was held in the UNESCO building. [...] We have three records in connection with the official relations between the Federacion Mundial (WFPA) and UNESCO. The records always come from the UNESCO unit for relations with NGOs. You will find attached an example of the letters exchanged. However, UNESCO does not maintain official relations with this organization. There is no record of correspondence between the League (author of the Declaration) and UNESCO, but you will also find attached the reference to their meeting in the calendar of conferences and meetings for 1978".
} 
De acordo com a Unidade de Gestão de Arquivos e Registros, a DUDA não seria um documento de autoria da UNESCO, mas da antiga Liga Internacional dos Direitos dos Animais (LIDA), de modo que não se pode falar em países signatários.

Na verdade, a DUDA foi proclamada solenemente em Paris, em 5 de outubro de 1978, sendo que, no mesmo dia, o texto foi apresentado ao Diretor geral da UNESCO (NOUËT, 1998, p. 9)

A própria UNESCO informa que, em 1973, a LIDA colaborou com a redação da Convenção Internacional sobre o Comércio de Animais em perigo de Extinção (CITES) e que, em pelo menos duas oportunidades, considerou a possibilidade de formalizar a DUDA o que, infelizmente, não ocorreu (GORDILHO, 2011; MURAL ANIMAL, 2014).

Assim, pode-se constatar que a DUDA não é um ato de nenhuma organização intergovernamental, mas uma simples declaração de princípios proclamada em uma Conferência sobre os direitos dos animais, organizada no ano de 1978 pela ONG Liga Internacional dos Direitos dos Animais (LIDA), atual Fundação Direito Animal, Ética e Ciência ${ }^{7}$.

Como a DUDA não está prevista no rol das fontes de DIP, era de se esperar que ela fosse ignorada pelas instâncias estatais, afinal de contas, trata-se um documento não-oficial, produzido em uma conferência internacional organizada por uma ONG, sem qualquer força vinculante perante os Estados e os tribunais nacionais e internacionais ${ }^{8}$.

Por outro lado, ela não apenas vem servindo de justificativa e fundamentação para a formulação de diversas ações públicas, como também tem sido o fundamento para a criação de vários órgãos e decisões jurídicas destinadas à tutela dos animais.

\section{A influência da Declaração Universal dos Direitos dos Animais no Direito Brasileiro}

A DUDA, por exemplo, foi um dos principais elementos de inspiração para a norma constitucional que proíbe toda e qualquer atividade que submeta os animais à crueldade (art. 225, §1 $\left.{ }^{\circ}, \mathrm{VII}\right)$ (BRASIL, 1988).

\footnotetext{
${ }^{7}$ Nouet (1998, p.9), por exemplo, afirma que "A DUDA foi divulgada solenemente em Paris em 5 de outubro de 1978 e no mesmo dia o texto foi apresentado ao Diretor geral da UNESCO".

${ }^{8}$ Aliás, ainda que a DUDA fosse uma Declaração propriamente dita, criada pela UNESCO, não seria mais do que uma declaração política, desprovida, portanto, de imperatividade.
} 
É que durante os trabalhos da Assembleia Constituinte de 1987, o Deputado Federal Fábio Feldman designou um representante de cada Estado para fazer a defesa dos artigos do capítulo sobre meio ambiente perante os constituintes.

$\mathrm{Na}$ oportunidade, coube à professora Edna Cardoso Dias, então presidente da Liga de Prevenção da Crueldade contra o Animal (LPCA), fazer a defesa do artigo art. 225, $\S 1^{\circ}$, VII, em evento ocorrido no Auditório Nereu Ramos, em Brasília, no dia 5 de junho de 1987, perante o relator da Constituinte, o Senador Bernardo Cabral ${ }^{9}$.

É importante destacar que existe uma referência expressa à DUDA no discurso do próprio deputado constituinte Fábio Feldmann, o qual critica a prática da farra do boi no Estado de Santa Catarina. O referido discurso foi publicado nos Diários da Assembleia Nacional Constituinte de 1987-1988, verbis:

[...] Por sua vez, se tratando de Constituinte, provou a 'Farra do Boi' a necessidade de se criar um dispositivo constitucional que proteja os animais de práticas que o submetam a sacrifícios indesejados e desnecessários. Nesse particular, é preciso lembrar a Declaração Universal dos Direitos do Animal, objeto de tratado internacional do qual o Brasil é signatário, que, no seu artigo $2^{\circ}$ estabelece que 'cada animal tem direito ao respeito', e 'o homem, enquanto espécie animal, não pode atribuir-se o direito de exterminar outros animais ou de explorá-los, violando esse direito'. Ainda, com relação à 'Farra do Boi', informo que requeri à Procuradoria-Geral da República medidas judiciais que venham a assegurar a nãorealização de tais crimes, com base na lei dos interesses difusos e no Decreto $\mathrm{n}^{\circ}$ 24.645 , de 10 de julho de 1934 - embora antigo, ainda vigente - cujo artigo $1^{\circ}$ prescreve que 'todos os animais do País são tutelados do Estado' (BRASIL, 1987, p. 351-352).

Note-se que a DUDA foi citada pelo deputado como um tratado internacional do qual o Brasil seria signatário. Sendo assim, a DUDA não só era de conhecimento dos Deputados da Assembleia Nacional Constituinte de 1987-1988, como os constituintes a consideravam uma norma vinculante de Direito Internacional Público.

Além da referência expressa à DUDA nos Diários da Assembleia Nacional Constituinte de 1987-1988, como uma típica norma de Direito Internacional Público, encontramos outra referência a ela na Resolução n ${ }^{0}$ 7.499/2013 da Polícia Civil de Minas Gerais, que criou a Delegacia Especializada de investigação de Crime Contra a Fauna (DEICCF).

\footnotetext{
${ }^{9}$ Por mensagem de Whatsapp a professora Edna Cardoso Dias informou que; "A informação circulava e não sei se usou dos meus escritos porque todos falavam o mesmo. Que a UNESCO havia endossado a DUDA e que o Brasil era signatário. Inclusive me correspondia com ONGs de outros países que assim me informaram [...]. Todo o meu material veio de correspondências com ONGs da Europa e dos USA, que me doavam livros, revistas [...]". Mensagem recebida em 8 de maio de 2018.
} 
Em suas considerações iniciais, a Resolução justifica a criação de uma nova Delegacia com base nos preceitos estabelecidos pela DUDA:

Considerando que a Declaração Universal dos Direitos dos Animais, proclamada pela Organização das Nações unidas para a Educação, a Ciência e a Cultura (UNESCO), em 27 de janeiro de 1978, da qual o Brasil é signatário, dispõe que todos os animais nascem iguais diante da vida e têm o direito à existência, ao respeito, à cura e à proteção do homem;

Considerando que, nos termos da mesma Declaração, nenhum animal deverá ser submetido a maus tratos ou a atos cruéis e, sendo sua morte necessária, deve ser instantânea, sem dor e angústia; [...] (POLÍCIA CIVIL DO ESTADO DE MINAS GERAIS, 2016, p.1).

Situação idêntica ocorreu com o Decreto $n^{\circ} 12.567 / 2017$, que criou, na Secretaria Executiva do Município de Niterói/RJ, a Coordenadoria Especial de Direito dos Animais:

O PREFEITO DO MUNICÍPIO DE NITERÓI, no uso das atribuições que lhe são conferidas por lei;

CONSIDERANDO a Declaração Universal dos Direitos dos Animais proclamada pela UNESCO em sessão realizada em Bruxelas - Bélgica, em 27 de janeiro de 1978; [...] (NITERÓI, 2017, p.1).

A jurisprudência brasileira cita, de igual modo, a DUDA como fonte de DIP: (a) a Apelação Cível no 12.301 MS (0012031-94.2008.4.03.6000), julgada, em 12 de setembro de 2012, pela Quarta Turma, do Tribunal Regional Federal da 3ª Região (BRASIL, 2012); (b) os Embargos Infringentes na Apelação Cível nº 21.481 RS (2004.71.00.021481-2), julgados, em 13 de março de 2008, pela Segunda Seção, do Tribunal Regional Federal da $4^{\text {a }}$ Região (BRASIL, 2008); e (c) uma Ação Civil Pública da $3^{\mathrm{a}}$ Vara Cível de Rondonópolis/MT, sentença de 06 de novembro de 2015, proferida pela Juíza Milene Beltramini.

No primeiro caso, ao avaliar-se a legalidade da Portaria Interministerial $n^{0} 1.426$ MAPA, a decisão judicial citou a DUDA em duas oportunidades:

a. A Portaria n. ${ }^{\circ} 1.426$ revela-se ilegal, ainda, por afrontar a legislação protetiva do meio ambiente, especialmente a Lei $n .^{\circ}$ 9.605/98, que tipifica, dentre os crimes ambientais, aqueles que são cometidos contra a fauna, e também a Declaração Universal dos Direitos dos Animais, proclamada em assembleia da Unesco, em Bruxelas, no dia 27 de janeiro de 1978, que regulamenta a matéria no âmbito internacional, e que foi recepcionada pelo nosso sistema jurídico.

b. A proteção dos animais em relação às práticas que possam provocar sua extinção ou que os submetam à crueldade é decorrência do direito da pessoa humana ao meio ambiente ecologicamente equilibrado, previsto no inciso VII do $\S 1^{\circ}$ do artigo 225 do texto constitucional.

c. A Constituição Federal, a Declaração de Bruxelas e as leis de proteção a fauna conduzem-se no sentido da proteção tanto da vida como contra os maus tratos. A vedação de medicamentos usados para humanos ou dos não registrados para aliviar ou evitar a doença em causa, desde que prescritos por quem de direito, representa séria violação e desrespeito aos estatutos mencionados (BRASIL, 2012, p. 1-3). 
No segundo caso, ao avaliar-se a proibição de caça amadorística no Estado do Rio Grande do Sul, a decisão judicial também citou a DUDA:

Com razão a sentença ao proibir, no condão do art. 225 da Constituição Federal, bem como na exegese constitucional da Lei n..$^{\circ}$ 5.197/67, a caça amadorista, uma vez carente de finalidade social relevante que lhe legitime e, ainda, ante à suspeita de poluição ambiental resultante de sua prática (irregular emissão de chumbo na biosfera), relatada ao longo dos presentes autos e bem explicitada pelo MPF. Ademais, I. proibição da crueldade contra animais - art. $225, \S 1^{\circ}$, VII, da Constituição - e a sua prevalência quando ponderada com o direito fundamental ao lazer, II. incidência, no caso concreto, do art. 11 da Declaração Universal dos Direitos dos Animais, proclamada em 1978 pela Assembleia da UNESCO, o qual dispõe que o ato que leva à morte de um animal sem necessidade é um biocídio, ou seja, um crime contra a vida e III. necessidade de consagração, in concreto, do princípio da precaução.3. Por fim, comprovado potencial nocivo do chumbo, metal tóxico encontrado na munição de caça.4. Embargos infringentes providos (BRASIL, 2008, p. 1).

No terceiro caso, ao avaliar-se as iniciativas da Prefeitura Municipal de Rondonópolis em desfavor dos animais abandonados, a Juíza responsável determinou que a Prefeitura adotasse medidas para assegurar o bem-estar dos animais abandonados naquele Município com fundamento na Constituição Federal de 1988, mas também na DUDA:

Ainda, está previsto na Declaração Universal dos Direitos dos Animais em seus artigos $2^{\circ}$ e $3^{\circ}$. Veja:

'Art. $2^{\circ}$

1. Todo o animal tem o direito a ser respeitado.

2. O homem, como espécie animal, não pode exterminar os outros animais ou explorá-los violando esse direito; tem o dever de pôr os seus conhecimentos ao serviço dos animais.

3. Todo o animal tem o direito à atenção, aos cuidados e à proteção do homem. Art. $3^{\circ}$

1. Nenhum animal será submetido nem a maus tratos nem a atos cruéis. 2. Se for necessário matar um animal, ele deve de ser morto instantaneamente, sem dor e de modo a não provocar-lhe angústia' (BRASIL, 2015 apud BELTRAMINI, 2015, p. 196).

2.

Como vimos, a DUDA tem sido utilizada no Brasil como fonte direta de DIP, servindo de fundamento para a criação de diversas normas infraconstitucionais e de distintas decisões nos tribunais brasileiros.

\section{A Declaração Universal dos Direitos dos Animais como norma de soft law}

O art. 38, itens 1 e 2, do Estatuto da Corte Internacional de Justiça (CIJ) estabelece que as convenções ou tratados internacionais, os costumes internacionais e princípios gerais de direito das nações civilizadas são as fontes diretas do Direito Internacional Público (DIP), ao passo que a jurisprudência, a doutrina e a equidade são fontes ou instrumentos auxiliares de integração das normas jurídicas internacionais (ONU, 1945). 
Não obstante isso, esse rol não é taxativo, de modo que desde o início do século XIX, as conferências internacionais têm adotado diversas normas de soft law como fontes do DIP, tanto na forma de recomendações ou declarações de princípios, quanto na de comunicados conjuntos, atas, códigos de conduta ou acordos de cavalheiros, o que tem causado um forte impacto no direito internacional do meio ambiente.

Tais normas de soft law normalmente são fruto de compromissos entre os que querem a regulação definitiva de uma matéria e aqueles que não querem (MELLO, 2001), e acabam por assumir a dupla função de fixar metas para futuras ações políticas nas relações internacionais e a de recomendar aos Estados que adéquem os dispositivos do seu ordenamento aos seus princípios e regras (SOARES, 2001).

As recomendações diretivas são atos que as organizações intergovernamentais enviam, por si próprias, para os Estados-membros, para que estes reservem-se ao direito de avaliar a situação e decidir se aplicam ou não as suas resoluções, tais como as recomendações das organizações internacionais como a UNESCO, Organização Mundial de Saúde (OMS), Organização Internacional do Trabalho (OIT).

As recomendações diretivas, que constituem a maioria dos atos pelos quais as organizações intergovernamentais se remetem aos Estados para que estes aceitem espontaneamente certas obrigações, são frequentemente escritas em termos gerais e abstratos, de modo que é preciso que elas sejam detalhadas em cada caso concreto pelos órgãos internos de cada organização.

Os programas de ação, por sua vez, são dirigidos às próprias organizações que os elaboram, e estabelecem atividades que devem ser empreendidas em um determinado período de tempo, a exemplo do Plano de Ação para o Meio Ambiente Humano adotado pela conferência de Estocolmo de 1972, composto de 109 recomendações dirigidas aos governos ou a outras organizações internacionais.

Outro exemplo é a Agenda 21, composta de quarenta capítulos, agrupados em quatro seções, que estabelecem uma lista de prioridades tais como o desenvolvimento sustentável, o combate à pobreza, a proteção da saúde humana, a administração da água e dos resíduos e a poluição, cuja execução será acompanhada pela Comissão para o desenvolvimento Sustentável, que é subordinada aos Conselho Econômico e Social (Ecosoc) da ONU, com eventuais financiamentos do Fundo Ambiental Global (GEF).

As declarações de princípios, diferentemente das recomendações diretivas, não contemplam ações precisas para serem cumpridas, se limitando a fixar linhas gerais, que muitas vezes exercem considerável influência no desenvolvimento de novas regras jurídicas 
e nas decisões tanto no plano internacional quanto no plano interno.

Tais declarações podem ser adotadas e proclamadas em conferências internacionais em nome da sociedade internacional por organizações, e visam o reconhecimento da emergência de novos valores pelo direito (KISS; SHELTON, 1991).

Vejamos o exemplo da Declaração Universal dos Direitos Humanos adotada pela Assembleia Geral da ONU sob a forma de resolução, que tem sido respeitada e observada pelos Estados como verdadeira fonte do direito internacional, muito embora países como a China e outros nem sempre respeitem os seus princípios.

Por outro lado, muitas decisões proferidas pelos tribunais nacionais se referem aos princípios gerais do direito como fonte de direito, tendo em vista que nos arts. $1^{\circ}$ (3) e 55 da Carta das Nações os Estados assumem o compromisso de assegurar o respeito universal e efetivo pelos direitos humanos, de modo que a Declaração Universal dos Direitos Humanos tem ao menos o efeito negativo de deslegitimar todos os Estados que sistematicamente violem seus preceitos (PIOVESAN, 2000).

Com efeito, nos parece, que embora em princípio elas não possam ser consideradas fontes autônomas, essas declarações delimitam o âmbito de possibilidade do novo direito, identificando as suas diretrizes de evolução, exercendo uma grande influência na formação dos costumes ou na celebração de convenções, além de vincularem os organismos que as elaboraram nas suas relações com os Estados membros, desempenhando, muitas vezes, a função de fonte material ou direta qualificada (MONCADA, 1998).

As normas de soft law se encontram em documentos declaratórios provenientes de foros internacionais sem caráter de obrigatoriedade e não vinculam os Estados ao cumprimento expresso de seus dispositivos, de modo que sua inobservância ou violação não ensejam a submissão a instâncias jurisdicionais internacionais (MENEZES, 2003).

Além disso, elas independem de positivação em constituições, leis ou tratados internacionais, pois tratam de exigências de respeito à dignidade humana, exercidas contra os poderes, oficiais ou não (COMPARATO, 2001).

É importante destacar que nem mesmo as declarações aprovadas pela Assembleia Geral da ONU criam princípios gerais de direito internacional, pois, segundo a Carta das Nações, elas são vinculantes apenas para a própria organização.

Para muitos juristas, estas declarações acabam por integrar o direito costumeiro e/ou os princípios gerais de direito internacional, assumindo força vinculante, e produzindo, pelo menos, o efeito negativo de deslegitimar as decisões dos Estados que violem os seus preceitos sistematicamente (GORDILHO, 2017). 
Estes documentos são dotados de caráter indicativo, e acabam por influenciar na criação de futuras convenções internacionais e, até mesmo, a edição de normas constitucionais ou ordinárias (GORDILHO, 2011).

Seja como for, a DUDA vem se constituindo como um importante instrumento para "aclarar pontos", "estabelecer novos parâmetros", "descobrir novos caminhos ainda não pesquisados", "apresentar soluções justas” em relação aos animais, contribuindo, outrossim, na "identificação e no esclarecimento de regras preexistentes" e servindo muitas vezes como "método interpretativo e de colmatação das lacunas da regulamentação" (GORDILHO, 2011).

\section{Conclusão}

A DUDA tem sido utilizada no Brasil como fonte direta de DIP, servindo de fundamento para a criação de diversas normas infraconstitucionais e de diversas decisões nos tribunais brasileiros.

Acontece que a DUDA não foi adotada pela UNESCO, mas fruto de um encontro organizado pela antiga Liga Internacional dos Direitos dos Animais (LIDA), tendo sido divulgada solenemente em 5 de outubro de 1978, na sede da UNESCO, em Paris, sendo no mesmo dia o texto foi apresentado ao Diretor geral da UNESCO, que em pelo menos duas oportunidades considerou a possibilidade de adotá-la, mas não o fez.

Não obstante a isso, a DUDA é uma declaração de princípios que integra o rol das novas fontes do Direito Internacional Público, e, embora seja dotada de mero caráter indicativo, tem exercido uma forte influência no sistema jurídico brasileiro, seja na edição de normas constitucionais, leis ordinárias, mas também na criação de políticas públicas e nas decisões judiciais no interesse dos animais.

\section{Referências}

ACCIOLY, Hildebrando; SILVA, G.E. do Nascimento e; CASELLA, Paulo Borba. Manual de direito internacional público. 20. ed. São Paulo: Saraiva, 2012.

AMARAL JUNIOR, Alberto do. Noções de direito e direito internacional. 3. ed. Brasília: FUNAG/Ministério das Relações Exteriores, 2008.

BELTRAMINI, Milene Aparecida Pereira. Ministério Público do Estado de Mato Grosso v. 
Município de Rondonópolis. Revista Brasileira de Direito Animal v.10 n.20. 2015.

Disponível em: < https://portalseer.ufba.br/index.php/RBDA/article/view/15302>. Acesso em: 05 abr. 2018.

BRASIL. Tribunal Regional Federal da $4^{a}$ Região (2ª Seção). Embargos Infringentes na Apelação Cível nº 21.481 RS (2004.71.00.021481-2) - Rio Grande do Sul. Relator: Carlos Eduardo Thompson Flores Lenz. Pesquisa de Jurisprudência, Julgamento, 13 mar. 2008. Disponível: $<$ https://trf- 4.jusbrasil.com.br/jurisprudencia/1274536/embargos-infringentesna-apelacao-civel- eiac-21481>. Acesso em: 25 jan. 2018.

. Tribunal Regional Federal da 3ª Região. Apelação Cível nº 12.301 MS (0012031-94.2008.4.03.6000) - Mato Grosso do Sul. Relator: Juiz Convocado David Diniz. Pesquisa de Jurisprudência, Julgamento, 13 set. 2012. Disponível em: $<$ http://www.stf.jus.br/portal/jurisprudencia/pesquisarJurisprudencia.asp $>$. Acesso em: 25 jan. 2018.

\section{Constituição da República Federativa do Brasil, de 05 de outubro de}

1988. Disponível em:

$<$ http://www.planalto.gov.br/ccivil_03/constituicao/constituicao.htm>. Acesso em: 25 jan. 2018.

Diários da Assembleia Nacional Constituinte. Ano i, n. 38, quinta-feira, 2 de abril de 1987, Brasília-DF, p. 351-352. Disponível em:

$<$ http://www.senado.gov.br/publicacoes/anais/constituinte/N003.pdf $>$. Acesso em: 25 jan. 2018.

CÂMARA, Alexandre de Freitas. Lições de direito processual civil. vol.1. 24 ed. Rio de Janeiro: Lumen Juris, 2013.

CASSAR, Vólia Bomfim. Direito do trabalho: de acordo com a reforma trabalhista e a MP 808/2017. 15. ed. Método, 2018.

CFMV. Declaração Universal dos Direitos dos Animais. 2017. Disponível em: $<$ http://portal.cfmv.gov.br/portal/uploads/direitos.pdf>. Acesso em: 25 jan. 2018. 
COMPARATO, Fábio Konder. A afirmação histórica dos direitos humanos. 2. ed. São Paulo: Saraiva, 2001.

CRETELLA NETO, José. Curso de direito internacional do meio ambiente. São Paulo: Saraiva, 2012.

DIAS, Edna Cardozo. A tutela jurídica dos animais. Belo Horizonte: Mandamentos, 2000 .

DIAS, Edna Cardoso. A Defesa dos animais e as conquistas legislativas do movimento de proteção animal no Brasil. Revista Brasileira de Direito Animal. v.2, n.2. Salvador: UFBA. 2017. Disponível em:

$<$ https://portalseer.ufba.br/index.php/RBDA/article/view/10297/7357>. Acesso em: 07 mai. 2018.

GODINHO, Maurício. Curso de direito do trabalho. 14. ed. São Paulo: LTr, 2015.

GORDILHO, Heron José de Santana. Direito ambiental pós-moderno. Curitiba: Juruá, 2011 .

Animal abolitionism: Habeas Corpus for great apes. Salvador: EDUFBA, 2017.

HUSEK, Carlos Roberto. Curso de direito internacional público. 3. ed. São Paulo: LTr, 2000.

MAZZUOLI, Valério de Oliveira. Curso de direito internacional público. 8.ed. São Paulo: Revista dos Tribunais, 2014.

MELLO, Celso de Albuquerque. Curso de direito internacional público. Rio de Janeiro: Renovar, 2001.

MENEZES, Wagner. A "soft law" como fonte do direito internacional. Curitiba: Juruá, 2003. 
MINISTÉRIO DAS RELAÇÕES EXTERIORES. Resposta ao pedido de informação.

Resposta obtida pelo portal da informação (https://esic.cgu.gov.br). 25 jan. 2018.

MONCADA, Antonio Cabral de. Curso de direito internacional público. v. 1.

Coimbra: Almedina, 1998.

MOSSIN, Heráclito Antônio. Comentários ao código de processo penal: à luz da doutrina e da jurisprudência. Barueri: Manole, 2005.

MURAL ANIMAL. Direitos dos animais e a declaração que não existe. 2014.

Disponível em: <http://muralanimal.blogspot.com.br/2014/09/direitos-dos-animais-edeclaracao-que.html>. Acesso em: 25 jan. 2018.

NETVET. Declaração Universal dos Direitos dos Animais. 2015. Disponível em: < http://netvet.com.br/post/Declaracao-Universal-dos-Direitos-dos-Animais, $176>$. Acesso em: 25 jan. 2018.

NITERÓI. Decreto n 12567, de 21 de fevereiro de 2017, p. 1. Disponível em: $<$ http://pgm.niteroi.rj.gov.br/legislacao_pmn/2017/DECRETOS/Decn\%2012567\%20Cri a,\%20na\%20Secretaria\%20Executiva,\%20a\%20Coordenadoria\%20Especial\%20Direito\%20d os\%20Animais.pdf>. Acesso em: 25 jan. 2018.

NOUËT, Jean-Claude. Origins of the Universal Declaration of Animal Rights. In: CHAPOUTHIER, Georges; NOUET, Jean-Claude. The Universal Declaration of Animal Rights: Comments and intentions. Paris: Ligue Française des Droits da l'Animal.1998.

NUNES, Rizzato. Manual de introdução ao estudo do direito. 13. ed. São Paulo: Saraiva, 2016. 
ONU. Estatuto da Corte Internacional de Justiça. 26 de junho de 1945, p. 12.

Disponível em: < http://www2.camara.leg.br/atividade-legislativa/comissoes/comissoespermanentes/cdhm/comite-brasileiro-de-direitos-humanos-e-politicaexterna/EstCortIntJust.html>. Acesso em: 25 jan. 2018.

ONU. Re: Esclarecimentos sobre a formalização da Declaração Universal dos

Direitos dos Animais. Resposta obtida pelo e-mail (fernando.brito@ifba.edu.br). 16 jun. 2016.

PIOVESAN, Flávia. Direitos humanos e o direito constitucional internacional. São Paulo: Max Limonad, 2000.

POLÍCIA CIVIL DO ESTADO DE MINAS GERAIS. Resolução Lei n 16.431, de 22 de setembro de 2016, p. 1. Disponível em:

$<$ https://www.jusbrasil.com.br/diarios/54319571/doemg-executivo-24-01-2013-pg-41>. Acesso em: 25 jan. 2018.

RESEK, José Francisco. Direito internacional público: curso elementar. 8.ed. São Paulo: Saraiva, 2000.

VARELLA, Marcelo. D. Direito internacional público. 4. ed. São Paulo: Saraiva, 2012.

SILVA, Tagore Trajano de Almeida. Direito animal e ensino jurídico: formação e autonomia de um saber pós-humanista. Tese (Doutorado em Direito Público) Programa de Pós-graduação em Direito da Universidade Federal da Bahia, 2013. Disponível em: <https://repositorio.ufba.br/ri/handle/ri/15284>. Acesso em: 25 jan. 2018.

SOARES, Guido Fernandes Silva. Direito internacional do meio ambiente: emergência, obrigações e responsabilidades. São Paulo: Atlas, 2001. 


\title{
A POSSE DE ARMAS NUCLEARES POR ESTADOS REVISIONISTAS
}

Filipe Augusto Silva

Universidade de Itaúna

Renata Mantovani de Lima

Universidade de Itaúna

\section{Resumo}

Pretende-se no presente artigo enfrentar a questão da posse de armas nucleares por Estados Revisionistas, e o perigo que isto representa para a ordem internacional contemporânea. Para tanto, discorrer-se-á sobre a Teoria da Dissuasão Nuclear, bem como sobre a redução gradativa e consequente abolição deste tipo de armamento. Após, examinar-se-á os aspectos legais do tema sob o Direito Internacional. Ao final, se apresentará uma estratégia formulada para se lidar com referido problema. A vertente metodológica adotada: jurídico-sociológica; tipo de raciocínio: dialético; tipos metodológicos da pesquisa: histórico-jurídico, jurídicointerpretativo e o jurídico-propositivo.

Palavras-chave: Arma Nuclear, Estado Revisionista, Teoria da Dissuasão Nuclear, Tratado de Não-Proliferação de Armas Nucleares. Ordem Internacional.

\begin{abstract}
Resumen/Résumé
It is intended in this paper to address the issue of the possession of nuclear weapons by Revisionist States, and the danger this poses to the contemporary international order. To do so, the Nuclear Deterrence Theory will be discussed, as well as the gradual reduction and consequent abolition of this type of weaponry. After, the legal aspects of the topic will be examined under the International Law. At the end, a strategy formulated to deal with this problem will be presented. The methodological aspects adopted: juridical-sociological; reasoning type: dialectical; research methodological types: juridical-historical, juridicalinterpretative, juridical-propositional.
\end{abstract}


Keywords/Palabras-claves/Mots-clés: Nuclear Weapon, Revisionist State, Nuclear Deterrence Theory, Treaty on the Non-Proliferation of Nuclear Weapons, International Order.

\section{Introdução}

Desde o momento que foram concebidas e efetivamente utilizadas, as armas nucleares mudaram os rumos da história da humanidade, inaugurando um novo período, a Era Atômica. A partir deste acontecimento, os Estados viram-se diante de um novo problema de proporções globais: o perigo da aniquilação humana através do uso de referido tipo de armamento, tamanho o seu poder destrutivo.

Com a proliferação das armas nucleares após a $2^{\mathrm{a}}$ Guerra Mundial, houve um período de elevada tensão, conhecido como a Guerra Fria, onde o destino da humanidade repousava na manutenção de um equilíbrio precário entre duas potências nuclearmente armadas, a saber, Estados Unidos e a União Soviética, criando-se uma espécie de "balança do terror" no mundo.

Com o fim da Guerra Fria, o problema da proliferação se agravou, tanto que pequenas nações conseguiram obter armamento nuclear e, alguma delas, constituem-se em Estados Revisionistas, ou seja, que estão insatisfeitos com as regras e normas que regem a ordem internacional e a posição eu ocupam nesta seara. O problema é que, referido descontentamento, gera uma situação onde tais países utilizam-se da ameaça de uso de armas nucleares para desafiar o sistema internacional com o fito de modificá-lo.

Dessa forma, nos dias de hoje, instaurou-se uma "tensão nuclear" ainda maior do que aquela da Guerra Fria, onde o equilíbrio precário que existia naquela época, parece ter desaparecido, o que se deu em razão da proliferação de armas nucleares, principalmente para os Estados Revisionistas com pouca proeminência no cenário internacional.

Assim, o objetivo do presente artigo é analisar a questão da posse de armas nucleares pelos Estados Revisionistas, examinando os conceitos da Teoria da Dissuasão Nuclear e da Abolição Nuclear, bem como a legalidade de referido armamento sob o Direito Internacional para, ao final, propor soluções para este problema que desafia a humanidade no século XXI. Servirá como Marco Teórico o seguinte trecho de autoria da francesa Thérèse Delpech:

A era dos pequenos poderes também significa que as nações em questão frequentemente acreditam que não possuem uma participação justa em um determinado sistema internacional. Talvez eles façam tudo o que puderem para mudar isso. Meios pacíficos - incluindo diplomacia violenta, o jeito Norte Coreano - podem ser empregados. Meios não-pacíficos dificilmente podem ser excluídos. A teoria da dissuasão favorece os poderes do status quo, não os poderes insatisfeitos com as limitações impostas a eles pela distribuição existente de poder e armas superiores nas 
mãos de outros. Neste sentido, os anos recentes têm mostrado exemplos perigosos de estratégias assimétricas bem-sucedidas (por exemplo, a Guerra do Líbano de 2006, entre Israel e o Hezbollah). ${ }^{1}$ (DELPECH, 2012, p.112).

No tocante à metodologia, adotar-se-á a vertente metodológica jurídico-sociológica, uma vez que se analisará a questão jurídica das armas nucleares como variável dependente da sociedade. O tipo de raciocínio utilizado será o dialético, pois confrontar-se-á as ideias aparentemente contraditórias da dissuasão nuclear e da abolição nuclear, alcançando-se uma síntese. Por fim, os tipos metodológicos da pesquisa empregados serão o histórico-jurídico, jurídico-interpretativo e o jurídico-propositivo (DIAS; GUSTIN, 2010, p.22-29).

\section{Dissuasão Nuclear e a Prevenção do Uso de Armas de Destruição em Massa}

A Teoria da Dissuasão Nuclear é constituída por vários conceitos e visões distintas. De modo geral, referida teoria tem como escopo “ [...] convencer um potencial adversário que os riscos e custos da ação por ele proposta superam, em muito, qualquer ganho que ele espere talvez alcançar" (BUSH; FELBAB-BROWN; INDYK; O'HANLON; PIFER; POLLACK, 2010, p.1). Assim, a dissuasão nuclear pretende garantir que os países portadores de armas de destruição em massa não irão utilizá-las por receio de igual retaliação nuclear por outros Estados, criando-se uma espécie de "balança de terror" no mundo (WALZER, 2015, p.305/306). Nesse sentido:

Se a bomba atômica puder ser usada sem receio de uma igual retaliação substancial, isto claramente encorajará a agressão. Com muito mais razão, portanto, é que devem ser tomadas todas as medidas necessárias para se assegurar que a posse multilateral da bomba, uma vez que isto se prove inevitável, seja acompanhada por ajustes que garantam, com a maior certeza possível, que o agressor que use a bomba, também a tenha utilizada contra ele.

Se tais ajustem forem feitos, a bomba não pode deixar de ser considerada como um poderoso inibidor da agressão. Faria, relativamente, pouca diferença, caso um poder possuísse mais bombas e estivesse mais bem preparado para resistir às mesmas, do que seu oponente. De toda forma, ele sofreria uma destruição incalculável de vida e propriedade. É certo que existiu, na década de trinta, uma aversão mais profunda e provavelmente mais generalizada à guerra do que em qualquer outra era da história. Sob aquelas circunstâncias, o nascimento de uma nova guerra exigiria uma situação que combinasse ditadores de uma irresponsabilidade singular, com uma noção entre eles e seus militares, que a agressão seria bem-sucedida e barata. A possibilidade de homens irresponsáveis ou desesperados se tornarem governantes de estados poderosos, sob o sistema de políticas internacional existente, não pode ser descartada no futuro. Mas parece ser bem possível apagar a ideia - se não entre governantes

\footnotetext{
1 Tradução nossa.

2 Tradução nossa.
} 
loucos, mas pelo menos entre seus apoiadores militares - de que a agressão será barata. $^{3}$ (BRODIE, 1946, p.61/62).

Infelizmente, enquanto existirem armas nucleares, a Teoria da Dissuasão Nuclear parece ser a política mais sensata a ser utilizada para se lidar com as mesmas, tendo em vista que as alternativas a tal teoria incluem a chantagem, a intimidação, a coerção, bem como o próprio uso de referido armamento (DELPECH, 2012, p.11). A dissuasão:

[...] importa mais às nações dispostas a limitar a intensificação da violência. Concluise, então, que a dissuasão importa mais às democracias adversas-ao-risco, sejam elas Ocidentais, Asiáticas, ou do Oriente Médio. Levou algum tempo para as nações Ocidentais convencerem Moscou que a dissuasão era a melhor política, quando armas nucleares estavam envolvidas. Ainda não é claro hoje se tal tentativa foi plenamente bem-sucedida. No caso da China, a dissuasão significou, por muito tempo, coerção, e talvez ainda signifique atrás de portas fechadas. Como o Paquistão, Irã e Coréia do Norte calculam os custos e benefícios prospectivos, permanece um enigma. ${ }^{4}$ (DELPECH, 2012, p.1, nota de rodapé 3).

Nesse ponto, ressalta-se que há alguns estudiosos ${ }^{5}$ que argumentam que a Teoria da Dissuasão, na verdade, serve como justificativa para a existência e manutenção de armas nucleares. Somado a isso, existe uma confusão analítica advinda da ideia de que a dissuasão nuclear somente merece credibilidade caso se comtemple o uso de fato de armas nucleares. "Como consequência, frequentemente, apenas uma pequena diferença é percebida entre uma doutrina da dissuasão e uma doutrina do uso real. Isto leva à crença que a dissuasão nuclear é inseparável da doutrina do uso, enquanto, na verdade, o propósito da dissuasão é evitar o uso.”6 (DELPECH, 2012, p.11/12).

Um argumento que corrobora a distinção entre a doutrina da dissuasão e a doutrina do uso real, é que, caso alguma arma nuclear eventualmente for utilizada por um país em um ataque, a dissuasão nuclear irá falhar em alcançar seu objetivo, a saber, o de evitar o uso de armamento nuclear. Por isso que é impossível, por uma questão puramente lógica, que tal doutrina contemple em seu âmbito o uso de fato de armas nucleares, pois, uma vez que este cenário se apresente, a mesma terá, ulteriormente, fracassado. É contraditório se condicionar a

\footnotetext{
${ }^{3}$ Idem.

${ }^{4}$ Tradução nossa.

${ }^{5}$ Nesse sentido, ver: OAM, Sue Wareham. Nuclear Deterrence Theory - a Threat to Inflict Terror. In: Flinders Law Journal. Adelaide: Flinders University, 2013, v.15, n.2, pp.257-272.

${ }^{6}$ Tradução nossa.
} 
própria validade e funcionamento de uma teoria à ocorrência de algo que, caso de fato ocorra, a destruirá por completo.

O objetivo da dissuasão nuclear em se evitar o uso de armas nucleares, pode ser confirmado pelo próprio criador de tal teoria, quando o mesmo afirmou que "Até o momento, o principal propósito de nosso estabelecimento militar tem sido vencer guerras. Daqui em diante, seu principal propósito deve ser evitá-las ${ }^{7 ”}$ (BRODIE, 1946, p.62).

É preciso ter em mente que, a partir do momento em que a tecnologia para o desenvolvimento de armas nucleares tornou-se uma realidade, a sua obtenção por outros países era praticamente impossível de se evitar, sendo apenas uma questão de tempo para que isso ocorresse. E, conforme visto, o monopólio deste tipo de armamento tem um grande potencial de fomentar um ânimo agressivo pelo detentor. Assim, acredita-se que a ideia da dissuasão surge do pragmatismo exigido para se lidar com a questão das armas nucleares no cenário internacional.

Portanto, atualmente, considerando-se que a posse de armas nucleares por algumas nações é uma realidade, a dissuasão existe como um meio para se evitar o uso deste tipo de armamento, e não como uma justificativa para mantê-lo. E ainda que se considere a manutenção deste tipo de armamento como um efeito indireto da dissuasão nuclear, isto não tem o condão de descaracterizar o verdadeiro objetivo de tal teoria, uma vez que, conforme visto, apesar de suas várias imperfeições, ainda sim é a melhor alternativa viável atualmente, para que se reduza de maneira considerável a ocorrência de uma guerra nuclear.

\subsection{Política da Dissuasão e Política da Eliminação: relação antagônica ou de interdependência?}

A ideia da dissuasão nuclear pode ser considerada, à primeira vista, como incompatível com a política de eliminação do arsenal nuclear mundial, tendo em vista que aquela, para atingir seu objetivo, exige a manutenção de armas nucleares pelos Estados. No entanto, a partir do momento que a presente questão passe a ser enxergada sob uma perspectiva diferente, percebese que esta suposta contradição é apenas aparente.

Defende-se aqui que a questão das armas nucleares deve ser tratada de forma pragmática. Assim, considerando-se o fato de que a posse deste tipo de armamento é uma realidade, e a sua completa eliminação deve ser realizada de forma conjunta - empreendimento

\footnotetext{
${ }^{7}$ Idem.
} 
este que demandará um longo tempo, tendo em vista as circunstâncias que envolvem o cenário político e as relações internacionais atuais - uma vez que, conforme já demonstrado, a posse unilateral representa uma situação ainda pior que a posse multilateral, acredita-se que a única maneira sensata de se lidar com este quadro, seja através da adoção simultânea das políticas da dissuasão e da eliminação.

Mas como conciliar dois conceitos aparentemente inconciliáveis? Em primeiro lugar, o verdadeiro objetivo da Teoria da Dissuasão deve ser compreendido, a saber, o de impedir o uso de armas nucleares pelos Estados. Em segundo lugar, deve-se ter em mente que as alternativas reais e imediatas à referida teoria, constituem-se em situações muito piores, como, por exemplo, a chantagem e a coerção. Por último, a teoria deve ser vista como uma necessidade temporária à situação internacional contemporânea, ou seja, constitui-se numa teoria fadada à obsolescência, uma vez que se alcance uma alternativa melhor e permanente que, no caso, seria a eliminação do arsenal nuclear por todos os países que os mantém.

Assim, com essas premissas em mente, pode-se afirmar que a Teoria da Dissuasão Nuclear deve ser adotada como uma política de curto prazo, juntamente com uma política de médio e longo prazo, quais sejam, a redução gradativa e completa abolição das armas nucleares. Não se deve descartar ou diminuir a importância da dissuasão no contexto internacional atual. Os críticos desta teoria têm de entender que, o errado, é conceber a política da dissuasão como uma de caráter permanente, que irá reger indefinidamente a ordem internacional. A seguinte diferenciação deve ser feita: entre aqueles que reconhecem a importância contemporânea da dissuasão nuclear, mas que entendem seu caráter estritamente temporário e, entre aqueles que a concebem como uma política permanente, utilizando-se da mesma como justificativa para proliferação de armamento nuclear. Estes últimos, sim, merecem críticas.

Para uma melhor compreensão desta visão, realiza-se a seguinte analogia: todos concordam que a fome é algo terrível que atinge grande parte da população mundial, e que devem ser tomadas todas as medidas para que a mesma seja erradicada o mais rápido possível. Portanto, deve ser adotada uma política para sua eliminação, política esta que, inexoravelmente, será de longo prazo, uma vez que referida situação é muito complexa e levará tempo para que seja resolvida de vez. No entanto, durante o lapso de tempo até a resolução do problema, muitas pessoas pereceriam caso uma medida imediata, não fosse adotada, com o intuito de amenizar a atual situação. Assim, juntamente com a política de erradicação, uma outra, de curto prazo, precisa ser tomada para diminuir os efeitos nefastos da fome. O mesmo raciocínio deve ser aplicado no tocante à questão das armas nucleares. 
Do que adiantaria a adoção unicamente de uma política de curto prazo, com efeitos paliativos, sendo que o problema jamais seria resolvido de maneira definitiva? E de que serviria a adoção exclusiva de uma política de longo prazo, se isso significasse a perda de incontáveis vidas, até a erradicação do problema? Portanto, outra alternativa não resta a não ser concluir que, a relação entre a política da dissuasão nuclear e da eliminação das armas de destruição em massa, é de interdependência, e não de antagonismo. Uma não pode existir sem a outra, dentro do cenário político internacional contemporâneo.

Defender a Teoria da Dissuasão Nuclear não impede que se pregue, ao mesmo tempo, a redução gradativa e consequente abolição das armas de destruição em massa, sendo justamente esta visão a defendida pelo presente trabalho. É essencial que se entenda que não são posicionamentos ideológicos mutuamente excludentes.

Obviamente que, a imediata abolição das armas nucleares, seria o caminho ideal a se seguir. Porém, acreditar que países como China ou Rússia estejam dispostos, num futuro próximo, a concordar com esta política, beira a ingenuidade. O desarmamento mútuo apenas será uma alternativa plausível, caso os Estados decidam trabalhar conjuntamente para atingir este objetivo (WALZER, 2015, p.310). Assim, a eliminação das armas nucleares está irremediavelmente vinculada a um consenso entre as nações neste sentido.

Afirma-se isso pois, a abolição, para funcionar, deve ser completa, visto que a eliminação total por apenas alguns países, levaria a um indesejado monopólio, que tem o condão de ser uma situação ainda pior que a posse multilateral. Portanto:

[...] sem a ameaça de uso, o uso real seria muito mais provável. A eliminação das armas nucleares não melhoraria a política de não-proliferação, mas daria a países como a Coréia do Norte e Irã um perigoso poder de chantagem.

A hostilidade política não é induzida pela inquietação criada por armas nucleares, mas somente o aliviamento da hostilidade política permitiria o desmantelamento de arsenais nucleares. [...].

Com o advento das armas nucleares, a crença não era a de que todas as guerras se tornaram impensáveis, mas que as guerras futuras seriam menos irrestritas. Aqueles que propõem a eliminação deveriam explicar por que as guerras seriam menos irrestritas sem as armas nucleares. Eles deveriam abordar a questão das forças nucleares Chinesas e Russas, ambos países tendo aumentado a proeminência das armas nucleares, a China como um poder em crescimento e a Rússia como um em declínio. Deveriam reconhecer que a ocultação de estoques nucleares seria mais difícil para as democracias do que para as autocracias e que, mesmo se os estoques atuais fossem genuinamente eliminados, novos poderiam ser produzidos durante o curso de um conflito. ${ }^{8}$ (DELPECH, 2012, p.55).

\footnotetext{
${ }^{8}$ Tradução nossa.
} 
Por todo o exposto, conclui-se que a Teoria da Dissuasão Nuclear em si não é o problema, e sim a sua aceitação como uma política permanente para lidar com a questão das armas nucleares. Referida teoria constitui-se numa política de curto prazo com o objetivo de lidar com a atual situação internacional, evitando, ainda que de maneira imperfeita, a eclosão de uma guerra nuclear. Desta forma, a sua adoção deve ser necessariamente acompanhada de uma política de médio a longo prazo, consistente na redução e consequente erradicação conjunta, pelos países, de seus arsenais nucleares.

\subsection{Conceitos atinentes à Teoria da Dissuasão Nuclear}

Desde a sua criação por Bernard Brodie, em 1945, a dissuasão nuclear tem sido bastante estudada, principalmente no período da Guerra Fria, sendo que vários conceitos e entendimentos sobre o tema foram concebidos e revistos, com o objetivo de se acompanhar as constantes mudanças ocorridas no cenário internacional político. Dessa maneira, é necessário que se discorra sobre alguns conceitos que integram a Teoria da Dissuasão Nuclear, para que se possa compreender o seu papel e funcionamento no mundo contemporâneo.

\subsubsection{Dissuasão Estendida e Credibilidade}

A dissuasão estendida pode ser conceituada como a ameaça, implícita ou explícita, de retaliação por parte de um país, contra um adversário, que ataque algum de seus aliados, ou seja, o ataque não precisa ocorrer no território do país retaliante para que haja uma resposta deste último, basta que a agressão tenha como alvo o território de um de seus aliados (MONTGOMERY, 2016, p.2). Assim, referida ideia exige a interação de pelo menos três atores estratégicos distintos: o defensor (o extensor da dissuasão); o desafiador (a figura a ser dissuadida) e; o protegido (o alvo do desafio e a parte a ser defendida) (CRAWFORD, 2009, p.279).

Existem dois tipos de dissuasão estendida: geral e imediata. $\mathrm{Na}$ primeira, há a existência de uma relação de proteção entre defensor e protegido, e o desafiador é dissuadido de coagir este último por medo da resposta do primeiro. Já a segunda espécie ocorre quando a dissuasão estendida geral falha, ou seja, o desafiador passa a coagir o protegido abertamente, e o defensor ameaça, de maneira evidente, intervir na situação. "Se o desafiador recuar por causa 
das ações do defensor, então a dissuasão estendida imediata foi bem-sucedida. Ela falha se, afrontando o defensor, o desafiador ataca o protegido." (CRAWFORD, 2009, p.279/280).

O objetivo de proteção a nações aliadas, preconizado pela dissuasão estendida, produz um efeito de extrema importância: impede que haja a proliferação de armas nucleares para outros países, tendo em vista que, ao contar com o escudo proporcionado pelo país defensor, os Estados protegidos não buscarão adquirir ou desenvolver este tipo de armamento (DELPECH, 2012, p.29).

Um exemplo de que tal efeito funciona, pode ser percebido na postura do Japão contra a introdução, desenvolvimento ou posse de armas nucleares em seu território. $\mathrm{O}$ fato de estar bem próximo da China e, principalmente, da Coréia do Norte, poderia instigar o Japão a produzir armamento nuclear como forma de dissuadir tais nações a atacá-lo. Porém, com a proteção estendida proporcionada pelos Estados Unidos, o Japão se sente seguro o suficiente para, até o presente momento, não se engajar em referida política armamentista nuclear.

Porém, um dos problemas apresentados pela dissuasão estendida, envolve a sua dependência em relação a outro conceito, o da credibilidade, para atingir satisfatoriamente os seus objetivos. A credibilidade é constituída por dois aspectos distintos: capacidade e determinação. "O adversário deve estar convencido que a capacidade do inimigo em agir está lá, fazendo com que os custos sejam maiores que as vantagens em atingir seus objetivos. Ele também deve acreditar na determinação do inimigo: Suas intenções devem ser críveis."10. (DELPECH, 2012, p.45). Faz parte de referido conceito fazer com que o adversário acredite que a retaliação será mais devastadora que o ataque que a provocou.

Assim, principalmente em relação à determinação do país defensor, a ideia da dissuasão estendida é bem menos crível que a da dissuasão propriamente dita, tendo em vista que, constitui-se em tarefa muito difícil, fazer com que um adversário acredite que uma nação esteja verdadeiramente disposta a arriscar a segurança de seu próprio povo e território, em defesa de seus aliados, quando armas nucleares estão envolvidas. Apesar disso, a dissuasão estendida ainda pode ser considerada como um instrumento eficaz no combate ao uso de armamento nuclear pelos Estados.

\footnotetext{
9 Tradução nossa.

10 Tradução nossa.
} 


\subsection{2 (In)Certeza}

O tema revolve em torno da questão de como os líderes das nações interpretam e se portam diante de ameaças. A dissuasão nuclear funcionaria de maneira mais eficiente caso os Estados tivessem certeza da resposta de seus adversários, ou seria melhor que houvesse incerteza sobre a mesma? Em outras palavras, a ambiguidade fortalece ou enfraquece a Teoria da Dissuasão Nuclear (DELPECH, 2012, p.46/47)? Esta questão:

[...] foi calorosamente debatida durante a Guerra Fria. O princípio por trás da ambiguidade é que a dissuasão funciona melhor caso o adversário seja confundido por incertezas na resposta do inimigo, o que frustra o ataque e o planejamento de contingencia. Thomas Schelling pensava que a incerteza, em essência, realmente fortalecia a dissuasão: A ideia é de que um adversário, incerto sobre como seu inimigo poderia responder a uma certa ação, pensaria duas vezes sobre praticar tal ação. [...] Herman Kahn acreditava no oposto: que a dissuasão funcionaria melhor quando o oponente compreendesse completamente as consequências inevitáveis de um ataque. ${ }^{11}$ (DELPECH, 2012, p.47).

É inegável que a incerteza paira sobre o cenário internacional contemporâneo, constituindo-se como um exemplo acurado, as atitudes tomadas pelo líder da Coréia do Norte, Kim Jong-un. Neste caso específico, há incerteza envolvendo tanto as ações do ditador coreano, quanto as respostas às mesmas por parte dos Estados Unidos.

Os constantes testes nucleares realizados pela Coréia do Norte, claramente também tinham como objetivo averiguar até que ponto a política da "Paciência Estratégica", adotada pelo Governo Norte-Americano, suportaria. A incerteza criou uma espécie de "círculo vicioso" entre os países, no qual os Estados Unidos não empreendiam uma resposta mais assertiva frente à incerteza sobre as atitudes do líder Norte-Coreano, e este se aproveitava da própria incerteza emanada por sua figura, para testar a incerteza que possuía em relação a determinação NorteAmericana.

Esse exemplo demonstra que a ambiguidade em algumas situações, ao invés de dissuadir, pode levantar dúvidas sobre a determinação do adversário, incitando, inclusive, uma postura provocativa. Desta forma, suscitar um sentimento de certeza na outra parte é mais seguro em certas ocasiões. Assim:

\footnotetext{
${ }^{11}$ Idem.
} 
Em um mundo onde surpresas estratégicas tendem a se tornarem a regra, ao invés da exceção, a incerteza pode provar ser mais perturbadora para o Ocidente do que para seus potenciais adversários - particularmente se eles estiverem convencidos que as sociedades Ocidentais estão cada vez menos dispostas a lutar. A manipulação do risco, um conceito frequentemente associado com a incerteza, também parece ser melhor entendido (e praticado) hoje pelos líderes da Coréia do Norte e do Irã, do que pelas potências Ocidentais. $^{12}$ (DELPECH, 2012, p.48).

\section{Análise Jurídica da Legalidade das Armas Nucleares sob o Direito Internacional}

A legalidade das armas nucleares, no âmbito do Direito Internacional, pode ser analisada sob diferentes aspectos que vão desde a obtenção, até o uso pelos Estados, de tal armamento. Esta análise inclui o exame legal de referidas armas, sob as normas do Direito Humanitário e de tratados internacionais. Na sequência, realizar-se-á uma breve análise deste tema.

\subsection{A legalidade do uso de Armas Nucleares sob o Direito Internacional Humanitário}

O Direito Internacional Humanitário (DIH) constitui-se num corpo normativo complexo, formado por regras costumeiras, geralmente voltadas à regulamentação da condução das hostilidades na guerra (jus in bello), muitas das quais estão codificadas nas Convenções de Haia e Convenções de Genebra (BURROUGHS; GRANOFF; MOXLEY JUNIOR; 2011, p.609/610). A Corte Internacional de Justiça, em sua Opinião Consultiva sobre a Legalidade da Ameaça ou Uso de Armas Nucleares ${ }^{13}$, concluiu que o uso de tal armamento está sujeito ao DIH e que, de forma geral, seria considerado ilegal sob as normas estabelecidas pelo mesmo (BURROUGHS; GRANOFF; MOXLEY JUNIOR, 2011, p.637). Neste sentido:

Primariamente, dentre as regras do direito internacional humanitário (DIH) está a distinção nos ataques, a qual exige que as partes, em qualquer conflito - internacional ou não-internacional - direcione ataques apenas contra objetivos militares lícitos, sejam pessoas ou objetos. Entretanto, mesmo se o ataque for assim direcionado, a regra da proporcionalidade dita que o dano civil (mortes, ferimentos, dano a objetos civis, ou uma combinação deles) não pode ser excessivo quando comparado com a vantagem militar direta e concreta antecipada. ${ }^{14}$ (BERSAGEL; CASEY-MASLEN; NYSTUEN, 2014, p.2).

\footnotetext{
12 Tradução nossa.

13 Disponível em http://www.icj-cij.org/docket/index.php?p1=3\&p2=4\&k=e1\&p3=4\&case=95. Acesso em 30/04/2017.

14 Tradução nossa.
} 
A regra ou princípio da Discriminação (Distinção) encontra-se positivado no artigo 51 (4) e (5), alínea "a", do Protocolo Adicional I às Convenções de Genebra (CONVENÇÃO DE GENEBRA, 1977), que tratam sobre a proteção da população civil. Este artigo preconiza que são proibidos ataques indiscriminados que, por sua vez, se traduzem naqueles que: não são dirigidos contra um objetivo militar específico; empregam métodos ou meios de combate impossíveis de serem dirigidos contra um objetivo militar específico; empregam métodos ou meios de combate cujos efeitos não seja possível limitar, de acordo com as regras de referido Protocolo Adicional; são realizados através de bombardeio, quaisquer que sejam os métodos ou meios utilizados, direcionados a um ou vários alvos militares, claramente delimitado, situados em uma cidade, um povoado, uma aldeia ou outra área em que haja concentração análoga de pessoas civis ou bens de caráter civil; e que em consequência, em qualquer de tais casos, possam atingir indistintamente objetivos militares e pessoa civis ou, ainda, bens de caráter civil.

Por sua vez, a regra ou princípio da Proporcionalidade, que possui um forte vínculo com o da Discriminação, está estampado também em referido artigo 51, porém no inciso 5, alínea "b". Esta alínea prega que, considerar-se-ão indiscriminados, os ataques quando se pode prever que causarão incidentalmente mortos e ferimentos entre a população civil, ou danos a bens de caráter civil, ou ambas as coisas, e que seriam excessivos em relação à vantagem militar concreta e diretamente prevista.

Obviamente que o uso de armamento nuclear poderia ser analisado através de outros instrumentos normativos, presentes sob a égide do Direito Internacional Humanitário, como, por exemplo, o Estatuto de Roma, que rege o Tribunal Penal Internacional. Entretanto, só com o exame de tais princípios dispostos no Protocolo I Adicional às Convenções de Genebra, já é possível concluir que o uso legal de armas nucleares é impossível, uma vez que não há possibilidade em se limitar os efeitos de um ataque realizado com a utilização de armamento desta natureza.

\subsection{Instrumentos Normativos sobre Não-Proliferação, Desarmamento e Zonas Livres de Armas Nucleares}

Após a Segunda Guerra Mundial, a proliferação de armas nucleares pelo mundo passou a ser uma grande preocupação, tendo em vista seu imenso poder destrutivo. Assim, Estados Unidos, Reino Unido e União Soviética, resolveram negociar o Tratado de Não- 
Proliferação de Armas Nucleares (TNP), que foi aberto a adesões em 1968, entrando em vigor internacional no ano de 1970. Atualmente, 191 países ${ }^{15}$ são parte deste tratado internacional.

O TNP, em seus artigos I e II (ESTADOS UNIDOS; REINO UNIDO; UNIÃO SOVIÉTICA, 1968), preconiza, de forma geral, que os Estados-Parte nuclearmente $\operatorname{armados}^{16}$ se comprometem a não transferir armas nucleares, bem como a não assistir, encorajar ou induzir a sua fabricação ou obtenção pelos Estados-Parte não-nuclearmente armados que, por sua vez, se comprometem a não receber, fabricar ou adquirir este tipo de armamento.

Os artigos IV e V do TNP asseguram o direito do uso pacífico de energia nuclear pelos Estados-Parte, encorajando, neste sentido, a pesquisa e a troca de tecnologias e informações entre os países. Já o artigo VI consagra disposição importantíssima, ao declarar que os EstadosParte se comprometem a engajar em negociações de medidas efetivas para a cessação da corrida armamentista nuclear e para o desarmamento nuclear, assim como de um tratado sobre desarmamento completo e geral, sob estrito e efetivo controle internacional.

O TNP dispõe, ainda, em seu artigo VII, sobre as chamadas "Zonas Livres de Armas Nucleares" (ZLAN). Segundo a Resolução 3472 (B) da Assembleia Geral da ONU (ONU, 1975), referidas zonas possuem dois requisitos mínimos para sua existência: a) a ausência completa de armas nucleares dentro dos limites da zona estabelecida e; b) o estabelecimento de um sistema internacional de verificação e controle para garantir a observância das obrigações pelos Estados-Parte da zona livre de armas nucleares.

Atualmente existem cinco tratados em vigor, estabelecendo ZLAN: 1) Tratado de Tlatelolco para a Proibição de Armas Nucleares na América Latina e no Caribe, de 1967; 2) Tratado de Rarotonga sobre a ZLAN do Pacífico Sul, de 1985; 3) Tratado de Bangkok sobre a ZLAN do Sudeste Asiático, de 1995; 4) Tratado de Pelindaba sobre a ZLAN Africana, de 1996 e; 5) Tratado de Semipalatinsk sobre a ZLAN da Ásia Central, de 2006. Ademais, a Mongólia, em 1992, se autodeclarou um Estado livre de armas nucleares, e o Tratado da Antártida, firmado em 1959, proíbe a presença de armas nucleares na região Antártica (BERSAGEL; CASEYMASLEN; NYSTUEN, 2014, p.11).

Apesar do intuito do TNP em impedir a proliferação de armas nucleares:

\footnotetext{
${ }^{15}$ Informação disponível em http://disarmament.un.org/treaties/t/npt. Acesso em 01/05/2017.

${ }^{16} \mathrm{O}$ artigo IX (3) do TNP esclarece que são considerados "Estados nuclearmente armados" aqueles que fabricaram e explodiram uma arma nuclear ou outro dispositivo nuclear explosivo antes de 01/01/1967. Neste conceito se encaixam China, Estados Unidos, França, Reino Unido e Rússia.
} 
[...] o regime global de não proliferação tem encontrado dificuldades para se consolidar como uma verdadeira norma internacional. Atacados por alguns como uma forma de "apartheid nuclear" e tratado por muitos Estados como uma obsessão por parte de países ricos, as restrições impostas pelo TNP têm funcionado como uma espécie de conjunto de aspirações às quais os países precisam ser coagidos a aceitar e não como uma obrigação legal vinculante. Progressos ilícitos no sentido de produzir armas nucleares têm se revelado difíceis de detectar e interromper, já que seus passos iniciais são idênticos ao desenvolvimento de usos pacíficos da energia nuclear especificamente autorizados pelo TNP. O tratado proibia, mas não evitava, que signatários como Líbia, Síria, Iraque e Irã mantivessem programas nucleares clandestinos em violação das salvaguardas do TNP ou, no caso da Coréia do Norte, se retirasse do tratado em 2003 e testasse e transferisse tecnologia nuclear sem controle internacional.

No caso de um Estado violar ou repudiar termos do TNP, hesitar cumprir suas determinações ou simplesmente se recusar a reconhecer a legitimidade de uma norma internacional de não proliferação, não existe nenhum mecanismo previsto para implementar a aplicação da norma. (KISSINGER, 2015, p.338/339).

Considerando-se a falta de um mecanismo cogente para assegurar o cumprimento do TNP, este tratado depende, em grande parte, para a consecução de seus objetivos, que os países estejam dispostos a cumprir com suas obrigações perante a ordem internacional contemporânea, ou seja, a se submeterem ao status quo, assunto este que será tratado na sequência.

\section{Status quo e sua relação com o surgimento de conflitos entre Estados}

A ideia de status quo está ligada à Teoria da Transição de Poderes que, de forma geral, procura estabelecer uma nova visão do funcionamento das políticas no âmbito mundial. Referida teoria prega que as interações políticas entre os Estados, baseiam-se em seu grau de cometimento com o status quo, que, por sua vez, significa a larga aceitação das normas e regras internacionais existentes (KUGLER; LEMKE; TAMMEN, 2011, p.2).

De acordo com essa teoria, o status quo é mantido pela nação dominante e seus aliados, que estão satisfeitos com o funcionamento da ordem internacional estabelecida. Por outro lado, há Estados que não concordam com referido sistema internacional vigente, estando, portanto, insatisfeitos (Estados Revisionistas), uma vez que não acreditam estar recebendo o que merecem do mesmo (KUGLER; ORGANSKI, 1989, p.173).

A insatisfação com o status quo pode levar a conflitos entre Estados, com o objetivo de se alcançar uma mudança na ordem internacional estabelecida. Obviamente que tal mudança pode ser alcançada através de outros meios, como, por exemplo, através do incremento da população, economia e influência política do país. Porém, existem nações insatisfeitas com o status quo - e que apresentam um grande grau de indiferença às normas internacionais - 
munidas de armas nucleares, que enxergam na ameaça de utilização destes armamentos, uma alternativa para modificar tal situação, como é o caso, por exemplo, da Coréia do Norte.

Não se pretende aqui proceder-se à análise da Teoria da Transição de Poderes, e sim ressaltar que alguns Estados Revisionistas, em menor ou maior grau, não possuem respeito pelas normas que regem o sistema internacional, estando dispostos a se valer da força para alcançar seus objetivos, seja eles quais forem. A insatisfação, portanto, tem o condão de gerar indiferença pelas normas internacionais e levar a conflitos entre nações, ameaçando o status quo.

\subsection{O Problema da Posse de Armas Nucleares por Estados Revisionistas}

Conforme explicado, Estados Revisionistas são aqueles que estão insatisfeitos com o atual sistema internacional (status quo) e o papel que desempenham dentro do mesmo. Este sentimento de insatisfação tem como consequência a manifestação de um sentimento de indiferença, em maior ou menor grau, por parte destes países, pelas regras e normas que regem referida ordem internacional.

Ocorre que, alguns Estados Revisionistas, como Irã, Paquistão e Coréia do Norte, possuem armas nucleares em seus arsenais bélicos, o que, combinado a um acentuado grau de indiferença pelas normas e regras internacionais demonstrado por estes países, pode ser a receita para um desastre de proporções globais.

Frisa-se que o questionamento do status quo não é o problema, uma vez que a ordem internacional está longe de ser perfeita, e o questionamento, que gera o debate entre as nações, tende a levar a melhorias. A mudança e consequente aprimoramento do sistema internacional deve ocorrer através do diálogo democrático entre os Estados, preservando-se, ao mesmo tempo, os fundamentos básicos que regem tal sistema, como, por exemplo, o respeito pelos Direitos Humanos, a cooperação mútua, e a busca e preservação da paz.

O problema é a tentativa de se promover mudanças no status quo através da ameaça, coerção, chantagem e efetivo uso de armas nucleares, o que causaria a completa ruína da atual ordem internacional, junto com os fundamentos básicos que a sustentam.

Na sequência, será analisada a questão da posse e fabricação de armas nucleares por um Estado Revisionista, a saber, Coréia do Norte, tendo em vista o seu extenso histórico de desrespeito por normas internacionais, bem como o seu recente destaque (negativo) na política internacional ao intensificar o risco de uma guerra nuclear através da prática de ações, no mínimo, imprudentes. Além disso, "A nuclearização da Coréia do Norte é, antes de tudo, uma 
crise internacional que pode derrubar a estrutura mundial de controle de armas" ${ }^{17}$ (CHANG, 2009, cap.3).

\subsubsection{Coréia do Norte e seu Papel na Intensificação da Tensão Nuclear Mundial}

A Coréia do Norte possui um passado de rejeição pelas normas internacionais, principalmente no que diz respeito a aquisição, produção e realização de testes de armas nucleares. Apesar de ter aderido ao TNP em 1985, tal país se retirou do mesmo em 2003, alegando a agressividade dos Estados Unidos ${ }^{18}$ como justificativa para sua atitude.

Desde então, a Coréia do Norte já realizou cerca de seis testes nucleares, em completo desrespeito à "Declaração Conjunta da Coréia do Norte e do Sul sobre a Desnuclearização da Península Coreana" (CORÉIA DO NORTE; CORÉIA DO SUL, 1992), em vigor desde 19/02/1992 e ao "Plano de Ação Convencionado entre EUA-RPDC" (CORÉIA DO NORTE; ESTADOS UNIDOS, 1994), assinado em 21/10/1994.

Além da fabricação e dos testes de armas nucleares realizados pela Coréia do Norte, há outro problema que pode ser considerado ainda maior: o comércio de tecnologias nucleares cruciais para outros países (CHANG, 2009, cap. Foreword to the Paperback Edition) o que tem o condão de aumentar a proliferação deste tipo de armamento exponencialmente.

Ademais, dois incidentes provocados pela Coréia do Norte demonstram claramente a total indiferença deste país em relação às normas que regem a ordem internacional vigente. $\mathrm{O}$ primeiro incidente ocorreu no dia 26/03/2010, quando a corveta Sul-Coreana "Cheonan" foi partida em duas por um torpedo e afundou nas águas da ilha de Baengnyeong, matando 46 tripulantes. Uma investigação internacional conjunta foi conduzida pela Coréia do Sul, Estados Unidos, Reino Unido e Suécia, concluindo que o navio havia sido afundado por um torpedo disparado de um submarino Norte-Coreano. No dia 15/05/2010, um navio encontrou no local do incidente, várias partes do torpedo CHT-02D, exportado pela Coréia do Norte (DELPECH, 2012, p.103, nota de rodapé 27).

Já o segundo incidente, ocorrido em 23/11/2010, diz respeito a um bombardeamento, não provocado, realizado pela Coréia do Norte, à ilha Sul-Coreana de Yeonpyeong, onde a Coréia do Sul realizava um exercício militar. Neste ataque, várias pessoas, entre militares e civis, foram mortos ou ficaram feridos.

\footnotetext{
17 Tradução nossa.

18 Notícia disponibilizada em https:/www.theguardian.com/world/2003/jan/10/northkorea1. Acesso em 03/05/2017.
} 
Uma das grandes questões que contribuem para a impunidade, em âmbito internacional, da Coréia do Norte, diz respeito à política ambígua da China ao considerar referido país um problema que deve ser enfrentado em Pequim, e em nenhum outro lugar (DELPECH, 2012, p.105). Ilustrando esta política protetiva Chinesa controversa:

Logo após Pyongyang ter afundado o Cheonan, Kim Jong Il foi para Pequim procurar aconselhamento. Lá, ele foi recebido não como um pária, mas como um interlocutor para preparar a estratégia para as semanas vindouras. Pequim esperou um mês antes de enviar qualquer mensagem para Seul após a catástrofe, revelando onde estava sua simpatia. Quando os resultados da investigação internacional foram revelados, Pyongyang chamou a investigação de "fabricação" e ameaçou uma "guerra total", enquanto a China não se comprometeu, chamando o incidente apenas de "muito infeliz" (uma expressão mais adequada a uma gafe diplomática do que ao assassinato de 46 pessoas) e pedindo "cautela e contenção", algo que seria dificilmente contemplado se 46 marinheiros Chineses fossem mortos durante um ataque por um terceiro (para replicar alguns dos elementos intimamente adversários na relação intercoreana, vamos imaginar que Taiwan tivesse afundado uma embarcação da marinha Chinesa). ${ }^{19}$ (DELPECH, 2012, p.105).

Outro fator crucial que alimenta o sentimento de impunidade Norte-Coreano é a apatia da comunidade internacional perante as suas ações agressivas, principalmente no tocante aos membros permanentes do Conselho de Segurança da ONU. Isto pois, estas nações especificamente, possuem a capacidade de aplicar sanções através da ONU, possuindo, assim, mais poder para restringir suas atitudes nocivas contra a ordem internacional. Nesse sentido:

Nenhuma nação responsável se beneficiaria, em última instância, de uma rápida proliferação e consequente colapso da ordem global. Todos os países têm uma participação no resultado da crise em curso na península Coreana - bem como cada estado falido e grupo terrorista. Tudo está em jogo na Coréia do Norte. Este é o lugar onde o mundo escreve sua história para os próximos cem anos. ${ }^{20}$ (CHANG, 2009, cap.11).

O fato da Coréia do Norte ser um país na posse de armas nucleares, torna qualquer tentativa para conter sua agressividade, seja através do diálogo ou da implementação de sanções, bem mais perigosa para um país que não possui este tipo de armamento. Desta forma, os países nuclearmente armados possuem a capacidade - portanto a responsabilidade - de lidar com este problema, em nome da segurança dos demais Estados e da ordem internacional vigente. Com isto em mente, pode-se afirmar que a "Paciência Estratégica" adotada pelos

\footnotetext{
19 Tradução nossa.

${ }^{20}$ Idem.
} 
Estados-Unidos perante a postura internacional nociva Norte-Coreana, durou muito tempo, concedendo a este último, liberdade para agir da forma que bem entendesse, livre de qualquer sanção significativa, o que incentivou manobras e ações cada vez mais ousadas e perigosas por parte deste Estado.

Recentemente, surgiu a suspeita ${ }^{21}$ de que a Coréia do Norte preparava-se para a realização de um teste nuclear, como parte da celebração de seu feriado nacional, intitulado "Dia do Sol", no dia 15/04/2017. Apesar da suspeita, referida celebração se limitou apenas à exposição do aparato militar Norte-Coreano, incluindo vários mísseis. Ocorre que, no dia seguinte, foi feita a tentativa, fracassada, do lançamento de um míssil balístico.

Esse episódio, juntamente com as habituais ameaças de ataque com armas nucleares feita pelo Governo Norte-Coreano aos Estados Unidos, tem provocado a realização de manobras militares conjuntas entre os Governos Norte-Americano e Sul-Coreano, intensificando, desta maneira, a tensão nuclear no mundo.

Cumpre ressaltar, ainda, que os excessos cometidos pela Coréia do Norte, infelizmente, não se restringem à seara internacional. Uma característica nefasta do Governo Norte-Coreano, traduz-se em sua falta de empatia pelo seu próprio povo. Além de utilizar quase a totalidade da ajuda internacional - pedida para alimentar sua população - para manter seu exército, a Coréia do Norte, através do alívio proporcionado por esta assistência humanitária, aproveita para investir em seu arsenal militar, ao invés de melhorar sua economia e infraestrutura (CHANG, 2009, cap.8). Ou seja, a ajuda humanitária recebida é transformada, pelo Governo Norte-Coreano, numa espécie de tática armamentista, às custas da vida de seus nacionais.

Por fim, deve se mencionar que no começo do ano de 2018, o líder norte-coreano Kim Jong-un propôs o envio de uma delegação para as Olimpíadas de Inverno, a serem sediadas pela Coréia do Sul, demonstrando um raro gesto no sentindo de iniciar negociações com o país vizinho. Esta reaproximação das Coréias possibilitou a realização de uma Cúpula conjunta em abril de 2018, na qual ambos países se comprometeram, dentre outros objetivos, a uma total desnuclearização da península Coreana ${ }^{22}$.

Em 12/06/2018, foi realizada a Cúpula entre Coréia do Norte e Estados Unidos, na qual se reafirmou o compromisso de completa desnuclearização da península Coreana. Estes constituem grandes passos na direção correta, rumo a eliminação de armas nucleares no mundo,

\footnotetext{
${ }^{21}$ Suspeita levantada pelo site: http://38north.org/2017/04/punggyeri041217/. Acesso em 06/05/2017.

${ }^{22}$ Para mais informações acessar: https://www.reuters.com/article/us-northkorea-southkorea/korean-leaders-setdenuclearization-goal-trump-says-will-maintain-pressure-idUSKBN1HX2I6. Acesso em 18/10/2018.
} 
possibilitado pela surpreendente e histórica iniciativa de um Estado Revisionista no sentido de abrir mão de seu arsenal nuclear.

Assim, numa repentina guinada de acontecimentos, a Coréia do Norte decidiu mudar sua postura em relação ao seu armamento nuclear, sendo que esta oportunidade deve servir de exemplo para que todos os países nuclearmente armados comecem a eliminar seus arsenais nucleares, através do engajamento em negociações sérias neste sentido, conforme será devidamente discutido no próximo tópico.

\section{Estratégia proposta para enfrentar a questão da Posse de Armas Nucleares por Estados Revisionistas}

A questão das armas nucleares no mundo não pode ser mais vista e tratada da mesma forma que na época da Guerra Fria. Se antes o equilíbrio era mantido por apenas duas potências, hoje há uma multilateralidade de nações com arsenal nuclear, o que enseja uma adaptação nas estratégias, inclusive da Teoria da Dissuasão Nuclear, para a manutenção do equilíbrio e, consequentemente, da prevenção do uso deste tipo de armamento.

O problema dos Estados Revisionistas com arsenal nuclear, principalmente daqueles de pouca expressividade dentro da ordem internacional, são as suas ações imprevisíveis, que acabam por dificultar em muito a adoção de uma estratégia estável. Estas "pequenas potências" não possuem a mesma noção de limites existente na época da Guerra Fria, portando-se como nações dispostas a arriscar tudo para obter seus objetivos.

Portanto, levando-se em conta este cenário internacional contemporâneo, questionase qual seria uma boa estratégia na qual se apoiar, que mantivesse uma certa estabilidade, com o intuito de se diminuir o risco do uso de armas nucleares por referidos Estados Revisionistas.

Acredita-se que a solução depende de um conjunto de ações a serem tomadas, concomitantemente, pelas potências mundiais nuclearmente armadas. Primeiramente, deve haver um efetivo engajamento em negociações pelos Estados, principalmente pelos nuclearmente armados, no sentido de dar cumprimento àquilo assumido perante o TNP, ou seja, cessar a corrida armamentista e possibilitar o desarmamento nuclear mundial, através de um instrumento internacional e vinculante, com sanções reais a quem o descumprir.

As potências nuclearmente armadas devem dar o exemplo através da diminuição, mesmo que unilateral, de seus arsenais, o que projetará uma imagem positiva, aumentado, assim, o ânimo para a eliminação deste tipo de armamento pelas "pequenas potências" revisionistas. Quando se lida com armas nucleares, a quantidade possuída é praticamente 
irrelevante, uma vez que o uso de apenas uma ogiva, por exemplo, pode arruinar o mais poderoso dos Estados, tamanho seu poder destrutivo (CHANG, 2009, cap.12). Por isso, a diminuição não ameaça a Teoria da Dissuasão Nuclear, nem favorece o monopólio. O que referida diminuição tem o potencial de fomentar é um espírito de boa-vontade e cooperação entre as nações, rumo ao desarmamento nuclear global.

A tentativa de obrigar os pequenos países a se desarmarem sem que as grandes potências façam o mesmo, além de uma atitude hipócrita, tem o condão de causar o efeito inverso desejado. Por isso que o exemplo é importante, e a ação conjunta é essencial.

Em segundo lugar, conforme demonstrada a importância da dissuasão nuclear na prevenção do uso de armas nucleares, alguns dos conceitos contidos no âmbito desta teoria devem ser fortalecidos. A ideia da Certeza, juntamente com a de Credibilidade, tem de ser promovida, através de atitudes assertivas e firmes. Os Estados Revisionistas devem crer nas ações das grandes potências nuclearmente armadas, e terem certeza de que suas atitudes extremistas contra a ordem internacional não permanecerão impunes.

Uma das posturas a serem revistas em prol desta mudança, é a efetiva aplicação de sanções impostas pelo Conselho de Segurança da ONU. Pode-se afirmar que a grande causa do fortalecimento da Incerteza e diminuição da Credibilidade é a adoção da estratégia da ameaça sem concretização. Por isso que as medidas anunciadas para deter ações nocivas à ordem internacional, devem ser necessariamente executadas, fortalecendo, desta maneira, o sentimento de certeza no agente delinquente, de que será punido por suas atitudes, o que fomenta a estabilidade.

Para tanto, a atitude protecionista por parte de certos países, como China e Rússia, deve mudar, principalmente pelo fato de que são eles mesmos que aprovam as sanções, para, logo após, contribuir para o seu não-cumprimento por Estados como Coréia do Norte e Irã (DELPECH, 2012, p.113).

Outro conceito, também ligado à ideia de Certeza e Credibilidade, que deve ser fortalecido, é o da Dissuasão Estendida. Tanto o país protegido, quanto o desafiador, devem ter certeza que o Estado protetor irá agir numa possível crise. A determinação deste último deve ser clara e crível, a ponto de dissuadir a nação desafiadora a atacar, bem como gerar um sentimento de proteção forte o suficiente para dissuadir a nação protegida a adquirir ou fabricar armas nucleares para sua proteção.

Cumpre ressaltar que o fortalecimento da Teoria da Dissuasão e de seus elementos não significa o aumento ou proliferação do arsenal nuclear, como foi devidamente demonstrado anteriormente neste estudo. O que se prega é a adoção de uma política de curto prazo que seja 
efetiva, gerando, desta forma, estabilidade suficiente para que os Estados possam se concentrar no desenvolvimento de uma política de longo prazo, que, no caso, se consubstancia na diminuição gradativa das armas nucleares e posterior desarmamento nuclear global.

Assim, acredita-se que o caminho a se seguir para a estabilização imediata, e futura resolução do problema da posse de armas nucleares por Estados Revisionistas, seja através do comprometimento dos Estados nuclearmente armados em entabular negociações sérias, bem como de tomar atitudes efetivas, em prol do desarmamento mundial gradativo, juntamente com a adoção de uma postura firme e crível, que gere a certeza de retaliação proporcional às atitudes nocivas, envolvendo a ameaça ou o uso de armamento nuclear, contra a ordem internacional.

\section{Conclusões}

Conforme demonstrado ao longo do presente artigo, a posse de armas nucleares por Estados Revisionistas, principalmente por aqueles que apresentam um alto grau de indiferença pelas regras e normas que regem o sistema internacional contemporâneo, constitui-se num dos grandes problemas a serem enfrentados pela humanidade no século XXI.

A insatisfação com o status quo apresentado pelos Estados Revisionistas na posse de armas nucleares, pode estimular a adoção de posturas agressivas e desesperadas por parte dos mesmos, com o intuito de se modificar a ordem internacional, mesmo que seja através da ameaça e da coerção. O status quo deve ser protegido, mas não de mudanças, e sim da obliteração. Em outras palavras, o aprimoramento do sistema internacional deve ser incentivado, mas suas bases fundamentais devem ser necessariamente protegidas da ruína que o uso de uma arma nuclear por um país, poderia ocasionar.

Assim, defendeu-se a importância do papel desempenhado pela Teoria da Dissuasão Nuclear na prevenção do uso de armamento nuclear, e sua adoção como uma política de curto prazo, esclarecendo-se que a mesma não pode ser utilizada como justificativa para a manutenção indefinida e proliferação do arsenal nuclear mundial. Ademais, frisou-se a necessidade da adoção concomitante de uma política de médio a longo prazo, consubstanciada na diminuição gradativa e futura abolição conjunta das armas de destruição em massa.

Como forma de lidar com a questão específica da posse de armas nucleares por Estados Revisionistas, principalmente daqueles que apresentam grande grau de rejeição pelas normas internacionais, como, por exemplo Irã e Paquistão, propôs-se o fortalecimento de elementos da Teoria da Dissuasão Nuclear, a saber, a Certeza, a Credibilidade e a Dissuasão Estendida, como forma de se estabilizar a atual situação de tensão nuclear apresentada, o que proporcionaria um 
cenário onde todas as energias poderiam ser direcionadas ao cumprimento dos compromissos assumidos pelos países perante o TNP.

Dessa forma, dar-se-ia cumprimento à ideia desenvolvida e defendida no presente estudo, traduzida na adoção concomitante de uma política de curto e de médio a longo prazo, baseada na premissa de que a Teoria da Dissuasão Nuclear e a Abolição das armas nucleares, não são concepções mutuamente excludentes, e sim interdependentes.

Portanto, diante de toda a análise desenvolvida, conclui-se que a estabilização da situação atual da posse de armas nucleares por Estados Revisionistas, através do fortalecimento da dissuasão nuclear, é de importância ímpar, porém perde o sentido caso esforços não sejam dedicados, simultaneamente, em prol da redução gradativa deste tipo de armamento, visando a futura eliminação do arsenal nuclear mundial.

\section{Referências bibliográficas}

BERSAGEL, Annie Golden; CASEY-MASLEN, Stuart; NYSTUEN, Gro (orgs.). Nuclear Weapons Under International Law: An Overview. Genebra: Geneva Academy, 2014.

BURROUGHS, John; GRANOFF, Jonathan; MOXLEY JUNIOR, Charles. Nuclear Weapons and Compliance with International Humanitarian Law and the Nuclear Non-Proliferation Treaty. In: Fordham International Law Journal. Berkeley: The Berkeley Electronic Press, 2011, v.34, pp.595-696.

BUSH, Richard; FELBAB-BROWN, Vanda; INDYK, Martin; O`HANLON, Michael; PIFER, Steven; POLLACK, Kenneth. U.S. Nuclear and Extended Deterrence: Considerations and Challenges. In: Arms Control Series. Washington: Brookings, 2010.

CHANG, Gordon. Nuclear Showdown: North Korea Takes on the World. Londres: Cornerstone Digital, 2009.

\section{CONVENÇÃO DE GENEBRA. Protocolo I Adicional às Convenções de Genebra de} 08/06/1977. Disponível em https://ihl databases.icrc.org/applic/ihl/ihl.nsf/INTRO/470?OpenDocument. Acesso em 30/04/2017. 
CORÉIA DO NORTE; CORÉIA DO SUL. Declaração Conjunta da Coréia do Norte e do Sul sobre a Desnuclearização da Península Coreana de 20/01/1992. Disponível em http://www.nti.org/learn/treaties-and-regimes/joint-declaration-south-and-north-koreadenuclearization-korean-peninsula/. Acesso em 03/05/2017.

CORÉIA DO NORTE; ESTADOS UNIDOS. Plano de Ação Convencionado entre EUARPDC de 21/10/1994. Disponível em http://www.nti.org/learn/treaties-and-regimes/us-dprkagreed-framework/. Acesso em 03/05/2017.

CRAWFORD, Timothy. The Endurance of Extended Deterrence: Continuity, Change, and Complexity in Theory and Policy. In: MORGAN, Patrick; PAUL, Thazha; Wirtz, James. Complex Deterrence: Strategy in the Global Age. Chicago: University of Chicago Press, 2009, pp.277-303.

DELPECH, Thérèse. Nuclear Deterrence in the $21^{\text {st }}$ Century: Lessons from the Cold War for a New Era of Strategic Piracy. Santa Monica: RAND Corporation, 2012. Disponível em http://www.rand.org/content/dam/rand/pubs/monographs/2012/RAND_MG1103.pdf. Acesso em 01/04/2017.

DIAS, Maria Tereza Fonseca; GUSTIN, Miracy Barbosa de Sousa. (Re)Pensando a Pesquisa Jurídica: Teoria e Prática. 3ª Ed. Belo Horizonte: Del Rey, 2010.

ESTADOS UNIDOS; REINO UNIDO; UNIÃO SOVIÉTICA. Tratado sobre a NãoProliferação de Armas Nucleares de 01/07/1968. Disponível em http://disarmament.un.org/treaties/t/npt/text. Acesso em 01/05/2017.

KISSINGER, Henry. Ordem Mundial. Rio de Janeiro: Objetiva, 2015.

KUGLER, Jacek; LEMKE, Douglas; TAMMEN, Ronald. Power Transition Theory. Portland: Transresearch Consortium, 2011. Disponível em http://transresearchconsortium.com/power-transistions. Acesso em 14/04/2017. 
KUGLER, Jacek; ORGANSKI, Abramo. The Power Transition: A Retrospective and Prospective Evaluation. In: Handbook of War Studies. Boston: Unwin Hyman, 1989, pp.171-194.

MONTGOMERY, Evan Braden. Extended Deterrence in the Second Nuclear Age: Geopolitics, Proliferation, and the Future of U.S. Security Commitments. Washington: Center for Strategic and Budgetary Assessments (CSBA), 2016.

ONU. Resolução 3472 da Assembleia Geral da ONU de 11/12/1975. Disponível em http://www.un.org/en/ga/search/view_doc.asp?symbol=A/RES/3472(XXX). Acesso em 02/05/2017.

WALZER, Michael. Just and Unjust Wars: a Moral Argument with Historical Illustrations. 5a Ed. Nova York: Basic Books, 2015. 


\title{
CONFLITO INTERNACIONAL ENTRE A BOLÍVIA E O CHILE POR UM ACESSO PLENO E SOBERANO AO OCEANO PACÍFICO PARA A BOLÍVIA
}

\author{
André Vinícius Guimarães de Carvalho \\ Universidad Autónoma de Asunción \\ Paulo Joviniano Álvares dos Prazeres \\ Universidade Católica de Pernambuco
}

\begin{abstract}
Resumo
A importância da mediação e da arbitragem internacional para a solução do conflito entre o Chile e a Bolívia para garantir um acesso soberano da Bolívia ao oceano pacífico, demanda referências legais e que sirvam de base para o início das negociações, visto que, a ação na corte internacional da Haia contempla apenas a obrigatoriedade do Chile negociar com Bolívia, mas, não traz nenhum parâmetro, o que tentamos oferecer neste artigo como base para o início das negociações entre os dois países.
\end{abstract}

Palavras-chave: direito marítimo, acesso soberano ao mar, conflito territorial, Chile x Bolívia, acesso ao mar.

\begin{abstract}
Resumen/Résumé
The importance of mediation and international arbitration for the settlement of the conflict between Chile and Bolivia in order to guarantee Bolivia's sovereign access to the Pacific Ocean requires legal references and serve as a basis for the start of negotiations, since the court action The Hague international agreement contemplates only the obligation of Chile to negotiate with Bolivia, but it does not offer any parameters, which we try to offer in this article as the basis for the beginning of the negotiations between the two countries.
\end{abstract}

Keywords/Palabras-claves/Mots-clés: maritime law, sovereign access to the sea, territorial conflict, Chile $\mathrm{x}$ Bolivia, access to the sea. 


\section{Introdução}

Os conflitos internacionais estão a cada dia em mais pautas, muitas delas políticas, outras econômicas e algumas territoriais, porém, certo é que séculos de guerras e libertação de colônias, acumularam dívidas pesadas para países que ousaram enfrentar pela força, estruturas e governos mais organizados e com alianças mais fortes.

Este é o caso da Bolívia que ao longo da sua colonização, até os processos de independência e consolidação da sua soberania, perdeu mais de 50\% (cinquenta porcento) do seu território, além de se tornar um país mediterrâneo, o que contribuiu fortemente para o seu empobrecimento em relação aos seus vizinhos litorâneos.

A Bolívia perdeu seu acesso soberano ao mar para o Chile na denominada guerra do pacífico há mais de um século, e desde lá não tem conseguido crescer e desenvolver sua economia nos mesmos patamares dos outros países do continente sul-americano, porém, tem estrategicamente e diplomaticamente se posicionado e conquistado espaço e reconhecimento da importância que tal acesso soberano representa para o desenvolvimento do seu povo e o equilíbrio do continente.

Neste conjunto de intervenções políticas e diplomáticas ao longo dos anos, colocou o Chile perante a Corte Internacional na Haia numa situação que, pelos pedidos e precedentes mundiais hodiernos, levarão a obrigatoriedade do Chile em negociar um acesso soberano da Bolívia ao mar, porém, mesmo que saia vencedora no seu pleito, os efeitos continuam inatingíveis e podem se arrastar por décadas até uma solução efetiva para a Bolívia.

O que pretendemos com este trabalho é introduzir caminhos eficazes de resolução de conflitos, através da mediação e arbitragem internacional, sugerindo marcos referenciais que possam nortear o início razoável das tratativas, de forma objetiva e que possa estabelecer um maior equilíbrio e desenvolvimento da região, além de corrigir erros históricos e curar traumas que ultrapassam a questão da soberania plena e adentram a própria alma do povo boliviano, garantindo um acesso soberano da Bolívia ao mar do pacífico e com isso, recompensando o Chile pelos prejuízos financeiros e econômicos, mas, representam além de uma importante contribuição para o resgate social e econômico do vizinho, um grande gesto de democracia.

Com isso, cresce em importância a compreensão dos mecanismos que possam garantir uma intervenção justa e mediada, que não represente a criação de um novo conflito ou a acirramento das diferenças históricas entre os dois povos. 


\section{Breve histórico de como a Bolívia perdeu o seu acesso soberano ao mar}

Os conflitos e hostilidades entre o Chile e a Bolívia em assuntos internacionais não começou, tem origens na declaração da Bolívia como uma nação independente em 1825, quando se torna independente do Império Espanhol e inicia-se o desembarque do capital britânico-chileno com investimentos em território boliviano, sendo o marco inicial a instalação da Empresa Salitreira. Em 1873, incomodados com os promissores negócios, o Congresso boliviano aprovou uma lei taxa a exportação do salitre, gerando um descontentamento dos empresários chilenos, que mobilizaram o Governo Chileno a intervir no problema, dando origem a uma cadeia longa de conflitos e onde um acordo final nunca foi alcançado, colocando no centro das discussões inclusive questões relacionadas à soberania dos territórios de ambos os países em virtude da independência da coroa espanhola no hemisfério.

Na denominada Guerra do Pacífico, como ficou conhecida, a batalha envolvendo de um lado o Chile contra Bolívia e o Peru, isso de 1879 a 1883, e que apesar do curto tempo em relação a outros conflitos no hemisfério, deixou ressentimentos e traumas profundos principalmente para a Bolívia, que em consequência da sua derrota na referida guerra, amargou uma perde significativa de seu território, inclusive $400 \mathrm{~km}$ de faixa litorânea, e o mais grave a partir de então transformou-se num país mediterrâneo, visto que não possui mais um acesso soberano para oceano pacífico.

A Bolívia ainda depois da guerra, perdeu outros territórios: para o Brasil - o Acre, em 1903 - e para o Paraguai - a região do Chaco, em 1935, além de outros para o próprio Chile e a Argentina. A soma total reflete a perda fundamental da soberania territorial boliviana: em 1825, a Bolívia tinha 2,36 milhões de $\mathrm{km} 2$ e atualmente a sua área é um pouco maior que 1 milhão de km2, ou seja, o país perdeu mais da metade de suas terras, em guerras, acordos e negócios com seus vizinhos sul-americanos.

Curiosamente, e numa demonstração clara que essa perda do seu acesso soberano ao mar jamais foi esquecida, é que anualmente o dia 23 de março, é comemorado nacionalmente como o Dia do Mar na Bolívia, desfiles, discurso do presidente, salvas de canhões e parada militar, estão no cronograma, inclusive o desfile da Marinha boliviana.

A atual Constituição boliviana coloca como sendo um dos seus principais objetivos a questão do seu acesso soberano ao mar, e escreveu que "o Estado boliviano declara seu direito irrenunciável ao território que dá acesso ao oceano pacífico e seu espaço marítimo", mas, 
seguindo um viés diplomático, para agregar a simpatia do mundo, acrescentar que isso será feito através de "vias pacíficas".

O Chile argumenta que isso gera um entrave à retomada das relações diplomáticas dos países, paradas desde 1978, e fica fácil entender a dificuldade na solução desse conflito porque, os departamentos ao norte do Chile, exatamente o que seria a área objeto da negociação que garantiria um acesso soberano da Bolívia ao mar, têm a maior renda per capita e IDH - Índice de Desenvolvimento Humano do país graças a exploração do cobre, que responde por metade das exportações chilenas, o Chile também alegar que isso representaria uma perda da sua soberania territorial, além, deste fato transformar a Bolívia em um país competidor com o Chile pelo mercado aberto pelo Pacífico, o que, economicamente e politicamente é uma matéria impensável nos termos atuais do contexto latino-americano. E assim, segue a Bolívia sem um acesso soberano ao mar e sem qualquer perspectiva diplomática e pacífica de negociação por parte do Chile para a solução deste conflito.

\section{Cronologia das tentativas diplomáticas de solução do conflito para uma negociação que outorgue um acesso soberano da Bolívia ao oceano pacífico - CONVEMAR - resoluções 426 de 1979 e 989 de 1989 da OEA e outros documentos diplomáticos em favor da solução do conflito internacional entre o Chile e a Bolívia.}

Em 20 de outubro de 1904, Chile e Bolívia assinam um tratado de paz e amizade. No documento, os novos territórios foram consertados assim que o conflito armado terminou. A Bolívia nesse ato perdeu 400 quilômetros de litoral e 120 mil quilômetros quadrados de território.

Em 1920, a Bolívia faz uma primeira tentativa de uma revisão do tratado do pacífico no perante a chamada a época Liga das Nações, porém, seu pleito não teve uma boa recepção e não prosperou. e só após 30 anos, em 1950, houve uma reaproximação na através de uma troca de notas diplomáticas entre o Chile e a Bolívia para negociar um corredor a norte do porto de Aricá.

Com à assinatura do Pacto de Bogotá em 1948 também denominado "Tratado Americano de Soluções Pacíficas" que teve como objetivo resolver conflitos através da diplomacia.

Tanto o Chile quanto a Bolívia ratificaram o tratado com reservas, porém, a Bolívia rechaçou o texto do artigo VI do documento, que afirma que "tampouco tais procedimentos podem ser aplicados a questões já resolvidas por acordo das partes, por sentença arbitral ou por 
julgamento de um tribunal internacional, ou que sejam regidas por acordos ou tratados em vigor na data da celebração do presente Pacto".

E só após 30 anos, da primeira tentativa de 1920, houve uma reaproximação através de uma troca de notas diplomáticas entre o Chile e a Bolívia em 1950, para negociar um corredor a norte do porto de Arica, uma ação efetivamente proposta graças a adesão dos dois Estados ao referido Pacto de Bogotá.

Em 1962, as relações diplomáticas se rompem após a Bolívia acusar o Chile de desviar o fluxo das águas internacionais do rio Lauca.

Em 1975, o então Presidente Chileno Augusto Pinochet proporcionou juntamente com o Presidente Boliviano Hugo Banzer o denominado "abraço de Charaña" que entraria para história como um evento diplomático sem precedentes nesse conflito secular, durante três anos, as relações diplomáticas entre o Chile e a Bolívia foram retomadas e as embaixadas e consulados em seus respectivos territórios foram restabelecidas, até quando em 1979, um golpe de estado na Bolívia faz com que os ministros dos estrangeiros congelem as trocas diplomáticas com o referido Estado.

Em 1979 a Bolívia garante na denominada "X Assembleia Geral da OEA Organização dos países Americanos, a Resolução no 426, que define a falta de uma saída para o mar como um problema hemisférico. OEA pede uma saída soberana ao mar para Bolívia.

Em 1989 a OEA através da Resolução 989 “Relatório sobre o Problema Marítimo da Bolívia”, assinala em sua parte resolutiva o seguinte:

\footnotetext{
"Reafirmar a importância que tem a solução do problema marítimo da Bolívia em bases que se coadunem com as conveniências recíprocas e os direitos e interesses das Partes em causa, para melhor entendimento, solidariedade e integração do hemisfério, exortando as Partes ao diálogo e deixando aberta a consideração do tema para qualquer dos próximos períodos ordinários de sessões da Assembleia Geral, a pedido de uma das Partes interessadas."
}

Em 1992, o então Presidente da Bolívia Jaime Paz Zamora, assinou com o então Presidente do Peru Alberto Fujimori, um acordo em que a Bolívia obtém uma saída para o Oceano Pacífico pela província de Ilo, denominado de "Tratado de Ilo", no entanto, com a mudança da presidência peruana e algumas dificuldades econômicas e de estratégias militares, esse acordo ainda sequer foi analisado pelo congresso Peruano, o que recentemente foi motivo do cancelamento de viagem do Presidente Evo Morales a Lima. 
Em 2004 na denominada "Cumbre Hemisférica de Monterrey", no México, o então Presidente Mexicano Carlos Mesa afirma a necessidade de resolução do problema boliviano de acesso soberano ao mar.

Em 2006, Evo Morales e Michelle Bachelet estabeleceram uma agenda de 13 pontos onde o tema marítimo é abordado. Significaria um avanço significativo e consolidaria os esforços diplomáticos para manter um diálogo.

Em 2008, a Magna Carta da Bolívia é reformada, incluindo dentro de seus artigos a questão do direito a um acesso soberano ao oceano pacífico, e a partir de 2011 no auge da tensão política, o discurso boliviano endureceu, dado que não viram o progresso nas conversas mantidas entre as chancelarias para a solução efetiva do conflito.

Em 2012, a Bolívia mais uma vez coloca a sua questão de acesso ao mar e renova os pedidos de negociações conforme as resoluções 426 de 1979 e 989 de 1989 da Organização dos Estados Americanos, por conta do Quadragésimo Segundo Período Ordinário de Sessões da Assembléia Geral na cidade de Cochabamba na Bolívia. E na falta de uma posição clara do Chile de negociar, no mesmo ano o Presidente Boliviano Evo Morales anunciou que apresentaria um processo internacional perante a Corte Internacional de Justiça "Tribunal da Haia” na Holanda, o que concretizado com a reclamação formal no dia 24 de abril de 2013.

\section{Do processo na corte internacional de justiça da Haia.}

Resumo extraído dos autos junto ao Tribunal Internacional de Justiça:

“Obligación de negociar el acceso al Océano Pacífico (Bolivia c. Chile)

156. El 24 de abril de 2013, el Estado Plurinacional de Bolivia entabló una demanda contra Chile respecto de una controversia relativa a la "obligación de Chile de negociar con Bolivia de buena fe y de forma efectiva a fin de llegar a un acuerdo que otorgue a Bolivia un acceso pleno y soberano al Océano Pacífico".

157. La demanda de Bolivia incluye un resumen de los hechos -desde la independencia de ese país en 1825 hasta el presente-que, según Bolivia, constituyen "los principales hechos pertinentes en que se fundamenta la reclamación".

158. En la demanda, Bolivia manifiesta que el tema de la controversia radica en: “a) la existencia de la obligación [mencionada precedentemente], b) el incumplimiento de esa obligación por parte de Chile, y c) el deber de Chile de cumplir esa obligación”.

159. Bolivia afirma, entre otras cosas que "más allá de las obligaciones generales que le incumben en virtud del derecho internacional, Chile se ha comprometido, más específicamente por medio de acuerdos, la práctica diplomática y una serie de declaraciones atribuibles a sus representantes de más alto nivel, a negociar el acceso 
soberano de Bolivia al mar". Según Bolivia, "Chile no ha cumplido esa obligación y... niega la existencia de esa obligación".

160. En consecuencia, Bolivia solicitó a la Corte que "falle y declare que:

a) Chile tiene la obligación de negociar con Bolivia a fin de llegar a un acuerdo que otorgue a Bolivia acceso pleno y soberano al Océano Pacífico;

b) Chile no ha cumplido dicha obligación;

c) Chile debe cumplir dicha obligación de buena fe, pronta y formalmente, en un plazo

razonable y de manera efectiva, a fin de otorgar a Bolivia acceso pleno y soberano al Océano Pacífico".

161. Como fundamento de la competencia de la Corte, el demandante invoca el artículo XXXI del Tratado Americano de Soluciones Pacíficas ("Pacto de Bogotá"), de 30 de abril de 1948, del que ambos Estados son partes.

162. Al final de su demanda, Bolivia "se reserva el derecho de solicitar la constitución de un tribunal arbitral de conformidad con la obligación establecida en el artículo XII del Tratado de Paz y Amistad concertado con Chile el 20 de octubre de 1904 y el protocolo de 16 de abril de 1907, a fin de resolver todas las cuestiones que llegaran a suscitarse con motivo del Tratado".

163. Mediante providencia de fecha 18 de junio de 2013, la Corte estableció los días 17 de abril de 2014 y 18 de febrero de 2015 como plazos respectivos para la presentación de la memoria de Bolivia y la contramemoria de Chile. La memoria se presentó dentro del plazo fijado.

164. El 15 de julio de 2014, haciendo referencia al artículo 79, párrafo 1 del Reglamento de la Corte, Chile opuso una excepción preliminar respecto de la competencia de la Corte en la causa. De conformidad con el párrafo 5 de ese mismo artículo, se suspendió el procedimiento sobre el fondo.

165. Mediante providencia de 15 de julio de 2014, el Presidente de la Corte fijó el 14 de noviembre de 2014 como plazo para que Bolivia presentara por escrito sus observaciones respecto de la excepción preliminar opuesta por Chile."

A Corte Internacional de Justiça (CIJ) em setembro de 2015 se declarou competente para examinar a demanda da Bolívia contra o Chile para recuperar uma saída soberana ao mar, perdida após uma guerra do pacífico no fim do século XIX: "A Corte considera que o caso em disputa não foi resolvido (...) nem está sob a jurisdição de acordos ou tratados em vigor".

A Corte rejeitou por 14 votos contra 2 a objeção preliminar sobre a competência da Corte, que havia sido apresentada pelo Chile, com o tribunal afirmando que tem competência na disputa, com base no Pacto de Bogotá: "tem competência com base do artigo 31 do Pacto de Bogotá para entender a solicitação apresentada pelo Estado plurinacional da Bolívia".

Porém, essa decisão da corte ainda não discute diretamente um "eventual direito da Bolívia a uma saída soberana ao mar", mas a existência de uma obrigação de negociar ou de 
não negociar por parte do Chile, sem que a Corte possa se pronunciar a respeito do conteúdo dessa negociação.

A Corte entendeu que "as disposições relevantes do Tratado de paz de 1904 não abordam, nem explícita, nem implicitamente, a questão de se o Chile tem a obrigação de negociar um acesso soberano ao Oceano Pacífico da Bolívia". O processo com essa decisão seguirá para a fase de Julgamento do pleito boliviano.

\section{A importância da mediação e da arbitragem para resolução de conflitos internacionais.}

Na fala de Ban Ki-Moon, Secretário Geral das Nações Unidas, a mediação é um dos métodos mais eficazes para prevenir, gerenciar e resolver conflitos. Para que seja eficaz, entretanto, um processo de mediação exige mais do que a nomeação de uma personalidade eminente para atuar como terceira parte. Com frequência, as partes em conflito precisam ser convencidas sobre os méritos da mediação, e os processos de paz devem contar com um amplo apoio político, técnico e financeiro. Esforços de mediação ad hoc e mal coordenados, mesmo quando empreendidos com a melhor das intenções, não ajudam a atingir o objetivo de alcançar uma paz durável.

As Diretrizes das Nações Unidas para uma mediação eficaz são desenhadas para amparar esforços profissionais e genuínos de mediação pelo mundo. Este breve documento de referência abrange a riqueza de experiências de mediadores que trabalham nos níveis internacional, nacional e local. Ademais, o documento tem por base depoimentos de indivíduos que se beneficiaram de processos exitosos de mediação, bem como daqueles que sofreram com tentativas fracassadas. Embora todas as disputas e os conflitos tenham caráter único e exijam enfoques específicos, há boas práticas que devem informar as abordagens de todos os mediadores. Esta publicação visa auxiliar as partes de um conflito a fortalecer sua compreensão sobre a mediação eficaz, e ajudar os mediadores na maximização de suas chances de sucesso. Recomendo estas Diretrizes a todos aqueles que estiverem engajados em mediação ou interessados nessa ferramenta essencial para a resolução pacífica de disputas e conflitos.

Cabe aqui esclarecer que as funções da Corte Permanente de Arbitragem não estão limitadas à arbitragem, pois também incluem prover outras formas de solução pacífica de controvérsias internacionais, incluindo a mediação, conciliação e outras formas de soluções alternativas de controvérsias. 
A Corte Permanente de Arbitragem, constituída por tratado em 1899, é uma organização intergovernamental que proporciona uma variedade de serviços para a solução de disputas na comunidade internacional.

Destaque-se, a existência de vários meios de solução de conflitos no âmbito do Direito Internacional, ressaltando o meio judiciário da ARBITRAGEM, instituto utilizado desde a Grécia antiga. Assenta-se nos princípios basilares da soberania, do consentimento mútuo e do pacta sunt servanda.

As Conferências de Paz da Haia, de 1899 e 1907, decidiram pela criação de uma "Corte Permanente de Arbitragem" (que na verdade é uma de uma lista permanente de árbitros, indicados pelos Estados, dentre os notórios juristas de Direito Internacional) sediada na Haia, com a finalidade de dirimir os conflitos entre os Estados.

A regra fundamental do procedimento arbitral é o consenso entre os Estados em submeter à controvérsia a arbitragem e aceitar a decisão, que é proferida por um terceiro: o árbitro.

As sentenças arbitrais, normalmente, são cumpridas voluntariamente pelos Estados, tendo em vista a aplicação do princípio pacta sunt servanda, já que de forma livre e soberana, aceitou submeter o litígio à arbitragem. O procedimento inicia-se através da celebração do compromisso arbitral, no qual os Estados irão estabelecer os limites da controvérsia, indicar os árbitros e decidir por outras questões pertinentes ao procedimento arbitral.

Dada a sentença, ela será irrecorrível, sendo passível, unicamente, de recursos de esclarecimento, ou de anulação, na hipótese de constatação de "falta grave do árbitro" (dolo, corrupção, abuso ou desvio de poder).

Existem dois tipos de arbitragens no Direito Internacional: a ARBITRAGEM ESTRANGEIRA, quando resolve um litígio subordinado inteiramente a uma ordem jurídica de um país estrangeiro e a ARBITRAGEM INTERNACIONAL, quando a relação jurídica controvertida envolve mais de uma ordem jurídica.

A lei brasileira da arbitragem (lei n ${ }^{0}$ 9.307/96) não faz distinção entre as arbitragens estrangeira e internacional. Apenas o Capítulo VI (artigos 34 a 40) é dedicado à homologação das sentenças arbitrais proferidas no estrangeiro, para fins de execução pela Justiça Brasileira. $\mathrm{O} \S$ único do art. 34 considera estrangeiro o laudo arbitral produzido fora do território nacional, logo, o local onde foi proferida a decisão lhe caracteriza a nacionalidade. Mas, esta distinção não pode ser confundida com a distinção entre arbitragem internacional e arbitragem interna, não assimilada por este Diploma. 
Este sistema brasileiro é chamado de monista sendo, também, escolhido por outras legislações, como a lei inglesa e a convenção de Nova Iorque (1958). Não sobrevindo esta diferenciação entre as arbitragens, as partes, ao elaborarem a convenção arbitral, deverão verificar se há tratados internacionais com eficácia no ordenamento jurídico interno regulamentando a matéria e, na sua ausência, se a arbitragem será regulamentada de acordo com a lei 9.307/96.

Assim, uma solução que venha através da mediação, ou através da arbitragem, vai demandar além de um enorme esforço diplomático, uma clara compreensão pelas partes dos ganhos e perdas com o processo, de modo a garantir que as ambas se apropriem da dimensão dos prejuízos e benefícios com o processo e como tratar estas questões internamente sobre os vários aspectos: econômico, financeiro, e principalmente o político.

Este conflito secular além das questões econômicas e financeiras, traz um grande peso político para ambos países, principalmente para o Chile, que sem uma estratégia eficiente da mediação, apontará a primeira vista uma perda da sua soberania, tendo reflexos negativos para os atuais governantes, e é sem dúvida, o maior impasse a ser mediado, qual governante chileno terá a coragem de ver associada a sua história a perda de espaço soberano?, o que dependendo da época e alianças políticas, pode representar um forte argumento político para a oposição.

Com isso, estas questões não são apenas importantes, mas, imprescindíveis a uma solução rápida e eficiente para este conflito.

Vale a pena lembrar que a demanda na Corte Internacional é apenas para garantir a obrigatoriedade de uma negociação objetiva e de boa fé, mas, sem parâmetros objetivos, o que pode gerar inúmeras alternativas que contenham a decisão da Haia, porém, que não sejam eficientes e eficazes do ponto de vista que contemple o acesso soberano ao mar pela Bolívia, contribuindo para o acirramento dos ânimos entre os povos e décadas de prolongamento até uma nova decisão internacional da Corte.

\section{Sobre a arbitragem de conflitos na CONVEMAR - convenção das nações unidas sobre o direito do mar:}

Aprovada em 30 de abril de 1982 em Nova Iorque, Estados Unidos e aberta sua assinatura em 10 de dezembro do mesmo ano, em Montego bay, Jamaica, na 182a seção plenária da II Conferência das Nações Unidas sobre o Direito do Mar (CONVEMAR). Entrou em vigor em 16 de novembro de 1994 depois da 60a ratificação por parte da Guiana. 


\title{
"CONVEMAR
}

ARTIGO 124 - Para efeitos da presente Convenção: a) 'Estado sem litoral' significa um Estado que não tenha costa marítima; b) 'Estado de trânsito' significa um Estado com ou sem costa marítima situado entre um Estado sem litoral e o mar, através de cujo território passa o tráfego em trânsito;

ARTIGO 125: Direito de acesso ao mar e a partir do mar e liberdade de trânsito.”

No seu ANEXO VII, a CONVEMAR já traz a arbitragem como uma solução dos conflitos envolvendo o Tratado e as questões relativas ao Direito do Mar.

\begin{abstract}
“ANEXO VII
Arbitragem

Artigo $1 .^{\circ}$ Início do procedimento

Sem prejuízo das disposições da parte XV, qualquer parte numa controvérsia pode submeter a controvérsia ao procedimento de arbitragem previsto no presente anexo, mediante notificação escrita dirigida à outra parte ou partes na controvérsia. A notificação deve ser acompanhada de uma exposição da pretensão e dos motivos em que se fundamenta."
\end{abstract}

Notem que a notificação com base nestes preceitos deve ser fundamentada e ter a exposição objetiva da pretensão, ou seja, até hoje, não existe uma pretensão objetiva e clara da Bolívia em relação a área que ela entenda ser necessária a efetividade do seu pleito.

Por isso, é importante o amadurecimento de qual ponto basal deverá partir as negociações? qual a área territorial mínima que pode ser referência para o início das negociações e mais, qual a justificativa plausível para tal delimitação territorial?

E isto sim, é extremamente importante para o processo de mediação ou mesmo de arbitragem, pois sem uma explicação plausível e justificável do ponto de vista econômico, financeiro, mas, principalmente político, que demonstre claramente que a grandeza do gesto político para o continente e o mundo tem efeitos mais benéficos ao Chile, que simplesmente a visão de perda de território soberano, visto que a Bolívia já goza de livre trânsito ao mar do pacífico, por concessões acordadas ainda nos tratados de paz da guerra do pacífico, e livre trânsito perpétuos, mas, que não representam a soberania territorial para a Bolívia, e principalmente o direito de exploração das riquezas do mar. 


\section{Conclusão}

O conflito envolvendo a Bolívia e o Chile, onde a Bolívia tenta reaver de forma negociada um acesso pleno e soberano ao oceano pacífico pelo território chileno, encontra elementos extremamente complicados, pois envolve o aumento e redução da soberania territorial, revive feridas históricas de guerras, receios de concorrência exploratória e a afetação econômica nas balanças comerciais dos dois países, além das questões políticas que impactam sobremaneira o animus das partes em negociar.

Neste sentido, um clima de paz e serenidade é fundamental para uma solução pacífica, apenas através de uma mediação que possa levar as partes a um entendimento negociado, sem resquícios de históricos, com um pensamento moderno e fraterno, que possa permitir uma ordem global mais justa e solidária conseguirá solucionar de forma pacífica esse conflito.

Entendemos que a mediação inicialmente se mostra mais adequado, visto que permitirá as partes um acordo sem a necessário julgamento, porém, devido aos complexos elementos que envolvem uma decisão desse porte, fatalmente apenas com uma arbitragem se chegará a uma definição concreta do conflito conforme estabelece a própria CONVEMAR, as resoluções da OEA sobre o caso e uma nova visão mundial de acesso soberano e igualitário aos meios e recursos do planeta.

Assim, já que não existe na prática um real pedido relativo a um tamanho de faixa costeira ou valores e outras moedas de negociação, pautamos como um marco razoável para o início das propostas na arbitragem que de acordo com os limites definidos pela própria CONVEMAR que no mínimo se negocie 12 milhas náuticas equivalentes a aproximadamente 22 quilômetros de faixa litorânea, o que garantiria um mínimo de $12 \mathrm{MN}$ de mar territorial e faixa costeira, não sendo estes números limitantes e sim valores mínimos de acordo com o estabelecido nos preceitos do direito ao mar.

Estes números no nosso entendimento, representam uma base sólida para um marco inicial das negociações, visto que, são números já expressos nas convenções e tratados internacionais, bem como, um paradigma do direito marítimo internacional.

Entendemos que 12 milhas náuticas quadradas, 22 quilômetros quadrados de área territorial soberana é um bom marco lógico e que pode ser uma referência para o início das negociações.

Como estes parâmetros são internacionais e aplicáveis a quaisquer países em relação ao direito marítimo internacional, até mesmo do ponto de vista político, é um importante 
argumento para justificar através de uma base legal internacional, uma referência mínima da negociação, estabelecendo a possibilidade eficaz de solução deste conflito secular.

Temos que levar em consideração que do ponto de vista político, é muito mais palatável, usar um argumento de base jurídica, como base para a cessão do território soberano, agregando a isso, a grandeza humanitária e desenvolvimentista do gesto, pois ao conceder acesso soberano da Bolívia ao mar do pacífico, permitirá ao vizinho um maior desenvolvimento e melhoria do povo boliviano sobre todos os aspectos, o que também permitirá além dos ganhos financeiros com tal negociação, o fechamento de feridas históricas entre os dois países e a formação de parcerias importantes para um futuro promissor no continente sul-americano.

É sempre bom lembrar que a Bolívia já foi aceita para integrar o MERCOSUL e o Chile tem excelentes relações comerciais com os países do pacífico e União Europeia, vale ainda lembrar que na guerra do pacífico o apoio fundamental do Chile veio exatamente da Inglaterra que desde aquela época tem seus interesses vinculados aos chilenos.

Sem dúvida a diplomacia e as relações internacionais terão grande desafio para uma solução negociada ou arbitrada diante de um continente sul-americano vivenciando tantas instabilidades de ordem política e econômica.

É fundamental a habilidade diplomática no desfecho deste conflito, que envolve questões históricas e marcos significativos de hostilidades e, portanto, é imprescindível que as estratégias e respostas a todas estas questões acima referenciadas sejam respondidas e sustentáveis pelas partes.

Evitando o prolongamento do conflito e acirramento das questões históricas de casos de hostilidades que envolvem chilenos e bolivianos.

Quando apontamos a questão da referência mínima para as negociações, isso não significa que esta seja um limitador, mas, apenas um ponto de partida lógico e com grande base de justificativa legal, porém, entendemos que as compensações financeiras ao Chile não devem da mesma forma se limitarem a recursos como numa mera compra e venda de terreno, e devem envolver o desenvolvimento forte e promissor de atividades conjuntas, que envolvam tanto a exploração do solo e subsolo, bem como, das próprias riquezas marítimas, proporcionando aos dois países um aumento potencial da parceria territorial e comercial, ampliando o acesso aos mercados comuns.

Com isso, deve o Chile ter de forma muito clara a exposição das vantagens que a Bolívia pode proporcionar em contrapartida com a cessão do território de forma soberana.

É extremamente importante que as proposições e demandas de cada parte fiquem expostas de forma clara e plausível sob os aspectos econômico, financeiro e político, sendo 
estas demandas objeto de um estudo mais aprofundado que envolva a esfera econômica e comercial do Chile e da Bolívia e todo o contexto da ampliação dessas parcerias e mercados.

\section{Referências bibliográficas}

GOUVÊA, Carina. Bolívia x Chile e o acesso soberano ao mar: um conto inacabado. Disponível em: < https://carinagouvea25.jusbrasil.com.br/artigos/ 111915149/bolivia-X-chile-e-o-acesso-soberano-ao-mar-um-conto-inacabado $>$. Acesso em: 05 de março de 2018.

ROMANO, Rogério Tadeu. O Conflito entre o Chile e a Bolívia. Disponível em: $<$ https://jus.com.br/artigos/65301/o-conflito-entre-o-chile-e-a-bolivia $>$. Acesso em: 05 de março de 2018.

GONIADIS, Max. Chile e Bolívia estão a um passo de travarem uma guerra sem precedentes. Disponível em: < https://br.blastingnews.com/mundo/2017/07/chile-e-boliviaestao-a-um-passo-de-travarem-uma-guerra-sem-precedentes-001841335.html $>$. Acesso: 05 de março de 2018.

FARINELLI, Victor. Chile e Bolívia, um conflito a ponto de sair de controle. Disponível em: < http://www.vermelho.org.br/noticia/299240-7> . Acesso em: 05 de março de 2018.

BBC. A disputa de mais de um século da Bolívia com o Chile por uma saída ao mar. Disponível em: < https://g1.globo.com/mundo/noticia/a-disputa-de-mais-de-um-seculoda-bolivia-com-o-chile-por-uma-saida-ao-mar.ghtml> . Acesso em: 05 de março de 2018.

FERRER, Isabel. Chile e Bolívia revivem em Haia seu conflito por uma saída para o mar. Disponível em:

$<$ https://brasil.elpais.com/brasil/2015/05/04/internacional/1430744745_182951.html> Acesso em: 08 de março de 2018. 
MARTON, Fábio. Guerra do Pacífico: Como a Bolívia perdeu o mar. Disponível em:

$<$ https://aventurasnahistoria.uol.com.br/noticias/guerras/guerra-do-pacifico-o-martirio-dabolivia.phtml> . Acesso em: 08 de março de 2018.

GOUVERNEUR, Cédric. A Bolívia de olho no mar. Disponível em:

$<$ https://diplomatique.org.br/a-bolivia-de-olho-no-mar/> . Acesso em: 10 de março de 2018.

TURRER, Rodrigo. Em Haia, Bolívia mantém esperança de acesso ao mar. Disponível:

$<$ http://internacional.estadao.com.br/noticias/geral,em-haia-bolivia-mantem-esperanca-deacesso-ao-mar,70002212717> . Acesso em: 13 de março de 2018.

REUTERS. Evo Morales vai a Haia para forçar Chile a dar acesso ao mar à

Bolívia. Disponível em: < https://g1.globo.com/mundo/noticia/morales-vai-a-haia-paraforcar-chile-a-dar-acesso-ao-mar-a-bolivia.ghtml> . Acesso em: 15 de março de 2018.

CUÉ, Carlos E. Tensão entre Chile e Peru por seu apoio a saída ao mar de Bolívia. Disponível em:< https://brasil.elpais.com/brasil/2015/06/25/internacional/1435258387_909240.html> Acesso em: 27 de março de 2018.

PASEIRO, Laura Becquer. Bolívia e Chile à espera da decisão sobre o mar. Disponível em: $<$ http://www.prensalatina.com.br/index.php?o=rn\&id=15173\&SEO=bolivia-e-chile-a-esperada-decisao-sobre-o-mar> . Acesso em: 27 de março de 2018.

FARIA, Súsan. Bolívia luta por uma saída pelo mar. Disponível em: < http://embassybrasilia. com.br/site/bolivia-luta-por-uma-saida-pelo-mar/> . Acesso em: 29 de março de 2018. 


\title{
DELIMITAÇÃO MARÍTIMA NO MAR NEGRO NOS TERMOS DA CONVENÇÃO DAS NAÇÕES UNIDAS SOBRE O DIREITO DO MAR
}

\author{
Flávia Fagundes Carvalho de Oliveira \\ Escola Superior Dom Hélder Câmara - ESDHC \\ Cristiane Araújo Mendonça Saliba \\ Escola Superior Dom Hélder Câmara - ESDHC
}

\begin{abstract}
Resumo
A Corte Internacional de Justiça foi chamada para resolver o conflito sobre delimitação de uma única fronteira marítima entre plataforma continental e zona econômica exclusiva envolvendo Romênia e Ucrânia no Mar Negro, que são partes da Convenção das Nações Unidas sobre o Direito do Mar. A Convenção estabelece estrutura normativa para gerir espaços oceânicos, suas formas de usar e recursos disponíveis. Discorreremos ainda sobre a metodologia de delimitação das três fases, conhecida como abordagem da equidistância/circunstâncias relevantes, que se mostrou uma forma precisa para estabelecer delimitações proporcionais. Esta foi endossada em diversas decisões posteriores pelos órgãos internacionais previstos na CNUDM.
\end{abstract}

Palavras-Chave: Convenção das Nações Unidas sobre Direito do Mar, caso Romênia versus Ucrânia, Plataforma Continental, Zona Econômica Exclusiva.

\begin{abstract}
Resumen/Résumé
The International Court of Justice has been called upon to resolve the dispute over the delimitation of a single maritime border between the continental shelf and the exclusive economic zone involving Romania and Ukraine in the Black Sea, which are parties to the United Nations Convention on the Law of the Sea. We will also discuss the three-phase delimitation methodology, known as the equidistance / relevant circumstances approximation, which has proved to be a precise way of establishing proportional delimitations. This has been approved in several subsequent decisions of international bodies under UNCLOS.
\end{abstract}

Keywords/Palabras-claves/Mots-clés: United Nations Convention on the Law of the Sea, Case of Romania versus Ukraine, Continental Shelf, Exclusive Economic Zone. 


\section{Introdução}

Recentemente, a Corte Internacional de Justiça foi chamada para estabelecer uma única fronteira marítima delimitando ${ }^{1}$ a plataforma continental e a zona econômica exclusiva entre Romênia e Ucrânia no Mar Negro. Ambas são partes da Convenção das Nações Unidas sobre o Direito do Mar e, na ocasião, discordavam sobre a fronteira marítima a ser estabelecida.

Nesta perspectiva, a finalidade precípua do presente artigo é refletir sobre a Convenção do Direito do Mar no que diz respeito aos espaços marítimos delimitados em seu texto. Para isso, pretende-se estudar o caso acima mencionado aplicando a Convenção Internacional supramencionada.

O Direito do Mar solidifica-se atualmente como ramo do Direito de fundamental importância, pois contém as normas que disciplinam o mar territorial, zona contígua, zona econômica exclusiva, plataforma continental e alto mar, além de estabelecer a estrutura que normatiza os espaços oceânicos, os recursos disponíveis, dentre outros aspectos de fundamental importância para a manutenção da vida e subsistência econômica.

A Convenção das Nações Unidas sobre o Direito do Mar (UN, 1982), comumente denominada CNUDM, foi uma grande inovação que contribuiu para o complexo Direito do Mar. As negociações para conclusão da Convenção ocorreram durante mais de dez anos, onde, finalmente, fora concluída em 10 de dezembro de 1982, em Montego Bay, Jamaica.

Esta Convenção tem como um dos principais pontos o fornecimento de regras para a proteção dos interesses estratégicos dos Estados no exercício de sua soberania, em um espírito de compreensão e cooperação mútuas, para todas questões que envolvem o Direito do Mar.

A instituição de diretrizes e mecanismos de soluções de conflitos e a demarcação definitiva dos novos limites dos espaços marítimos foram as maiores inovações trazidas pela Convenção de Montego Bay.

Entretanto, mesmo depois de ser o instrumento com o maior número de Estados que a ratificou, o tema Direito do Mar é pouco explorado, principalmente pela dimensão de sua importância, e, muitas vezes deixado de lado nas pesquisas das universidades e pelos órgãos brasileiros.

Neste sentido, para realização do presente trabalho recorre-se à pesquisa bibliográfica em doutrinas jurídicas, revistas e na fonte principal da pesquisa, qual seja, Convenção das Nações Unidas sobre Direito do Mar. Por ora, não se propõe-se esgotar o tema proposto, e sim,

\footnotetext{
${ }^{1}$ Delimitação: Traçado de uma fronteira marítima entre dois ou mais países.
} 
refletir e buscar respostas para melhor aplicação das disposições da Convenção, tendo em vista a importância dos mares e oceanos para a humanidade.

\section{Direito do Mar}

\subsection{Convenção das Nações Unidas sobre Direito do Mar}

Conhecida internacionalmente como United Nations Convention on the Law of the Sea (UNCLOS), a Convenção das Nações Unidas sobre o Direito do Mar (CNUDM - UN, 1982), é um tratado realizado pela Organização das Nações Unidas, em dezembro de 1982, na cidade de Montego Bay, Jamaica. A celebração do referido acordo tem como objetivo codificar conceitos instituídos no direito internacional costumeiro.

A presente convenção dispõe de instrumentos responsáveis para delimitação dos espaços marítimos definidos em seu texto, tais como, o mar territorial, a zona contígua, a zona econômica exclusiva, a plataforma continental, o alto mar e outros não menos importantes, espaços até então, regulamentados por normas de caráter costumeiro. Além do mais, dentre sua determinação mais importante foi a instituição de normas sobre jurisdição, soberania, direitos e obrigações.

Como marco fundamental para a proteção dos mares e oceanos, o presente acordo também normatiza como serão realizadas a utilização dos espaços, tais como o tráfego marítimo, o sobrevôo, a navegação, a conservação, a exploração de recursos e a pesca.

Hodiernamente, de acordo com informações do site do Tribunal Internacional do Direito do Mar, existem 167 Estados Partes da presente Convenção, incluindo 166 membros e uma organização internacional, a Comunidade Europeia. A denominada Convenção dos Mares contém 320 artigos e nove anexos, dentre eles está à criação do Tribunal Internacional do Direito do Mar, que prevê mecanismos para a solução das controvérsias.

As negociações para essa Convenção foram iniciadas em 1958, com a elaboração de quatro Convenções separadas. A segunda Conferência, em 1960, com o intuito de novas tentativas de negociações, não obteve êxito.

Somente em 1973, a Assembleia Geral da ONU decidiu convocar a $3^{\text {a }}$ Conferência sobre o Direito do Mar, em Montego Bay, Jamaica, negociações que perduraram aproximadamente dez anos; participaram da conferência mais de 160 Estados e a abertura para assinaturas deu-se em 1982. Até hoje, o presente acordo distingue por ser um instrumento internacional que conta com maior número de Estados signatários. 
Portanto, no site do Ministério do Meio Ambiente (MMA, 2016), está bem claro e definido o conceito e a importância da Convenção, que é:

(...) estabelecer um novo regime legal abrangente para os mares e oceanos e, no que concerne às questões ambientais, estabelecer regras práticas relativas aos padrões ambientais, assim como o cumprimento dos dispositivos que regulamentam a poluição do meio ambiente marinho; promover a utilização eqüitativa e eficiente dos recursos naturais, a conservação dos recursos vivos e o estudo, a proteção e a preservação do meio marinho.

\section{Espaços marítimos definidos na CNUDM}

Mais de trinta anos após a sua abertura para assinatura e vinte anos após a sua entrada em vigor, a CNUDM continua a fornecer uma resposta eficaz, abrangente e global no quadro jurídico internacional para os oceanos e mares.

De grande relevância para um novo ramo do Direito, a Convenção das Nações Unidas sobre o Direito do Mar instituiu um marco jurídico importantíssimo para os Estados signatários, deu ensejo para compreensão sobre a delimitação dos espaços para utilização e exploração do mar, conforme se verá a seguir.

\subsection{O conceito de mar territorial}

A Convenção das Nações Unidas sobre o Direito do Mar estabelece que a soberania do Estado costeiro se estende além do seu território e das suas águas interiores e, no caso de Estado arquipélago, das suas águas arquipelágicas, a uma zona de mar adjacente designada pelo nome de mar territorial (Art. 02 - UN, 1982).

Ainda de acordo com a Convenção do Mar, todo Estado tem o direito de fixar a largura do seu mar territorial até um limite que não ultrapasse 12 milhas marítimas, medidas a partir de linhas de base determinadas de conformidade com a presente Convenção(Art. 03 - UM, 1982).

Logo, o artigo 17 do supõe (UN, 1982): salvo disposição em contrário da presente Convenção, que os navios de qualquer Estado, costeiro ou sem litoral, gozarão do direito de passagem inocente pelo mar territorial.

O direito de passagem inocente no espaço denominado mar territorial como uma salvaguarda fundamental, segundo artigo 18 (UN, 1982), pode ocorrer apenas com a finalidade de: (i) atravessar esse mar sem penetrar nas águas interiores nem fazer escala num ancoradouro 
ou instalação portuária situada fora das águas interiores; e (ii) dirigir-se para as águas interiores ou delas sair ou fazer escala num desses ancoradouros ou instalações portuárias.

Ademais, conforme o artigo 18, a CNUDM, dispõe que a passagem deverá ser contínua e rápida. Contudo, com relação a passagem entende-se somente o parar e o fundear, inclusive apenas na medida em que aquelas ações constituam incidentes comuns de navegação, ou seja, impostos por motivos de força maior ou por dificuldade grave ou tenham por fim prestar auxílio a pessoas, navios ou aeronaves em perigo ou em dificuldade grave (UN, 1982).

Todavia a passagem não será considerada inocente, quando for prejudicial à paz, à boa ordem ou à segurança do Estado costeiro. Assim, a passagem inocente pelo mar territorial deverá realizar-se de acordo com a Convenção, tomando medidas necessárias para obstar quaisquer passagens que tenham fins não pacíficos.

\subsection{O conceito de zona econômica exclusiva}

A CNUDM determinou direitos em uma faixa marítima designada de zona econômica exclusiva, com benefícios para os Estados costeiros com relação aos recursos vivos e não vivos, dentre outros.

Para tanto, a zona econômica exclusiva compreende uma faixa de terra e a coluna d'água que se estende de doze a 200 milhas marítimas, também contadas a partir das linhas de base que servem para medir a largura do mar territorial.

Nos termos do artigo 56 da CNUDM, na delimitação da zona econômica exclusiva, o Estado costeiro tem (UN, 1982):

b) direitos de soberania para fins de exploração e aproveitamento, conservação e gestão dos recursos naturais, vivos ou não vivos das águas sobrejacentes ao leito do mar, do leito do mar e seu subsolo, e no que se refere a outras atividades com vista à exploração e aproveitamento da zona para fins econômicos, como a produção de energia a partir da água, das correntes e dos ventos;

c) jurisdição, de conformidade com as disposições pertinentes da presente Convenção, no que se refere a:

i) colocação e utilização de ilhas artificiais, instalações e estruturas;

ii) investigação cientifica marinha;

iii) proteção e preservação do meio marinho;

Pode-se considerar que a zona econômica exclusiva é de relevante importância para os Estados, visto que, com os avanços tecnológicos e científicos, compreendeu-se que o espaço 
é riquíssimo em potencialidades de exploração econômica e fundamental para a subsistência energética, alimentar e biológica.

Dessa forma, favorece para avultar os horizontes marinhos pra além do mar territorial como uma área para o exercício de prerrogativas necessárias à exploração dos recursos nele presentes.

\title{
3.3 O conceito de plataforma continental
}

A Plataforma continental é a prorrogação natural do solo mar adentro, até o limite do talude continental. A Convenção sobre Direito do Mar, artigo 77 (UN, 1982), parágrafo primeiro, estabelece o direito do Estado costeiro sobre a plataforma continental:

ARTIGO 77

Direitos do Estado costeiro sobre a plataforma continental

1. O Estado costeiro exerce os direitos de soberania sobre a plataforma continental para efeitos de exploração e aproveitamento dos seus recursos naturais.

Somente o Estado costeiro poderá explorar e aproveitar os recursos disponíveis na plataforma continental, exceto quanto o próprio Estado consentir, ou seja, somente podem ser explorados pelo Estado costeiro ou sobre seu consentimento (UN, 1982):

Os direitos a que se refere o parágrafo $1^{\circ}$, são exclusivos no sentido de que, se o Estado costeiro não explora a plataforma continental ou não aproveita os recursos naturais da mesma, ninguém pode empreender estas atividades sem o expresso consentimento desse Estado.

O conceito de plataforma continental está disposto no artigo 76(UN, 1982), parágrafo primeiro:

\begin{abstract}
A plataforma continental de um Estado costeiro compreende o leito e o subsolo das áreas submarinas que se estendem além do seu mar territorial, em toda a extensão do prolongamento natural do seu território terrestre, até ao bordo exterior da margem continental, ou até uma distância de 200 milhas marítimas das linhas de base a partir das quais se mede a largura do mar territorial, nos casos em que o bordo exterior da margem continental não atinja essa distância.
\end{abstract}

Ressalta-se que a água que encobre a plataforma continental possui farta vida marinha e considerável parte da pesca mundial se realiza nesta zona. Além disso, é nela que se encontra 
a grande parte da produção a nível mundial de petróleo e gás originárias das rochas que se encontram submersas.

Segundo a Convenção (UN, 1982), o Estado costeiro também exerce jurisdição sobre as ilhas artificiais, as instalações e as estruturas sobre a plataforma continental, conforme artigo 80 c/c 60; as atividades de perfuração, art. 81; a colocação de cabos e dutos, art. 79; a pesquisa marinha científica, art. 238; e a proteção e preservação ambiental, art. 208.

Todavia, a CNUDM, de modo específico, permitiu que os Estados costeiros que pretendessem delimitar a sua plataforma continental além das 200 milhas náuticas, até um limite de 350 milhas, das linhas de base sob as quais o mar territorial é medido, poderiam submeter os dados e informações relevantes à Comissão sobre Limites da Plataforma Continental CLPC, que é órgão avaliador da CNUDM.

\section{$3.4 \mathrm{O}$ conceito de alto mar}

O alto-mar compreende as regiões que ultrapassam o limite da zona econômica exclusiva dos Estados. Não é determinado por uma extensão territorial, como as demais, mas compreende toda a porção além das margens legais de determinação dos espaços jurídicos.

O alto-mar não é um espaço determinado para o uso de um país específico, o que torna inviável quaisquer possibilidade de exercício de jurisdição, sendo de uso comum das comunidades internacionais. Nestes termos, aduz o artigo 89 da Convenção: "nenhum Estado pode legitimamente pretender submeter qualquer parte do alto mar à sua soberania" (UN, 1982).

Assegura MENEZES (2015 p.115):

(...) antes do regime de Montego Bay, o alto-mar era tudo o que se estendia além do mar territorial, mas, com o disciplinamento da zona econômica exclusiva, suas dimensões foram relativamente diminuídas, não obstante a perda geográfica tenha afetado seu princípio fundamental consuetudinariamente arraigado da liberdade do alto-mar.

Por sua vez, é no alto-mar que não existe qualquer possibilidade de soberania. Assim, conclui MENEZES (2015 p.115) que o alto-mar é, portanto, um espaço coletivo comum, no qual todos os Estados têm direitos absolutamente iguais e onde não podem invocar qualquer direito preferencial que não esteja consagrado na Convenção. 
Pelo contrário, no espaço do alto-mar, os Estados têm uma carta de direitos e são coletivamente sujeitos a obrigações ligadas a uma dimensão universalista da sociedade humana, devendo sempre ser utilizado para fins pacíficos.

\section{Corte Internacional de Justiça e o Direito do Mar}

Os mares e oceanos fornecem vitais recursos para sobrevivência humana, além de terem papel fundamental na regulação do clima, na segurança alimentar, fornecendo subsistência para milhões de pessoas, fontes de energia, meios de transporte, e desempenham um papel central nas culturas de muitas comunidades costeiras. Portanto, são muito importantes para o desenvolvimento econômico e social dos Estados e pode ajudar na erradicação da desnutrição, no alívio da pobreza e no aumento do nível de vida.

No entanto, os benefícios e as oportunidades que os oceanos podem fornecer a curto e longos prazos estão subordinados a geri-los de forma sustentável e equitativa.

Trata-se de uma tarefa muito desafiadora considerando que os oceanos e seus recursos continuam sob crescente atividade humana insustentável, tanto no mar como em terra, incluindo a pesca excessiva e ilegal, não declarada e não regulamentada, a poluição, mudanças climáticas e os impactos da acidificação dos oceanos, destruição dos habitats marinhos e extração insustentável de não-vivos, recursos marinhos, para citar apenas alguns. Além disso, disputas marítimas e atividades criminosas no mar também afetam direta e indiretamente.

Em contrapartida, a Convenção de Montego Bay regula e determina os limites da soberania e jurisdição, bem como consolida princípios costumeiros, os quais deverão ser observados pelos Estados na utilização conjunta dos mares e oceanos, na tentativa de aplacar problemas distintos relacionados ao Direito do Mar.

Além disso, a CNUDM estabelece mecanismos para solução de controvérsias, alargando seu alcance normativo, como os Tribunais Internacionais para julgamento dos conflitos relacionados ao tema; uma vez que a Convenção tem efeito de tratado internacional e o conteúdo normativo dos seus dispositivos tem caráter declaratório e propositivo. Nesta esteira, leciona MENEZES (2014, p.505):

Cabe esclarecer que, embora o texto goze do efeito de qualquer tratado internacional conforme prescrito pela Convenção de Viena Sobre Direito dos Tratados, o conteúdo normativo de certos dispositivos em seu bojo tem caráter declaratório e propositivo; ainda, o fato de não permitir reservas, senão aquelas previstas na própria Convenção alargam, em análise, seu alcance normativo. 
Não há dúvida de que uma aplicação eficaz da CNUDM contribuirá para o estabelecimento de uma ordem econômica internacional justa e equitativa, principalmente no que diz respeito aos mecanismos de soluções de conflitos, com a criação do Tribunal Internacional do Mar, uma vez que existem diversas disputas travadas por Estados partes da Convenção dos mares, conforme estudo de caso entre Romênia e Ucrânia, exposto na presente pesquisa.

Assim, qualquer controvérsia relativa à interpretação ou à aplicação da CNUDM, será submetida, a pedido de qualquer das partes na disputa, à corte ou tribunal que tenha jurisdição. Neste sentido, o artigo 287 dispõe sobre a escolha do procedimento para solução da controvérsia a serem adotados, conforme a seguir (UN, 1982):

\section{ARTIGO 287}

Escolha do procedimento

1. Um Estado ao assinar ou ratificar a presente Convenção ou a ela aderir, ou em qualquer momento ulterior, pode escolher livremente, por meio de declaração escrita, um ou mais dos seguintes meios para a solução das controvérsias relativas à interpretação ou aplicação da presente Convenção:

a) o Tribunal Internacional do Direito do Mar, estabelecido de conformidade com o Anexo VI;

b) a Corte Internacional de Justiça;

c) um tribunal arbitral constituído de conformidade com o Anexo VII;

d) um tribunal arbitral especial constituído de conformidade com o Anexo VIII, para uma ou mais das categorias de controvérsias especificadas no referido Anexo.

No caso Romênia x Ucrânia, o artigo 4 (h) do ACORDO ADICIONAL, instrumento estabelecido pelas partes em 1997, previa que, caso os Estados não encontrassem uma solução para o estabelecimento de uma única fronteira marítima entre eles em um período razoável não superior a dois anos, o litígio seria levado à Corte Internacional de Justiça, a pedido de qualquer das partes (UN, 1982):

\section{ARTIGO 36}

1. A competência da Corte abrange todas as questões que as partes lhe submetam, bem como todos os assuntos especialmente previstos na Carta das Nações Unidas ou em tratados e convenções em vigor.

2. Os Estados, partes do presente Estatuto, poderão, em qualquer momento, declarar que reconhecem como obrigatória, ipso facto e sem acordos especiais, em relação a qualquer outro Estado que aceite a mesma obrigação, a jurisdição da Corte em todas as controvérsias de ordem jurídica que tenham por objeto:

a) a interpretação de um tratado;

b) qualquer ponto de direito internacional; 
c) a existência de qualquer fato que, se verificado, constituiria violação de um compromisso internacional;

d) a natureza ou extensão da reparação devida pela ruptura de um compromisso internacional.

Assim, a Corte Internacional de Justiça que é o principal órgão judiciário da Organização das Nações Unidas tem o papel precípuo de solucionar, em concordância com o Direito Internacional, todas as disputas legais a ela submetidas, além de oferecer pareceres consultivos sobre questões legais apresentadas por órgãos autorizados da ONU e outras agências especializadas.

\section{Delimitação marítima no Mar Negro nos termos da CNUDM}

Em 3 de Fevereiro de 2009, a Corte Internacional de Justiça emitiu decisão no Processo sobre Delimitação Marítima no Mar Negro (ITLOS, 2012).

A Romênia, em 02 de junho de 1997, sustenta ter assinado um TRATADO DE RELAÇÕES DE COOPERAÇÃO E BOA VIZINHANÇA COM A UCRÂNIA, e um ACORDO ADICIONAL em que os dois Países se comprometeram a encontrar uma solução para o estabelecimento de uma única fronteira marítima entre ambos no Mar Negro, com a finalidade de delimitar a plataforma continental e as zonas econômicas exclusivas pertencentes a eles.

O TRATADO DE RELAÇÕES DE COOPERAÇÃO E BOA VIZINHANÇA, bem como o ACORDO ADICIONAL entraram e vigor no dia 22 de Outubro de 1997.

Conforme mencionado alhures, caso os Estados não encontrassem uma solução para o estabelecimento de uma única fronteira marítima entre eles em um período razoável de dois anos, o litígio seria levado, a pedido de qualquer das partes, à Corte Internacional de Justiça.

À época, Romênia afirma que as negociações foram inconclusivas e, neste sentido, apresentou petição à jurisdição da Corte Internacional de Justiça, em 2004, solicitando o estabelecimento de uma única fronteira marítima delimitando a plataforma continental e a zona econômica exclusiva entre os dois países no Mar Negro (CEDIN, 2016).

A Corte Internacional de Justiça foi chamada para pronunciar-se sobre o tema, no entanto, ainda não havia a metodologia moderna das três fases, conhecida por abordagem da equidistância/circunstância relevante que em 2009, foi aplicada na decisão do Processo do Mar Negro. 
Assim, embora a CIJ já tivesse se manifestado diversas vezes sobre o assunto antes de 2009, nos casos El Salvador v. Honduras (1992); Dinamarca v. Noruega (Jan Mayen) (1993); Guiné-Bissau v. Senegal (1995), Qatar v. Bahrain (2001); Camarões v. Nigéria (2002); e Nicarágua v. Honduras (2007), havia apenas a aplicação de partes da metodologia que seria consolidada no famoso caso discutido neste artigo.

$\mathrm{Na}$ verdade, tais decisões serviram de base para o pensamento maior a respeito da temática, no sentido de buscar, aprofundar e encontrar uma metodologia precisa, como a que foi aplicada no caso ora em análise, em 2009, como veremos a seguir.

Cabe ressaltar que esta decisão simbolizou um divisor de águas com relação à metodologia aplicada em delimitações marítimas, tanto que após esta decisão, ela foi endossada pelo Tribunal Internacional de Justiça nos casos Bangladesh v. Myanmar (2012), Nicarágua v. Colômbia (2012) e no processo Peru v. Chile (2014). Além de ter sido também utilizada pelo Tribunal Arbitral no processo Bangladesh v. Índia (2014).

Como se viu, pode-se concluir que os principais órgãos de resolução de controvérsias previstos na Convenção das Nações Unidas sobre o Direito do Mar têm aplicado a abordagem das três fases, com sucesso.

No caso analisado neste artigo, sobre o conhecido e importante Processo do Mar Negro, há, portanto, um conflito a ser dirimido, pois Tanto a Romênia como a Ucrânia, que são partes da CNUDM, discordam sobre o curso da fronteira marítima a ser estabelecido e, em particular, sobre a Ilha das Serpentes.

Esta ilha consiste num aspecto relevante que influenciará a metodologia aplicada para a delimitação, pois o elevado marítimo que se situa na parte norte-ocidental do Mar Negro, a cerca de 20 milhas náuticas a leste do delta do Danúbio poderá causar desproporções na divisão.

Dessa forma, quando chamada para delimitar a plataforma continental ou a zona econômica exclusiva, ou para determinar uma única linha de fixação de limites entre os Estados, a Corte procede em etapas definidas, a supracitada metodologia de abordagem da equidistância/circunstância, uma vez que a metodologia utilizada será conforme as disposições da presente Convenção sobre o Direito do Mar (UN, 1982).

Neste sentido, a Corte, em primeiro lugar, estabelece uma linha de delimitação provisória ou linha mediana entre as costas adjacentes ${ }^{2}$ ou costas opostas que estão em causa.

\footnotetext{
${ }^{2}$ Costas adjacentes: costas que são uma ao lado da outra e partilham uma fronteira terrestre; costas que não são contíguas, mas que, no entanto, se projetam na mesma direção, também são chamadas de adjacentes.
} 
Dessa forma, uma linha de equidistância ${ }^{3}$ provisória será desenhada no meio entre as costas vizinhas, tanto se forem adjacentes ou situadas de frente. Para tanto, são utilizados pontos físicos de base ao longo da linha denominada baixa-mar das costas.

Para determinação da segunda etapa, a Corte considerará as circunstâncias relevantes. Tais circunstâncias são obstáculos físicos que teriam porventura efeito de distorção na divisão, que no caso do Mar Negro, se traduz com a existência da Ilha das Serpentes, que é um fator de suma relevância que poderá causar desproporções. A existência de uma ilha no alvo da delimitação é um aspecto de relevância de aspecto físico que poderia influenciar a proporção da divisão.

Há ilhas significativas, com maior ponderação e ilhas menos significativos, logicamente, com menor ponderação. A Ilha das Serpentes é um fator relevante de maior consideração. Há ainda, neste método, de se observar as concavidades das costas. No caso das concavidades irregulares, elas poderiam "beliscar” ou cortar a área marítima de um Estado. No caso do Mar Negro, não há a presença de concavidades.

Assim, primeiro, há de se estabelecer a linha de equidistância provisória, para somente depois passar à análise da existência de fatores que exigem a adaptação ou mudança da linha de equidistância provisória, que são na prática as circunstâncias relevantes supracitadas, com a finalidade de alcançar um resultado mais equitativo.

Assim dispõem os artigos 74, que trata da delimitação da zona econômica exclusiva, e 83, sobre a delimitação da plataforma continental da Convenção de Montego Bay, em que o curso da linha final deve resultar, sempre, em uma solução equitativa (UN, 1982):

\begin{abstract}
ARTIGO 74
Delimitação da zona econômica exclusiva entre Estados com costas adjacentes ou situadas frente a frente 1. A delimitação da zona econômica exclusiva entre Estados com costas adjacentes ou situadas frente a frente deve ser feita por acordo, de conformidade com o direito internacional, a que se faz referência no artigo 38 do Estatuto da Corte Internacional de Justiça, a fim de se chegar a uma solução equitativa.
\end{abstract}

\title{
ARTIGO 83
}

Delimitação da plataforma continental entre Estados com costas adjacentes ou situadas frente a frente 1. A delimitação da plataforma continental entre Estados com costas adjacentes ou situadas frente a frente deve ser feita por acordo, de conformidade com o direito internacional a que se faz referência no artigo 38 do Estatuto da Corte Internacional de Justiça, a fim de se chegar a uma solução equitativa.

\footnotetext{
${ }^{3}$ Equidistância significa que a fronteira marítima deve encontrar-se a uma distância igual entre os Estados-partes a uma disputa.
} 
Finalmente, e em uma terceira fase, a Corte verificará se a linha provisória não leva, tal como se apresenta, a um resultado desigual em razão de qualquer desproporção acentuada entre as partes determinadas para cada Estado. Neste caso, analisar-se-á a proporção dos respectivos comprimentos costeiros e a relação entre a zona marítima relevante de cada Estado com referência à linha de delimitação.

Assim, uma verificação final para um resultado equitativo implica uma confirmação de que nenhuma grande desproporcionalidade das áreas marítimas é evidente, em comparação com a proporção dos comprimentos costeiros.

No caso do Mar Negro, sobre a decisão de 2009, também foram cumpridos as três etapas da metodologia supracitada. Tal metodologia é de suma importância, pois o processo confirmou a abordagem das três fases da abordagem da equidistância/circunstâncias relevantes.

O caso em questão foi tão relevante que o Tribunal confirmou que a metodologia foi consolidada e aprovada no sentido de dar uma solução equitativa ao caso, constituindo o princípio diretivo primordial de qualquer delimitação marítima, conforme consagrado nos artigos 74 e 83 da Constituição dos Mares - CNUDM (UN, 1982).

Portanto, segundo determinações da Convenção de Montego Bay, em 3 de Fevereiro de 2009, a CIJ proferiu o seu acórdão na Delimitação do caso do Mar Negro.

\section{Considerações finais}

A CNUDM trouxe uma importante contribuição ao definir as zonas marítimas, entre elas, a soberania e a jurisdição ao explorar recursos naturais vivos e não vivos. Ela trouxe estabilidade nas relações internacionais, bem como mecanismos eficientes de solução de controvérsias, como se viu a partir do caso relacionado em Romênia e Ucrânia levado à Corte Internacional de Justiça para a delimitação do mar territorial e da zona econômica exclusiva entre os opostos e adjacentes Estados, no Mar Negro.

A Corte, por sua vez, a partir da metodologia das três fases conseguiu dirimir o conflito entre Romênia e Ucrânia ao aplicar a forma precisa de delimitação: linha provisória, observação dos aspectos relevantes como a Ilha das Serpentes e, finalmente, a delimitação equitativa. Destarte, em 2009, a Corte emitiu decisão, por unanimidade, acerca do caso sobre Delimitação Marítima no Mar Negro (CEDIN, 2016).

Assim, a Convenção se configura num instrumento de aplicabilidade do Direito do Mar de suma importância, mas pouco estudado e explorado, servindo como vasto espaço para futuros estudos. 
Conclui-se que, antes do advento da Convenção das Nações Unidas sobre o Direito do Mar, os Estados viviam sob conflitos de vários tipos com relação à ausência de um instrumento eficaz que delimitasse os espaços marítimos.

\section{Referências bibliográficas}

\section{CENTRO DE ESTUDOS EM DIREITO E NEGÓCIOS - CEDIN. Delimitação Marítima no}

Mar Negro. Disponível em <http://www.cedin.com.br/wp-content/uploads/2014/08/CasosContenciosos-2009-Delimita\%C3\%A7\%C3\%A3o-Mar\%C3\%ADtima-do-Mar-NegroRom\%C3\%AAnia-v.-Ucr\%C3\%A2nia-Ra\%C3\%ADssa.pdf>. Acesso em 05/12/2016.

INTERNATIONAL TRIBUNAL FOR THE LAW OF THE SEA - ITLOS. Reports of Judgments, Advisory Opinions and Orders. The "ARA Libertad" case (Argentina v. Ghana). List of cases: n. 20, Provisional Measures. 2012. Disponível em $<$ https://www.itlos.org/fileadmin/itlos/documents/cases/case_no.20/C20_Order_15_12_2012. pdf>. Acesso em 29/06/2016.

MENEZES, Wagner. O Direito do Mar. Fundação Alexandre de Gusmão, Brasília; 2015.

Reflexões sobre a Convenção do Direito do Mar. Fundação Alexandre de Gusmão, Brasília; 2014.

\section{MINISTÉRIO DO MEIO AMBIENTE - MMA. Direito do Mar: Convenção das Nações}

Unidas sobre o Direito do Mar (UNCLOS). Disponível em:

$<$ http://www.mma.gov.br/assuntos-internacionais/temas-multilaterais/item/885-direito-domar>. Acesso em 29/06/2016.

UNITED NATIONS - UN. United Nations Convention on the Law of the Sea. Montego Bay, Jamaica. 1982. Disponível em <https://treaties.un.org/doc/Treaties/1994/11 /19941116\%2005-26\%20AM/Ch_XXI_06p.pdf > . Acesso em 21/10/2018. 


\section{LA GOBERNANZA GLOBAL DE LOS CAMBIOS CLIMÁTICOS Y EL ROL DE LOS GOBIERNOS SUBNACIONALES}

Fernando Rei

Universidade Católica de Santos

Mariângela Mendes Lomba Pinho

Universidade Católica de Santos

\section{Resumen}

Los nuevos problemas ambientales mundiales, particularmente el cambio climático, han desafiado al sistema internacional a adoptar medidas efectivas para enfrentar este problema, a riesgo de agravar los impactos sociales, económicos, políticos y ambientales resultantes, incorporando una nueva forma de gobernanza ambiental global: el papel de los gobiernos subnacionales. El artículo sugiere un concepto de paradiplomacia ambiental y explora algunas de las actividades de la Red de Gobiernos Regionales para el Desarrollo Sostenible (nrg4SD). $\mathrm{El}$ artículo reconoce que, como ejemplo de paradiplomacia ambiental, esta red es relevante en la participación de los gobiernos subnacionales en la gobernanza del cambio climático.

Palabras-clave: Gobernanza global; cambio climático; paradiplomacia; nrg4SD; Regions Adapt.

\section{Abstract/Resumen/Résumé}

The emerging global environmental issues, particularly climate change, have been challenging the international system to adopt effective measures to face this problem, at the risk of aggravating the resulting social, economic, political and environmental impacts, incorporating a new form of global environmental governance: the role of subnational governments. The article suggests a concept for environmental paradiplomacy and it explores some of the activities of the Networkf of Regional Governments for Sustainable Development (nrg4SD). The article finds that, as an example of environmental paradiplomacy, this network is relevant in the participation of subnational governments in the governance of climate change.

Keywords/Palabras-claves/Mots-clés: global governance, climate change, paradiplomacy, $\operatorname{nrg} 4 \mathrm{SD}$. 


\section{Introducción}

Una marca de los primeros años del nuevo milenio es que los diversos y complejos problemas ambientales globales, sean a partir de la visión de los gobiernos o de la misma sociedad, vienen retando al sistema internacional a adoptar medidas más efectivas y capaces de atajar con eficiencia a estos problemas, so pena de agravar los impactos sociales, económicos, políticos y ambientales. Y si esos problemas globales hacían parte exclusiva de la agenda internacional de los Estados, en las dos últimas tres lustros nuevos actores de la sociedad internacional, sean del sector privado y de la sociedad civil, sean de otras esferas de gobierno, reclaman su inserción en nuevos modelos de gobernanza, a partir de una nueva relación de compromiso generado por una amplitud del concepto de responsabilidad socio ambiental global multinivel y por el reconocimiento de que esos problemas reclaman una respuesta más cercana a los intereses del ciudadano y de la gestión de los territorios.

En la primera década del nuevo milenio las actividades internacionales de los gobiernos subnacionales ${ }^{1}$ vienen siendo objeto de creciente participación política y de interés académico, incluso en Brasil. Es cierto que las razones de los gobiernos subnacionales no coinciden necesariamente para fomentar y avanzar en esta agenda de compromisos, pero aunque no exista una absoluta identidad de motivos, se reconoce que su implicación en los asuntos amplios que abordan el desarrollo sostenible, especialmente en el régimen internacional de cambios climáticos, representa ya una nueva dinámica, un auténtico y legítimo cambio en la dinámica y en el futuro de las relaciones internacionales con reflejos en los estudios del derecho internacional público.

El objetivo de este trabajo es, a partir de la asunción de compromisos de responsabilidad socio ambiental por parte de los gobiernos subnacionales, explorar la inserción y el papel de esos gobiernos y sus redes de trabajo en el desarrollo del regímenes internacionales, en particular del régimen internacional de los cambios climáticos, con énfasis en la labor de la Red de Gobiernos Regionales para el Desarrollo Sostenible (nrg4SD).que cumplió este año su $15^{\circ}$ aniversario. En este sentido la metodología observada buscó en la literatura especializada la discusión sobre el fenómeno de la paradiplomacia ambiental y, como un estudio de caso, identificó la documentación pertinente en el ámbito del régimen y en particular en el ámbito de nrg4SD. Para cumplir el objetivo propuesto, este material se compone de tres secciones. La primera analiza las principales características de esta rama del Derecho,

\footnotetext{
${ }^{1}$ En términos jurídicos, se trata de la división administrativa y política que media entre el nivel federal y el nivel municipal.
} 
el derecho ambiental internacional -su necesidad y el papel de los actores no estatales, especialmente de los gobiernos subnacionales, en la construcción de una gobernanza climática global. Para hacer más evidente este hecho, la segunda sección se dedica a la presentación de la labor de nrg4SD en la nueva realidad paradiplomática y las iniciativas en curso y finalmente la última sección contiene conclusiones.

\section{Nuevos actores internacionales}

Los tres lustros del nuevo milenio presentan una serie de hechos y de incertidumbres que demandan a la sociedad internacional nuevos desafíos y retos a hacer frente, que para resolverlos, o mismo comprenderlos, hace falta valerse de alguna creatividad y suponer que las soluciones y compromisos sólo son posibles y viables si pensados de una manera responsable, integrada, solidaria y multilateral.

Esta necesidad de búsqueda de una cooperación más responsable también hace que el mundo sea más interdependiente que antes, lo que confirma una nueva lógica del poder en las relaciones internacionales (ANDONOVA et al., 2009; BULKELEY y NEWELL, 2010). En otras palabras, los problemas generales del medio ambiente sólo pueden avanzar hacia soluciones satisfactorias si pensadas, estructuradas, negociadas y reguladas con la percepción de la importancia de creciente del papel desempeñado por agentes nuevos en el escenario internacional (REI y GRANZIERA, 2014).

Los nuevos problemas ambientales globales son verdaderamente un desafío al orden internacional vigente, que se muestra innúmeras veces incapaz en adoptar medidas eficaces para hacer frente a estos problemas con carácter urgente, asumiendo en realidad el riesgo de agravar los impactos sociales, económicos, políticos y ambientales que puedan resultar de su incapacidad de hacerles frente y por consiguiente de cuestionar al orden que ahí está.

Es cierto que el Derecho, por mano del derecho ambiental internacional, busca enfrentar a estos problemas de manera innovadora y pragmática, fomentando la incorporación de una nueva forma de gobernanza ambiental a nivel mundial a partir de medidas llevadas a cabo por nuevos actores para hacer frente a los problemas ambientales (BODANSKY et al., 2008). Entre estos actores y nueva forma, los gobiernos subnacionales y sus redes horizontales de las acciones y sus inserciones en el escenario de la toma de decisiones (HAPPAERTS et al., 2010).

Se puede afirmar que la suma de nuevos actores a la comunidad internacional está directamente asociada a dos fenómenos destacados del siglo XX: el proceso de globalización y 
la urgencia de los problemas ambientales globales, como los cambios climáticos. Con relación al último fenómeno, el agravamiento y la intensidad de eventos extremos del cambio climático a lo largo de los últimos 20 años han reforzado el carácter global de este fenómeno, aunque irónicamente algunos aún no crean el en fenómeno y propongan la retirada de su país del Acuerdo de Paris.

Más, las actuales formas de producción y consumo, como causas antrópicas del cambio climático, se expanden por todo el globo; impactos graves que afectan a todos los niveles de la comunidad (tanto a nivel local como global) en sus distintas modalidades, ambiental, social, económica y política (MATEO, 1992). Estas son las razones por las que la labor en comprometerse y enfrentar los problemas ambientales globales se ha convertido en un reto para otros atores internacionales, públicos y privados.

A nivel internacional, la respuesta diplomática tradicional a la problemática de los cambios climáticos la ha aportado el régimen jurídico específico -un conjunto de reglas, instituciones y medidas de mitigación para luchar contra las emisiones de gases de efecto invernadero (GEI), así como las adaptaciones para gestionar sus impactos de forma anticipada sobre la base de tres tratados: Convención Marco de Naciones Unidas sobre el Cambio Climático (UNFCCC), el Protocolo de Kioto y el Acuerdo de Paris.

\subsection{El Acuerdo de Paris}

El Acuerdo de Paris representa la respuesta global posible en estos momentos al reto del cambio climático, con el fin de mantener el calentamiento del planeta por debajo del $2^{\circ} \mathrm{C} \mathrm{y}$ redoblar los esfuerzos para limitar el aumento de la temperatura al $1,5^{\circ} \mathrm{C}$. Ofrece un marco global más justo, equilibrado y posiblemente duradero para apoyar los esfuerzos de todos los países y de los nuevos actores internacionales frente al cambio climático, sin olvidar el contexto de la erradicación de la pobreza y el hambre, y por la promoción del desarrollo sostenible.

La lucha contra el cambio climático hará que se lleven a cabo acciones a gran escala, por ciudades grandes y pequeñas, regiones, el sector privado, organizaciones públicas y privadas, y hasta por los ciudadanos. Este hecho queda establecido en el Acuerdo de París sobre el Cambio Climático con su fuerte enfoque hacia la acción de los "actores que no son Partes". 
En este sentido, el Acuerdo ${ }^{2}$ dispone:

\begin{abstract}
"V. Interesados que no son Partes:
134. Acoge con satisfacción los esfuerzos de todos los interesados que no son Partes, incluidos los de la sociedad civil, el sector privado, las instituciones financieras, las ciudades y otras autoridades subnacionales, para hacer frente al cambio climático y adoptar medidas de respuesta;

135. Invita a los interesados que no son Partes mencionados en el párrafo 134 supra a que acrecienten sus esfuerzos y apoyen las medidas destinadas a reducir las emisiones y/o a aumentar la resiliencia y disminuir la vulnerabilidad a los efectos adversos del cambio climático, y a que den a conocer esos esfuerzos a través de la plataforma de la Zona de los Actores No Estatales para la Acción Climática [...];”
\end{abstract}

A partir de la dinámica de conferencias anuales, en noviembre de 2017 tuvo lugar en Bonn la vigésimo tercera sesión de la Conferencia de las Partes (COP 23) y la segunda sesión de la conferencia de las Partes del Acuerdo de París (CMA 2).

La conferencia puso de manifiesto cómo el mundo está avanzando para la implementación del Acuerdo de París y cómo se mantiene vivo un espíritu constructivo de diálogo y cooperación multilateral frente al cambio climático, con la imprescindible participación de los nuevos actores internacionales.

\title{
2.2 Gobernanza ambiental global
}

Es cierto que la sociedad internacional ha afrontado históricamente los problemas globales multilaterales mediante acuerdos consensuados entre Estados Partes, aunque en su esencia y en su contexto de acción los cambios climáticos ignoren la soberanía y las fronteras políticas entre Estados Partes.

Lo cierto es que el equilibrio climático constituye un continuum ecológico que se extiende tanto en los espacios sometidos a soberanía territorial como más allá de ellos (RUIZ, 1999), y además, los impactos de este problema ambiental son y deben ser entendidos a largo plazo y se padecen realmente a nivel subnacional y local (BODANSKY, 1999). Y en este sentido la dualidad global-local del cambio climático inculca un sentido de la responsabilidad para afrontar este fenómeno en todos los niveles de la organización social (LITFIN, 2000).

\footnotetext{
${ }^{2}$ El Acuerdo está disponible en: http://unfccc.int/files/essential_background/convention/application/pdf/spanish_paris_agreement.pdf. Acceso en abr. 2018.
} 
En la literatura actual, los nuevos modelos de gobernanza ambiental son percibidos como ejemplos de deliberación y cooperación (VAN ZEIJL-ROZEMA et al., 2008; BODANSKY et al., 2017). Estos modos de gobernanza reclaman ser funcionales y manejar aspectos complejos, intersectoriales, multiescala y de largo alcance relacionados directamente con la problemática ambiental (JORDAN, 2008). Autores describen cómo la incertidumbre y el riesgo requieren de la participación activa de una gran variedad de actores, así como de la diversidad de acciones entre las distintas esferas del gobierno, la sociedad civil y el mercado (MEADOWCROFT, 2007). Otros, como Nölke y Graz (2007), garantizan la legitimidad y la calidad democráticas de estos nuevos modelos en diversos campos de la política ambiental global.

Según el Programa de las Naciones Unidas para el Medio Ambiente - PNUMA ${ }^{3}$

La gobernanza ambiental es clave para alcanzar el desarrollo sostenible, a nivel nacional, regional y global. Por ello, los procesos de toma de decisiones y el trabajo de las instituciones deben seguir métodos informados, coherentes, unificados e integrales $\mathrm{y}$, al mismo tiempo, deben apoyarse en marcos normativos adecuados que faciliten estos procesos.

La respuesta internacional motivada por el régimen jurídico sigue insuficiente, aunque más organizada con el Acuerdo de Paris. En realidad, la escasez de acciones prácticas para afrontar los problemas ambientales globales por parte de los Estados Partes dan legitimidad a la aparición de nuevas formas de autoridad, aunque carentes de soberanía, elementos de autonomía y control (BULKELEY, 2010).

En realidad, no se puede ignorar que se ha concedido a estas nuevas estructuras una legitimidad voluntaria por parte de la sociedad (DEDUERWAERDERE, 2005), gracias a la asunción de que, para afrontar de manera efectiva esos problemas, es necesaria una acción coordinada y de cooperación de los sistemas de gobierno en todos sus niveles (estatal, supraestatal, infra estatal, interestatal), siendo destacable la participación del nivel estatal, infra estatal (tanto regional como local) y de actores privados y no gubernamentales, cada uno de ellos jugando una variedad de papeles (BULKELEY, 2005).

En otras palabras

\footnotetext{
${ }^{3}$ De acuerdo con el subprograma, ONU Ambiente: disponible en: http://www.pnuma.org/gobernanza/.Acceso en apr. 2018.
} 
como los problemas ambientales atraviesan espacialmente las fronteras (afectando a múltiples jurisdicciones) y temporalmente el espacio (generando riesgos para las generaciones presentes y futuras), necesitan de cooperación entre las naciones y los grupos de stakeholders en una forma de gobernanza ambiental global (REED Y BRUYNEEL, 2010, p. 650).

El concepto de gobernanza ambiental global es sobretodo interesante no como un nuevo avatar de los ideales ilustrados del desarrollo sostenible mediante el derecho o la instauración de un gobierno mundial, sino como parte de la problemática de un sistema internacional dual que mantiene una divergencia entre su componente político y sus mecanismos de gestión de las problemáticas. Es decir, en el análisis de las consecuencias de esta dualidad y de los esfuerzos para superarla o adaptarse a ella.

O sea, a través de la gobernanza ambiental global se han creado de forma complementaria distintas manifestaciones de responsabilidad y niveles de acciones de enfrentamiento y de adaptación frente a los problemas ambientales. Como consecuencia de ello, y en eso resulta una acción de habilidad política y creatividad, el avance de los regímenes jurídicos se ha sustentado y generado resultados en actividades de desarrollo en los niveles infra estatal y transnacional y por actores que aún no son formalmente partes en el sistema legal internacional.

\subsection{Paradiplomacia ambiental}

Como aseverado, durante la primera década del siglo XXI, las actividades internacionales medioambientales de los gobiernos subnacionales han suscitado más y más el interés de representantes políticos y académicos, suponiendo uno de los temas de creciente investigación de la nueva gobernanza medioambiental global. Es que la necesidad de acciones prácticas para afrontar los problemas medioambientales globales, ha hecho posible y dado legitimidad a la progresiva aparición de nuevas formas de autoridad (REI y FARIAS, 2015).

Una de las facetas más dinámicas y comprometidas de esta nueva forma de gobernanza ambiental global son las acciones de los gobiernos subnacionales para afrontar los cambios climáticos y sus reflejos. Asociadas originariamente a una mayor participación de los gobiernos subnacionales en los problemas internacionales económicos, con la globalización como paradigma (DUCHACEK, 1984; DUCHACEK, 1990; MICHELMANN y SOLDATOS, 1990; KEATING, 1999; LECOURS, 2002; HOCKING, 2004; KEATING, 2005; MILANI у RIBEIRO, 2011; BODANSKY et al., 2017), el concepto de paradiplomacia comenzó también a usarse para expresar el creciente interés y la participación directa de estos actores en las 
agendas ambientales globales (HOCKING, 1996; BUENO DA SILVA, 2010; EATMON, 2009; BARBER, 2017).

En este trabajo, se utiliza el concepto de paradiplomacia ambiental en la inclusión de los gobiernos subnacionales en la dinámica del derecho ambiental internacional, que abraza la participación de otros niveles de gobierno y de actores en la búsqueda de soluciones para los complexos problemas de su agenda. Es decir, reconoce las iniciativas jurídicas y políticas internacionales y transnacionales establecidas en un gobierno subnacional para combatir los problemas ambientales globales. Tales iniciativas incluyen la firma de acuerdos y alianzas con regiones de países extranjeros, la participación en conferencias y eventos internacionales, así como la participación de estas entidades en las redes internacionales y transnacionales de los gobiernos subnacionales (REI y GRANZIERA, 2014).

En la literatura especializada, se identifican distintas claves de este movimiento más allá de las fronteras nacionales estatales. En un análisis de una serie de iniciativas locales y regionales en los Estados Unidos para afrontar los cambios climáticos, Engels y Orbach (2008) identificaron una correlación directa entre estas acciones y los deseos electorales o apoyo político de la población. De acuerdo con Bernstein et al. (2010), el estado de las negociaciones para hacer avanzar el régimen internacional de lucha contra el calentamiento global antes del Acuerdo de Paris aun estaba marcado por la resistencia de Estados Partes para asumir mayores y nuevos compromisos, lo cual parecía disminuir su legitimidad como interlocutores adecuados para la solución de este problema ambiental y reforzaba la oportunidad y el papel de otras autoridades y centros de toma de decisión, particularmente a aquellos de nivel subnacional y local.

Concretamente, como visto en el ítem 1.1, el Acuerdo de Paris al reconocer la importancia de esos nuevos actores internacionales en el proceso, en los esfuerzos y en las medidas destinadas a reducir las emisiones y/o a aumentar la resiliencia y disminuir la vulnerabilidad a los efectos adversos del cambio climático, igualmente refuerza la oportunidad y el papel que pueden desempeñar.

Además, la mayoría de los gobiernos subnacionales tienen competencias legislativas y administrativas sobre fuentes importantes de emisiones de gases de efecto invernadero. Por consiguiente, estos gobiernos son los encargados de definir políticas públicas destinadas -o al menos que tengan en consideración-, a la mitigación de los cambios climáticos (COLIER, 1997; NRG4SD, 2012).

O sea, al hablar de paradiplomacia ambiental se hace referencia a las condiciones necesarias para iniciar un proceso de vinculación internacional en una agenda donde la mayoría 
de esos gobiernos subnacionales que tienen competencias legislativas y administrativas sobre las fuentes más importantes de emisión de GEI quieren actuar (REI et al, 2012).

Es cierto que las iniciativas de los gobiernos subnacionales para afrontar los cambios climáticos globales han expandido el alcance de los resultados de la gobernanza ambiental (RABE, 2004, 1007; ROSENZWEIG et al. 2010; HOORNWEG et al. 2011). Okereke et al. (2009) afirman que, en algunos casos, estas actividades se suman a los esfuerzos nacionales e internacionales para afrontar el problema, ayudando a los Estados a cumplir sus compromisos internacionales. En otros casos, a pesar de la inercia de los gobiernos nacionales, las acciones subnacionales tienen como resultado reducciones efectivas de gases de efecto invernadero y acaban ejerciendo cierta influencia, directa o indirecta, en las negociaciones internacionales sobre los cambios climáticos, presionando a los Estados Partes para avanzar en sus compromisos y esfuerzos respecto de los problemas a afrontar.

Y naturalmente que los citados impactos de las iniciativas subnacionales en la gobernanza global ambiental acaban alcanzando mayor empuje cuando los actores subnacionales actúan de manera organizada en cooperaciones horizontales y redes solidarias (BULKELEY y BETSILL, 2003; BULKELEY, 2010; SETZER, 2013). A pesar de que las redes son inicialmente creadas como plataformas para el intercambio de información, técnicas, prácticas y experiencias en medidas adoptadas para afrontar los cambios climáticos, en la práctica, no se puede negar que estas redes transnacionales acaban jugando un papel político singular, sobre todo cuando actúan de forma coordinada en la esfera de la negociación internacional. Este es el caso de la Red de Gobiernos Regionales por el Desarrollo Sostenible (nrg4SD).

\section{La red de gobiernos regionales por el desarrollo sostenible - Nrg4SD}

Nrg4SD es una coalición internacional que reúne a nivel mundial a gobiernos subnacionales y asociaciones regionales de gobiernos subnacionales. La red promueve el entendimiento, la colaboración y las asociaciones en materia de desarrollo sostenible, y persigue un mayor reconocimiento internacional de la importancia de las contribuciones de los gobiernos subnacionales (únicamente regionales) al desarrollo sostenible (REI y FARIAS, 2015).

Nrg4SD fue creada por ciertos gobiernos regionales participantes en la Cumbre Mundial sobre Desarrollo Sostenible de Johannesburgo (2002), en una Conferencia paralela. De esta Conferencia paralela resultó la Declaración de Gauteng, firmada por 23 gobiernos 
subnacionales, en la que de un lado se ponía de manifiesto la importancia de los gobiernos subnacionales en asuntos de desarrollo sostenible así como de su cooperación entre sí; y de otro lado, se acordaba el deseo de crear una red de gobiernos subnacionales a nivel mundial para el desarrollo sostenible (DECLARACIÓN DE GAUTENG, 2002). A partir de la Conferencia de San Sebastián de 2003 se inicia la personalización jurídica de la red, que se registra legalmente en 2004 como una "Asociación Internacional sin ánimo de lucro", bajo la ley belga.

En la actualidad, la red cuenta con más de 50 miembros de derecho, de casi 30 países y de 4 continentes y 7 asociaciones de regiones, además de observadores, representando en realidad la voz de más de 1000 gobiernos regionales a nivel mundial, ya que Nrg4SD es miembro del Foro Global de Asociaciones de Regiones (FOGAR) y, por mandato de representación, su portavoz para los temas de desarrollo sostenible.

Para coordinar sus actividades, nrg4SD ha creado un Steering Committee (Grupo Promotor), que actúa como el órgano de gobierno de la red. El Steering Committee se reúne dos veces al año en sesiones ordinarias y tiene la función de convocar anualmente a la Asamblea General. El Steering Committee trata de garantizar un equilibrio geográfico en la red, alentando la condición de miembro entre regiones pertenecientes a países en desarrollo. Los miembros del Steering Committee se eligen por un periodo de tres años sin restricciones para la reelección; éstos eligen a su vez de entre sus miembros dos Presidentes (Co-Presidente Norte; CoPresidente Sur), cinco puntos focales continentales (Vice-Presidentes) y una Tesorería. Y para ayudarles en sus tareas y decisiones cuentan con un cuerpo de Consultores (Board of Advisors), que representan los dos hemisferios.

Al observar el listado de regiones miembro de nrg4SD, es inevitable admitir que las regiones europeas aun tienen un mayor peso respecto al resto de los miembros de la red (HAPPAERTS et al., 2010, 2011), y eso tiene su explicación en la existencia de un alto nivel de actividad regional en Europa (JONES y KEATING, 1996; PETSCHEN, 1993; PINRATIS, 1995; DE CASTRO RUANO, 1994; HOOGHE, 1996) la cual se debe principalmente a dos motivos: por un lado, Europa como comunidad de culturas (EULATE et al., 2003; MARTIN y NOGUERAS, 1996; MORENO, 1993) comparte unas raíces históricas, culturales y jurídicas que favorecen la cooperación y compatibilidad de sus regiones; por otro lado, la Unión Europea (UE), como organización supranacional de integración europea, ha creado amplias oportunidades para que las regiones ejerzan influencia de forma independiente de sus Estados (KEATING, 2005).

Merece destaque la aportación cuantitativa que las Comunidades Autónomas Españolas - CCAA realizan a nrg4SD con su compromiso y trabajo, pero cabe destacar además 
su contribución cualitativa a la red, la cual ha permitido el estrechamiento de las relaciones con las regiones de Latino América y Caribe -con quienes comparten unas importantes raíces lingüísticas y culturales- fruto del cual se han desarrollado destacables colaboraciones. Hoy en día, las regiones de Latino América y Caribe y las CCAA representan un eje propio de actividades en el régimen multilateral de nrg4SD, con vigor y liderazgo.

Al objeto de fortalecer sus acciones de defensa de los esfuerzos de los gobiernos regionales subnacionales contra el calentamiento global, nrg4SD ha sido acreditada oficialmente ante la UNFCCC como observador social. Además, nrg4SD cuenta con un Grupo de Trabajo permanente respecto a las negociaciones internacionales sobre cambio climático y ha lanzado recientemente un Grupo de Trabajo Técnico para la financiación de la acción climática a nivel subnacional.

Todo esto ha permitido a nrg4SD trabajar directamente con el Secretariado de la Convención y con algunas Partes de la misma, así como representar directamente en las negociaciones internacionales a aquellos gobiernos subnacionales que son miembro de la red. En estas negociaciones, nrg4SD (i) defiende de forma constante un mayor reconocimiento de la crucial aportación de los gobiernos subnacionales a la acción sobre el cambio climático, (ii) trabaja con el Secretariado y los grupos de trabajo de la UNFCCC en temas técnicos y (iii) aporta de forma regular a los debates la presencia de las delegaciones subnacionales, así como sus iniciativas (NRG4SD, 2012).

Con objeto de influir en el proceso de negociación sobre cambio climático, la red ha venido trabajando de forma institucional con otras redes de gobiernos subnacionales, como The Climate Group (TCG), los Gobiernos Locales para la Sostenibilidad (ICLEI) y las Ciudades y Gobiernos Locales Unidos (UCLG). Esta colaboración entre redes de gobiernos subnacionales supone un esfuerzo estratégico para la creciente concienciación ciudadana en una acción cotidiana respecto al cambio climático. Además representa un contexto inédito entre los gobiernos subnacionales para contribuir a adaptar la gobernanza internacional del cambio climático a los tiempos modernos (REI et al, 2013).

Cabe aún destacar la serie de eventos paralelos organizados por la nrg4SD en las últimas cuatro COPs, en Lima, en Paris, Marraquech y Bonn, donde se ha dado seguimiento a una dinámica general de trabajo y actividades concretas entre sus miembros para desarrollar mensajes comunes y documentos estratégicos de apoyo dirigidos al proceso internacional, concretamente al proyecto de la Iniciativa Regions Adapt.

Sin embargo, nrg4SD es consciente de que el reto humano, económico y medioambiental que supone el cambio climático no acaba sino de comenzar. Por ello, la red 
sigue reclamando por mejores estructuras de gobernanza capaces de dar cabida a las acciones de los gobiernos subnacionales y dispuestas a evolucionar hacia una aproximación multidimensional y complementaria en la lucha contra el calentamiento global.

\subsection{Iniciativa Regions Adapt - una alianza subnacional para la adaptación al cambio climático}

Aunque se interrumpieran de inmediato las emisiones antropogénicas de gases de efecto invernadero, la humanidad seguiría durante siglos siendo víctima del cambio climático y sus efectos. El cambio climático genera nuevos riesgos y amplifica los ya existentes para los sistemas naturales y humanos, riesgos asociados a una gran variedad de impactos ya observables. Tal y como reconoce el Grupo Intergubernamental de Expertos en Cambio Climático (IPCC), estos riesgos se distribuyen de forma desigual entre los territorios y, casi siempre, afectan en mayor medida a las personas y comunidades desfavorecidas, más vulnerables (NRG4SD, 2015). Y a la hora de gestionar y reducir los riesgos del cambio climático, proponiendo al mismo tiempo alternativas resilientes para un desarrollo sostenible, la adaptación y la mitigación son estrategias cruciales, complementarias y desafiadoras.

Los gobiernos regionales desempeñan un papel fundamental y estratégico a la hora de mejorar la coordinación y la cooperación entre los diferentes niveles gubernamentales, para fomentar la coherencia de las políticas y asegurar que las acciones de adaptación produzcan resultados concretos con el apoyo de la comunidad participante. En este sentido, la escala subnacional resulta especialmente importante para una respuesta de adaptación contundente.

Sin embargo, el apoyo y la cooperación internacional para actuar a escala regional en pro de la adaptación siguen siendo vías poco exploradas. Si bien muchos gobiernos regionales de nrg4SD han desarrollado ya estrategias de adaptación a largo plazo y soluciones innovadoras para incrementar la resiliencia, todavía existen una serie de limitaciones y retos que frenan su capacidad para responder de manera eficaz.

Esto incluye naturalmente la falta de recursos económicos y humanos, la no siempre fácil integración y coordinación entre los diferentes niveles de gobierno, así como insuficientes prácticas en materia de gestión, investigación y herramientas para monitorizar la eficacia de la adaptación y, lo que es más importante, la ausencia de planificación de la adaptación a medio y largo plazo (NRG4SD, 2015).

En este escenario, y reconociendo que las responsabilidades legales y las capacidades técnicas y económicas varían considerablemente en cada jurisdicción, miembros de nrg4SD 
toman la iniciativa de participar de Regions Adapt y se comprometen a unir esfuerzos para mejorar la eficacia de los gobiernos regionales en la adaptación al cambio climático.

En tanto que proyecto de cooperación internacional, la iniciativa Regions Adapt tiene por objeto facilitar y apoyar la colaboración entre gobiernos regionales y otros socios internacionales relevantes, llevando a cabo esfuerzos conjuntos basados en los principios de la solidaridad.

Con esta aspiración, los miembros participantes se comprometen a:

1. Adoptar un enfoque estratégico a la adaptación y priorizar las acciones de adaptación mediante, por ejemplo, la aprobación o revisión de un plan o una estrategia regional de adaptación al cambio climático, en los dos años siguientes a sumarse a la iniciativa.

2. Implementar acciones concretas para la adaptación en, al menos, uno de los temas prioritarios identificados. Esto podría incluir: recursos hídricos y su gestión; resiliencia y reducción de riesgo de desastres; agricultura y zootecnia; bosques, áreas protegidas y biodiversidad, infraestructuras (incluidos los sectores del transporte y la energía) y planificación territorial; efectos y oportunidades en el ámbito económico; y adaptación e impacto social.

3. Dar a conocer los datos sobre el progreso de las acciones de adaptación anualmente a través del Pacto de Estados y Regiones (NRG4SD, 2015).

Actualmente, como indican Rei y Pinho (2017) participan de la iniciativa las siguientes regiones: Australian Capital Territory (Australia), Azuay (Ecuador), País Vasco (España), British Columbia (Canada), California (USA), Cataluña (Espanha), Ceará (Brasil), Fatick (Senegal), Goiás (Brasil), Gossas (Senegal), Jalisco (Mexico), KwaZulu-Natal (South Africa), Lombardía (Italia), Paraná (Brazil), Prince Edward Island (Canada), Québec (Canada), Rio de Janeiro (Brasil), Rio Grande do Sul (Brasil), Saint Louis (Senegal), São Paulo (Brasil), South Australia (Australia), Sud-Comoé (Costa del Marfil), Tocantins (Brasil), Tombouctou (Mali), Vermont (Canada), Wales (Reino Unido) y Western Province (Sri Lanka), listado que confirma la importante y robusta participación de estados brasileños.

\section{Conclusiones}

Se puede afirmar que la clave para comprender la globalización se basa en una gobernanza correcta y moderna, y el enorme reto del cambio climático debe entenderse en términos de oportunidades y realidades. Es en esta lectura positiva de los retos del siglo XXI donde se encuentra la base para crear un liderazgo en la acción climática que esté guiado por la ambición y el realismo. 
Como los Estados Partes son cada vez más conscientes de la complejidad de los problemas ambientales, puede afirmarse que crece una aceptación internacional de que las relaciones ambientales a nivel internacional son relaciones multilaterales y multiniveles, y no más relaciones regionales o bilaterales entre apenas esos Estados Partes.

En otras palabras, las actividades paradiplomáticas ambientales pueden ser explicadas y legitimadas a través de una teorización de los vínculos verticales y horizontales que participan en la gestión de los problemas ambientales globales. En efecto, ha sido posible crear un escenario cada vez más participativo, que se alimenta en un movimiento legal innovador que aporta la base para un trabajo normativo que debe ser actualizado y revisto de forma permanente.

Esta aceptación internacional ha abierto progresivamente la forma de participación del público - particulares, sociedades científicas, academias, Organizaciones No GubernamentalesONG, pueblos indígenas y aborígenes, asociaciones de gobiernos regionales etc. - y hará posible que se continúe con el desarrollo de una conciencia de los problemas comunes relacionados con el Derecho Internacional, con la diplomacia, hasta que se logre un nuevo pacto de legitimidad global, a la luz de un nuevo orden internacional, que realmente reconozca las nuevas y complejas realidades, guiados incluso por la Agenda 2030, donde los gobiernos subnacionales tienen un nuevo papel, ya que sus contribuciones y liderazgo son esenciales como ayuda para lograr los objetivos últimos del desarrollo sostenible, papel perfectamente reconocido por el Derecho Ambiental Internacional.

$\mathrm{Y}$ en esta experiencia paradiplomática, reconocer que la cooperación y el entendimiento entre Redes, lideradas por nrg4SD, lejos de crear competitividades, ha funcionado como un ejemplo de unión de fuerzas y apoyo mutuo para reclamar en los foros internacionales, en particular del sistema de Naciones Unidas, la importancia del papel de los gobiernos subnacionales en la gestión de los asuntos multilaterales de desarrollo sostenible y de pragmatismo en la identificación de oportunidades de cooperación entre las regiones del mundo, como sugiere na iniciativa Regions Adapt.

\section{Referencias}

BARBER, B.. Cool Cities, Urban Sovereignty and the fix for Global Warming. New Haven and London: Yale University Press, 2017. 
BODANSKY, D.. The legitimacy of international governance: a coming challenge for international environmental law?. The American Journal of International Law - vol.93, n.3, 1999, p.596-624.

BODANSKY, D.; BRUNNEE, J.; HEY, E.. The Oxford handbook of international environmental law. Oxford: Oxford University Press, 2008.

BODANSKY, D.; BRUNNEE, J.; RAJAMANI, L.. International Climate Change Law. Oxford: Oxford University Press, 2017.

BUENO DA SILVA DA SILVA, E.. Contemporary paradiplomacy: trajectories and trends of international actions by state governments of Brazil and the US. Doctorate thesis submitted to the International Relations Doctorate Program of the International Relations Institute of the University of Brasília (IREL/UnB) for obtaining a doctor degree in international relations, 2010 .

BULKELEY, H.. Reconfiguring environmental governance: towards a politics of scales and networks. Political Geography, n. 24, 2005, p.875-902.

BULKELEY, H.. Cities and the Governing of Climate Change. Annual Review of Environment and Resources, 35(1), 2010, p. 229-253.

BULKELEY, H., \& BETSILL, M.. Cities and Climate Change: urban sustainability and global environmental governance. Oxon: Routledge, 2003.

DE CASTRO RUANO, J.L.. La emergente participación política de las regiones en el proceso de construcción europea. Vitoria: Instituto Vasco de Administración Pública, 1994.

DEDUERWAERDERE, T.. The contribution of network governance to sustainable development. Belgium: Université Catholique de Louvain Fonds National de la Recherche Scientifique, 2005.

DUCHACEK, I.D.. The international dimensions of subnational self-government. Publius, 14(4), 1984, p. 5-31. 
DUCHACEK, I. D.. Perforated Sovereignties: Towards a Typology of New Actors in International Relations. In H. J. Michelmann \& P. Soldatos (Eds.), Federalism and International Relations: The Role of Subnational Units. Oxford: Clarendon Press, 1990.

EATMON, T.D.. Paradiplomacy and Climate Change: American States as Actors in Global Climate Governance. Journal of Natural Resources Policy Research. 1(2), 2009, p. 153-165.

ENGELS, K.H., ORBACH, B.Y.. Micro-motives and state and local climate change initiatives. Harvard Law and Policy Review, vol.2, 2008, p. 119-137.

HAPPAERTS, S., VAN DEN BRANDE, K., BRUYNINCKX, H.. Governance for Sustainable Development at the Inter-subnational Level: The Case of the Network of Regional Governments for Sustainable Development (nrg4SD). Regional \& Federal Studies 20(1), 2010, p. 127-149.

HAPPAERTS, S., VAN DEN BRANDE, K., BRUYNINCKX, H.. Multi-level interactions in a sustainable development context: different routes for Flanders to decision-making in the UN commission on sustainable development. Environmental Policy and Governance 21(1), 2011, p. $70-82$.

HOCKING, B.. The woods and the trees: Catalytic diplomacy and Canada's trials as a 'forestry superpower'. Environmental Politics 5(3), 1996, p. 448-475.

HOCKING, B.. Regionalismo: uma perspectiva das relações internacionais. In VIGEVANI, T., WANDERLEY, L.E., BARRETO, M.I., MARIANO, M.P (org.). A dimensão subnacional e as relações internacionais. São Paulo: EDUC; Fundação Editora da UNESP, 2004.

HOOGHE L.. Cohesión Policy and European Integration, Oxford: Claredon, 1996.

JONES B., KEATING M.. The European Union and the Regions, Oxford: Clarendon, 1996.

JORDAN, ANDREW 2008. The Governance of Sustainable Development: Talking Stock and Looking Forward., Environment and Planning, núm. 26, 2008, p. 17-33. 
KEATING, M.. Regions and international affairs: motives, opportunities and strategies. In ALDECOA, F. KEATING, M. Paradiplomacy in action: the foreign relations of subnational governments. London: Frank Cass Publishers, 2005.

LECOURS, A.. Paradiplomacy: reflections on the foreign policy and international relations of regions. International Negotiation, 7, 2002, p. 91-114.

LITFIN, K.T.. Environment, Wealth and Authority: global climate change and emerging modes of legitimation. International Studies Review, vol.2, n. 2, 2000, p.119-148.

MATEO, R.M.. Tratado de derecho ambiental. Vol II. Madrid: Trivium, 1992.

MEADOWCROFT, JAMES. Who is in Charge Here? Governance for Sustainable Development in a Complex World. Journal of Environmental Policy and Planning, vol. 9, núm. 3-4, 2008, pp. 299-314.

MICHELMANN, H.J., SOLDATOS, P. (Eds). Federalism and International Relations: The Role of Subnational Units. Oxford: Oxford University Press, 1990.

MILANI, C.R.S., RIBEIRO, M.C.M.. International relations and the paradiplomacy of Brazilian cities: crafting the concept of local international management. Brazilian Administration Review, vol.8, n.1. 2001.

NÖLKE, ANDREAS. GRAZ, JEAN-CHISTOPHE. Limits of the Legitimacy of Transnational Private Governance, ponencia presentada en el seminario Pathways to Legitimacy. The Future of Regional and Global Governance, Universidad de Warwick, 17-19 de septiembre, 2007.

NRG4SD. Network of Regional Governments for Sustainable Development. Available at http://www.nrg4sd.org/. Acceso en abril de 2018.

NRG4SD. Regions Adapt 2016 Report: An assessment of risks and actions. Disponible en: http://www.nrg4sd.org/wp-content/uploads/2017/01/RA2016REPORT_FINAL-1.pdf. Acceso en abril de 2018. 
OKEREKE, C. BULKELEY, H. SCHROEDER, H.. Conceptualizing climate governance beyond the international regime. Global Environmental Politics, vol.9, n.1, 2009, p.58-68.

PETSCHEN S.. La Europa de las Regiones, Barcelona: Generalitat de Catalunya, 1993

RABE, B. G.. Statehouse \& Greenhouse: The Emerging Politics of American Climate Change Policy. Washington, DC: Brookings Institution Press, 2004.

REED E BRUYNEEL, M.G., BRUYNEEL, S.. Rescaling environmental governance, rethinking the state: a three-dimensional review. Progress in Human Geography, vol. 34, n.5, 2010, p. 646-653.

REI, F.C.F., CUNHA, K.B., SETZER, J. La Paradiplocia Ambiental en la Nueva Governanza Internacional. Revista TIP n.2. Buenos Aires, 2012, p. 50-63.

REI, F.; CUNHA, K.; VERA, N.. La paradiplomacia medioambiental global y el papel de las comunidades autónomas españolas. Revista Foro Internacional, v. LIII_2, n. 212, 2013, p. $337-362$

REI, F.; GRANZIERA, M. L. M.. Direito Ambiental Internacional: Novos olhares para a ciência do direito. São Paulo: Atlas, 2014

REI, F; FARIAS, V. C.. Paradiplomacia Ambiental: La Cooperación Descentralizada Hispano-Brasileña. Conpedi Law Review; v. 1, n. 16 , 2015, p. 115-135

REI, F; PINHO, M.M.L.. Paris Agreement and the Regions Adapt Initiave: The Role of Transnational Action in the Adoption and Implementation of Climate Policies. International Journal of Science, Technology and Society; 5(4), 2017, p. 91-96

ROSENZWEIG, C., SOLECKI, W., HAMMER, S. A., MEHROTRA, S.. Cities lead the way in climate-change actio. Nature 467, 2010, p. 909-911.

RUIZ, J.J.. Derecho Internacional del medio ambiente. Madrid: McGraw-Hill, 1999. 
SETZER, J.. Governança multinível das mudanças climáticas: políticas subnacionais e ações transnacionais em São Paulo. In REI, F.C.F. (Org.). Direito e desenvolvimento: uma abordagem sustentável. São Paulo: EdRT, 2013.

VAN ZEIJL-ROZEMA, ANNEMARIE, RON CÖVERS, RENÉ, KEMP, PIM MARTENS.

Governance for Sustainable Development: a Framework, Sustainable Development, núm. 16, 2008, p. 410-421. 


\title{
QUESTÕES SOBRE A EFICÁCIA DO DIREITO INTERNACIONAL NO DESENVOLVIMENTO ECONÔMICO BRASILEIRO: 2004-2014
}

\author{
Carlos Leonardo Loureiro Cardoso
}

Universidade Veiga de Almeida - RJ

\begin{abstract}
Resumo
O presente trabalho visa a expor e a analisar o resultado do desenvolvimento econômico no Brasil durante os anos de 2004 a 2014, perante a comunidade internacional, especialmente a ONU, à luz do Direito Internacional Público (DIP), a fim de perceber a necessidade de manutenção do status do país como potência na América Latina. Com base na Constituição Federal de 1988, considera-se no presente artigo a preocupação do legislador brasileiro em defender a posição do país no cenário internacional, por meio da soberania, e a inter-relação com as disciplinas de Direito Constitucional e DIP.
\end{abstract}

Palavras-chave: Direito Internacional Público, desenvolvimento econômico, Constituição da República Federativa do Brasil de 1988, Organização das Nações Unidas.

\begin{abstract}
Resumen/Résumé
El presente artículo analiza el resultado del desarrollo económico en Brasil entre 2004 e 2014, ante la comunidad internacional, especialmente la ONU, a la luz del Derecho Internacional Público, además de proponer la comprensión de la necesidad de mantener el status del país como potencia en América Latina. Con base en la Constitución Federativa del Brasil de 1988, se considera en el presente artículo la preocupación del legislador brasileño en defender la posición del país en el escenario internacional, por medio de la soberanía y de la interrelación con las disciplinas de Derecho Constitucional.
\end{abstract}

Keywords/Palabras-claves/Mots-clés: Derecho internacional público, política exterior brasileña, desarrollo económico, Constitución Federativa del Brasil, Naciones Unidas. 


\section{Introdução}

O presente trabalho tem o objetivo específico de analisar o compromisso brasileiro com o desenvolvimento econômico perante a ONU, à luz do Direito Internacional Público (DIP), no período de 2004 (segundo ano de governo de Luis Inácio Lula da Silva) a 2014 (último ano do primeiro governo de Dilma Rousseff). Sendo assim, este artigo tem o objetivo geral de analisar a perspectiva brasileira perante a sociedade internacional contemporânea à luz do DIP, no que concerne à manutenção do status do País como potência na América Latina.

Para isso, foi necessário buscar as fontes deste trabalho em obras referentes ao DIP e ao Direito Constitucional, além de analisar, pelo método qualitativo, pesquisas direcionadas às transformações no panorama econômico mundial já no recente ano de 2014, por exemplo. Inicialmente - antes mesmo de iniciar a revisão de literatura - a pesquisa fora baseada no artigo $4^{\text {o }}$ da Constituição da República Federativa do Brasil de 1988, para compreensão da ideia do legislador em defender a posição do País no cenário internacional ${ }^{1}$.

A importância do trabalho no meio acadêmico justifica-se pelo levantamento da hipótese de que os padrões estabelecidos pelas Metas de Desenvolvimento do Milênio da ONU, entre outros deveres acordados perante outros países no decorrer do período em análise, apesar de terem sido positivos para o Brasil de um modo geral, ainda estão longe de serem conquistados em sua integralidade. As Metas foram estabelecidas em setembro de 2000, em Nova Iorque, por meio da Declaração do Milênio, com o compromisso - por parte dos 191 países participantes - de combater a pobreza extrema, bem como outros problemas graves na sociedade (PNUD, 2018).

No âmbito do desenvolvimento econômico, vale lembrar que o ECOSOC, Conselho Econômico e Social das Nações Unidas, é destinado aos estudos de organização e integração econômica, da independência dos povos, além de outros assuntos como, por exemplo, o direito da mulher e o direito trabalhista internacional. As Metas do Desenvolvimento do Milênio fizeram do Conselho um importante fator de coordenação de funcionamento do sistema das Nações Unidas. Dentre as comissões do Conselho podemos destacar a UNESCO e a própria

\footnotetext{
${ }^{1}$ Vale destacar a seguinte redação do art. $4^{\circ}$ da Constituição Federal de 1988: “A República Federativa do Brasil rege-se nas suas relações internacionais pelos seguintes princípios: I - independência nacional; II - prevalência dos direitos humanos; III - autodeterminação dos povos; IV - não-intervenção; V - igualdade entre os Estados; VI - defesa da paz; VII - solução pacífica dos conflitos; VIII - repúdio ao terrorismo e ao racismo; IX - cooperação entre os povos para o progresso da humanidade; X - concessão de asilo político. Parágrafo único. A República Federativa do Brasil buscará a integração econômica, política, social e cultural dos povos da América Latina, visando à formação de uma comunidade latino-americana de nações".
} 
OIT (ECOSOC, 2018).

Tendo em vista a perspectiva da posição do Brasil no âmbito internacional no período delimitado para este trabalho, Maria Regina Soares de Lima e Monica Hirst explicam que

(...) apesar de muitos comentadores terem enfatizado o alto grau de estabilidade da política externa brasileira ao longo dos anos, não há dúvida de que, desde a inauguração do governo Lula em janeiro 2003, a mudança tem predominado sobre a continuidade. A inclusão da agenda social como tópico importante da política externa foi uma das primeiras e maiores inovações (LIMA; HIRST, 2009, p.44).

As autoras seguem afirmando que

O Brasil também veio a conceder ênfase muito maior à necessidade de revisão conceitual e reforma prática de grandes instituições internacionais, especialmente a ONU, e tem expressado particular preocupação com a distribuição desigual de poder e riqueza no interior de tais instituições e as distorções que a ordem vigente impõe (2009, p.44).

A continuidade a qual elas se referem diz respeito à política externa (e também econômica) de Fernando Henrique Cardoso (1995-2003). Nessa linha de pensamento, o Direito Internacional, que é, em sua totalidade, os Tratados (ou Convenções Internacionais) encoraja, de fato, o Brasil a cumprir o estabelecido e a respeitar as obrigações. Num primeiro parâmetro, que será concretizado na segunda parte do artigo, haverá a análise dos padrões ajustados pelo País para o desenvolvimento econômico, e também de alguns acordos garantidos pelo Brasil.

$\mathrm{Na}$ terceira parte, há uma reflexão sobre a eficácia do Direito Internacional nas Relações Internacionais do Brasil no período de 2004 a 2014, com a devida explicação teórica de Direito Internacional. A base teórica foi buscada em Francisco Rezek (1998) e Celso D. de Albuquerque Mello (1990). Na quarta parte será identificada brevemente a relação existente entre Direito Internacional e Política Internacional, numa perspectiva brasileira e no período delimitado.

Por fim, a conclusão visa à reflexão do que foi analisado nos três capítulos e também tem a intenção de ressaltar a importância de o Brasil participar de tratados Internacionais em prol do desenvolvimento econômico interno. 


\section{Uma breve análise dos padrões ajustados pelo País para o desenvolvimento econômico - tratados e acordos aceitos ou garantidos pelo Brasil}

A política econômica do Brasil no panorama internacional, a partir de 2004, ano pertencente ao primeiro governo de Luis Inácio Lula da Silva, ganhou notoriedade pelo fortalecimento do MERCOSUL, ressaltando o papel do País como potência regional dominante, dentro da América Latina, bem como pela sua maior participação no cenário internacional perante outras potências regionais, como África do Sul, Índia e Rússia.

O presente trabalho não pretende discutir, analisar ou entrar no mérito da posição econômica dos governos de 2004 a 2014, mas tão somente focar no Direito Internacional e nas posições as quais os governos adotaram perante outros países, no que se refere ao desenvolvimento econômico brasileiro.

O Brasil pretendeu, segundo Amaury de Souza, defender uma ordem internacional multipolar, transformar o país num ator global, esforçar-se para democratizar processos de decisão das estruturas internacionais, especialmente o Conselho de Segurança da Organização das Nações Unidas (SOUZA, 2009, p.141).

Nesse sentido, o Brasil tentou, por um lado, juntamente com países emergentes, destacar-se no desempenho de seu papel no jogo político mundial, embora a ONU, bem como as instituições financeiras internacionais, não lhes tenham possibilitado o inteiro alcance às posições de maior destaque e influência.

Por outro lado, a sociedade internacional, de uma maneira mais abrangente, tem efetivo impacto no processo de decisão em escala global, perante a realidade do século XXI. Não há mais o panorama unipolar do mundo; existe, sim, o ponto de vista da multilateralidade ou, ainda, da multipolaridade, fazendo parte daí os países emergentes.

O governo Lula, cabe lembrar, esforçou-se por manter reforçada a atuação internacional do País - seguindo (mas não totalmente) os preceitos de seu antecessor, Fernando Henrique Cardoso, que garantiu a confiança dos Estados Unidos por meio da integração do Brasil no "Consenso de Washington”.

De uma maneira geral, o consenso induzia a retirada da antiga postura de um país de terceiro mundo ${ }^{2}$. Tal postura foi reforçada após 2003, a qual vinha sendo desenvolvida

\footnotetext{
${ }^{2}$ Paulo Nogueira Batista descreve breve e precisamente o Consenso: "Em novembro de 1989, reuniram-se na capital dos Estados Unidos funcionários do governo norte-americano e dos organismos financeiros internacionais ali sediados - FMI, Banco Mundial e BID - especializados em assuntos latino-americanos. O objetivo do encontro, convocado pelo Institute for International Economics, sob o título 'Latin American Adjustment: How Much Has
} 
desde a carta do Partido dos Trabalhadores (PT), após a vitória de Lula nas eleições: "Estimularemos a ideia de uma globalização solidária e humanista, na qual os povos dos países pobres possam reverter essa estrutura internacional injusta e excludente"3.

A partir de 2003, portanto, o Brasil teve diplomacia constante perante o G-20 e a OMC. O Comunicado Ministerial do Grupo dos 20, por ocasião da V Conferência Ministerial da Organização Mundial do Comércio, em Cancún, México, no dia 09 de setembro de 2003, assim esclarecia:

Subsídios à exportação devem ser eliminados. Razões de ordem econômica, política, técnica e ética contribuem para tornar sua continuidade uma aberração. Simultaneamente, regras mais estritas devem ser estabelecidas sobre créditos à exportação e ajuda alimentar. Estas formas de elisão de compromissos em subsídios à exportação não podem continuar a distorcer a competição entre exportadores (GARCIA, 2008, p.709).

O acordo segue ainda que "com relação a acesso a mercados, o G-20 propõe melhoras substanciais por meio de cortes tarifários mais profundos e da eliminação de salvaguarda especial para países desenvolvidos” (2008, p.709).

Desde então, até 2008, para que possa haver uma real compreensão da atuação diplomática do Brasil, o Brasil obteve mais oito documentos importantes para o desenvolvimento econômico: o Comunicado conjunto de imprensa do G-4 (Brasil, Índia, Japão e Alemanha) e a ONU (2004); a Comunidade Sul-Americana de Nações (2004); a I Cúpula América do Sul-Países Árabes (2005); a Nacionalização do Petróleo e do Gás na Bolívia (2006); a Cooperação sobre biocombustíveis com os EUA (2007); a Parceria estratégica Brasil-União Europeia (2007) e; o Tratado Constitutivo da UNASUL, em 2008 (GARCIA, 2008, p.10).

Até o ano de 2010, a Política Externa permaneceu baseada neste panorama, até a política delineada no governo Dilma Rousseff. A política desse novo governo foi confiada com base na continuidade do PT, embora a atuação internacional do País dali em diante tenha

\footnotetext{
Happened?', era proceder a uma avaliação das reformas econômicas empreendidas nos países da região. Para relatar a experiência de seus países também estiveram presentes diversos economistas latino-americanos. Às conclusões dessa reunião é que se daria, subsequentemente, a denominação informal de 'Consenso de Washington"'. In: BATISTA, Paulo Nogueira. O Consenso de Washington: a visão neoliberal dos problemas latino-americanos. $<\mathrm{http}: / / \mathrm{www}$.consultapopular.org.br/sites/default/files/consenso $\% 20 \mathrm{de} \% 20$ washington.pdf $>$. Acesso em: 30/04/2018.

${ }^{3}$ A carta foi extraída do portal Compromisso com a mudança - documentos históricos do PT. 2002. $<\mathrm{http} / / /$ www.pt.org.br/portalpt/images/stories/arquivos/compromissocomamudanca.pdf $>$. No último acesso, em 30/04/2018, esse link não estava mais disponível.
} 
tomado novos rumos. A crise econômica, a partir de 2011, fora, por meio de discursos oficiais perante a ONU, a pauta principal, assim como a Reforma do Conselho de Segurança da ONU.

Nesse período, o Brasil manteve a cooperação Sul-Sul, por meio do investimento na criação de instituições com o intuito de comprometer-se com parceiros do Sul - a UNASUL - União das Nações Sul-americanas (no continente americano). Vale ressaltar que o Brasil manteve-se no G-20, na OMC, levando em conta também os BRICS - termo cunhado por Jim O’Neil, em referência ao grupo formado por Brasil, Rússia, Índia, China e África do Sul - como grupo de países emergentes mais significativos depois da crise de 2008.

Os integrantes do grupo foram importantes atores em favor da recuperação econômica global. Instituições também existentes foram mobilizadas. Ainda foi convidada para o MERCOSUL, durante esse período, a Venezuela.

Um compromisso, em especial, fez parte da pauta internacional do Brasil desde o ano 2000: a Declaração do Milênio, definida em Nova Iorque e que "reflete as preocupações de 147 chefes de Estado e de Governo e de 191 países" ". A Declaração é considerada como um documento das Nações Unidas.

Dessa declaração surgiram as Metas de Desenvolvimento do Milênio, que teve o intuito de afirmar o compromisso e o acordo internacional dos Estados, nas áreas de desenvolvimento econômico, saúde e educação, por exemplo. Ao todo, foram oito objetivos traçados, com o desafio de serem cumpridos até o ano de $2015^{5}$.

No que diz respeito ao desenvolvimento econômico, o objetivo número 8 estabelece parcerias entre os países em prol desse desenvolvimento, fomentando atitudes como a redução da dívida externa de países pobres muito endividados, chamados de PPME.

Além disso, o acordo visava a melhorar as estratégias de comunicação da maioria das nações do sul do planeta e capacitar profissionais ao livre acesso ao mercado e à tecnologia. Dessa forma, abriam-se as portas da concorrência livre entre países considerados desenvolvidos, com empresas de grande porte e renome, e aqueles países que não eram considerados desenvolvidos.

No entanto, nos últimos anos, mais precisamente no primeiro mandato de Dilma Rousseff, a Política Externa diferenciou-se do governo anterior, o que acarretou num novo perfil, perante uma fraca capacidade de foros econômicos internacionais em resolver

\footnotetext{
${ }^{4}$ Disponível em: $<$ http://www.pnud.org.br/Docs/declaracao_do_milenio.pdf $>$. Acesso em 30/04/2018.

${ }^{5}$ Disponível em: <http://www.pnud.org.br/odm.aspx>. Acesso em 30/04/2018.
} 
problemas de conflitos de interesses estagnados há muito tempo, como a própria Rodada Doha da OMC, Organização Mundial do Comércio (VEIGA; RIOS, 2011).

É necessário lembrar que houve transformações no panorama econômico mundial que refletiram numa nova atitude política do Brasil perante os outros Estados. Desde então, a continuidade das Relações Internacionais do governo Lula tornou-se impraticável. Destaca no discurso de Dilma Rousseff que "O mundo se defronta com uma crise que é, ao mesmo tempo, econômica, de governança e de coordenação política.” (ROUSSEFF, 2014). A presidente àquela época segue no mesmo discurso, afirmando que "enfrentamos uma crise econômica que, se não debelada, pode se transformar em uma grave ruptura política e social. Uma ruptura sem precedentes, capaz de provocar sérios desequilíbrios na convivência entre as pessoas e as nações." (2014).

Apesar da ruptura com a Política Externa do governo anterior, um ponto positivo no governo de Dilma Rousseff foi a eleição do Brasil ao Conselho Econômico e Social das Nações Unidas (ECOSOC). O mandato foi de três anos (2012-2014) e ressaltou a importância do País em relação aos princípios já evocados anteriormente. O ECOSOC é um órgão que coordena trabalhos econômicos e sociais da ONU. Além disso, coordena também as atividades das Agências Especializadas e de outras instituições que fazem parte do Sistema das Nações Unidas (NOVAIS, 2011).

Este Conselho formula recomendações específicas e programa atividades acerca de “desenvolvimento, comércio internacional, industrialização, recursos naturais, direitos humanos, condição da mulher, população, ciência e tecnologia, prevenção do crime, bemestar social e muitas outras questões econômicas e sociais." (2011).

\subsection{O governo do Brasil: autoridade, competência e DIP}

No que concerne ao governo do Brasil, didaticamente falando, o presidente da República exerce os cargos de chefe de Estado e chefe de Governo. A Constituição da República Federativa do Brasil de 1988, no seu artigo $2^{\circ}$, aponta para os três poderes existentes: Legislativo, Executivo e Judiciário. Para Francisco Rezek, é possível que chefes de Estados presidencialistas partilhem com o Poder Legislativo a competência para resolver tratados. O ex-ministro do Supremo Tribunal Federal destaca que 
A autoridade do chefe de Estado no domínio da celebração de tratados internacionais não conhece limites: ele ostenta, em razão do cargo, idoneidade para negociar e firmar o acordo, e ainda para exprimir - desde logo, ou mediante ratificação ulterior - o consentimento estatal definitivo. Não vem à baila, neste passo, a questão constitucional doméstica (REZEK, 1998, p. 36).

Não é tão somente vontade e atitude política de manter o status econômico e social perante outros países que confere ao Brasil o reconhecimento internacional. É, também, a eficácia do Direito Internacional nas Relações Internacionais do Brasil que, apesar das dificuldades da economia, assegura o cumprimento ou pelo menos a observação do cumprimento de um objetivo de médio a longo prazo, conforme será visto posteriormente.

\section{A eficácia do Direito Internacional nas relações internacionais do Brasil no período em questão}

Celso Albuquerque de Mello considera o Direito Internacional Público - doravante chamada simplesmente como DIP - do século XX como uma nova perspectiva da personalidade jurídica, mais ampla, que considera não somente o ser humano como sujeito que atua no Direito, mas também as organizações internacionais e os Estados. Estes últimos são considerados pelo autor como os principais sujeitos do DIP (MELLO, 1990).

No entanto, o mesmo autor critica o modo como é visto o DIP nos dias atuais. Com suas ideias à frente do seu tempo, Mello enfatiza no novo olhar sobre o DIP, em 1976, no seu mais famoso livro "Curso de Direito Internacional Público", esclarecendo que

O DIP que é ensinado nas faculdades e nos livros é, ainda, via de regra, o mesmo DI formulado no século XIX pelas grandes potências ocidentais. É assim um direito que atende aos desenvolvidos e não aos países em vias de desenvolvimento (...). Deve se tornar um instrumento consagrador deste. O Direito precisa passar a ser o agente transformador da sociedade e não o consagrador de um "status quo" existente há cinquenta anos (MELLO, 1976, p.30).

Em particular, a personalidade jurídica dos Estados ganha a sua eficácia nos dias de hoje devido ao sucesso de tratados internacionais como o próprio MERCOSUL, por exemplo, que se tornou um bloco econômico. O Estado em si, nas palavras de Francisco Rezek,

É o contingente humano a conviver, sob alguma forma de regramento, dentro de certa área territorial, sendo certo que a Constituição não passa do cânon jurídico dessa ordem. A organização Internacional, de seu lado, é apenas uma realidade jurídica: sua existência não encontra apoio senão no tratado constitutivo, cuja 
principal virtude não consiste, assim, em disciplinar-lhe o funcionamento, mas em haver-lhe dado vida, sem que nenhum elemento material preexistisse ao ato jurídico criador (REZEK, 1998, p.15).

O Brasil, portanto, é um Estado de plena capacidade internacional, tendo em vista os tratados dos quais o país participou, com eficácia, sendo incluído, de fato, nas categorias de Pierre-Marie Dupuy, que são cinco no total, tendo: pleno acesso às formas de proceder nos contenciosos internacionais; pode tornar-se membro de organizações internacionais ou intergovernamentais; é capaz de estabelecer relações com outros Estados. Além disso, produz atos jurídicos internacionais e é capaz de ser imputado em fatos ilícitos internacionais. Vale ressaltar que Celso Albuquerque de Mello também vai de encontro às ideias de Dupuy.

Dessa forma, Dupuy segue aduzindo que o Direito interno e o Direito Internacional devem seguir uma harmonia, a fim de apoiar um sistema judiciário global. Defende que “L'unité d'application $d u$ droit international à l'échelle globale supposerait non la disparition, illusoire, mais à tout le moins l'estompage de la barrière entre les ordres juridiques, nationaux et internationaux"(DUPUY, sem data).

Nessa visão, o Brasil tem a missão de cumprir os tratados e compromissos globais perante outros países na questão do desenvolvimento econômico não somente pelo caráter urgente de transformação positiva dentro e fora do território nacional, mas também pelo fato de que tais objetivos transferem uma competência de gestão política tanto para os eleitores nacionais quanto para os estrangeiros, pois estes últimos tornam-se observadores de uma possível prática negligente, o que causa impressão de má imagem externa.

Existe, ainda, a perspectiva da categorização da pobreza como uma violação dos direitos humanos. A defesa pela erradicação da pobreza de Tom Campbell assim constata:

(...) é possível afirmar que agora seja a hora de pensar em utilizar sanções jurídicas, como responsabilidade civil por atitudes que, por omissão, promovam a pobreza, ou de punição jurídica, por implementar, conscientemente, políticas governamentais ou práticas empresariais que, de maneira evitável, agravem ou não façam diminuir a pobreza (CAMPBELL, 2004).

Campbell argumenta que os direitos sociais e econômicos são menos reconhecidos do que os direitos civis e políticos e que deve haver uma mudança nesse paradigma. No Brasil, ao analisar o ponto de vista de Campbell, o Direito Internacional exerce um importante papel para solucionar os conflitos políticos internos, uma vez que ajuda a traçar caminhos justos a serem percorridos. 
O Direito Internacional deve ir de encontro aos interesses e mudanças da sociedade contemporânea. As chamadas "fontes do Direito" são os sistemas que originam o sistema jurídico internacional. Sabe-se que tais fontes encontram-se no artigo 38 do Estatuto da Corte Internacional de Justiça (CIJ) das Nações Unidas, de 1945, bem como da antecessora Corte Permanente de Justiça Internacional (CPIJ-1919). Para Laura Maria Bono e Daniela Silvana Uezen Rebullida,

El Derecho en general y el Derecho Internacional, en particular, reflejan en sus normas los valores y principios que posee la sociedad que les da nacimiento, siguiendo en vigencia la expresión romana ubi societas, ibi ius. Asimismo, en el estudio del Derecho hay que tener siempre presente el marco histórico en el cual las normas nacen de la vida social (BONO; REBULLIDA, 2001).

Elas seguem afirmando que interpretar o Direito Internacional à luz do Direito Interno é um erro bastante comum, pois, de acordo com as afirmações acima, "o Direito Internacional responde à Sociedade Internacional”. Uma vez que se interpreta o Direito Internacional com as diretrizes do Direito Interno, há uma negação das peculiaridades, diferenças e, principalmente, de "plexos normativos", que cada Estado possui (2001).

Dessa forma, o Direito Internacional é imprescindível na condução das Relações Internacionais do Brasil, o que permite que a próxima parte do presente artigo mostre mais claramente as relações existentes entre Direito Internacional e Relações Internacionais do País. Apesar da incredulidade de muitos especialistas a respeito da real efetividade dos projetos e metas estabelecidos para apaziguar a alta desigualdade econômica e social, o Brasil segue na tentativa de um novo padrão de eficiência e de processo nas relações sociais, de cidadania e de democracia, que se consolidou na Constituição da República Federativa do Brasil de 1988.

\section{Relações existentes entre DIP e RI numa perspectiva brasileira (de 2004 a 2014)}

No que diz respeito à integração econômica entre as nações, vale ressaltar o princípio do inciso IX do art. $4^{\circ}$ da CRFB/88, que é o da "Cooperação entre os povos para o progresso da humanidade" . Com isso, é possível perceber a convergência do Direito interno, por meio

\footnotetext{
$6 \mathrm{O}$ art. $4^{\circ}$ da Constituição determina que: "A República Federativa do Brasil rege-se nas suas relações internacionais pelos seguintes princípios: (...) IX - cooperação entre os povos para o progresso da humanidade".
} 
da própria Constituição, com as normas e tratados internacionais. Todos vão de encontro ao objetivo específico, que é o desenvolvimento econômico.

Celso Albuquerque de Mello afirma que hodiernamente os países considerados subdesenvolvidos vem reivindicando uma "igualdade vantajosa", ou melhor, "que seja dado a eles um tratamento mais benéfico em termos de comércio, bem como de aplicação de recursos" (MELLO, 1976, p. 32).

Porém, a discussão ainda é constante, no que concerne à hierarquia de normas no DIP. Por um lado, do ponto de vista da Teoria Monista, o Direito Internacional e o Direito Interno formam somente uma ordem jurídica. Por outro lado, a Teoria Dualista debate acerca da possibilidade de o Direito interno e o DIP serem duas ordens jurídicas diferentes entre si e independentes.

É importante destacar que a Corte Permanente de Justiça Internacional (CPJI) de 1930 declarou de forma expressa a superioridade do Direito Internacional perante o Direito Interno; em 1932, a CPJI reafirma que um Estado não deve utilizar-se da sua própria Constituição para desvencilhar-se de obrigações do Direito Internacional de quaisquer tratados vigentes. Da mesma forma seguem as Organizações das Nações Unidas, em 1948, bem como o artigo $27^{\circ}$ da Convenção de Viena sobre o Direito dos Tratados de 1969.

De uma maneira geral, as Relações Internacionais na atualidade ganharam um ponto de discussão não necessariamente novo, mas reformulado: a atenção voltou-se para o desenvolvimento econômico e social dos chamados "países do Terceiro Mundo", principalmente após a Conferência das Nações Unidas sobre Meio Ambiente Humano, que ocorreu em Estocolmo, Suécia, em 1972.

Enquanto na Agenda do Norte, segundo o professor Williams Gonçalves, composta pelos países desenvolvidos, "predominava a preocupação com temas como a chuva-ácida e a poluição dos mares”, além do foco na política preservacionista, na Agenda do Sul, dos países em desenvolvimento, "predominava a preocupação com o desenvolvimento econômico-social e prevalecia a tese de que a pobreza e a miséria eram a pior forma de poluição" (GONÇALVES, 2004, p.46-47).

Dessa forma, as questões internacionais do Brasil, desde então, também vão de encontro aos tratados internacionais atuais. A principal preocupação dos países do Norte, conforme expresso acima, é diferente dos países do Sul, embora haja cooperação mútua em prol do desenvolvimento econômico-social. 


\section{Conclusão}

A escolha de um recorte temporal de 10 anos, de 2004 a 2014, acabou por conferir ao trabalho a comparação de dois governos no Brasil, especialmente nas suas Relações Internacionais e o peso inegável do DIP para o andamento contínuo das metas e compromissos estabelecidos pelo País em prol do desenvolvimento econômico.

Mas é preciso lembrar que tais metas foram ambiciosas e que, para estabelecer parceria entre os países membros da ONU, com o intuito de haver melhoria considerável da economia, reduzindo a desigualdade social, num período de quase 15 anos, deve haver um esforço “dentro de casa". Isto significa que tratados e acordos assinados devem ser observados e obedecidos, de fato, pela classe política e pela sociedade, para que haja maior eficiência possível.

No entanto, com a transição dos governos, houve um desvio de foco e a diplomacia do governo de Lula (que se esforçou para manter uma imagem de país ativo e presente no cenário internacional - como também FHC o fizera), a qual era voltada, sobretudo, para o estabelecimento de uma posição de influência do Brasil no América do Sul, retrocedeu alguns passos no governo de Dilma, embora este não tenha esquecido de seus planos mais pontuais.

Após o balanço feito entre os governos de 2004 a 2014, considerou-se ainda o fato de a ONU ter recebido a informação de que o Brasil não tinha conseguido obter pleno êxito quanto ao $8^{\circ}$ objetivo do Milênio, no assunto "desenvolvimento econômico". Dessa forma, a importância do DIP deverá ser ainda maior, a fim de reunir mais engajamento por parte do governo brasileiro. Isto serve principalmente para a agenda 2030 para o Desenvolvimento Sustentável, com seus 17 objetivos.

Neste sentido, foi importante destacar nesta presente pesquisa a relação existente entre o DIP e a Política Externa brasileira no período em questão. Sem o peso dos tratados para as diretrizes de uma política em prol do desenvolvimento econômico, seria inviável cumprir agendas, fazendo o governo voltar-se mais para a política interna e suas questões de Direito interno.

Uma das críticas realizadas ao principal acordo analisado neste artigo, que são os Objetivos do Milênio da ONU, é a de que estas metas são muito generalizadas. Estimou-se que, no futuro, houvesse claramente a elaboração de Objetivos de Desenvolvimento Sustentável (POMEROY, 2015), como de fato ocorreu.

Em 2014, mais precisamente até o dia 31 de dezembro de 2014, o Brasil não havia cumprido todos os objetivos do Milênio. Na verdade, apenas dois objetivos ganharam 
destaque, com algumas dificuldades: o objetivo número 1 (erradicar a pobreza e a fome) e; o de número 4 (reduzir a mortalidade infantil). Além disso, houve críticas acerca do oitavo objetivo, por ser esta subjetiva e sem vias de concretização.

Tal proposta, a de "desenvolver um sistema financeiro previsível e não discriminatório", "reestruturar dívidas de nações altamente endividadas e ampliar acesso a medicamentos e tecnologia" seria subjetiva, segundo alguns especialistas de Relações Internacionais. A política internacional adotada no primeiro governo de Lula, com ênfase na cooperação Sul-Sul, citada no primeiro capítulo, é alvo de críticas também (AGUIAR, 2014).

Os estudos sobre a contribuição do DIP para o planejamento de metas no Brasil, embasados principalmente por métodos quantitativos, seguem ainda rumo à garantia plena de discussão acadêmica, sem ainda possuir caminhos concretos, construídos por meio de ideias mais elaboradas e desenvolvidas.

\section{Referências bibliográficas}

BRASIL. Comissão de Direitos Humanos da Câmara dos Deputados. RELATÓRIO - O BRASIL E O PACTO INTERNACIONAL DE DIREITOS ECONÔMICOS, SOCIAIS E CULTURAIS. Brasília, DF, 2000.

BRASIL. Constituição da República Federativa do Brasil. Brasília: 5 de outubro de 1988.

CAMPBELL, Tom. A pobreza como violação dos Direitos Humanos: Justiça Global, Direitos Humanos e as Empresas Multinacionais. In: WERTHEIN, Jorge; NOLETO, Marlova Jovchelovitch (org.). Pobreza e Desigualdade no Brasil: traçando caminhos para a inclusão social. Paris: Unesco, 2004.

CERVO, Amado Luiz. Inserção Internacional: formação dos conceitos brasileiros. São Paulo: Editora Saraiva, 2008.

GARCIA, Eugênio Vargas (org.). Diplomacia Brasileira e Política Externa: documentos históricos (1493-2008). Rio de Janeiro: Contraponto, 2008.

GONÇALVES, Williams. Relações Internacionais. Rio de Janeiro: Jorge Zahar Ed., 2004. 
LACERDA, Antônio Corrêa de. (org.) Crise e Oportunidade: O Brasil e o cenário internacional. São Paulo: Editora Lazuli, 2006.

LIMA, Maria Regina Soares de; HIRST, Monica. O Brasil como país intermediário e poder regional. In: HURRELL, Andrew (et al.) Os BRICS e a ordem global. Rio de Janeiro: FGV Editora, 2009.

MELLO, Celso Albuquerque de. Curso de Direito internacional público. Rio de Janeiro, São Paulo: Biblioteca Jurídica Freitas Bastos, Vol. 1, 1976.

MELLO, Celso Albuquerque de. Curso de Direito Internacional Público. Rio de Janeiro: Editora Renovar, 2 Vol, 1990.

REZEK, José Francisco. Curso Elementar de Direito Internacional. São Paulo: Saraiva, 1998.

RICUPERO, Rubens. Esperança e Ação: a ONU e a busca de desenvolvimento mais justo: um depoimento pessoal. São Paulo: Paz e Terra, 2002.

SOUZA, Amaury de. A agenda internacional do Brasil - a política externa brasileira de FHC a Lula. Campus Elsevier: Rio de Janeiro, 2009.

Sites:

AGUIAR, Ione. A 500 dias do prazo final, Brasil só cumpriu dois dos Objetivos de Desenvolvimento do Milênio. Disponível em:

<http://www.brasilpost.com.br/2014/08/19/onu-objetivos-do-milenio_n_5689836.html>

A ONU e o Direito Internacional. In: Organização das Nações Unidas. 2014. Disponível em: <http://nacoesunidas.org/acao/direito-internacional/>

BATISTA, Paulo Nogueira. O CONSENSO DE WASHINGTON: A VISÃO

NEOLIBERAL DOS PROBLEMAS LATINO-AMERICANOS. Documentos da USP.

Disponível em: < http://www.usp.br/fau/cursos/graduacao/arq_urbanismo/disciplinas/ 
aup0270/4dossie/nogueira 94/nog94-cons-washn.pdf>

BONO, Laura Maria; REBULLIDA, Daniela S. U. El concepto de civilización en el Derecho Internacional. In: Revista Eletrônica do Tempo Presente (TEMPO - UFRJ) - ano 05, no 01. ISSN 1981-3384. Disponível em:<http://www.tempopresente.org/attachments/ article/5921/Ano\%2005\%20-\%20N\%C3\%BAmero\%2001\%20-\%20Artigo\%2001.pdf>

\section{COMPROMISSO COM A MUDANÇA - DOCUMENTOS HISTÓRICOS DO}

PT. 2002. Disponível em: http://www.pt.org.br/portalpt/images/stories/arquivos/ compromissocomamudanca.pdf

DUPUY, Jean-Marie. Unité d'Application du Droit International à l'Echelle Globale et Responsabilité des Juges. IN: European Journal of Legal Studies. Disponível em: $<$ http://www.ejls.eu/2/21FR.pdf >

Grupo de Reflexão de Relações Internacionais; POMEROY, Melissa (org.). In: Qual desenvolvimento teremos a partir de 2015? Disponível em: <http:/www.cartacapital.com.br/ blogs/blog-do-grri/a-agenda-pos-2015-nocoes-de- desenvolvimento-em-disputa4328.html>

NOVAIS, Djalma. Qual a importância da atual eleição do Brasil ao Conselho Econômico e Social das Nações Unidas (ECOSOC)? Portal de Comércio Exterior - Disponível em: $<$ http://dla.com.br/comexnews/ 2011/10/26/qual-a-importancia-da-atual-eleicao-do-brasil-ao- conselho-economico-esocial-das-nacoes-unidas-ecosoc/>

ROUSSEFF, Dilma. Discurso da LXVI Sessão Ordinária da Assembleia Geral da ONU (Nova York, setembro de 2011). In: SOUZA, André L. C. F. de; SANTOS, Vinícius Silva dos. A análise da política externa do governo Dilma Rousseff na perspectiva dos pronunciamentos oficiais na ONU. Revista Mural Internacional. Universidade Federal do Estado do Rio de Janeiro - UNIRIO. Vol. 5, n. 02, Jul-Dez 2014. Disponível em: < http://www.unirio.br/ccjp/cienciapolitica/arquivos-1/discursos-dedilma> 
VEIGA, Pedro da Motta; RIOS, Sandra Polónia. Política Econômica Externa do

governo Dilma: dilemas e desafios. In: Revista Pontes. Abril/ Maio -2011. Vol. 07. N. 1.

Disponível em: <http://www.ictsd.org/downloads/pontes/pontes7-1.pdf>

http://www.pnud.org.br/odm.as

px

http://www.un.org/en/ecosoc/ 


\title{
RAÍZES HISTÓRICAS E PERSPECTIVAS DOS DESAFIOS POLÍTICOS E DIPLOMÁTICOS IMPOSTOS À INTEGRAÇÃO REGIONAL SUL-AMERICANA
}

\author{
William Paiva Marques Júnior \\ UFC (Universidade Federal do Ceará)
}

\begin{abstract}
Resumo
O ideal integracionista sul-americano só se torna possível com a superação dos problemas comuns, vontade política e diplomática, bem como a necessidade de participação democrática das populações envolvidas. Utiliza-se, como metodologia, de pesquisa do tipo bibliográfica por meio da análise de livros, artigos jurídicos, documentos internacionais, da legislação e da jurisprudência. A pesquisa é pura e de natureza qualitativa, com finalidade descritiva e exploratória.
\end{abstract}

Palavra-chave: desafios, política, diplomacia, integração regional, América do Sul.

\section{Abstract/Resumen/Résumé}

The integrationalist model of South America is only possible with the overcoming of common problems, political and diplomatic will, as well as the need for democratic participation of the populations involved. It is used, as methodology, of research of the bibliographic type through the analysis of books, legal articles, international documents, legislation and jurisprudence. The research is pure and qualitative, with a descriptive and exploratory purpose.

Keywords/Palabras-claves/Mots-clés: challenges, policy; diplomacy, regional integration, South America.

\section{Introdução}

A análise histórica do processo integracionista da América do Sul revela uma região complexa, com profundas diversidades étnicas, culturais e religiosas (bases dos paradigmas de interculturalidade e plurinacionalidade, experiência hoje consagrada pelo Novo Constitucionalismo Democrático Latino-Americano), que suscita questionamentos acerca das 
enormes desigualdades sociais e econômicas que se refletem em uma contínua instabilidade política, intercalada por ciclos de regimes ora democráticos e em outros momentos, autoritários.

A formação histórica do processo de integração regional da América do Sul remonta ao período de colonização dos portugueses e dos espanhóis a partir do Século XVI e implicou na formação de uma epistemologia informada pela imposição de valores europeus para a realidade do Sul que implicaram em uma dificuldade de superação dessa lógica de subalternidade através da construção de um modelo próprio, para além da mera subsunção do modelo integracionista nos moldes europeus. A reconstrução da ordem jurídica, econômica, política e social após o declínio dos regimes ditatoriais que marcaram o século XX na região sul-americana implicou no fortalecimento no projeto de integração.

A presença de um sistema político-institucional corrupto, clientelista e pouco transparente, bem como a profunda desigualdade socioeconômica nos países da América do Sul acarreta na perda da legitimidade para o êxito do processo de integração regional, que se acelerou a partir do Século XX com a criação da CEPAL, mas remonta ao Século XIX. Faz-se necessária a superação desses problemas para a efetividade do projeto integracionista sulamericano.

\section{Construto histórico da integração sul-americana nos séculos XIX e XX: da Guerra do Paraguai aos projetos diplomáticos}

Conforme esposado com Elizabeth Meirelles (2008, págs. 161 e 162) diversos políticos e diplomatas são apontados como sendo os "pais" do ideal pan-americanismo, antes mesmo de iniciado o processo de independência das colônias na América, no século XIX. Entre eles, alguns incluem o brasileiro Alexandre de Gusmão, pela defesa das posições ditas "americanas" no Tratado de Madrid, de 1750 (embora estas fossem sobretudo de interesse das Coroas espanhola e portuguesa) e o peruano Pablo de Olavide que, em 1795, criou em Madrid uma sociedade secreta visando estimular a independência das "cidades" e províncias da América meridional. Podem ser entrevistas na raiz do desenvolvimento do ideal pan-americano as contribuições dos chilenos Juan Martínez de Rosas e Bernardo O’Higgins e os argentinos Jose de San Martín e o Coronel Monteagudo, que tiveram participação ativa nas guerras de libertação não apenas do seu país, mas igualmente, do Chile e do Peru, e propuseram a realização de um Congresso continental. Simon Bolívar é claramente o mais famoso e um dos mais ardorosos defensores da integração latino-americana. Ainda quando estava em seu exílio no Caribe, o líder da independência hispano-americana conclamou, na Carta da Jamaica (1815), 
a criação de três federações na América Latina: uma reunindo o México e a América Central, a segunda, abrangendo o norte da América do Sul e a terceira, o sul do continente. Posteriormente, em 1826, durante a realização do Primeiro Congresso Americano, no Panamá, esta ideia se aprofundaria em um projeto político mais amplo, desta vez de caráter continental. De imediato, surgiu em 1819, a Grã-Colômbia, que perdurou até 1830, quando, do seu desmembramento, surgiram a Venezuela, o Equador e a Colômbia, que abrangia também o Panamá. As tentativas de Bolívar de unir a este grande Estado latino o Peru e a Bolívia esbarrariam no acentuado regionalismo das suas lideranças.

Paulo Bonavides (2011, p. 57/58) identifica a existência de três fases ou períodos históricos da unidade latino-americana: (1) a primeira, vem desde Bolívar e Monroe, sendo a fase utópica em que o princípio povoa de sonhos de liberdade e cooperação fraternal a cabeça dos construtores de nossa emancipação política. Durante lergas décadas, ao longo do século XIX, o pan-americanismo foi, simplesmente, tese, ideia, declaração de princípios, aspiração de unidade; (2) a segunda fase, denominada "jurídico-institucional”, principia em fins do século XIX, com a antiga União Pan Americana. Corresponde ao extenso período das primeiras conferências pan-americanas, desdobrando-se até 1958, ano da Operação Pan-americana do então Presidente do Brasil, Juscelino Kubitscheck. Aí, o hemisfério, empregando penosos esforços, realiza a obra de união jurídica, que se perfaz em tratados de mútua assistência e solidariedade; (3) a terceira fase, ora vivenciada é menos acadêmica que as antecessoras. Caracteriza-se, sobretudo, pelo seu teor ideológico-desenvolvimentista, tendo sido inaugurada com a carta histórica que aquele ex- Presidente brasileiro, a 38 de maio de 1958, endereçou a Eisenhower, então Presidente dos Estados Unidos, e deste obteve, oito dias depois, resposta afirmativa.

As Conferências Pan-Americanas, que materializaram o movimento pan-americanista, não obtiveram adesão dos países idealizados e não conseguiram consolidar nenhum projeto duradouro o que consagrou o isolacionismo das nações recém- criada no século XIX e por longas décadas do século XX.

Sobre o projeto bolivariano de integração anotam Luiz Felipe Viel Moreira, Marcela Cristina Quinteros e André Luiz Reis da Silva (2010, págs. 47 e 48) que em 1823, a Grande Colômbia tinha assinalado a urgência de criar uma confederação para resistir ao provável avanço das potências europeias. Com isso, ficaram enunciados os princípios básicos dessa confederação: respeito às soberanias nacionais e a não intervenção de potências estrangeiras. $\mathrm{O}$ convite foi extensivo à Grã-Bretanha, como membro constituinte, cuja presença era importante para garantir a sobrevivência econômica e política de uma futura confederação. Segundo o 
pensamento bolivariano, as soberanias nacionais deviam ser respeitadas e a confederação seria formada para garantir a segurança do continente, obter o reconhecimento das independências por parte da Espanha e promover a igualdade entre seus integrantes. Nos fatos, era quase impossível efetivar o projeto de defesa conjunta do subcontinente latino-americano, quando as nações mal conseguiam manter a unidade interna e as comunicações, que na primeira metade do século XIX eram extremamente difíceis e demoradas e, em algumas regiões, inexistentes e inviáveis no médio prazo. Porém, o projeto de formar uma aliança subcontinental permanece para a defesa de seus interesses econômicos, políticos e militares manteve-se até os dias atuais, sendo o Congresso do Panamá a referência de muitos líderes latino-americanos que se apropriaram, de diversas maneiras, da figura simbólica de Bolívar.

O pan-americanismo caiu em desuso após tentativas frustradas de Simón Bolívar de torná-lo realidade nos congressos continentais de 1819 e 1826. Em um momento histórico posterior, porém, durante a segunda metade do século XX o ideal de união latino-americana foi denominado de "integração regional” e incorporado em organizações como a CAN, o MERCOSUL e mais recentemente, a UNASUL. Estes são blocos que encontram-se um constante processo de avanços e retrocessos, sem que se possa concluir definitivamente que se trata de uma derrota ou uma vitória.

De acordo com Leandro Rocha de Araújo (2008, pág. 114), a integração na América Latina é um tema que se confunde com o próprio processo de formação histórica dos países latino-americanos. Desde o início do Século XIX, diversos foram os movimentos de independência que se espalharam por toda a América Latina, os quais foram seguidos por: (I) consolidação da independência dos Estados americanos; (II) um sentimento de solidariedade continental, a fim de manter a paz nas Américas; e (III) um estímulo à inter-relação entre os países da América Latina.

A Guerra do Paraguai representou um marco significativo e indelével na história da política exterior da América do Sul, notadamente para a diplomacia brasileira, cuja evolução histórica desconhece muitos fenômenos bélicos, principalmente quando se analisa em cotejo com outras regiões do mundo. No plano interno brasileiro, o período posterior à Guerra do Paraguai foi de ascensão e consolidação das Forças Armadas e a consequente queda do regime sócio-político escravocrata e imperial em fins do Século XIX.

Apesar de todas as divergências históricas interpretativas sobre a motivação primacial da Guerra do Paraguai, observa-se que a causa determinante do conflito foi a pretensão de domínio hegemônico regional. Brasil, Argentina, Uruguai e Paraguai forjaram uma disputa territorial com o intuito de emergirem na ordem pós-colonial. 
Na opinião de Sérgio Buarque de Holanda (1995, págs. 177), o Brasil recorreu à guerra não por ambição de conquista, mas sim para fazer-se respeitar perante os países platinos.

De acordo com Boris Fausto (2010, págs. 117 e 118), as relações do Brasil com o Paraguai, na primeira metade do Século XIX, dependeram do estado das relações entre Brasil e a Argentina. Quando as rivalidades entre os dois países aumentavam, o governo imperial tendia a aproximar-se do Paraguai. Quando a situação se acomodava, vinham à tona as diferenças entre o Brasil e o Paraguai. As divergências diziam respeito a questões de fronteira e à insistência brasileira na garantia da livre navegação pelo Rio Paraguai, principal via de acesso a Mato Grosso. Aparentemente, as possibilidades de uma aliança Brasil-ArgentinaUruguai contra o Paraguai e, mais ainda, uma guerra com esse tipo de configuração pareciam remotas. Mas foi o que ocorreu. A aproximação entre os futuros aliados ocorreu em 1862, quando Bartolomé Mitre chegou ao poder na Argentina, derrotando os federalistas. O país foi reunificado sob o nome de República Argentina e Mitre foi eleito presidente. Ele começou a realizar uma política bem vista pelos liberais brasileiros que haviam assumido o governo naquele mesmo ano. Aproximou-se dos "colorados" uruguaios e se tornou um defensor da livre negociação entre os rios. Esses acertos deram espaço para as rivalidades entre Brasil e Paraguai.

Houve perdas para todos os países envolvidos, mas para o Paraguai, a derrota na guerra foi mais danosa. O conflito havia levado à morte da maioria da população do país, em especial a masculina, em que pese a inexistência de dados censitários seguros. A economia paraguaia sofreu um revés que implicou no fortalecimento da agricultura como a atividade primária do país.

A guerra gerou um pesado endividamento do Paraguai com o Brasil. Essa dívida foi perdoada em 1943 durante o Estado Novo de Getúlio Vargas, quando da assinatura de tratados com o então presidente paraguaio Higinio Morínigo. Mas os encargos da guerra e as necessidades de recursos financeiros levaram o país à dependência de capitais estrangeiros.

$\mathrm{Na}$ análise de Amado Luiz Cervo e Clodoaldo Bueno (2010, pág. 123) a guerra foi financiada com recursos do Tesouro brasileiro, que repassou grandes empréstimos à Argentina, e com recursos de banqueiros ingleses, interessados apenas em transações rentáveis, mesmo à revelia do governo de Palmerston. Este não teve responsabilidade alguma sobre a origem ou sobre o andamento das operações, bem contava aqui com "vassalos", dispostos a executar seus desejos. A guerra foi desencadeada por López, e sua condução foi sim resultado da vontade de Estado, brasileira em primeiro lugar e argentina em segundo. Foi uma determinação do governo brasileiro eliminar López, como fez com Rosas no passado. Daí o prolongamento da guerra, que se tornou desde cedo impopular tanto no Brasil quanto no Prata. Sustentavam-na 
interesseiramente os que dela se beneficiaram: fornecedores, comerciantes, atravessadores e o próprio Mitre, que recebia recursos volumosos com que equilibrava suas combalidas finanças públicas e liquidava a oposição interna.

A Guerra do Paraguai afetou o Brasil em muitos aspectos. Sob o viés econômico, o conflito gerou muitos encargos monetários que só puderam ser sanados com empréstimos estrangeiros, o que fez aumentar a dívida externa e a dependência nacional em relação às grandes potências da época, notadamente a Grã-Bretanha.

Conforme assevera José Murilo de Carvalho (2009, págs. 37 e 38), as guerras são fatores importantes na criação de identidades nacionais. A do Paraguai teve sem dúvida esse efeito. Para muitos brasileiros, a ideia de pátria não tinha materialidade, mesmo após a independência. Existiam no máximo identidades regionais. A guerra veio a alterar essa situação. De repente havia um estrangeiro inimigo que, por oposição, gerava o sentimento de identidade brasileira. São abundantes as indicações do surgimento dessa nova identidade, mesmo que ainda em esboço. Podem-se mencionar a apresentação de milhares de voluntários no início da guerra, a valorização do hino e da bandeira, as canções e poesias populares.

No âmbito das relações regionais da América do Sul, como resultado do conflito, o Brasil estimulou a sobrevivência do Paraguai como nação independente uma vez que assinou separadamente um tratado de paz com o Paraguai em 1872. Como resultado o governo imperial brasileiro conseguiu confirmar as fronteiras que eram reivindicadas antes de a guerra começar, ao passo que a Argentina, nutria o desejo de absorver a nação paraguaia. Corrobora neste sentido o fato de que a Argentina não reconheceu a independência do Paraguai no mesmo momento em que o Brasil o fez, tal fato só ocorreu em 1876 por ocasião da Conferência de Buenos Aires, que estabeleceu a paz no continente sul-americano.

Existe consenso na historiografia tradicional que a vencedora absoluta da Guerra do Paraguai foi a grande potência colonial do Século XIX: a Inglaterra. Com a derrota bélica e o massacre humano e econômico paraguaio, a monarquia britânica consolidou a hegemonia sobre a América do Sul. O Paraguai se tornou mais um consumidor de seus produtos. Argentina, Brasil e Uruguai tornaram-se ainda mais dependentes da Grã-Bretanha na medida em que aumentaram suas dívidas com o então império político hegemônico do Século XIX.

De acordo com a versão tradicional, houve um genocídio que perpetuou o atraso econômico paraguaio até os dias de hoje. À luz do revisionismo histórico, no entanto, afirmase que a Guerra não foi resultado único da atuação do governo britânico, mas sim uma fase importante do processo de construção das identidades regionais na região do Cone Sul, tampouco houve genocídio (intenção deliberada de destruição, total ou parcialmente de grupo 
nacional, étnico, racial ou religioso). De acordo com as análises mais recentes, a responsabilidade pela deflagração da Guerra do Paraguai ateve-se às questões regionais, tais como as frequentes disputas por áreas fronteiriças e a intervenção brasileira no Uruguai (o que interferia no escoamento da produção paraguaia pelo porto de Montevidéu), bem como da agressão inicial realizada pelo Governo Paraguaio. Hoje se entende que a Guerra poderia ser evitada (inclusive com a comprovação de que a diplomacia britânica interferiu no sentido da paz), mas não havia como o Brasil afastar-se do conflito bélico uma vez que o contexto brasileiro revelava que a região do Rio da Prata era a porta de entrada para a então longínqua Província do Mato Grosso. A análise historiográfica realizada na contemporaneidade também desmitifica a ideia de que o Paraguai era uma potência (quer em nível regional ou mundial, como se chegou a afirmar em diversos momentos). Atualmente se entende que o Paraguai no momento anterior à Guerra era um país predominantemente agrário, que contava com uma industrialização incipiente, no qual as condições de vida da maioria da população eram bastante ruins. Dentro desse contexto torna-se impossível acreditar que a o Paraguai representasse uma ameaça efetiva ao imperialismo inglês no continente sul-americano. Ademais não se pode culpar exclusivamente a Guerra do Paraguai como causa determinante para o atraso econômico da nação referenciada nos séculos subsequentes.

Na análise de Francisco Doratioto (2012, págs. 20 e 21), com a Guerra do Paraguai terminava o longo, complexo e sangrento processo de construção e definição dos Estados nacionais na América do Sul. O Estado autocrático paraguaio foi destruído e substituído por um modelo liberal, que persistiu até 1936, em uma sociedade sem burguesia e que, em consequência da destruição causada pela guerra, carecia de sistema produtor de riquezas primárias.

Para Samuel Pinheiro Guimarães (2007, pág. 116), a estratégia política americana na América Latina tem como principal objetivo manter e preservar a Doutrina Monroe e estruturar um organismo hemisférico que legitime as intervenções militares americanas, quando estas se fizerem necessárias. Em segundo lugar, os Estados Unidos procuram com persistência alinhar a política externas dos países latino-americanos com a sua e contar com o apoio desses países para suas iniciativas nos organismos internacionais ou fora deles. Em terceiro lugar, sua estratégia procura manter regimes, democráticos ou não, que garantam a liberdade de ação dos interesses americanos e promovam a adoção das normas chamadas de good governance.

Não se pode olvidar que a América do Sul foi por muito tempo um verdadeiro apêndice da hegemonia inglesa e após a decadência do império britânico, tornou-se campo propício à 
influência norte-americana, como corolário da adoção da Doutrina Monroe (“América para os americanos").

Para Luciane Klein Vieira (2011, pág. 1), a necessidade de os Estados se agregarem em regiões tem dado origem a muitos esquemas de integração diferentes, que são agora uma realidade criada pelo processo de globalização, presente há muito tempo no cotidiano da humanidade. Na atualidade, atuar em grupo é uma condição que se impõe naturalmente aos Estados, se estes, como atores políticos quiserem permanecer competitivos no mercado internacional.

Conforme aduzem Amado Luiz Cervo e Clodoaldo Bueno (2010, págs. 486 e 487), as relações entre o Brasil e seus vizinhos responderam a apelos históricos contraditórios: isolamento, boa vizinhança, liderança. Imagens e percepções dos dois lados condicionaram a estratégia regional. Também as afinidades e diferenças. A Argentina, rival diminuída, disputou com o Brasil a influência sobre Uruguai, Paraguai e Bolívia. O Brasil contou historicamente com o Chile e, desde o Tratado de Cooperação Amazônica de 1978, com os países amazônicos. A confiança mútua engendrada nas relações com a Argentina recuperou a ideia de Rio Branco de liderar a América do Sul em sintonia com esse vizinho maior, se possível. Desde o início da década de 1990, o Brasil traçou uma estratégia regional que permaneceria invariável: reforço do MERCOSUL com convergência política entre Brasil e Argentina e organização do espaço sul-americano com autonomia perante os Estados Unidos.

No diagnóstico de com Leandro Rocha de Araújo (2008, pág. 116), essa crescente diferenciação entre os países americanos, inclusive os latino-americanos, dificultou o almejado processo de integração. Cabe destacar que, mesmo em âmbito mundial, a integração efetiva entre os diversos países não havia se desenvolvido até a década de 1940. Somente após o desfecho da Segunda Guerra Mundial é que os países passaram a procurar formas de evitar as consequências negativas das políticas protecionistas do início da década de 1930, promovendo um movimento de busca de maior integração.

Durante as primeiras três décadas após o desfecho da Segunda Guerra Mundial, os esforços integracionistas na América Latina eram promovidos quase exclusivamente por equipes de burocratas e alguns membros das elites econômicas, que eram capazes de funcionar sem dar atenção à oposição pública (essencialmente proletária), uma vez que nessa época a maior parte da região estava submetida aos regimes ditatoriais e liberticidas. Ao final dos anos 1980, porém, a América do Sul abandonou o seu passado autoritário. Hoje, toda a região é governada por regimes democraticamente eleitos, mesmo que a profundidade e estabilidade da democracia em vários países sejam uma questão ainda fluida e sujeita a algumas surpresas 
negativas. O apoio popular ao êxito do projeto integracionista é fundamental, mas em contrapartida os cidadãos querem verificar as vantagens sociais, econômicas, políticas e culturais desse longo projeto.

Mostra-se necessário esclarecer que, em sua gênese, o processo de industrialização da América do Sul mostrou-se concentrador e excludente. O processo atual de desenvolvimento regional requer a necessidade de garantia aos cidadãos locais da possibilidade de superarem a pobreza sendo que, para tanto, devem ser promovidos mecanismos de concretização dos direitos fundamentais, sendo esta uma das principais estratégias de inclusão individual e transformação social.

Conforme aduzem Bernardo Sorj e Danilo Martuccelli (2008, págs. 208 e 209), na frente interna, a formação do sistema industrial durante a fase nacional-populista cumpriu um papel notável na consolidação da autonomia estatal. A expansão da máquina burocrática, propiciada pela industrialização, permitiu a ampliação da plataforma legal e institucional dos Estados, conferindo-lhes densidade nacional. Por isso, em países onde o processo de industrialização foi pouco intenso ou simplesmente não decolou, a estrutura burocrática se atrofiou, e o Estado, mais vulnerável à ação predatória de interesses privados, careceu de base social capaz de sustentá-lo nacionalmente.

Verifica-se um consenso político histórico que prioriza um processo de integração autêntico e mais profundo e que significa ampliar as relações em todos os seus aspectos, sejam eles políticos, sociais, econômicos e culturais e de forma não apenas intergovernamental (como é o caso do MERCOSUL).

Essa etapa da consciência latino-americana ocorre a partir de uma estratégia econômica que alcança a primeira expressão institucional com a CEPAL (Comissão Econômica para a América Latina e o Caribe, criada em 1948) e com a criação do Banco Interamericano de Desenvolvimento - BID em 1959, o que demonstra que as iniciativas integracionistas na América do Sul são um processo contínuo que se desenvolve há décadas.

A Comissão Econômica para a América Latina e o Caribe (CEPAL) foi criada em 25 de fevereiro de 1948, pelo Conselho Econômico e Social das Nações Unidas (ECOSOC), e tem sua sede em Santiago, Chile. A CEPAL é uma das cinco comissões econômicas regionais das Nações Unidas (ONU). Foi criada para monitorar as políticas direcionadas à promoção do desenvolvimento econômico da região latino-americana, assessorar as ações encaminhadas para sua promoção e contribuir para reforçar as relações econômicas dos países da área, tanto entre si como com as demais nações do mundo. Posteriormente, seu trabalho ampliou-se para os países do Caribe e se incorporou o objetivo de promover o desenvolvimento social e 
sustentável. Em 1996, os governos-membros atualizaram sua missão institucional, estabelecendo que a Comissão deve desempenhar-se como centro de excelência, encarregado de colaborar com seus Estados-membros na análise integral dos processos de desenvolvimento. Esta missão inclui a formulação, seguimento e avaliação de políticas públicas e a prestação de serviços operativos nos campos da informação especializada, assessoramento, capacitação e apoio à cooperação e coordenação regional e internacional. Todos os países da América Latina e do Caribe são membros da CEPAL, junto com algumas nações desenvolvidas, tanto da América do Norte como da Europa, que mantêm fortes vínculos históricos, econômicos e culturais com a região. A proposta economicista fundamentava-se na liberalização de mercados pela criação de zonas comerciais cujos processos foram deflagrados pelo Mercado Comum Centro-Americano (MCCA) e pela Associação Latino-Americana de Livre Comércio ALALC, ambos de 1960.

No século XX, o maior impulso de integração latino-americana, ocorreu no fim dos anos cinquenta, como um reflexo dos esforços de integração realizados na Europa, com a assinatura do Tratado de Roma. Quatro acordos regionais datam daquela época: a Associação Latino-Americana de Livre Comércio (ALAC); o Mercado Comum Centro-Americano (MCCA); a Associação de Livre Comércio do Caribe (CARICOM), e o Pacto Andino (1969). Todos estes esforços de integração seguiram, em grande medida, o mesmo padrão de evolução: a princípio, ajudaram a expandir consideravelmente o comércio exterior entre seus signatários; porém, em geral, sofreram uma estagnação no início dos anos oitenta.

Consoante o diagnóstico de Antonio José Ferreira Simões (2011, pág. 68), a clivagem entre "comercialistas", posição com a qual o Brasil se identificou, e "desenvolvimentistas", uma visão que era, sobretudo, dos países andinos, que esperavam criar com a ALALC condições para o seu desenvolvimento industrial, geraria ao longo dos anos tensões crescentes para viabilizar os objetivos originais da organização. Outro problema que viria a afetar a eficácia da ALALC era o fato de que não representava para o Brasil, nem para vários de seus membros, um projeto nacional, mas mero instrumento de apoio ao processo de substituição de importações, dentro de uma realidade econômica autárquica.

A Comunidade Andina (CAN) é um bloco econômico formado por Bolívia, Colômbia, Equador e Peru. O Chile deixou o bloco em 1977 e a Venezuela em 2006. O Acordo de Cartagena (1969) foi o documento que deu origem à Comunidade Andina. A evolução do MERCOSUL e da CAN serviram de plataforma inicial do processo de criação da UNASUL.

Nas tratativas que redundaram na criação do MERCOSUL um importante contributo que definiria novas linhas de arranjos internacionais foi representado pelas tratativas 
entabuladas empreendidas pelos então presidentes do Brasil, José Sarney e Raúl Alfonsín, da Argentina, em fins da década de 1980, que resultaram na assinatura do Tratado de Assunção em 1991, e o nascimento do Mercado Comum do Sul.

Conforme expõe Samuel Pinheiro Guimarães (2005, págs. 378 e 379), ao se iniciar o processo de cooperação e integração econômica entre Brasil e Argentina, em 1985, havia nos governos Alfonsín e Sarney a compreensão de duas questões: a primeira, de que esse era um processo político; e a segunda, de que era uma iniciativa necessária à defesa dos interesses econômicos e políticos da Argentina e do Brasil, em um sistema internacional cada vez mais competitivo, agressivo e concentrador em todos os seus aspectos. Os princípios fundamentais desse processo foram definidos como gradualismo, equilíbrio, flexibilidade e participação social. Procurou-se, então, construir os programas específicos de tal forma que pudessem ser implementados e não viesse a se transformar em meras manifestações de intenção.

O MERCOSUL surgiu do amadurecimento das relações entre o Brasil e a Argentina a partir dos anos 1980 que superaram diversas assimetrias que se prolongavam historicamente e ganhou dimensão relevante no contexto da consolidação da democracia e de suas instituições, da estabilização monetária, da suplantação dos períodos inflacionários e do diálogo crescente com o sistema internacional.

Para alcançar-se o êxito na materialização do MERCOSUL, Brasil e Argentina também tiveram que superar controvérsias no campo energético, principalmente no que tange às represas hidrelétricas do alto Paraná (Itaipu e Corpus). A partir de 1979, os dois países decidiram executar um Programa de Integração e Cooperação Econômica (PICE), pautando-se por parâmetros de gradualismo, flexibilidade e equilíbrio. Essa decisão política foi necessária pelo Brasil, que em período de crise econômica necessitava adquirir trigo e petróleo da Argentina, o que serviu como iniciativa para um esforço de complementação.

Sob o prisma institucional, o MERCOSUL foi precedido pelo Programa de Integração e Cooperação Econômica entre a Argentina e o Brasil (PICE), lançado em de 1986, que apresentava como escopo a integração gradual dos países detentores das duas maiores economias do subcontinente. Em 1988, o processo foi acelerado com a assinatura do Tratado de Integração, Cooperação e Desenvolvimento, que estabelecia um prazo máximo de dez anos para se atingir uma zona de livre-comércio, a harmonização gradual das políticas setoriais e a coordenação das políticas macroeconômicas. O Artigo 2 do Tratado referenciado estabelecia que o processo seria aplicado conforme os princípios de gradualismo, flexibilidade, equilíbrio e simetria. 
A segurança jurídica necessária à integração dos países da América do Sul dependerá das condições de democracia e da qualidade desta nos diversos países que a buscam. O chamado "déficit democrático" é uma realidade constante na evolução política dos países latinoamericanos permeada por ditaduras militares e sucessivos golpes de Estado. A realidade democrática sul-americana consolida-se definitivamente a partir das décadas de 1980 e de 1990 . Atualmente, os países da América do Sul constituem-se formalmente em Repúblicas presidencialistas, cuja ordem política cumpre os requisitos básicos do valor democrático.

De acordo com Florisbal de Souza Del'Olmo e Eduardo Daniel Lazarte Moron (2018, online), no contexto latino-americano, observa-se que a tendência de formação de espaços de relações privilegiadas entre países, por meio de projetos de integração comercial, incluindo a formação de blocos econômicos regionais, não é recente e configura elemento central nos esforços depreendidos pelos governos locais com vistas a promover uma melhor inserção dos Estados da região no mercado internacional.

A influência exacerbada do aspecto econômico sobre o processo de integração europeu pode ser substituída por outros parâmetros no modelo sul-americano, tais como o meio ambiente, as águas, a infra-estrutura, o efetivo compromisso na redução das assimetrias regionais e a energia.

\section{Desafios políticos, sociais e econômicos impostos às perspectivas de efetividade da integração da América do Sul}

A realidade contemporânea dos países americanos (mormente os da América do Sul), demonstra a existência de fatores diversos que desafiam a integração regional, como: a corrupção institucionalizada; as carências na infraestrutura (ausência de rotas aéreas diretas entre as principais cidades, inexistência de ferrovias e rodovias adequadas, subaproveitamento do sistema aquaviário, sistema energético não integrado, tecnologia portuária e aeroportuária bastante obsoleta); carência no acesso à água potável e ao saneamento básico (em algumas regiões, a escassez é crônica e se prolonga há vários séculos); as profundas desigualdades sociais e econômicas; o poder paralelo do narcotráfico e a estrutura do crime organizado em âmbito transnacional; violência urbana e constantes violações aos direitos humanos; as vicissitudes ambientais (poluição do ar e da água, desmatamento das florestas, utilização de técnicas agrícolas devastadoras à vida...); baixos níveis educacionais; deficiência no acesso à saúde; frequentes práticas arbitrárias e ilegais 
dos Estados ante os seus cidadãos; dentre diversas outras questões que devem ser enfrentadas para o êxito do bem- estar do ser humano, primordial na efetividade do paradigma do buen vivir, um dos pilares fundantes do Novo Constitucionalismo Democrático LatinoAmericano.

As novas iniciativas de integração da América do Sul e da América Latina demonstram que há um esforço no sentido de aprofundar as relações regionais e superar em conjunto os problemas estruturais, na maioria das vezes similares, que enfrentam os países latino-americanos.

Um dos fatores que obstaculizam a implementação da integração sul-americana é o défice histórico no campo da infraestrutura, criando verdadeiras nações fundadas no solipsismo das soberanias internas, em detrimento de um projeto de integração baseado na lógica da harmonia, da solidariedade e da complementaridade.

A importância do setor empresarial revela-se ainda mais evidente em face da necessidade de superação dos problemas em matéria de infraestrutura. Um exemplo pode ser explicitado no que se refere à premência de estabelecimento de conexão das malhas energéticas dos países sul-americanos. Isso pode ser constatado, por exemplo, ao se analisar a atual crise energética que limita o crescimento econômico da Argentina e ocasiona sérios prejuízos à Venezuela, ao tempo em que os vizinhos deste país, tais como o Paraguai e o Brasil, dispõem de reservas energéticas que poderiam, pelo menos, amenizar a situação crítica enfrentada pelos argentinos, não fossem as deficiências de infraestrutura energética da região.

Outra barreira a ser transplantada para o êxito do projeto integracionista é a necessidade de superação da diretriz protecionista das políticas econômicas internas dos países sul-americanos. Neste aspecto, o protecionismo ultrapassa as questões econômicocomerciais para tocar a esfera político-cultural. Quebrar este paradigma talvez seja o maior desafio não somente para a UNASUL, mas também para todos os blocos que miram a integração. A transposição dos obstáculos para a concretização do acordo não será simples tarefa. Ao Brasil e aos demais membros do bloco sul-americano cumpre reforçar seus ideais de solidariedade e de cooperação, com a adoção de medidas que valorizem seus produtos. Faz-se necessária uma mobilização político-diplomática concreta dos Estados para responder às demandas e exigências do mercado integrado.

$\mathrm{O}$ acesso à educação das populações dos países sul-americanos exerce função primordial na determinação do apoio ao êxito dos projetos integracionistas. Verificam-se duas importantes variáveis socioeconômicas, diretamente relacionadas ao apoio popular à 
integração sul-americana: os benefícios percebidos dos blocos comerciais regionais e a percepção da situação econômica pessoal e nacional. Isso sugere que os benefícios vivenciados pelo povo ensejam o sucesso, e quanto mais o subcontinente prosperar com o comércio regional e sua economia florescer, propiciando bem-estar à coletividade, tanto maior será a adesão popular à proficuidade da integração regional. Se a região aprimorar o seu caminho de crescente democratização, isso significará um apoio crescente à integração.

Uma América do Sul unida pelos mecanismos engendrados pela UNASUL tende a alterar a arena das relações internacionais na contemporaneidade, ao mesmo tempo em que plasmaria um ideal secular de integração regional, bem como enfrentaria os entraves que se arrastam historicamente na região. Com isso, torna-se possível enfrentar as vicissitudes vivenciadas regionalmente: o narcotráfico, a violência, a burocracia e a corrupção, constituem alguns problemas congênitos da região. Mesmo este organismo sendo multipolar, é necessária a proeminência de alguma nação, local que o Brasil deve aproveitar estrategicamente para se reafirmar definitivamente como potência regional, inserido em uma conjuntura de região ambientalmente pujante, estável economicamente e democrática na esfera política (apesar de todas as instabilidades).

Diversos problemas regionais, como narcotráfico e crime organizado transnacional, são enfrentados no objetivo específico constante no Art. $3^{\circ}$-, alínea "q" do Tratado Constitutivo da UNASUL, ao prever a coordenação entre os organismos especializados dos Estados-membros, levando em conta as normas internacionais, para fortalecer a luta contra o terrorismo, a corrupção, o problema mundial das drogas, o tráfico de pessoas, o comércio ilícito de armas pequenas e leves, o crime organizado transnacional e outras ameaças, assim como para promover o desarmamento, a não proliferação de armas nucleares e de destruição em massa e deminagem.

Constituem-se em desafios à efetividade da integração regional sul-americana os altos níveis de corrupção estatal por intermédio das constantes revelações de relações espúrias entre altos executivos com interesses em decisões governamentais (são emblemáticos nesse aspecto as realidades contemporâneas no Brasil, no Peru, na Bolívia e na Argentina com constantes denúncias de conúbio entre o capital privado e sua influência nas altas esferas da Administração Pública); assimetrias e carências na infraestrutura; as profundas desigualdades sociais e econômicas (muitas das cidades mais desiguais do mundo encontram-se na América do Sul); o poder paralelo do narcotráfico e a estrutura do crime organizado em âmbito transnacional (muitas vezes institucionalizado); violência urbana em níveis alarmantes, segundo dados coletados pela ONU (2018, online), das dez cidades mais 
violentas do mundo todas se encontram na América Latina (incluindo algumas capitais brasileiras). As constantes violações aos direitos humanos; as vicissitudes ambientais (poluição do ar e da água, desmatamento das florestas, utilização de técnicas agrícolas devastadoras à vida, dentre diversas outras) também limitam o êxito do projeto integracionista na América do Sul. A efetividade dos direitos fundamentais sociais também merece especial atenção ante a constatação de baixos níveis educacionais; acesso deficitário aos programas de saúde, dentre diversas outras questões que devem ser enfrentadas para a plenitude do processo integracionista.

O fortalecimento e a consolidação das ainda frágeis instituições nas democracias sulamericanas não devem passar por líderes personalistas carismáticos, caso contrário, estar-seiam reavivando o populismo e a autocracia. O caminho correto a ser seguido é outro: mediante a participação madura e ativa dos cidadãos, com instituições fortalecidas, legítimas, transparentes e eficazes; com a existência de um sistema de freios e contrapesos entre os poderes, com lideranças democráticas e uma sólida estrutura cívica (MARQUES JÚNIOR, 2016).

Sobre a necessidade de fortalecimento do valor democrático na América Latina para o futuro ante o passado problemático, vaticina o historiador mexicano Enrique Krauze (2018, online):

El siglo XIX latinoamericano fue el del caudillismo militarista. El siglo XX sufrió el redentorismo iluminado. Ambos siglos padecieron a los hombres 'necesarios'. Tal vez en el siglo XXI despunte un amanecer distinto, plenamente democrático, donde no haya hombres 'necesarios', donde los únicos necesarios seamos los ciudadanos actuando libremente en el marco de las leyes y las instituciones.

As iniciativas de fortalecimento do protagonismo popular, por meio da incorporação de mecanismos de democracia direta e autogestão no Novo Constitucionalismo Democrático Latino-Americano, são usurpadas pela predominância do Executivo como elemento recorrente na tradição política do País, caracterizada pelo hiperpresidencialismo e, em especial, nos casos equatoriano, boliviano e venezuelano pelo personalismo, nas figuras de Rafael Correa, Evo Morales e Hugo Chávez.

Outro sério entrave político imposto à efetividade do projeto integracionista sulamericano é a profunda crise política, econômica, social e humanitária envolvendo a Venezuela. 
Conforme noticia Alejandro Mendible (2013, p. 275), Hugo Chavez morreu em Caracas na terça - feira, dia 5 de março de 2013, e uma nova realidade política está emergindo na Venezuela, contando com um novo quadro, o MERCOSUL.

Desde a morte de Hugo Chávez ocorrida em 2013, a Venezuela vive inegável processo de crise econômica, política e social. O vazio de poder se acentuou com a pouca efetividade de seu sucessor, Nicolás Maduro e com a baixa do preço do petróleo no mercado internacional, uma vez que o País está bastante suscetível às baixas do preço do petróleo no mercado internacional por não ter conseguido se industrializar e criar uma infraestrutura dinâmica e independente.

Com o agravamento da crise econômica, o governo de Nicolás Maduro aumentou a repressão exercida contra seus opositores, as detenções arbitrárias, violações sistemáticas aos direitos humanos, a falta de eleições livres e o cerceamento das liberdades individuais, inclusive com a questionável eleição de uma nova Assembleia Nacional Constituinte.

Em dezembro de 2016, a Venezuela foi suspensa do MERCOSUL, sob o argumento jurídico que o país deixou de cumprir com os compromissos assumidos na sua adesão ao Bloco e, portanto, perdeu todos os direitos de participação.

Em agosto de 2017, com o agravamento da situação política e econômica na Venezuela, foi imposta nova suspensão pelo MERCOSUL à Venezuela, de índole política com base na ruptura democrática das regras esposadas pelo Protocolo de Ushuaia, que trata do compromisso democrático nos países do MERCOSUL, Bolívia e Chile.

Com as suspensões impostas à Venezuela pelo MERCOSUL, o direcionamento diplomático revela-se uma tentativa de demonstrar respaldo àqueles que tem lutado por forças democráticas dentro da Venezuela, especialmente a oposição.

O agravamento das crises social, política e econômica na Venezuela também reverberam no incremento dos fluxos migratórios de venezuelanos para os países fronteiriços, especialmente Brasil e Colômbia.

Para um futuro emancipatório e inclusivo para a Venezuela propõe-se mais diálogo, uma democracia aberta à participação cidadã e um governo atento, acessível e sensível aos clamores sociais.

Na perspectiva da integração almejada pela UNASUL, faz-se necessário um modelo definido de consolidação de uma epistemologia local, valorização da cultura autóctone, na qual se respeite toda a diversidade cultural sul-americana, de um espaço de troca de valores menos dependente das vontades governamentais, com um patamar inclusivo de cidadania e participação política democrática. Dá-se início, dessa forma, à etapa atual da conscientização 
no imaginário popular da integração da América do Sul, perfazendo uma genuína integração, cujo início é a criação da UNASUL.

Desta forma, coaduna-se com Darcy Ribeiro (2006, pág. 158) ao vaticinar que nosso destino é nos unificarmos com todos os latino-americanos por nossa oposição comum ao mesmo antagonista, que é a América anglo-saxônica, para fundarmos, tal como ocorre na comunidade europeia, a Nação Latino-Americana sonhada por Bolívar. Hoje, somos 500 milhões, amanhã seremos 1 bilhão. Vale dizer, um contingente humano com magnitude suficiente para encarnar a latinidade em face dos blocos chineses, eslavos, árabes e neobritânicos na humanidade futura. Somos povos novos ainda na luta para nos fazermos a nós mesmos como um gênero humano novo que nunca existiu antes. Tarefa muito difícil e penosa, mas também muito mais bela e desafiante.

\section{Considerações Finais}

A partir da análise do processo de integração sul-americano desde o período colonial até o século XX extraem-se alguns aportes para a atual conjuntura dos países regionais, o que demonstra o processo integracionista como inexorável.

O longo processo de integração sul-americana revela-se um caminho irreversível na busca de novos paradigmas democráticos e inclusivos, comprometidos com a implementação dos direitos humanos na construção do Estado Democrático de Direito, reavivado após as intensas manifestações populares ocorridas no Brasil em 2013 e na Venezuela em 2014.

A análise histórica demonstra que um processo de integração conduzido apenas por tecnocratas, sem a efetiva participação popular será fracassado, como demonstrado por várias experiências vividas na América do Sul. A legitimidade dos movimentos sociais exerce um papel fundamental para o êxito da consolidação do ideal integracionista.

Novos fundamentos axiológicos clamam por reconhecimento. Neste jaez, eis que surge o reconhecimento dos direitos humanos fundamentais à solidariedade, complementaridade, cooperação e paz como fundamentos indispensáveis à resolução de conflitos internos e externos dos movimentos sociais reivindicatórios de direitos humanos ocorridos nos países da América do Sul que devem agregar as reivindicações populares à pauta institucional do processo de integração.

O resgate dos direitos humanos fundamentais representará a redenção dos povos sul-americanos, cada vez mais envolvidos em discussões atreladas à legitimidade popular, 
promovidos pelo clamor do povo em resposta aos anseios de uma elite que busca de forma desenfreada a maximização e perpetuação de seus benefícios econômicos e políticos, em especial no tocante à exploração dos recursos naturais com potenciais energéticos (dentre os quais avulta em importância o petróleo, o gás natural, a água e os produtos alimentares).

Deve-se buscar um ritmo e modelo autóctone na integração dos países sul-americanos considerando-se que o modelo integrativo europeu, ocorrido após a Segunda Guerra Mundial, aconteceu numa velocidade acelerada haja vista a necessidade de recuperação da economia europeia, naquele momento em fase de dependência dos aportes financeiros norte-americanos (através do Plano Marshall). A influência exacerbada da agenda econômica econômico sobre o processo de integração europeu pode ser substituída por outros parâmetros no modelo sulamericano.

Faz-se mister que o espírito de união dos povos sul-americanos não se dissolva em divergências de facções político-ideológicas, para além da fórmula simplista dos modelos antagônicos direita/esquerda. Almeja-se a convergência de todos os seus atores em prol da efetiva inclusão dos cidadãos no gozo dos seus direitos humanos em um contexto democrático e inclusivo.

\section{Referências bibliográficas}

ARAÚJO, Leandro Rocha de. Associação Latino-Americana de Integração (ALADI). IN MERCADANTE, Araminta de Azevedo. CELLI JUNIOR, Umberto. ARAÚJO, Leonardo Rocha de (coordenadores). Blocos econômicos e integração na América Latina, África e Ásia. Curitiba: Juruá, 2008.

BONAVIDES, Paulo. Solução federalista para o problema da unidade latino-americana In: CADEMARTORI, Daniela Mesquita Leutchuck de; MORAES, Germana de Oliveira; CÉSAR, Raquel Coelho Lenz; CADEMARTORI, Sérgio Urquhart de. (Organizadores). A construção jurídica da UNASUL. 1 ed. Florianópolis: Editora da UFSC: Fundação Boiteux, 2011.

CARVALHO, José Murilo de. Cidadania no Brasil: o longo caminho. 12a - edição. Rio de Janeiro: Civilização Brasileira, 2009. 
CERVO, Amado Luiz, BUENO, Clodoaldo. História da política exterior do Brasil. $3^{\text {a }}$ edição. $2^{\mathrm{a}}$ - reimpressão. Brasília: Editora Universidade de Brasília, 2010.

DEL'OLMO, Florisbal de Souza. MORON, Eduardo Daniel Lazarte. Blocos Econômicos ou Áreas de Livre Comércio na América do Sul: Reflexões sobre a Aliança do Pacífico e o MERCOSUL. Disponível em:

$<\mathrm{http}: / /$ www.publicadireito.com.br/artigos/? cod=624c54021 cda44b5 $>$. Acesso em: 09 de maio de 2018.

DORATIOTO, Francisco. A Formação dos Estados Nacionais no Cone Sul. In: PATRIOTA, Antônio de Aguiar (organizador). A América do Sul e a integração regional. Brasília: FUNAG, 2012.

FAUSTO, Boris. História concisa do Brasil. 2a - edição. $3^{\text {a }}$ - reimpressão. São Paulo: Editora Universidade de São Paulo, 2010.

GUIMARÃES, Samuel Pinheiro. Desafios brasileiros na era dos gigantes. Rio de Janeiro: Contraponto, 2005.

GUIMARÃES, Samuel Pinheiro. Quinhentos anos de periferia: uma contribuição ao estudo da política internacional. 5'- edição. Rio de Janeiro: Contraponto, 2007.

HOLANDA, Sérgio Buarque de. Raízes do Brasil. 26ª - edição. São Paulo: Companhia das Letras, 1995.

KRAUZE, Enrique. El fin del redentorismo iluminado. Disponível em:

$<$ http://www.eltiempo.com/archivo/documento/CMS-12671436>. Acesso em: 10 de maio de 2018.

MARQUES JÚNIOR, William Paiva. A integração, o meio ambiente e a democracia na América do Sul: o significado do Novo Constitucionalismo Democrático LatinoAmericano e da democracia participativa para a construção da UNASUL. 403 f. Tese (Doutorado em Direito) - Programa de Pós-Graduação em Direito, Universidade Federal do Ceará (UFC), Fortaleza. 2016. 
MEIRELLES, Elizabeth. Comunidade Andina. IN MERCADANTE, Araminta de Azevedo. CELLI JUNIOR, Umberto. ARAÚJO, Leonardo Rocha de (coordenadores). Blocos econômicos e integração na América Latina, África e Ásia. Curitiba: Juruá, 2008. MENDIBLE Z., Alejandro. Venezuela: su tránsito elíptico en el destino histórico sudamericano y el rol moderador del Brasil en el presente. In: CARMO, Corival Alves do (et. al.) Relações internacionais: olhares cruzados. Brasília: FUNAG, 2013.

MOREIRA, Luiz Felipe Viel; QUINTEROS, Marcela Cristina; SILVA, André Luiz Reis da.. As relações internacionais da América Latina. Petrópolis, RJ: Vozes, 2010.

ORGANIZAÇÃO DAS NAÇÕES UNIDAS (ONU). Disponível em: < http://www.unodc.org/lpo-brazil/pt/frontpage/2014/04/10-some-437000-people-murderedworldwide-in-2012-according-to-new-unodc-study.html>. Acesso em: 09 de maio de 2018.

RIBEIRO, Darcy. O povo brasileiro: a formação e o sentido do Brasil. São Paulo: Companhia das Letras, 2.006.

SIMÕES, Antonio José Ferreira. Integração: sonho e realidade na América do Sul. Brasília: FUNAG, 2011.

SORJ, Bernardo; MARTUCCELLI, Danilo. O desafio latino-americano: coesão social e democracia. Tradução: Renata Telles. Rio de Janeiro: Civilização Brasileira, 2008.

VIEIRA, Luciane Klein. Interpretación y aplicación uniforme del Derecho de la Integración. Unión Europea, Comunidad Andina y Mercosur. Montevideo: Editorial B de F, 2011. 


\section{DIREITO INTERNACIONAL DOS DIREITOS HUMANOS ${ }^{1}$}

\section{APRESENTAÇÃO}

Frutos de estudos aprovados para o VIII ENCONTRO INTERNACIONAL DO CONPEDI Conselho Nacional de Pesquisa e Pós-Graduação em Direito, realizado em Zaragoza, Espanha, entre os dias 06 a 08 de setembro de 2018, cujo tema foi Direito, Argumentação e Comunicação: Desafios para o século XXI, apresentamos à comunidade jurídica a presente obra voltada ao debate de temas contemporâneos de Direito Internacional dos Direitos Humanos.

Na coordenação das apresentações do GT " Direito Internacional dos Direitos Humanos I ", pudemos testemunhar relevante espaço voltado à disseminação do conhecimento produzido por pesquisadores das mais diversas regiões do Brasil e da Espanha, vinculados aos Programas de Mestrado e de Doutoramento em Direito. Os estudos, que compõem este livro, reafirmam a necessidade do compartilhamento das pesquisas direcionadas aos direitos humanos, como, também, se traduzem em consolidação dos esforços para o aprimoramento da área e da própria Justiça no âmbito internacional.

O campo de investigação "Direito Internacional dos Direitos Humanos" tem presenciado transformações desde o Pós Segunda Guerra, quando da criação da Organização das Nações Unidas (ONU), em 1945. A Carta de São Francisco (1945), que constitui a ONU, elege a cooperação internacional na promoção dos direitos humanos como um tema central da sua agenda de atuação. Documentos e instrumentos internacionais de direitos humanos são afirmados, tendo a Declaração Universal dos Direitos Humanos (1948) como um documento paradigmático nesse processo na perspectiva da universalidade, interdependência e indivisibilidade dos direitos humanos. A chamada Guerra Fria, caracterizada pela bipolaridade entre os Estados Unidos da América e a então União Soviética, vai marcar a elaboração dos pactos internacionais de direitos humanos de 1966. Ao invés de um, são afirmados dois pactos, um voltado para o reconhecimento dos direitos civis e políticos, e outro voltado ao reconhecimento dos direitos econômicos, sociais e culturais. Instrumentos vinculantes que são, os pactos de 1966 obrigam os Estados-parte a protegerem e a promoverem, no âmbito doméstico, sob pena de responsabilidade internacional, os direitos humanos resguardados

\footnotetext{
${ }^{1}$ Nota Técnica: Os artigos que não constam neste livro foram selecionados para publicação na Plataforma Index Law Journals, - http://indexlaw.org/index.php/conpedireview/index.
} 
nesses instrumentos. Ao lado desse movimento internacional de reconhecimento, a ponto de Lindgren Alves (2007) afirmar que os direitos humanos se constituem como um tema global, em livro com mesmo título, são reconhecidas demandas específicas voltadas à proteção de grupos vulneráveis, como crianças, pessoas com deficiência, mulheres, indígenas e, também, matérias consideradas centrais no âmbito internacional e doméstico, tais como os temas da discriminação racial, discriminação contra a mulher, discriminação no ensino, inclusão social e educativa, entre outros, encabeçadas pelas agências da ONU, como a Organização Internacional do Trabalho (OIT) e a Organização das Nações Unidas para a Educação, a Ciência e a Cultura (UNESCO). Outro marco histórico fundamental, que vai influenciar o processo de afirmação dos direitos humanos no âmbito internacional, consiste na queda do Muro de Berlim (1989) e na dissolução da URSS (1991), simbolizando o fim da Guerra Fria. A Declaração e o Programa de Ação de Viena (1993) são elaborados nesse contexto simbólico. Documentos que elegem o ensino dos direitos humanos como um tema central da agenda ONU, esboçado preliminarmente no preâmbulo e no art. 26 da Declaração Universal dos Direitos Humanos de 1948. O contexto agora é diferente. Não obstante o avanço na afirmação dos direitos humanos, nos deparamos com problemáticas de investigação e de reflexão social ocasionadas pela crise de 2008 do sistema capitalista. Problemáticas e reflexões que impactam nos temas a tratar, nas agendas a construir, nos problemas selecionados e na abordagem a ser utilizada na análise dos desafios da pesquisa em direito internacional dos direitos humanos.

Nesse sentido, apraz-nos abrir as portas do conhecimento indicando os artigos apresentados e amplamente debatidos, os quais se encontram abaixo sintetizados. $\mathrm{O}$ artigo, de autoria das professoras Valéria Silva Galdino Cardin e Tereza Rodrigues Vieira, versa sobre os recentes fluxos migratórios no Brasil, problematizando questões de discriminação e de invisibilidade social, sobretudo de grupos sociais oriundos da Venezuela, realçando a ênfase econômica estimuladora desses fluxos migratórios recentes. O artigo, intitulado Os Limites de Realização dos Direitos Humanos e seu Condicionamento à Soberania do Estado-Nação. Reflexões sobre os Refugiados na Teoria de Hannah Arendt, de autoria de Ridivan Clairefont de Souza Mello Neto e Loiane da Ponte Souza Prado Verbicaro, inova metodologicamente ao problematizar a questão dos refugiados, a partir da abordagem de Arendt, sobretudo no livro As Origens do Totalitarismo. Conclui com a reflexão de que as premissas do pensamento iluminista estão em crise, colocando desafios ao pensar e à fundamentação crítica dos direitos humanos dos refugiados neste início de século XXI. O artigo Tribunal Híbrido do Camboja: Instrumento Judicial para a Proteção dos Direitos Humanos, de autoria de Renata Mantovani de Lima, 
problematiza a constituição de tribunais dessa natureza para a proteção dos direitos humanos como um mecanismo de resolução de conflitos. Ao adotar uma perspectiva crítica, a autora analisa a formação ad hoc desses tribunais, questionando a forma de resolução de conflitos dos casos sub judice. A professora Iranice Gonçalves Muniz, autora do artigo Cooperação Jurídica Internacional: Tortura como Crime contra a Humanidade e a Justiça de Transição no Brasil, traz uma reflexão sobre a tipificação da tortura no rol dos crimes contra a humanidade sob a jurisdição do Tribunal Penal Internacional, problematizando, a partir dos casos empíricos levados à Comissão da Verdade, no Brasil, de mulheres torturadas, a necessidade de constituição de uma prática educativa fundamentada no Educar para o Nunca Mais. Prática esta voltada a uma socialização cultural contra regimes ditatoriais e suas consequências. $\mathrm{O}$ artigo, de autoria de Sergio Daniel Ruiz Díaz Arce, com o título O Exercício Progressivo dos Direitos da Criança: as Premissas da Corte Interamericana de Direitos Humanos sob a Perspectiva dos Acordos Argumentativos Propostos por Perelman e Olbrechts-Tyteca, problematiza questão central no debate contemporâneo relativo à proteção internacional dos direitos humanos. A partir das perspectivas da situação irregular e da proteção integral, o autor analisa os argumentos e a jurisprudência da Corte IDH, utilizando-se da abordagem do auditório universal e do auditório particular problematizada por Perelman. O estudo é fundamentado teórica e empiricamente, trazendo uma relevante contribuição ao campo da pesquisa jurídica. $\mathrm{O}$ artigo intitulado Estado Democrático de Direito e a Humanização e Acolhimento à Pessoa Idosa como Respeito à Dignidade Humana e à Cidadania: Considerações de Caráter Normativo e Culturais, de autoria de Cláudia Mansani Queda de Toledo e Flavia Piva Almeida Leite, traz uma reflexão sobre um grupo vulnerável, sujeito-objeto de investigação no campo de pesquisa sobre direitos humanos, a pessoa idosa. Ao pensar o idoso como um sujeito de direito, os autores analisam a matéria a partir dos fundamentos constitucionais e da tutela específica concernente ao envelhecimento, sobretudo do Estatuto do Idoso. Concluem pela necessidade de elaboração de políticas públicas voltadas à proteção desse grupo vulnerável. $\mathrm{O}$ artigo seguinte, de autoria de Adriana Fasolo Pilati Scheleder e Janaina de Oliveira, intitulado Pessoas com Deficiência: da Segregação à Proteção Internacional, realiza uma incursão histórica sobre as mudanças de tratamento normativo e social relativas à pessoa com deficiência, do modelo médico ao modelo social, problematizando questões concernentes ao Estatuto da Pessoa com Deficiência e à necessidade de remoção de barreiras e de promoção da acessibilidade. Encerrando o presente livro, o professor Sébastien Kiwonghi Bizawu, no artigo Direitos Humanos e Conflitos Armados: as Contradições e Perspectivas da Comunidade Internacional, problematiza a questão da articulação do Direito Internacional Humanitário e dos Direitos Humanos no reforço da 
proteção internacional em contexto de conflitos armados. Chama à atenção sobre o pano de fundo econômico que estimula a ocorrência desses conflitos, muitos dos quais promovidos e incitados por empresas transnacionais e pelas grandes potências econômicas em países do Sul Global, ricos em recursos naturais, sobretudo em minérios que constituem matéria-prima da fabricação de chips para telemóveis. Conclui que o poder econômico se sobrepõe em realidades sociopolíticas marcadas pela perda da autoridade do Estado, levando a contradições no processo de efetivação dos direitos humanos.

Os estudos aqui reunidos indicam a necessidade de pesquisas sobre a matéria, mas, também, a urgente consolidação da democracia e do Estado de Direito, especialmente em realidades socioculturais marcadas por violações de direitos nas mais diversas áreas. No campo de investigação, novas temáticas são alçadas a questões centrais na agenda de debate contemporâneo, indicando a necessária historicidade do processo de afirmação e reconhecimento dos direitos humanos.

Zaragoza/Espanha, 07 de setembro de 2018.

Coordenadores do GT:

Profa. Dra. Flávia Piva Almeida Leite (UNESP)

Profa. Dra. Maria Creusa de Araújo Borges (PPGCJ, UFPB) 


\title{
COOPERAÇÃO JURÍDICA INTERNACIONAL: TORTURA COMO CRIME CONTRA A HUMANIDADE E A JUSTIÇA DE TRANSIÇÃO NO BRASIL
}

\author{
Iranice Gonçalves Muniz \\ Universidade Federal da Paraíba e \\ Centro Universitário de João Pessoa
}

\begin{abstract}
Resumo
A presente pesquisa foi realizada durante a elaboração do relatório final da Comissão Estadual da Verdade e da preservação da memória no estado da Paraíba, Brasil. Teve por objetivos analisar as mudanças ocorridas no âmbito internacional e nacional com a criação do Tribunal Penal Internacional, com o advento do Estatuto de Roma; e detectar em que proporções estas mudanças têm contribuído para redefinir a relação entre os Estados, no interior da Organização das Nações Unidas e Organização dos Estados Americanos no que se refere a tortura como crime contra a humanidade; como também analisar a legislação brasileira que impede a punição dos agentes públicos que violaram direitos humanos no período da Ditadura Militar.
\end{abstract}

Palavras-chave: Tortura, Crime contra a humanidade, Dignidade da pessoa humana, Justiça de transição.

\begin{abstract}
Resumen/Résumé
This research was carried out during the elaboration of the final report of the State Commission of Truth and the preservation of memory in the state of Paraíba, Brazil. Its objectives were to analyze the changes that had taken place at international and national levels with the creation of the International Criminal Court, with the advent of the Rome Statute; and to detect the extent to which these changes have contributed to redefining the relationship between countries within the United Nations and the Organization of American States in relation to torture as a crime against humanity; as well as to analyze the Brazilian legislation that prevents the punishment of public agents who violated human rights in the period of the Military Dictatorship.
\end{abstract}

Keywords/Palabras-claves/Mots-clés: Torture, Crime against humanity, Dignity of human person, Transitional Justice 


\section{Introdução}

A discussão da temática "tortura como crime contra a humanidade" é deveras importante diante da cultura herdada dos períodos de regime ditatorial (Estado de exceção) vivenciados por vários países, especialmente no Estado brasileiro.

Decerto que a presença de práticas de torturas não é um fenômeno militar novo, contudo, é importante salientar que consta dos tratados internacionais a proibição e a tipificação como crime contra a humanidade.

A tortura em prol das ideologias e de interesses diversos é um dos mais graves problemas com que a Organização das Nações Unidas (ONU) tem se confrontado desde a segunda metade do século XX, principalmente através do Estatuto de Roma.

Para o presente trabalho, o olhar, também histórico deve contribuir para uma melhor compreensão global dessa questão. Entretanto, não se trata simplesmente de estudar o direito atual historicamente, mas, doutra forma, identificar um período na história e verificar nele as questões jurídico-ideológicas que foram cruciais no processo de formulação do direito internacional dos direitos humanos.

A Segunda Guerra Mundial e os regimes ditatoriais que se instalam em vários Estados são acontecimentos marcantes do século passado além de representar um marco divisório na história dos direitos humanos em escala regional e mundial.

É com o fim do estado de beligerância que se inicia o processo de Nuremberg, no qual foram julgados alguns dos representantes da Alemanha nazista, e onde se mudam paradigmas e se inicia uma nova era para os direitos humanos.

Após a Segunda Guerra Mundial surgiram a Organização das Nações Unidas (ONU), em 1945, a Declaração Universal dos Direitos Humanos (DUDH), em 1948 e inicia-se o processo de criação de um Tribunal Penal Internacional (TPI) para julgamento dos crimes praticados contra a humanidade. Isso, por si só, já justificaria a importância do tema. Parte-se da hipótese de que, o crime de tortura ainda hoje é vivenciado por uma parcela significativa da humanidade.

O objetivo geral é analisar as mudanças ocorridas no âmbito internacional e nacional com a criação do Tribunal Penal Internacional, com o advento do Estatuto de Roma. Os objetivos específicos busca detectar em que proporções estas mudanças têm contribuído para redefinir a relação entre os Estados, no interior da Organização das Nações Unidas e Organização dos Estados Americanos no que se refere a tortura como crime contra a 
humanidade; como também analisar a legislação brasileira que impede a punição dos agentes públicos que violaram direitos humanos no período da Ditadura Militar.

Metodologicamente, para melhor desenvolver essa temática optou-se por dividir o texto da seguinte forma: (i) Instância Jurisdicional Internacional em Matéria Penal (ii) Internacionalização dos Direitos Humanos; (iii) Combate à Tortura no Direito Internacional; e (iv) Anistia brasileira, a Justiça de Transição e a Tortura.

\section{Instância Jurisdicional Internacional Em Matéria Penal}

A ideia de criação de uma instância internacional em matéria penal começa a ser desenhada no final do século XIX quando, no ano de 1872, Gustave Moynier, então presidente do Comitê Internacional da Cruz Vermelha, apresentou, naquele Comitê, uma proposta de criação, mediante tratado, de um tribunal internacional, em resposta aos crimes cometidos na Guerra Franco-Prussiana ${ }^{1}$.

Somente no século XX, a criação de uma instância internacional em matéria penal tornou-se não só um ideal, mas uma necessidade imprescindível que começou a ser construída com término da Primeira Guerra Mundial (1914-1918). Em 1919, o Tratado de Versalhes determinava que o Kaiser Guilherme II e outros alemães tinham violado as leis de guerra e, portanto, deveria ser submetido a um tribunal internacional ( $a d$ hoc) para julgá-los ${ }^{2}$.

Em 1924 houve, em Paris, o surgimento da Associação Internacional de Direito Penal. Mas a ideia de um Tribunal Penal internacional só ganhou força efetiva, no fim da Segunda Guerra, com a criação da Organização das Nações Unidas (ONU), em 1945.

Até a Segunda Guerra Mundial (1939-1945) as normas internacionais eram dirigidas exclusivamente aos Estados. A ideia vigente naquele momento histórico ainda levava em consideração as disposições normativas dos Tratados de Westphalia, elaborados no ano de $1648^{3}$ que, segundo Gonçalves (2004, p.5), garantiam a defesa da soberania estatal absoluta e a total impossibilidade de qualquer intervenção.

\footnotetext{
${ }^{1}$ Embora, a referência histórica de uma corte internacional encontra seu registro no caso do julgamento de Landvogt Peter von Hagenbach, governador do Município de Breisach, em 1474, na Alemanha, pelo cometimento de diversos crimes. Ele foi julgado num tribunal formado por magistrados, da Áustria e cidades aliadas, que tinham ligação com o Império Romano Germânico. Ver FERNANDES, David Augusto. Tribunal penal internacional: a concretização de um sonho. Rio de Janeiro: Renovar, 2006, p. 126.

${ }^{2}$ Guilherme II refugiou-se na Holanda, que se negou a extraditá-lo sob a argumentação de que se tratava de delito político. O tribunal de exceção não foi criado e o julgamento dos demais alemães coube à Suprema Corte Alemã.

${ }^{3}$ Tratado de Múnster e Tratado de Osnabrück, que encerraram a Guerra dos Trinta Anos.
} 
Com o fim da Segunda Guerra Mundial, em 1945, surgiu o primeiro tribunal internacional criminal (ad hoc) do século XX: o Tribunal de Nuremberg, foi instalado em 8 de novembro de 1945, pelo Acordo de Londres, como Tribunal Militar Internacional ${ }^{4}$, para julgar os crimes cometidos durante o período de beligerância. No entanto, esse Tribunal era composto pelos Estados Unidos da América, pela União das Repúblicas Socialistas Soviéticas (URSS), pelo Reino Unido da Grã-Bretanha e pela França - os chamados países “aliados” - que, segundo Mello (2004, p. 974) se contrapunham aos países do "eixo europeu."

O Tribunal de Nuremberg foi alvo de várias críticas internacionais, pois todos os magistrados, bem como seus suplentes, foram indicados pelos Estados "aliados", ou seja, não havia nenhum juiz de outras nacionalidades. Obviamente, só foram levados a julgamento alguns dos criminosos do "eixo europeu", conforme estabelecia o artigo $1^{\circ}$ do Estatuto do Tribunal Militar Internacional de Nuremberg ${ }^{5}$. Com as mesmas características foi criado o Tribunal Militar Internacional de Tóquio - para o julgamento de violações de direitos humanos cometidas pelas autoridades japonesas durante a Segunda Guerra Mundial.

Embora tenham sido alvo de muitas críticas, não se pode negar a relevância histórica pois, não obstante tenham sido tribunais de exceções, os Tribunais de Nuremberg e Tóquio foram os primeiros na história da humanidade com as efetivas propriedades internacionais penais.

A criação de um Tribunal Penal Internacional Permanente, para substituir os tribunais de exceções, partiu do então presidente dos Estados Unidos, Harry S. Truman. Essa ideia foi cogitada em 1948, quando a Assembleia Geral das Nações Unidas pediu à Comissão de Direito Internacional que examinasse a possibilidade de ser criado um tribunal para julgar casos semelhantes aos que haviam sido submetidos aos Tribunais de Nuremberg e de Tóquio. Todavia, devido o agravamento da guerra fria não foi possível que tal iniciativa tivesse prosseguimento ${ }^{6}$.

Se, juridicamente, os tribunais de exceção desrespeitavam expressamente o princípio da anterioridade da lei, o princípio do juiz natural dentre outros, deveria haver um

\footnotetext{
${ }^{4}$ É de salutar importância observar que a palavra 'Militar' na denominação do Tribunal está equivocada, vez que o único militar que o compunha era o juiz soviético.

${ }^{5} \mathrm{O}$ artigo $1^{\circ}$, Estatuto do Tribunal Militar Internacional de Nuremberg estabelecia que: "Em execução do Acordo assinado em 08 de agosto de 1945 pelo Governo Provisório da República Francesa e os governos dos Estados Unidos da América, do Reino Unido da Grã-Bretanha e Irlanda do Norte e da União das Repúblicas Socialistas Soviéticas, será criado um Tribunal Militar Internacional [...] para julgar e punir de modo apropriado, e sem tardança, os grandes criminosos de guerra dos países europeus do Eixo.

${ }^{6}$ É o caso do Tribunal Penal Internacional para a Antiga Iugoslávia, mediante a Resolução $n^{\circ} 808$, de 22 de fevereiro de 1993; e também o Tribunal Penal Internacional para Ruanda, por meio da Resolução ${ }^{\circ} 955$ de 8 de novembro de 1994.
} 
comprometimento dos sujeitos de Direito Internacional Público na apuração de condutas ilícitas que viessem a atingir a esfera penal, concedendo uma garantia de coerção aos responsáveis pelas violações de direitos humanos, principalmente nos crimes de genocídio, lesa humanidade, de guerra e quaisquer outros que configurem desobediência à Convenção de Genebra de 1949 e seus Protocolos Adicionais de 1977.

Assim, mediante resolução do Conselho de Segurança da Organização das Nações Unidas (ONU), o Tribunal Penal Internacional (TPI) foi criado por meio de um tratado internacional denominado Estatuto de Roma.

O Estatuto de Roma foi aprovado, em 1998, por 120 Estados e teve sete votos contrários: Estados Unidos, China, Índia, Israel, Filipinas, Sri Lanka e Turquia ${ }^{7}$, além de 21 abstenções. Entrou em vigor, no âmbito internacional, em 01 de julho de 2002, correspondente ao primeiro dia do mês seguinte ao termino do período de sessenta dias após a data do depósito do sexagésimo instrumento de ratificação, de aceitação, de aprovação ou de adesão junto ao Secretário-Geral das Nações Unidas, nos termos do seu artigo 126, § $1^{\circ}$ de tal Estatuto.

De acordo com o Estatuto de Roma, o Tribunal Penal Internacional é composto por 18 juízes, de nacionalidades diferentes, do sexo masculino e feminino, com mandato de nove anos. Esse número pode ser elevado em razão do volume de trabalho, por proposta da Presidência, devendo ser objeto de apreciação em sessão da Assembleia dos Estados-Partes, com aprovação de dois terços dos membros.

Esse Tribunal prima pelo respeito ao princípio do juiz natural, ao princípio da reserva legal, ao princípio da legalidade e ao princípio da anterioridade, pois seus os juízes já foram escolhidos para a sua composição, e a norma jurídica a ser aplicada aos atos tipificados como crimes internacionais já foi consubstanciada no Estatuto de Roma.

Em respeito ao princípio das dignidade da pessoa humana, o Estatuto de Roma estabelece que o Tribunal Penal Internacional não terá jurisdição sobre as pessoas menores de dezoito anos à época da prática da conduta criminosa. Observado o mesmo princípio, é inaplicável a pena de morte, e a pena privativa de liberdade não poderá ser superior a trinta anos, salvo em casos de extrema gravidade, quando será possível o estabelecimento de prisão

\footnotetext{
7 Os EUA argumentaram que o Tribunal Penal Internacional poderia debilitar o Conselho de Segurança da Organização das Nações Unidas e que a Corte não deveria ter competência sobre cidadãos de países que não tivessem ratificado o Estatuto de Roma. A China votou de forma contrária à criação em virtude da questão do Tibet. A Índia entendeu que o Tribunal ofende sua soberania. Israel votou contrário a criação em face do conceito, adotado no Estatuto de Roma, de crimes de guerra.
} 
perpétua. Mas, nesse caso, haverá obrigatoriamente uma revisão da pena decorridos 25 anos do seu cumprimento.

O Estatuto de Roma visa a responsabilidade de indivíduos e não de Estados ou Organizações Internacionais. Portanto, se num Estado ou numa Organização Internacional se comete um ato delituoso que configure genocídio, crime contra a humanidade ou crime de guerra devem ser buscados os responsáveis físicos, que vão responder pessoalmente perante o Tribunal Penal Internacional. Segundo Mazzuoli (2005) isso ocorre porque sem a responsabilidade criminal individual não se alcança a finalidade do Direito Penal tanto no âmbito interno como no âmbito internacional.

O Estatuto de Roma é o instrumento legal que rege a competência e o funcionamento do Tribunal Penal Internacional (artigo $1^{\circ}$ ) e define quais são os crimes que constituem uma ameaça à paz, à segurança e ao bem-estar da humanidade.

Ademais, a atuação do Tribuna Penal Internacional é regida pelos princípios da complementaridade, da universalidade, da responsabilidade penal individual, do juiz natural, da legalidade e da imprescritibilidade.

O princípios da complementaridade está previsto no art. $1^{\circ}$ do Estatuto de Roma e estabelece que o referido tribunal será uma instituição permanente, com jurisdição sobre aqueles que cometerem crimes de maior gravidade e abrangência internacional (fixados nos termos do Estatuto) e agirá de forma complementar às jurisdições penais nacionais .

O princípio da universalidade determina que os Estados-membro se submetam a jurisdição da Corte Penal Internacional, não podendo se eximir de sua apreciação em determinados casos ou situações. Assim, cada Estado signatário deve aceitar integralmente o que dispõe o Estatuto de Roma.

O princípio da responsabilização penal preconiza que dos crimes sob a jurisdição do Tribunal Penal Internacional repousa sobre o indivíduo, sem prejuízo da responsabilidade do Estado perante a ordem internacional. (Art. $25 \S 4^{\circ}$, do Estatuto de Roma).

O princípio do juiz natural se contrapõe aos tribunais de exceções pois assegura que o juiz deve ser pré-constituído pela lei e não constituído post factum, e assegura ainda a impossibilidade de alteração discricionária das competências judiciais, garantindo a unidade de jurisdição.

O princípio da legalidade está previsto no Estatuto de Roma, em seus art. 22, 23 e 24, quando dispõe em seu capítulo III os princípios gerais do Direito Penal: nullun crimen sine lege, nulla poena sine lege e irretroatividade ratione personae. 
O princípio da imprescritibilidade está presente no Estatuto de Roma em seu art. 29, que determina: "Os crimes da competência do Tribunal não prescrevem". Essa imprescritibilidade está relacionada com a manutenção da ordem jurídica internacional.

A utilização da tortura em período ditatorial é um fato comum no decorrer da História e um dos grandes problemas na pauta da Organização das Nações Unidas e da Organização dos Estados Americanos. Dentre os crimes tipificados no Estatuto de Roma está incluso os crimes contra a humanidade, em respeito a vida e a dignidade da pessoa humana.

\section{Internacionalização dos Direitos Humanos}

O fim da Segunda Guerra Mundial e o consequente julgamento nos tribunais de exceções de Nuremberg e Tóquio significou para a sociedade internacional uma mudança nos paradigmas do Estado de Direito ${ }^{8}$. Segundo Sikkink (2011, p. 34), a partir de então duas perspectivas foram repensadas: na ordem interna de cada Estados, as Constituições passaram a ser rígidas e obrigatória para todos os poderes públicos, como parâmetro de controle na edição e aplicação das normas infraconstitucionais; na ordem internacional deu-se início a uma era da responsabilização, voltada para a responsabilização internacional de agentes públicos, independentemente do cargo ou da função que exerça, inclusive os chefes de Estado, por violações de direitos humanos.

Essa nova "Era da Responsabilização Penal" consistiu em duas mudanças significativas no panorama político global: uma nos Estados, que passaram a punir internamente os agentes acusados de crimes e violações de direitos humanos; e outra em âmbito internacional, a partir dos instrumentos internacionais que passaram a compor a base jurídica internacional para os processos e julgamentos nos tribunais internacionais ${ }^{9}$.

Nesse sentido, as instituições existentes, como a Corte Interamericana de Direitos Humanos, começaram a interpretar as obrigações do Estado sob a atual legislação dos direitos humanos, incluindo a responsabilidade de investigar e punir os criminosos.

\footnotetext{
${ }^{8}$ Outros tribunais internacionais $\mathrm{Ad}$-Hoc foram criados como é o caso do Tribunal Ad-Hoc para a Antiga Iugoslávia (ICTY, na sigla em inglês) e do Tribunal Ad-Hoc para Ruanda (TPIR), que avançaram na doutrina e na jurisprudência internacional sobre a responsabilização penal individual.

9 As violações de direitos humanos praticadas durante a Segunda Guerra Mundial obrigaram a sociedade internacional a passar do modelo reinante de impunidade, onde não havia punição pelas violações de direitos humanos praticadas por agentes dos Estados, para o modelo de responsabilização dos Estados, em que estes passaram a ser responsabilizados internacionalmente pelas violações de direitos humanos praticadas dentro de seus territórios.
} 
Esse fenômeno, chamado terceira onda evolutiva do Direito ${ }^{10}$, para Gomes e Mazzuoli (2011, p. 58) revela o compromisso do Estado, assumido perante a sociedade internacional, de impedir que sejam cometidas internamente novas violações contra os direitos e garantias fundamentais.

Sem dúvida, a mais importante das etapas do processo de internacionalização dos direitos humanos consiste na sua experiência prática, na aplicação das medidas acordadas internacionalmente, na efetividade, enfim, que lhe deve ser dada pelos poderes constituídos locais. A bem da verdade, de nada adiantariam os trâmites formais de incorporação de uma norma internacional sobre direitos humanos, se ela não contasse com efetivas ações governamentais no sentido de sua implementação.

Os compromissos assumidos internacionalmente restariam violados se o Estado-parte não envidasse esforços no sentido de dar concretude à proteção de direitos humanos, na exata forma com que formalmente anuiu, mantendo-se omisso.

Entre o Direito Internacional dos Direitos Humanos e o direito interno deve haver, na verdade, uma relação dialógica, de complementaridade, Nesta articulação de fontes normativas, que caracteriza o Estado contemporâneo, em que não há a prevalência de uma única legislação em detrimento de outras, haverá de ser aplicada no caso concreto a norma mais favorável à pessoa humana e sua dignidade.

Neste contexto, portanto, o papel a ser desempenhado pelos poderes públicos, em particular, o Poder Judiciário é o de justamente aplicar ao caso concreto a norma mais eficaz no que tange à proteção do sujeito titular de direitos humanos fundamentais, como forma de cooperação jurídica internacional em matéria de direito internacional dos direitos humanos.

\section{Combate à Tortura no Direito Internacional}

No cenário internacional, a primeira referência aos crimes contra a humanidade fora de um contexto de guerra foi a Convenção das Nações Unidas para Prevenção e Punição do Genocídio, de 1948. Posteriormente, a Convenção das Nações unidas sobre a Imprescritibilidade dos Crimes de Guerra e dos Crimes contra a Humanidade, de 1968, determinou que estes crimes são imprescritíveis, quando praticados em tempos de guerra ou em tempos de paz.

\footnotetext{
10 A primeira e a segunda ondas evolutivas do Estado, Direito e Justiça são, respectivamente, o legalismo e o constitucionalismo. Juntamente com a terceira, denotam a mesma preocupação de prevenção e reparação às violências cometidas contra os direitos humanos.
} 
A tortura é um dos crimes ofensivos aos direitos humanos e destaca-se por ser de difícil persecução criminal. Apesar de ainda ser uma prática corriqueira no mundo, praticada por autoridades estatais e agentes públicos, muitas vezes de forma aberta, em ambiente público ou privado, a tortura não é tratada por alguns Estados como o crime grave que é e isto se reflete nas poucas condenações criminais que há sobre acusações de tortura, principalmente no âmbito das jurisdições internas dos Estados-membro da ONU.

A proibição da tortura consta em vários tratados internacionais, de caráter universais e regionais, embora não precisasse constar destes expressamente para ser considerada uma norma de cumprimento obrigatório pelos Estados, haja vista que na doutrina internacional, segundo Mazzuoli (2010, p. 75), esta proibição é uma norma imperativa de direito, ou uma norma de jus cogens. A todo o tempo, em estado de guerra, ou de paz, os Estados devem buscar prevenir, punir e abolir a tortura, em razão do compromisso formal que tem com os direitos humanos.

Isto porque a prática da tortura atenta contra a dignidade da pessoa humana. Princípio fundamental das sociedades pós Segunda Guerra Mundial, assim descrita na maioria das constituições ocidentais, incluindo a Constituição brasileira de $1988 \mathrm{em} \mathrm{seu}$ artigo $1^{\text {o }}$, inciso III.

O objeto jurídico protegido pela norma imperativa de proibição da tortura frente a uma autoridade estatal é o princípio do respeito à dignidade da pessoa humana, para garantir um direito fundamental que é o direito à integridade pessoal, tanto física, quanto psicológica.

Para Dourado (2001, p. 179), na tortura, atenta-se contra a dignidade da pessoa humana na medida em que se nega ao torturado a sua condição de pessoa, transformando-a num mero objeto. Há na prática da tortura a degradação da vítima de sua condição humana, privandoa de sua liberdade, tornando-a objeto do torturador, deixando-a à sua mercê, comportando-se como esse deseja e ordena.

O Estatuto de Roma, no artigo $7^{\circ}$, reconhece a tortura e o desaparecimento forçado como crimes contra a humanidade com a seguinte redação: "Para os efeitos do presente Estatuto, entende-se por "crime contra a humanidade, qualquer um dos atos seguintes, quando cometido no quadro de um ataque, generalizado ou sistemático, contra qualquer população civil, havendo conhecimento desse ataque: [...] f) tortura [...] i) desaparecimento forçado".

A tortura está no rol dos crimes contra a humanidade exatamente porque, quando esta é praticada, não só sua vítima direta é atingida e violada. A tortura, assim como os demais crimes contra a humanidade, atinge todos os seres humanos. É, portanto, um crime de lesa humanidade. Esta noção parte da ideia de que os direitos humanos são princípios superiores ao 
direito interno dos Estados e que devem ser protegidos e efetivados pelo Direito Internacional dos Direitos Humanos e pelo Direito Internacional Penal.

Por ser um crime de lesa humanidade, a tortura apresenta as seguintes características: é imprescritível; aos responsáveis pela sua prática não se pode conceder refúgio ou asilo; e os seus corresponsáveis não podem alegar a obediência hierárquica para fins de justificativa da conduta delituosa. Ademais, a proibição da tortura é norma não derrogável pelos Estados em suas normas internas, o que implica no fato de que não é possível aos Estados restringir essa proibição em nenhuma circunstância, tanto por esta ser norma imperativa de jus cogens, quanto pela proibição da restrição estar expressa nos tratados internacionais que versam sobre o tema.

A Declaração Universal de Direitos Humanos, aprovada pela Assembleia da Organização das Nações Unidas (ONU) em 1948, proíbe, dentre outras práticas, a da tortura e tratamentos cruéis, desumanos ou degradantes. O Pacto Internacional sobre os Direitos Civis e Políticos de 1966, em seu artigo $7^{\circ}$, também prevê a proibição da tortura.

Em 1984 foi aprovada a Convenção contra a Tortura e outros Tratamentos ou Penas Cruéis, Desumanos ou Degradantes, pela Assembleia da ONU. Partindo para prática da responsabilização penal individual, a Convenção de 1984 criou o tipo penal da tortura institucional que ocorrerá:

[...] quando as dores ou sofrimento forem infligidos por funcionário público ou outras pessoa no exercício de funções públicas, ou por sua instigação, ou com seu consentimento ou aquiescência." (Art. $1^{\circ}$ da Convenção). Ademais, segundo a Convenção "Em nenhum caso poderão invocar-se circunstâncias excepcionais, como ameaça ou estado de guerra, instabilidade política interna ou qualquer outra emergência pública, como justificação para a tortura. $\left(\right.$ Art. $\left.2^{\circ}\right){ }^{11}$

Ao lado da possibilidade da responsabilização singular do agente público que praticou tortura, os Estados Partes da Convenção de 1984 aceitaram se submeter a jurisdição universal para processo e julgamentos destes crimes, o que significa que qualquer destes Estados pode denunciar outro agente ou outro Estado pela prática de tortura junto a Corte Internacional de Justiça de Haia. Esta Convenção foi ratificada pelo Estado brasileiro em 1989. Posteriormente foi criada, com base no texto dos tratados internacionais ratificados pelo país, a Lei $\mathrm{n}^{\mathrm{o}}$. 9.455, de 7 de abril de 1997, que define o crime de tortura e dá as providências legais em relação ao mesmo, no âmbito do direito penal brasileiro.

\footnotetext{
${ }^{11}$ Convenção contra a tortura e outros tratamentos ou penas cruéis, desumanos ou degradantes. Adotada pela Resolução 39/46, da Assembleia Geral das Nações Unidas, em 10 de dezembro de 1984.
} 
No âmbito da proteção regional de direitos humanos, a Convenção Americana de 1969, conhecida como Pacto de São José da Costa Rica, ratificada pelo Estado brasileiro em 1992, proibiu a tortura e demais tratamentos degradantes, e, posteriormente, a Convenção Interamericana Para Prevenir e Punir a Tortura, de 1985, fez o mesmo.

Ainda segundo a Convenção Interamericana, ratificada pelo país em 1989, serão responsáveis pelo delito de tortura: Os empregados ou funcionários públicos que, atuando nesse caráter, ordenem sua comissão ou instiguem ou induzam a ela, cometam-no diretamente ou, podendo impedi-lo, não o façam; e as pessoas que, por instigação dos funcionários ou empregados públicos a que se refere a alínea $a$, ordenem sua comissão, instiguem ou induzam a ela, cometam-no diretamente ou nele sejam cúmplices (artigo $3^{\circ}$ ). Na esteira da Era da Responsabilização Individual dos violadores de direitos humanos, mormente os agentes públicos, a Convenção determina que "o fato de haver agido por ordens superiores não eximirá da responsabilidade penal correspondente".

Assim, em atendimento à função promocional do direito, tanto o princípio da dignidade humana, como os princípios da democracia e da prevalência dos direitos humanos impõem a máxima eficácia aos textos constitucionais e aos tratados internacionais ratificados pelos Estados.

\section{Anistia brasileira, (in)justiça de transição e a tortura}

A ruptura com o regime ditatorial no Brasil (1964-1985) resultou na inauguração de uma ordem constitucional diferenciada das que lhe antecederam, mormente num aspecto: a proteção dispensada aos direitos e garantias fundamentais, numa dimensão sem precedentes no constitucionalismo brasileiro. Ou seja, apesar de o Brasil sempre ter lhe dedicado um espaço (tópico) nas suas constituições, somente em 1988, cuidou-se do tema com o relevo merecido e necessário e os princípios fundamentais estão plasmados logo no título I da Constituição, dentre eles, o princípio da dignidade da pessoa humana e o princípio da prevalência dos direitos humano.

A Constituição da República Federativa do Brasil de 1988, elaborada pelo Poder Constituinte de 1987/1988, considera a tortura crime inafiançável e insuscetível de graça ou anistia. A Constituição positivou o crime de tortura no título II, que trata dos direitos e garantias fundamentais dos brasileiros e estrangeiros residentes no pais. Os direitos e garantias fundamentais estão diretamente relacionados com os princípios fundamentais, dentre eles a dignidade da pessoa humana. 
Proibir a tortura e os tratamentos cruéis, desumanos ou degradantes faz parte desse compromisso constitucional brasileiro no final do século XX. Um compromisso do Brasil e de outras das sociedades pós-conflitos com o Direito Internacional dos Direitos Humanos que desaprova tais práticas ${ }^{12}$

A preocupação internacional com a tortura e sua consequente inclusão no rol dos crimes imprescritíveis contra a humanidade deu-se a partir do término da Segunda Guerra Mundial, ocasião em que o mundo se voltou para a criação de mecanismos jurídicos para a proteção da dignidade da pessoa humana.

Com a Constituição de 1988, o Estado brasileiro aderiu ao constitucionalismo contemporâneo, como o fizeram os países europeus, por exemplo as Constituições portuguesa (1976) e espanhola de (1978).

Na seara internacional, ainda que a República Federativa do Brasil já tivesse aderido a importantes tratados e convenções ${ }^{13}$, com o movimento democrático deflagrado em 1985 e a mudança de postura frente à necessidade de proteção aos direitos humanos, avançou-se significativamente no diálogo com os organismos internacionais e na assunção de obrigações perante estes. A Constituição de 1988 em seu artigo $4^{\circ}$ estabelece que o Estado brasileiro regese nas suas relações internacionais pelo princípio da "prevalência dos direitos" (art. $4^{\circ}$ inciso II). Fortalecendo, assim, seu compromisso com o direito internacional dos direitos humanos.

Em relação ao sistema global - Organização das Nações Unidas -, por exemplo, instrumentos tais como o Pacto Internacional dos Direitos Civis e Políticos, Pacto Internacional dos Direitos Econômicos, Sociais e Culturais foram ratificados pelo Brasil em 1992. A Convenção contra a Tortura e outros Tratamentos ou Penas Cruéis, Desumanos ou Degradantes foi ratificada em 1991.

\footnotetext{
${ }^{12}$ Embora a prática da tortura acompanhe toda a história da humanidade, ela surge textualmente de forma explícita na idade média, no contexto de uma Europa cristã subjugada à igreja católica e aos senhores feudais. Nos processos criminais dos tribunais eclesiásticos e no Tribunal do Santo Ofício a tortura tornou-se a "rainha das provas e a rainha dos suplícios" (PETERS, Edward. História da Tortura. Trad. de Pedro Silva Ramos. Lisboa: Círculo de Leitores, 1996, p. 47). No medievo o suplício consistia na pena corporal aplicada para provocar sofrimento na pessoa do criminoso com o intuito de obter a verdade, por meio da confissão do crime pelo qual foi acusado. Tinha um caráter de justiça, pois por meio dela a justiça era alcançada pelos Tribunais cristãos, uma vez que a verdade das acusações era ao final comprovada e, portanto, de forma legítima, a pena ao culpado já estava se impondo no momento do suplício; e tinha um caráter pedagógico, pois as cicatrizes e a feridas eram ostentadas como o triunfo da justiça, e assim se mantinha o controle social. (FOUCAULT, Michel. Vigiar e Punir: História da violência nas prisões. $13^{\mathrm{a}}$ ed. Petrópolis: Editora Vozes, 1996, p.34/35). O termo suplício foi sendo paulatinamente substituído pelo termo tortura a partir do século XVIII. No final do século XX, após o julgamento de Nuremberg, o termo se consolidou nos instrumentos internacionais de proteção de Direitos Humanos e nas cartas constitucionais dos Estados.

13 Acordos internacionais juridicamente obrigatórios, que se constituem em fonte primária do Direito Internacional.
} 
Da mesma forma, em relação ao sistema regional - Organização dos Estados Americanos (OEA) - ratificou-se a Convenção Americana de Direitos Humanos (conhecida como Pacto São José da Costa Rica), em 25 de setembro de 1992. E, Convenção Interamericana para Prevenir e Punir a Tortura, adotada pela Assembleia da OEA em 1985, também foi ratificada pelo Estado brasileiro em 1989.

Os textos internacionais definem crime contra a humanidade como sendo todo ato desumano, contra a população civil ou num ambiente hostil de conflito generalizado, sendo necessário, ainda, para caracterizá-lo que estas condições sejam conhecidas pelo agente do ilícito. $^{14}$

Instado a se manifestar sobre a extensão da anistia concedida pela Lei $6.683 / 79$ aos crimes comuns praticados por agentes da repressão contra os seus opositores políticos, o Supremo Tribunal Federal (STF), no julgamento da Arguição de Descumprimento de Preceito Fundamental (ADPF) núm. 153, realizado em 29 de abril de 2010, por sete votos a dois, decidiu pela constitucionalidade da Lei $6.683 / 79$, que, conforme seu art. $1^{\circ}$, concedeu anistia a todos quantos, no período compreendido entre 02 de setembro de 1961 e 15 de agosto de 1979, cometeram crimes políticos ou conexo com estes, aos que tiveram seus direitos políticos suspensos e aos servidores da Administração Direta e Indireta, de fundações vinculadas ao poder público, aos Servidores dos Poderes Legislativo e Judiciário, aos Militares e aos dirigentes e representantes sindicais, punidos com fundamento em Atos Institucionais e Complementares. Ou seja, o Supremo tribunal Federa manteve a interpretação de que a lei de anistia de 1979 assegura a anistia ampla, geral e irrestrita, alcançando tanto as vítimas como os violadores de direitos humanos, no período de ditadura miliar brasileira.

A razão de decidir consistiu na tese de que a lei resultou de um acordo nacional, entre diversos setores da sociedade civil, não sendo cabível a sua revisão. Ainda para aquele órgão julgador, não poderia o Judiciário avançar sobre a competência do Legislativo, pois que somente a este caberia a pretendida revisão.

Diferentemente de como o assunto fora tratado no Supremo Tribunal Federal, não houve de fato uma conciliação nacional para a promulgação da Lei de Anistia de 1979, a qual foi aprovada com 50,61\% (cinquenta vírgula sessenta e um por cento) dos votos, ou seja, por uma diferença de apenas 05 (cinco), num momento em que o partido do governo, a ARENA (Aliança Renovadora Nacional), detinha maioria no Congresso Nacional, em função da eleição

\footnotetext{
${ }^{14}$ GOMES, Luiz Flávio; MAZZUOLI, Valério de Oliveira, op. cit, 2011, p.88.
} 
indireta de parlamentares. Logo, a lei foi resultado, na verdade, de uma forte ingerência do Executivo sobre o Legislativo, não prosperando, portanto a tese do acordo nacional.

$\mathrm{Na}$ oportunidade em que houveram de se pronunciar acerca dos crimes de lesa humanidade cometidos durante seus respectivos regimes ditatoriais, as cortes argentina, chilena e uruguaia, por exemplo, invalidaram os atos normativos internos que concediam anistia aos ex-militares acusados dos referidos crimes. Foi reconhecida a necessidade de preservação do direito à verdade e à justiça, bem como o dever de investigar os casos de violação a direitos humanos e punir os culpados.

Pronunciou-se a Corte Interamericana, com base na Convenção Americana de Direitos Humanos, decidindo que a Lei de Anistia no Brasil era inconvencional e prescrevendo uma série de obrigações para o Estado brasileiro para que procedesse, enfim, à identificação e punição dos responsáveis pelo desaparecimento de pessoas durante as operações militares na região do Araguaia...

Considerou-se, preliminarmente, que crimes contra a humanidade são imprescritíveis, não sendo suficiente a alegação de que, por ter o Brasil reconhecido a jurisdição contenciosa da Corte somente em dezembro de 1998, ela não poderia conhecer fatos anteriores, pois que tanto alguns dos delitos sob análise tinham caráter contínuo e permanente quanto os fatos e omissões estatais se protraíram para além de 1998.

O objeto da demanda internacional não foi a revisão da sentença da Corte Suprema, para constituir-se numa "quarta instância", mas a verificação do (des) cumprimento por parte do Estado Brasileiro do seu dever, assumido internacionalmente ao aderir à Convenção Americana em 1992, de garantir proteção judicial às vítimas de violações de direitos humanos, de esclarecer a verdade e punir os responsáveis pelos atos criminosos. As alegações de direito penal, como prescrição, vedação do bis in idem e irretroatividades foram desconsideradas.

Ponderou-se ademais que a realização de um controle de convencionalidade, como requerido, é perfeitamente possível, pois que se analisa a compatibilidade do ato normativo questionado diante das obrigações internacionais contraídas pelo Estado à luz da Convenção Americana, configurando uma obrigação do Poder Judiciário local aferir, outrossim, a compatibilidade das normas internas com os tratados internacionais.

Concluiu-se, portanto, pela negação da anistia aos agentes da repressão, afastando as disposições da lei que impediam a investigação e sanção das graves violações cometidas durante o episódio da Guerrilha do Araguaia, pela incompatibilidade jurídica do ato interno com a Convenção Americana, bem como pela responsabilidade da República Federativa do 
Brasil pela violação permanente daquele tratado internacional por ato omissivo, qual seja, ainda não ter investigado as dezenas de casos de desaparecimento forçado.

\section{Conclusão}

O estudo da tortura, após a Segunda Guerra Mundial, tem um extraordinário alcance jurídico-científico, uma vez que, por meio dele, é possível investigar textos internacionais referentes à proteção da pessoa humana, a importância da aplicação das normas constitucionais dos Estados na perspectiva do sistema de cooperação internacional contra o tratamento desumano, cruel e degradante de todo e qualquer indivíduo.

Estudar os erros praticados contra o ser humano é importante para que se possam melhorar os instrumentos de cuidado com a vida, a dignidade e a justiça em uma base global de humanidade.

Ainda hoje o que se vislumbra é a falta de efetividade das normas internas, dos tratados e convenções internacionais na vida prática de milhões de pessoas, demonstrando, assim, que existem diversos fatores reais de poder com os quais os Estados continuem desrespeitando o ordenamento jurídico interno e internacional.

A tortura é um crime que constitui uma ameaça à paz, à segurança e ao bem-estar. A dignidade da pessoa humana como princípio, na Declaração Universal dos Direitos Humanos de 1948, hoje é reconhecidamente uma conquista determinante e transformadora da ordem jurídica interna e internacional.

O Estatuto de Roma foi essencial para a construção de uma tipificação concreta dos crimes contra a humanidade -, e a possibilidade de submeter ao Tribunal Penal Internacional os responsáveis pela prática de tais crimes. Tipificar a tortura como crime contra a humanidade atesta a importância de uma maior preocupação com a vida e com as pessoas em si mesmas consideradas.

\section{Referências bibliográficas}

DOURADO, Denisart. Tortura. 2a ed. Leme: Editora de Direito, 2001, p.179.

FERNANDES, David Augusto. Tribunal penal internacional: a concretização de um sonho. Rio de Janeiro: Renovar, 2006, p. 126. 
FOUCAULT, Michel. Vigiar e Punir: História da violência nas prisões. 13 ${ }^{\mathrm{a}}$ ed. Petrópolis: Editora Vozes, 1996, p.34/35).

FOURNET, Caroline. Genocide and Crimes Aganist Humanity. Misconceptions and confusions in french law and practice. Studies in international and comparative criminal law. Oxford: Hart Publishing, 2013, p.32.

MAZZUOLI, Valério de Oliveira. Tribunal penal internacional e o direito brasileiro. São Paulo: Premier Máxima, 2005.

MAZZUOLI, Valério de Oliveira. Curso de Direito Internacional Público. São Paulo: Revista dos Tribunais, 2010, p.75.

MELLO, Celso Renato Duvivier de Albuquerque. Curso de direito internacional público. Rio de Janeiro / São Paulo: Renovar, 2004, p 974.

SIKKINK, Kathryn. A Era da responsabilização: a ascensão da responsabilização penal individual. In: A anistia na era da responsabilização: o Brasil em perspectiva internacional e comparada. Brasília: Ministério da Justiça, Comissão de Anistia; Oxford: Oxford University, Latin American Centre, 2011. p. 34. 


\title{
DIREITOS HUMANOS E CONFLITOS ARMADOS: AS CONTRADIÇÕES E PERSPECTIVAS DA COMUNIDADE INTERNACIONAL
}

\author{
Kiwonghi Bizawu \\ Escola Superior Dom Helder Câmara - Belo Horizonte-MG
}

\section{Resumo}

O presente artigo objetiva analisar a relação entre o Direito internacional humanitário e o Direito Internacional dos Direitos Humanos em tempo de conflitos armados, tendo em vista as contradições que emanam da interpretação do Direito Internacional perante o Conselho de Segurança da organização das Nações Unidas (ONU) quando tais conflitos ou guerras envolvem as grandes potências. Buscam-se, ainda, novas perspectivas para pacificar a humanidade. Utilizar-se o método dedutivo mediante a pesquisa descritiva.

Palavras-chave: direito internacional humanitário, direito internacional dos direitos humanos, ONU, contradições, perspectivas.

\begin{abstract}
Resumen/Résumé
This article aims to analyze the relationship between the International Humanitarian Law and the International Human Rights Charter in times of armed conflict, in view of the contradictions that emerge from the interpretation of international law before the United Nations (UN) Security Council, when such conflicts or wars involve the great powers. It also seeks new perspectives to pacify humanity. Use the deductive method using the descriptive search.
\end{abstract}

Keywords/Palabras-claves/Mots-clés: international humanitarian law, international human rights law, UN, contradictions, prospects.

\section{Introdução}

Considerando os conflitos armados atuais e as guerras vigentes em vários cantos do mundo, pode-se observar que os Estados não aprenderam a lição das grandes guerras mundiais que dizimaram milhões de seres humanos e trouxeram à humanidade indizíveis sofrimentos e 
inimagináveis crimes com alcance internacional, provocando indignação planetária diante das atrocidades cometidas pelos beligerantes.

Há de ressaltar que tais crimes chocaram a consciência da humanidade a ponto de a comunidade internacional buscar meios propícios e medidas eficazes para coibir as violações sistemáticas e gravíssimas dos direitos humanos com a criação do Tribunal Penal Internacional (TPI) cuja sede se encontra na cidade de Haia na Holanda.

Percebe-se, para tanto, que os crimes "de maior gravidade que afeta a comunidade internacional" (ESTATUTO DE ROMA, Preâmbulo) são uma verdadeira ameaçada à paz e a segurança internacional. Para isso, faz-se necessário preservar as gerações vindouras do flagelo das guerras e garantir, ao mesmo tempo a efetividade da proteção dos direitos humanos e a efetivação da justiça internacional.

O direito internacional humanitário e o direito internacional dos direitos humanos são dois ramos do Direito Internacional que não são antagônicos, mas complementares na era dos conflitos armados. Não há mais dúvida, partindo dos acontecimentos que levaram à criação do Comitê Internacional da Cruz vermelha, tendo em vista a batalha de Solferino (1859), a Convenção de Genebra de 1949, en passant pelos conflitos armados no Iraque, no Afeganistão, no território da Palestino e em alguns países africanos tais quais a República democrática do Congo, a Libéria e Ruanda com o genocídio de 1994, quanto à aplicabilidade dos direitos humanos à situações de guerra com suas consequentes atrocidades e crimes hediondos.

O presente artigo objetiva analisar a relação entre os dois institutos jurídicos do Direito Internacional em tempos de conflitos armados, buscando a sua complementaridade e influência no que tange aos direitos humanos e à proteção internacional do indivíduo.

É importante reconhecer que o Direito internacional evolui em função dos acontecimentos globais, regionais e locais, bem como das possibilidades e conveniências entre Estados e das ideias veiculadas pelas grandes potências que se apoderaram das mídias influentes no cenário mundial por uma questão de poder e hegemonia.

Problematiza-se o tema em tela quanto à questão de saber como o direito internacional humanitário e o direito internacional dos direitos humanos podem ser aplicados de uma maneira coerente e convincente sem contradições e sem parcialidade nos conflitos armados? Nota-se, diante da fragmentação do direito internacional, a vontade de proteger o ser humano em sua dignidade, coibindo-se os crimes inimagináveis com alcance internacional, dando-se aos Estados mecanismos de punir os responsáveis de tais crimes pela criação de jurisdições penais nacionais às quais é complementar o Tribunal Penal Internacional, caracterizado pela sua permanência e independência no âmbito da Jurisdição das Nações Unidas. 
Para a consecução dos objetivos propostos, utilizar-se-ão o método dedutivo e a pesquisa descritiva com foco em Convenções, Tratados e Protocolos internacionais, bem como o direito internacional no sistema global, comprovando a complementaridade e a interação entre o direito internacional humanitário e o direito internacional dos direitos humanos e, concluindose, desse modo pela sua recíproca efetividade nos conflitos armados em que ocorrem as graves violações dos direitos humanos, acarretando, portanto, na concretude dos fatos as indenizações às vítimas de atrocidades cometidas pelas partes beligerantes, suscetíveis de condenação perante os tribunais penais nacionais ou internacionais.

\section{Conflitos Armados e Direitos Humanos}

Neste trabalho, emprega-se o termo "conflito armado" em substituição à "guerra". Isso se enquadra no esforço da comunidade internacional, através da Carta das Nações Unidas (1945), em proibir o uso da força por um Estado contra outro, e em declarar guerra. Embora, evita-se falar num "estado da guerra", reconheça-se a existência de conflitos armados no sistema internacional.

Esses conflitos são analisados por diferentes prismas de Direitos Humanos e Direito Internacional Humanitário, ainda que haja convergência entre si, no que concerne à proteção de seres humanos.

No âmbito do Direito Internacional Humanitário, diferenciam-se dois tipos de conflitos armados. O primeiro opõe-se a dois ou mais Estados. O segundo, considerado conflito armado não internacional, abrange confrontos entre forças governamentais e grupos armados não governamentais, ou entre os próprios grupos. Essas separações foram introduzidas nas Convenções de Genebra de 1949. O Artigo $2^{\circ}$ da referida Convenção, determina: "além das provisões que devem ser implementadas em tempo de paz, as mesmas aplicam-se a todos os casos de guerra declarada ou algum tipo de conflito armado, que possa surgir entre duas ou mais das Altas Partes Contratantes, mesmo que o estado de guerra não seja reconhecido por uma delas ${ }^{1}$ " (ICRC, 1949, p. 81).

As “Altas Partes Contratantes” significam os Estados, considerados principais sujeitos da sociedade internacional. Essa sociedade é formada, para além do Estado, por: “organizações internacionais intergovernamentais, com reflexos voltados também para a atuação dos indivíduos no plano internacional" (MAZZUOULI, 2010, p. 44). O Estado é, portanto, dotado

\footnotetext{
${ }^{1}$ In addition to the provisions which shall be implemented in peacetime, the present Convention shall apply to all cases of declared war or of any other armed conflict which may arise between two or more of the High Contracting Parties, even if the state of war is not recognized by one of them.
} 
de capacidade plena para ação no nível interno e externo. Nesse construto, a definição weberiana aponta que se trata da "comunidade humana que pretende o monopólio do uso legítimo da força física dentro de um determinado território” (WEBER, 2003, p. 56).

O uso legítimo da coação física é que diferencia o Estado de qualquer outra organização e lhe confere responsabilidades únicas no que tange à proteção da população e promoção dos seus direitos. Contudo, o sistema internacional, tem se tornado cada vez mais complexo e plural, consoante a emergência de novos temas, como o terrorismo outros atores na qualidade de grupos terroristas, capazes de colocar em questão a segurança e a estabilidade internacional. Essa configuração informa nova dinâmica nos conflitos.

O Tribunal Penal Internacional para Ex-Iugoslávia (TPIY) considerou que o conflito armado existe "sempre que há um recurso às forças armadas entre Estados ou uma violência armada prolongada entre autoridades governamentais e grupos armados organizados ou entre tais grupos dentro de um Estado" ${ }^{2}$

Em face de nova realidade, o Direito Internacional Humanitário deve ser aplicado desde o início do conflito e se estender a cessação das hostilidades, até o alcance e conclusão de uma paz generalizada. No caso de conflito interno, a vigência se dá quando um acordo de paz é alcançado (YCTI, 1995, para. 70).

A consideração conceitual da referida Corte Internacional tem sido adotada por diversas organizações e entidades internacionais. Contudo, a aplicação da lei depende da análise das condições factuais informadas pela situação no território onde se gerou o conflito.

O propósito deste artigo é tratar de Conflitos Armados no âmbito dos direitos humanos. A parte relevante é a preservação da dignidade e humanidade de todas as pessoas afetadas pelo conflito. Atualmente, as recomendações da Comissão sobre os Direitos Humanos da Assembleia Geral da ONU versam sobre as obrigações que as partes beligerantes devem cumprir no que tange aos direitos das pessoas afetadas pelos conflitos. São os direitos inerentes a todos os seres humanos, sem distinção de nacionalidade, sexo, origem étnica, cor, língua, religião.

O Estado deve proteger os direitos fundamentais dos indivíduos quando se mostra incapaz da referida proteção ao longo do território, faz-se necessário a cooperação internacional com a finalidade de preservar a vida da população civil e evitar a escalada de conflito para cenários extremos, como crimes contra a humanidade e genocídios.

\footnotetext{
${ }^{2}$ We find that an armed conflict exists whenever there is a resort to armed force between States or protracted armed violence between governmental authorities and organized armed groups or between such groups within a State.
} 
O Direito Internacional dos Direitos Humanos lida com as obrigações dos Estados na promoção dos direitos humanos e nas liberdades fundamentais de indivíduos ou grupos. Os Estados devem, portanto, criar condições para que os indivíduos tenham acessos a um dado direito. Nesse contexto, o direito à alimentação adequada deve ser um dos primeiros a ser realizados (UNITED NATIONS, 2011). Na verdade, Protocolos Adicionais da Convenção de Genebra, proíbe a fome como um método de combate. A alimentação é a dimensão mais importante desses direitos na medida em que faculta aos indivíduos a capacidade e consciência de resolver outras questões relevantes. Além da obrigação de proteger, os Estados devem prevenir, investigar e punir violações de direitos humanos cometidos por terceiros. A proteção tem peso diferenciado. A população civil tem prioridade em relação aos combatentes e eles não podem ser alvos de ataques.

Determinados conflitos, no entanto, não apresentam sinais de términos para um horizonte curto de tempo e a vida da população afetada precisa ser protegida. Dessa forma, uma vez que os direitos humanos são estendidos durante o conflito, eles devem abranger os direitos económicos, sociais e culturais. Tais direitos incluem: saúde, educação, segurança e emprego (LUBELL, 2005). A grande questão, todavia, é como promover e implementar tais direitos em espaços culturais e políticos diferentes daqueles onde a população se fixava? Para isso, é preciso entender que conflitos causam deslocamentos internos, forçando o convívio entre pessoas de culturas, religiões e pensamentos diferentes.

Os apontamentos, supracitados, sofrem interpretações mediante contextos, interesses e atores envolvidos. Existem evidências que apontam a disparidade entre as leis e a realidade, suscitando a seguinte afirmação: "violações de direitos humanos e ataques aos civis acontecem no âmbito de conflitos armados!" Na verdade, as atuais tecnologias e armas, como os Drones ${ }^{3}$ aumentaram o alcance e danos dos novos conflitos. Assim sendo, indaga-se: na era em que conflitos são gerenciados à distância como são garantidos os direitos humanos à população civil?

Para Edson Damas (2009),

Apesar disso, a ideia de universalidade dos direitos humanos continua presente no pensamento dos juristas da contemporaneidade75 que se esmeram, entre outras hipóteses, para desenvolver uma ideologia universalista progressista, mais sintonizada com o momento de se repensar as funções do Estado e promover encontros com os outros diferentes. (DANTAS, 2009, p. 44).

\footnotetext{
${ }^{3}$ Guerra dos Drones: aviões não tripulados massacram civis em zonas de conflito. Disponível em: http://revistagalileu.globo.com/Revista/Common/0,EMI344449-17770,00GUERRA+DOS+DRONES+AVIOES+NAO+TRIPULADOS+MASSACRAM+CIVIS+EM+ZONAS+DE+CO NFLIT.html.
} 


\section{Desafios da Proteção dos Direitos Humanos no âmbito de Conflitos Armados}

A garantia dos direitos humanos no âmbito de conflitos armados encontram diversas barreiras. Uma delas é a tentativa de se adaptar os conceitos e pressupostos de uma realidade a culturas e línguas diferentes. Oportuno, exemplificar, que enquanto a Convenção Europeia sobre o tema realiza uma leitura detalhada do direito internacional humanitário, com ênfase no direito à vida e à liberdade e segurança, a Carta Africana efetua uma leitura menos detalhada desses direitos, o que faculta margem de manobra considerável para a implementação do direito humanitário. A Carta apenas protege o direito à vida contra as privações arbitrárias e o direito à liberdade contra qualquer privação de liberdade "exceto por razões e condições previamente estabelecidas por lei, excluindo igualmente a prisão ou detenção "arbitrária"” (HAILBRONNER, 2016, p. 356).

Na verdade, a base formadora das várias sociedades africanas, por exemplo, refere-se à comunidade e humanidade. Sendo a comunidade um espaço de realização do indivíduo. Isso importa para afirmar que a comunidade não reprime o indivíduo. Nesse contexto, os direitos humanos estão constrangidos pelos conceitos da humanidade comunidade. Em outras culturas, como a Islâmica, o esforço é reinterpretar os direitos humanos em conformidade com os deveres dos governos e dos indivíduos. Isto é, os direitos surgem em razão das ações perpetuadas (DONNELLY, 1982).

Essas singularidades não afastam tais culturas da perspectiva ocidental, pelo contrário, há um ponto de conexão fundamental que se refere ao respeito dos direitos humanos e garantia das condições materiais e imateriais para a manifestação da dignidade humana. Compreender e respeitar essas singularidades proverão subsídios para uma proteção efetiva dos direitos da população afetada (LUTZ, 2014).

Existem dificuldades de ordem normativa, uma delas refere-se à aplicabilidade extraterritorial das obrigações dos direitos humanos. Este desafio manifesta-se em situações em que um Estado opera fora da sua fronteira, tendo que manobrar e agir num espaço de respeito à soberania do Estado e verificar o limite de interferência nos assuntos internos.

A proteção aos direitos humanos pode, no entanto, acontecer sob as áreas efetivamente controladas pelo Estado. O grande desafio é, contudo, conceituar o que se entende por controle efetivo. Vale sublinhar, que nem todos os contextos de controle ou presença do Estado favorece a livre promoção de direitos humanos. Tais direitos são mais bem manifestados e garantidos em contextos democráticos. Há outros casos em que os direitos humanos se estendem 
territorialmente quando o Estado está a administrar um centro de detenção fora da sua fronteira (LUBELL, 2005).

Não obstante, a importância da aplicabilidade dos direitos humanos nos conflitos, uma questão relevante é se os órgãos de direitos humanos estão realmente prontos para examinar as situações in loco. Isto é: "se os órgãos dos direitos humanos têm um mandato e expertise necessários para avaliar as operações militares” (LUBELL, 2005, p. 740, tradução nossa) ${ }^{4}$.

Um tema frequente é a independência dos respectivos órgãos em participar na resolução dos problemas. A dependência financeira e a baixa capacidade de enforcement limitam o raio de atuação desses órgãos. Elas ocupam apenas do monitoramento e recomendações da situação. Por exemplo, o Comitê dos Direitos Humanos das Nações Unidas submete os seus relatórios ao Conselho de Segurança que tem a capacidade de ação. Esse ponto é essencial, pois, assinala que as instituições podem ser usadas como espaços de poder e instrumentos para materialização dos interesses dos Estados poderosos.

\section{Garantia dos direitos humanos nos conflitos pelo mundo: entre humanidade e pragmatismo}

Enquanto se discute a aplicabilidade dos direitos humanos, em tempos de conflitos armados, pessoas inocentes pagam com a vida as atrocidades e efeitos colaterais dos conflitos. Para entender este assunto, é preciso visualizar a dinâmica dos conflitos influenciada por interesses e políticas dos principais países envolvidos.

Há uma tendência de os países ocidentais (Estados Unidos de América e países europeus) usarem os direitos humanos como uma ferramenta política e chamar a atenção da comunidade internacional às violações em regiões estratégicas do mundo.

Os países pobres são caracterizados como espaços conflituosos, que, por conseguinte, fomentam a violação dos direitos humanos. Isso justifica a necessidade da participação e a intervenção dos países ocidentais na resolução dos problemas e proteção da população civil, portanto, os direitos humanos são sensíveis e mobilizam a comoção da comunidade internacional.

Quando os temas de direitos humanos entram na agenda da política externa, três dimensões são reveladas, de acordo com Soosaipillai (2015). Primeiro: os direitos humanos são usados como uma arma contra um Estado inimigo para alcançar interesses nacionais;

\footnotetext{
${ }^{4}$ whether human rights bodies have the mandate and necessary expertise to evaluate military operations.
} 
segundo: países ocidentais resistem a condenar ou a criticar direitos humanos em regiões pobres se a condenação impedir a realização de interesses domésticos; desse modo, a terceira dimensão aponta que os direitos humanos não ganham suporte quando o impacto no interesse nacional é ausente ou muito baixo.

Como evidência, o autor supracitado mobiliza o conflito entre as forças armadas do Estado de Sri Lanka com a minoria étnica Tamils, ocorrido em 1983. Em 2009, com o fim do conflito entre as forças armadas do Estado e Liberation Tigers of Tamil Eelam (LTTE), os Estados Unidos ficaram satisfeitos com a promoção dos direitos humanos.

A reviravolta aconteceu em 2012, quando os Estados Unidos e aliados europeus acusaram o Sri Lanka de sérias violações de direitos humanos, introduzindo resoluções condenatórias no Conselho de Direitos Humanos da ONU. A questão emergente é: Por que os EUA, que apoiaram o Sri Lanka durante o conflito, encabeçaram uma campanha contra o mesmo no Conselho de Direitos Humanos?

O Conselho de Direito Humanos elabora resoluções e recomendações ao Conselho de Segurança, sendo este o órgão que decide, no qual, uns dos membros permanentes são os Estados Unidos, França e Inglaterra.

Sri Lanka havia elaborado um documento apontado que não ocorreu violação de direitos humanos durante o referido conflito, este documento foi assinado por 29 países em desenvolvimento e pobres. O documento recomendava que os direitos humanos não devessem ser usados como instrumentos políticos por parte de Estados fortes (SOOSAIPILLAI, 2015).

A mudança de postura dos Estados Unidos e de seus aliados é justificada pelo interesse geopolítico na região do Oceano Índico e no Sul da Ásia, interesse semelhante manifestada pela China que se configura na região como uma adversária. Além disso, Sri Lanka começou a servir de exemplo para os demais países que estavam a lidar com a eliminação do terrorismo e os Estados Unidos não gostaram da ideia de o país se tornar um modelo internacional da resolução de conflitos sem a sua aprovação (SOOSAIPILLAI, 2015).

Esse exemplo confirma que a preocupação e a proteção aos direitos humanos podem ser relegadas ao segundo plano quando questões de interesse nacional dos países fortes estão em causa. Os conflitos atuais complementam o caso citado, especialmente ao evidenciar que regiões estratégicas atraem mais atenção da comunidade internacional, quando a situação tende a ameaçar a estabilidade da ordem internacional. Evidências provenientes do Oriente Médio e, especificamente, da guerra civil na Síria, fazem parte desta inferência.

Para tal, faz-se necessário, enquadrar esses conflitos no chamado "Primavera Árabe". A Primavera Árabe originou-se a partir de revoltas da população que visava denunciar sistemas 
políticos e econômicos obsoletos que não correspondiam às realidades da maioria da população. Sistemas esses aflorados no período pós-independência com estabelecimentos dos regimes políticos corruptos e autoritários sobre amparo dos países ocidentais.

Eventos internacionais intensificaram as revoltas, principalmente a crise de subprime estadunidense de 2008, que atingiu tanto as economias periféricas como as centrais do mundo, levando com que o aumento no preço de petróleo afetasse grandes produtores africanos e do Oriente Médio. A crise refletiu-se no aumento dos preços dos produtos alimentícios, agravando a situação alimentícia no Chifre da África, em 2011.

A Primavera Árabe provocou quedas de governo em Tunísia Egito e Líbia. A intervenção internacional com a justificativa de promover valores democráticos e proteção dos direitos humanos, apenas aconteceu quando os eventos mudaram da Península Arábica para o Golfo Pérsico; ou quando houve transbordamento de manifestação da Tunísia para o Egito, país central na política externa estadunidense na região. Essas revoltas constituíram-se em oportunidades para alterar as negociações com alguns países. A morte do Muammar al-Gaddafi simboliza isso, pois o presidente líbio iniciara a renegociação dos contratos de exportações petrolíferas para França e o bloqueio às empresas francesas que tentavam explorar a água no deserto Sul da Líbia, exportando-a para a costa mediterrânea, Vale adicionar, a recusa do presidente líbio para a instalação de base militar-Comando dos Estados Unidos para África(AFRICOM) .

No caso do Egito é sintomática a adequação do discurso do Barack Obama mediante a escalada do conflito. No primeiro momento o discurso foi a favor da paz mundial, preservação dos direitos humanos, liberdade de expressão e de associação. Em seguida, Mubarak baniu acesso às mídias sociais e mesmo assim os EUA continuaram a considerar o governo egípcio como um grande aliado. Porém, mediante a presença de tanques de guerra nas ruas, o Obama começou a sugerir transição no Egito. Os EUA pediram mudança de regime na medida em que a crise no país africano pudesse afetar diretamente os seus interesses econômicos e petrolíferos e a própria economia global.

A priorização desses interesses explica o caos em que se encontram a região do Norte da África. De fato, não se verificou proteção aos direitos humanos e a implementação de princípios democráticos. Lado outro, a intervenção no conflito, assinala que a mudança política ou econômica nessas regiões só acontece sobre o aval dos Estados Unidos e de seus aliados e quando afetar diretamente os interesses nacionais.

Países em desenvolvimento, e que são consideradas potências médias do Sul, como o Brasil, África do Sul e Índia, exigiram Responsabilidade ao Proteger nas intervenções externas, 
obrigando a proteção de civis em conflitos armados. A mudança no conceito da "Responsabilidade de Proteger" para "Responsabilidade ao proteger" foi informada pelos históricos das graves violações de direitos humanos da população civil. O exemplo paradigmático é o genocídio de Ruanda, em 1994. Ademais, a Responsabilidade de Proteger, estava a ser explorada para fins egoístas de política externa e como uma ferramenta para acertar as contas com os governos com os quais tinham diferenças (LANDSBERG, 2015).

A recomendação correspondia também ao uso da força militar em situações extremas, como genocídios, crimes de guerras e contra a humanidade. Ou seja, utilizado como "último recurso diante da incapacidade do Estado no exercício da sua responsabilidade de proteger e após o esgotamento de todos os meios pacíficos" (BELÉM LOPES, SALIBA, 2016, p. 1).

Define-se, então, a agressão como "o uso da força armada por um Estado contra a soberania, a integridade territorial ou independência política de um outro Estado, ou de toda outra maneira incompatível com a Carta das nações Unidas".

Repara-se que, no art. $2^{\circ}$, estipula-se que o uso da força armada em violação da carta da ONU por um Estado, agindo primeiro, constitui a prova suficiente à primeira vista de um ato de agressão, mesmo si o Conselho de Segurança pudesse concluir, conforme a Carta, que estabelecer que um ato de agressão havia sido cometido, não seria justificado, considerando outras circunstâncias pertinentes, incluindo o fato de que os atos em causa ou suas consequências não são de uma gravidade suficiente".

Percebe-se que no caso da ocupação, por exemplo, da República Democrática do Congo pelas forças estrangeiras constitui um ato da agressão que tem embasamento jurídico no art. $3^{\circ}$ da resolução 3314 (XXIX), alínea (a), quando dispõe o seguinte:

"Art. $3^{\circ}$

(a) A invasão ou ataque do território de um Estado pelas forças armadas de um outro Estado, ou toda a ocupação militar, mesmo temporário, resultando de uma tal invasão ou de um tal ataque, ou toda anexão pelo uso da força do território ou de uma parte do território de um outro Estado".

Considerando, portanto, a inviolabilidade do território de um Estado por outro, bem como um dos objetivos essenciais da ONU é manter a paz e a segurança internacionais, tomando medidas coletivas eficazes no intuito de prevenir e de descartar as ameaças à paz e de reprimir qualquer ato de agressão ou uma outra ruptura da paz, a agressão em si torna-se um crime contra a paz internacional. Cabe, no entanto, ao CS determinar a existência de um ato de agressão. 
Todavia, o CS pode interpretar um ato de agressão sob o prisma político, uma vez que suas decisões são mais políticas e menos jurídicas. Nesse sentido aborda Yoram Dinstein, no que diz respeito à agressão, violação da paz ou qualquer outra ameaça à paz, que "não é imperativo para o Conselho determinar especificamente que a agressão foi cometida". (DISTEIN, 2004, p. 175-176).

Ressalta-se no anexo da resolução 2625 (XXV) que o direito internacional está assentado nos princípios de liberdade, de igualdade, da justiça e do respeito dos direitos fundamentais do homem, bem como o de desenvolver as relações amistosas entre as nações independentemente das diferenças de seus sistemas políticos, econômicos e sociais ou de seus níveis de desenvolvimento.

Por isso, faz-se necessário o estrito respeito dos princípios da Carta da ONU e dos que regem o direito internacional concernentes às relações amistosas e a cooperação entre os Estados, de conformidade com a Carta da ONU, incluindo o princípio da não intervenção nos assuntos internos de um outro Estado, como "condição essencial a cumprir para que as nações vivam em paz umas com as outras, porque a prática da intervenção, sob qualquer forma que seja, não apenas constitui uma violação do espírito e do conteúdo da Carta, mas também tende a criar situações que colocam em perigo a paz e a segurança internacionais".

Analisando sob a vertente da intervenção armada de Estados Estrangeiros no leste da RDC sob alegações de perseguir grupos armados suscetíveis de ameaçar a paz e a segurança interna de cada um deles, há de salientar que tal atitude constitui um ato de agressão e pode desencadear da parte do Estado agredido outros atos de violência, mas justificativos da legítima defesa.

Em face das modalidades de agressão, a doutrina fala em agressão direta e agressão indireta que são, porventura, proibidas. A Corte de Justiça tem contribuído bastante ao apreciar casos referentes à intervenção militar em países soberanos em nome de segurança ou legitima defesa preventiva.

É preciso recordar que além da importância do papel importante do CS contido na Carta da ONU, reconhecendo-lhe no art. 39, "o poder discricionário de determinar o que se constitui em ameaça à paz, ruptura da paz e atos de agressão"(JO, 2004, p. 621), em matéria de segurança coletiva, há de invocar também a utilização de uma organização regional pelo CS para o uso da força após esgotar todos os meios pacíficos.

A busca da paz por meios de soluções pacíficas remete a um dos pilares da segurança coletiva constituído por regras de comportamento dos Estados, ou seja, a conduta dos Estados obrigados a solucionar suas controvérsias por meios pacíficos (art. $2^{\circ}, \S 3^{\circ}$ ) da Carta, 
interditando-os a usar da força seja contra a integridade territorial ou independência política de qualquer Estado, seja de qualquer outra maneira incompatível com os Propósitos das Nações Unidas (art. $2^{\circ}, \S 4^{\circ}$ ), salvo caso de legítima defesa individual ou coletiva, conforme o art. $51 \mathrm{da}$ Carta da ONU.

O segundo pilar relativo á segurança coletiva faz parte das medidas coletivas a serem tomadas pelo CS, que detém o poder de qualificar os comportamentos (art. 39), e consequentemente, de designar o(s) culpado (s) e de recomendar, ordenar ou tomar ele mesmo as medidas para manter ou restabelecer a paz e a segurança internacionais, com fulcro nos artigos 40 (medidas provisórias), 41 (medidas que não implicam o uso da força armada) e 42 (medidas militares).

Observa-se, então, a necessidade de recorrer à ONU, através do CS, em caso de ameaça à paz, ruptura da Paz ou agressão à paz, para evitar a anarquia. O Capítulo VII é a chave do uso da força, mas que é praticamente desafiado pela rapidez dos acontecimentos e sua complexidade, bem como por uma nova doutrina que não é mencionada pela Carta, a saber, a legítima defesa preventiva para justificar ataques, ou seja, agressão de um Estado soberano contra outro e invasão de um território sem autorização do CS.

O caso dos conflitos dos Grandes Lagos reforça a importância do uso da força, conforme o capítulo VII da Carta, em face da invasão do território congolês por tropas estrangeiras, como medidas coercitivas para preservar a integridade territorial, a independência política do mesmo, bem como a manutenção da paz e a segurança internacionais, identificando os autores da agressão e graves violações de direitos humanos e do direito internacional humanitário , entregando-os às autoridades judiciárias competentes para serem julgados por crimes de guerra e/ou crimes contra a humanidade.

Os crimes de guerra (war crimes) consistem em infrações aos costumes e leis de guerra, abrangendo ainda maus-tratos, homicídio, deportação de civis dos territórios ocupados para trabalhos forçados ou para trabalhos de prisioneiros de guerra ou de pessoas no mar, morte de reféns, saques de bens tanto públicos quanto privado, aniquilação de aldeia e cidades por motivo fútil ou que não se amare por exigências militares. No conceito dos crimes contra a humanidade (crimes against humanity) encontram-se homicídios, extermínios, escravizações, deportações e todo o qualquer outro ato desumano ou cruel contra civis praticados antes ou no decorrer da guerra, inclusive as perseguições políticas, raciais e religiosas quando praticadas em decorrência de um crime que seja conexo ou que esteja na jurisdição do tribunal. Em sua resolução 95 (I) a Assembleia da ONU afirma que 
Genocide is a denial of the right of existence of entire human groups, as homicide is the denial of the right to live of individual human beings; such denial of the right of existence shocks the conscience of manking, results in great losses to humanity in the form of cultural and other contributions represented by these human groups, and is contrary to moral law and to the spirit and aims of the United Nations.

As considerações feitas sobre a segurança coletiva em que se inserem os conflitos dos Grandes Lagos para serem analisados destacam o papel da ONU e a intervenção das Forças da manutenção da paz na RDC (MONUC), para proibir atos ilícitos, mediante o uso da força armada se necessário dentro de seus limites.

Exige-se, para tanto, uma cooperação entre Estados, dando "às Nações Unidas toda assistência em qualquer ação a que elas recorrerem de acordo com Carta", conforme o art. $2^{\circ}$, $\S 5^{\circ}$, para que as medidas coercitivas sejam eficazes e que prevaleça o respeito aos princípios do direito internacional.

Para Simone Martins Rodrigues, a defesa da autorização para o uso da força em suporte às operações da ONU está refletida no texto da Agenda para a Paz (RODRIGUES, 2000, p. 53).

\begin{abstract}
A Agenda considera que a essência do conceito de segurança coletiva como descrito na Carta está no fato de que, se os meios pacíficos falharem, as medidas previstas no Capítulo VII deverão ser usadas, segundo a decisão do Conselho de Segurança, para manter a paz e a segurança internacional. E o principal fator presente nas operações de manutenção da paz atuais é a falta de capacidade para lidar como os novos problemas que têm surgido nas áreas de conflito, diminuindo cada vez mais sua eficácia e a segurança de suas tropas. (RODRIGUES, 2000, p. 53).
\end{abstract}

Como se pode observar, o presente trabalho destaca a responsabilidade do CS no que diz respeito à busca de solução por meios pacíficos (Capítulo VI da Carta) ao analisar as resoluções sobre a RDC na perspectiva dos conflitos dos Grandes Lagos sob as vertentes geopolíticas e geoestratégicas e, em face da persistência das lutas armadas e violações de direitos humanos e do direito internacional humanitário, aplicar o capítulo VII dentro de suas prerrogativas, autorizando o uso da força, tendo em vista a segurança coletiva alicerçada em medidas coercitivas eficazes e dissuasivas, fazendo, assim, da paz um imperativo do direito internacional.

Todavia, a segurança coletiva não pode apenas ser reduzida à prevenção da guerra, ao uso dos meios coercivos, incluindo militares para dissuadir, reprimir os agressores sob a responsabilidade e autorização do CS, mas exige também um olhar sobre outras formas de desafios em matéria de segurança tais quais, a segurança alimentar, a segurança ambiental (ecológica). 
Em relação à busca da manutenção da paz e da segurança internacionais, a situação atual da África no cenário mundial torna-se um desafio para a comunidade internacional a atacar outros inimigos da paz e da segurança que são a fome, a pobreza, a mortalidade infantil e materna, as doenças como a AIDS/HIV, a malária e outras endêmicas, e o desenvolvimento sustentável do continente africano. Hoje em dia, as operações da manutenção da paz quebraram o paradigma de apenas fazer a guerra, mas são acompanhadas por operações humanitárias devido às milhares de refugiados, vítimas inocentes dos conflitos armados.

\section{Considerações finais}

Observou-se, no decorrer desse artigo, que mudanças significativas ocorreram no direito internacional e houve efetividade da proteção dos direitos humanos diante dos intermináveis conflitos armados com mecanismos protetores criados pela ONU de acordo com a vontade dos Estados, tendo em visto os crimes inimagináveis cometidos nas duas grandes guerras mundiais e, na era dos avanços tecnológicos, os genocídios ocorridos na guerra nos Bálcãs seguida de limpeza étnica de muçulmanos bósnios pelos sérvios (1993), na Ruanda (1994) com os massacres de tutsis e hutus moderados pelos hutus, acarretando nos dois casos a criação de tribunais penais internacionais "ad hoc" na Haia (Holanda) e em Arusha (Tanzânia), um para os crimes na ex-Iugoslávia (TPIY) e o outro para os crimes ocorridos em Ruanda (TPIR).

Mais tarde, seguindo a mesma lógica de acabar com a impunidade dos indivíduos que praticaram crimes de genocídio, crimes de guerra, crimes contra a humanidade e agressão, foi criada O Tribunal Penal Internacional (1998), permanente, independente e complementar com relação aos tribunais penais nacionais.

Daí a necessidade de estender um olhar clínico sobre os acontecimentos mundiais depois da Segunda Grande Guerra Mundial para entender melhor a importância dos dois institutos, a saber, o direito internacional humanitário e o direito internacional dos direitos humanos quanto à efetividade dos direitos humanos em uma humanidade dilacerada pelos conflitos e pelas guerras sem fim.

Buscou-se também analisar, no presente artigo, no âmbito do direito internacional, a bipolarização do mundo, ou seja, a formação de dois blocos para governar o mundo, o capitalismo e o socialismo, levando os Estados à Guerra Fria, temendo uma terceira Guerra Mundial e a vontade de corrigir os erros do passado a fim de que tais atrocidades inimagináveis ou indizíveis jamais se repitam. 


\section{Referências bibliográficas}

BELÉM LOPES, Dawisson; SALIBA, Aziz Tuffi. A doutrina da Responsabilidade ao Proteger (RwP). Disponível em: https://guiadefontes.msf.org.br/doutrina-da-responsabilidadeao-proteger-rwp/. Acesso em: 04 maio 2018.

CANÇADO TRINDADE, Antonio Augusto. A Humanização do Direito Internacional. Belo Horizonte: Del Rey, 2006.

DONNELLY, Jack. Human rights and human dignity: an analytic critique of non-Western conceptions of human rights. The American Political Science Review, vol. 76, No. 2 (Jun.), 1982, pp: 303-316.

HAILBRONNER, Michaela. Laws in conflict: The relationship between human rights and international humanitarian law under the African Charter on Human and Peoples Rights. African Human Rights Law Journal, 16, 2016, pp: 39-364.

ICTY-International Criminal Tribunal for the former Yugoslavia. The Prosecutor v. Dusko Tadic, Decision on the Defence Motion for Interlocutory Appeal on Jurisdiction, IT-941-A, 2 October 1995.

INTERNATIONAL COMITTEE OF THE RED CROSS. The Geneva Conventions of 12 Agu. 1949. Geneva: ICRC, 1949.

LANDSBERG, Chris. Multilateralismo e a ONU na política externa da África do Sul. Austral: Revista Brasileira de Estratégia e Relações Internacionais, vol.4, n.8, 2015,43-58. LUBELL, Noam. Challenges in applying human rights law to armed conflict. International Review of the Red Cross, vol. 87, N 860, 2005. pp: 737 - 754.

LUTZ, David. African Ubuntu Philosophy and Global Management. Journal of Business Ethics, 84, 2009, p. 313-328. 
MAZZUOLI, Valerio de Oliveira. Curso de Direito Internacional Público. - 4. ${ }^{\mathrm{a}}$ edição revista, atualizada e ampliada-. São Paulo: Editora Revista dos Tribunais, 2010.

SILVEIRA, Edson Damas. Direitos fundamentais indígenas, movimento socioambiental e a formatação do estado na modernidade. Veredas do Direito. Belo Horizonte, v.6, n. 12, pp. 25-56, jul/dez 2009. Disponível em: < http://www.domhelder.edu.br/revista/index.php/veredas/article/view/157/131> Acesso em: 15 maio 2018.

SOOSAIPILLAI, Keethaponcalan. North-South relations and human rights. Bandung: Journal of the Global South, 2:1, 2015.

WEBER, Max. A política como vocação. Brasília: Editora UnB, 2003. 


\title{
DOS RECENTES FLUXOS MIGRATÓRIOS NO BRASIL: DA DISCRIMINAÇÃO E DA INVISIBILIDADE SOCIAL
}

Valéria Silva Galdino Cardin Universidade Estadual de Maringá (UEM) e Centro Universitário de Maringá (Unicesumar) Tereza Rodrigues Vieira Universidade Paranaense (Unipar)

\begin{abstract}
Resumo
O presente estudo analisou, por meio da revisão bibliográfica, a questão dos fluxos migratórios no Brasil, direcionando a abordagem do tema a investigação da condição de vulnerabilidade e invisibilidade social dos refugiados, como nos casos dos sírios, dos bolivianos, dos venezuelanos e dos haitianos que adentram diariamente no país. Buscou examinar, ainda, a (in)existência de programa específico de políticas públicas em prol desses migrantes, os quais acabam por ter seus direitos violados e, em muitos casos, submetidos a todo tipo de violência, discriminação e estigmatização, levando-os à marginalização e, consequentemente, à uma situação de rua.
\end{abstract}

Palavras-chave: Discriminação, Fluxos migratórios, Invisibilidade social, Políticas públicas, Refugiados.

\section{Abstract/Resumen/Résumé}

The present study analyzed, through the bibliographical review, the issue of migratory flows in Brazil, directing the approach of the theme to investigate the vulnerability and social invisibility of refugees, as in the cases of Syrians, Bolivians, Venezuelans and Haitians who enter daily into the country. It also sought to examine the (in) existence of a specific program of public policies in favor of these migrants, who end up having their rights violated and, in many cases, subjected to all kinds of violence, discrimination and stigmatization, leading them to marginalization and, consequently, a street situation.

Keywords/Palabras-claves/Mots-clés: Refugees, Migratory flows, Discrimination, Social invisibility, Public policy. 


\section{Introdução}

Hodiernamente, muitos países têm enfrentado crises de origem econômica, cultural, religiosa, política, dentre outras, acarretando a intensificação nos fluxos migratórios em busca de melhores condições de vida ou, até mesmo, para a sobrevivência.

Em razão da constante globalização e dos conflitos que vêm ocorrendo, muitas famílias são obrigadas a deixarem suas casas e seu país de origem, potencializando os fluxos migratórios e o hibridismo social e cultural, em que estes indivíduos necessitam adaptar-se a um novo modo de vida, a uma nova identidade cultural.

Sabe-se que o refúgio, em regra, é um instituto de proteção de responsabilidade global. Por estar em uma condição de vulnerabilidade, o refugiado é considerado como uma minoria social, uma vez pode ser revestido por uma latente invisibilidade por parte da sociedade, enfrentando, não raramente, abusos e atrocidades, fato que vêm ganhado relevância no plano internacional.

No Brasil, desde 2012, houve um aumento do número de refugiados, não conseguindo suprir as necessidades básicas e as especificidades dessas pessoas, revelando inúmeros obstáculos para estas, como a barreiras de idioma, da cultura e da discriminação.

Em virtude disso, são submetidos a oportunidades que desrespeitam os acordos internacionais e, sobretudo, a dignidade da pessoa humana, como, por exemplo, os subempregos, os trabalhos análogos à escravidão e, inclusive, à situação de rua, dentre diversas outras explorações.

Deste modo, o trabalho, buscará demonstrar a real situação que muitos refugiados atualmente enfrentam no Brasil, dando enfoque à pobreza, à exploração, à violência e à situação de rua desse segmento, ressaltando, também, a importância da implementação de políticas públicas migratórias que lhes assegurem seus direitos.

Para tanto, a pesquisa em apreço utilizará como método de investigação o bibliográfico, que consiste na consulta de obras, artigos de periódicos, documentos eletrônicos, bem como da legislação pertinente que trata do tema.

\section{Do conceito de refugiado}

Refugiados são os indivíduos que, de maneira forçada, saem de seus países de origem em busca de proteção, de sobrevivência. Os motivos que os levam a cruzarem as fronteiras 
nacionais de seus países podem ser os mais variados, os quais acabam por violar direitos humanos, como, por exemplo, situações de violência, de perseguições políticas, de conflitos étnicos, de desigualdade socioeconômica, de LGBTfobia, de desastres naturais, dentre outros. (MOREIRA, 2014).

Nesse sentido, Letícia Mirelli Faleiro Silva Bueno (2018, p. 79) afirma que:

Para que um indivíduo seja considerado refugiado é necessário que estejam presentes dois requisitos os quais são interdependentes, a saber, a extraterritorialidade e fundado temor de perseguição por motivos de raça, religião, nacionalidade, grupo social ou opiniões políticas.

Logo, o conceito de refugiado se estende não somente às pessoas perseguidas em razão da cor, religião, sexo ou opinião política, mas, também, àqueles cujos países encontram-se em uma situação de violência generalizada e, consequente, violação dos direitos humanos (BARRETO, 2010, p. 16).

Essa definição foi ampliada pelo Protocolo de 67, oriunda da Convenção de 1951, o qual rompeu a limitação territorial e temporal, intensificando assim a quantidade de pessoas buscando proteção. Ocorre que, em virtude da ausência de um financiamento humanitário, não há como acolher um grupo numeroso de pessoas de maneira adequada. (BUENO, 2018, p. 80).

A preocupação com estas pessoas não é recente, sendo que há registros que remetem ao ano de 1921, por conta da queda do Império Otomano e da Revolução Russa, quanto à proteção de pessoas que se encontram em situações especiais de abandono e desamparo no país ao qual pertencem (PAMPLONA e PIOVESAN, 2015).

Ademais, observa-se que:

[...] a proteção dos refugiados, de forma coordenada, iniciou-se por meio das atividades da Liga das Nações. Isso se deu, primordialmente, em razão de acontecimentos que tiveram lugar pouco antes, durante e, em especial imediatamente após a primeira grande guerra (ANDRADE, 1996, p. 20).

A Liga das Nações foi criada em 1919, cujo objetivo era assegurar a paz no mundo, bem como lidar com questões internacionais relevantes (BUENO, 2018, p. 75), daí a necessidade do posicionamento acerca da situação dos refugiados.

Contudo, foi após a Segunda Guerra Mundial, com a dissolução da Liga das Nações e criação da ONU - Organização das Nações Unidas, bem como do Alto Comissariado das 
Nações Unidas para Refugiados (ACNUR), que a sua finalidade também se direcionou ao suporte na recepção e integração de refugiados.

Mesmo com o término da Segunda Guerra Mundial, hodiernamente ainda ocorrem inúmeros fatores que obrigam as pessoas a abandonarem suas casas, suas famílias e seus países, em busca de segurança, sendo o Brasil um dos destinos mais escolhidos por tais.

\section{Dos recentes fluxos migratórios}

O processo de imigração não é um fenômeno recente, isso porque, desde a pré-história há registros de povos nômades que realizaram grandes deslocamentos, a procura de caça, alimentos e pastagens, situação que perdurou até o domínio das técnicas agrícolas.

Antes mesmo do refúgio ser reconhecido como um instituto jurídico de proteção, ele já existia desde os tempos bíblicos, como se depreende da história da sagrada família que necessitou deixar suas terras e se refugiar no Egito a fim de se proteger de Herodes (BUENO, 2018, p. 74).

Assim, pode-se inferir que o ser humano jamais deixou de deslocar-se pelo mundo, tendo em vista que este fenômeno faz parte da própria construção da história da humanidade (CARDIN, SILVA, 2017, p. 13).

No entanto, foi a partir do ano de 2012 que houve um crescimento desproporcional em relação aos anos anteriores da população que se deslocou à força, cujo ápice ocorreu no ano de 2015, ou seja, um total de 65,3 milhões de pessoas deslocadas pelo mundo em razão de guerras e conflitos, representando 5,8 milhões a mais do que no ano de 2014, que totaliza 59,5 milhões de pessoas (ACNUR, 2015).

Contudo, no ano de 2016, os deslocamentos forçados alcançaram um número recorde a nível mundial, segundo o Relatório Tendencias Globales $^{1}$, atingindo no referido ano a marca de 65,6 milhões de pessoas, dos quais segundo aquele 22,5 milhões são refugiados, 40,3 milhões são deslocados internos e 2,8 milhões pleiteiam asilo. Acrescente-se que a cada minuto do ano de 2016 cerca de 20 (vinte) pessoas foram obrigadas a fugir de sua residência (ACNUR, 2016).

São inúmeros os fatores que levam as pessoas a migrarem, sendo o principal a violência e pode-se ser citado como exemplo, as perseguições e os conflitos armados nos países

\footnotetext{
${ }^{1}$ Relatório elaborado anualmente pelo Alto Comissariado das Nações Unidas para Refugiados (ACNUR).
} 
como a Síria, o Iraque, o Iêmen e a África Subsaariana ${ }^{2}$, além do Afeganistão, da Líbia e da Ucrânia (ACNUR, 2016a).

Ressalte-se que dos países mais afetados pelos deslocamentos forçados em 2016, está a Síria, com a maior população de deslocados à força (12 milhões de pessoas), logo após o Afeganistão (4,7 milhões de pessoas), seguido do Iraque (4,2 milhões de pessoas), do Sudão do Sul (3,3 milhões de pessoas) e do Sudão (2,9 milhões de pessoas) (ACNUR, 2016).

No final do ano de 2016, ocorreram 2,8 milhões de novos pedidos de asilo, ou seja, pessoas que procuram proteção internacional, mas cuja condição de refugiado ainda não havia sido reconhecida. Do ano de 2015 até o 2016 a Alemanha foi a maior receptora de novos pedidos de asilo, seguida dos Estados Unidos, e da Itália, figurando em quarto e quinto lugares a Turquia e a França (ACNUR, 2016a), respectivamente.

Embora os pedidos de asilo em sua ampla maioria sejam destinados aos países mais desenvolvidos, estes não são muito receptivos para acolherem os refugiados, conforme o relatório do Alto Comissariado das Nações Unidas para os Refugiados, uma vez que aproximadamente $84 \%$ dos refugiados encontram-se em regiões de desenvolvimento (ACNUR, 2016a).

Observa-se que dos dez países que mais acolheram refugiados no ano de 2016, apenas um integra a lista dos países mais desenvolvidos, como demostrado a seguir: a Turquia, por exemplo, foi o país que acolheu o maior número (cerca de 2,9 milhões de pessoas), seguido pelo Paquistão (1,4 milhões), Líbano (1 milhão), Irã (979.400), Uganda (940.800), Etiópia (791.600), Jordânia (685.200), Alemanha (669.500), República Democrática do Congo (452.000) e Quênia (451.100) (ACNUR, 2016a).

Ressalte-se que os conflitos têm se concentrado nas regiões mais pobres do mundo, sendo que os países acolhedores são os limítrofes, o que reflete a ausência de responsabilidade dos demais países quanto ao acolhimento dos refugiados, que ao longo da última década tem fechado suas fronteiras e limitado a entrada desses indivíduos (ACNUR, 2016a), mesmo diante da crise humanitária que tem se agravado.

Conforme apontam os relatórios Childrens on the run e Women on the run (ACNUR, 2015) elaborados em 2014 e 2015, respectivamente, pelo Alto Comissariado das Nações Unidas para os Refugiados (ACNUR), a região da América Central composta por El Salvador, Guatemala e Honduras é considerada um dos lugares mais perigosos do mundo (ACNUR, 2015a), em decorrência da violência epidêmica associada ao domínio de grupos criminosos

\footnotetext{
${ }^{2}$ Há conflitos regionais em Burundi, República Central Africana, República Democrática do Congo, Sudão do Sul e Sudão.
} 
armados e organizados. E aproximadamente 388.000 (trezentas e oitenta e oito mil) pessoas já deixaram a região no ano de 2016 (ACNUR, 2017), sendo a maioria composta por mulheres e crianças (ACNUR, 2015b).

Países como o Haiti, a Bolívia, a Colômbia e a Venezuela têm impulsionado a circulação de um significativo número de pessoas para a América do Sul, despontando o Brasil como um dos principais destinos.

Tais dados estatísticos demostram a real proporção do problema que envolve os refugiados e a comunidade internacional, uma vez que famílias inteiras, muitas delas com crianças pequenas, mulheres grávidas e até mesmo idosos (GOMES, 2015), se arriscam em viagens longas, em rotas na maioria das vezes não seguras e acabam em situação de extrema precariedade no país de destino.

\section{Dos fluxos migratórios no Brasil: da discriminação e da invisibilidade social}

O Brasil é um país marcado pelo histórico e constante processo de miscigenação entre diversificados povos. Os primeiros imigrantes foram os colonizadores, que ocuparam o território recém-descoberto para fins de exploração, em sua grande maioria provenientes de Portugal e da Espanha. Aliada a prática da exploração de matérias-primas, trouxeram expressiva quantidade de mão-de-obra escrava advinda do continente africano (FULGÊNCIO, 2014, p. 208).

Com a abolição da escravidão em 1.888, pela Lei Áurea, houve um incentivo a novos fluxos migratórios para suprir principalmente a demanda das atividades agrícolas. Entre o final do século XIX e o início do século XX, estima-se que o Brasil recebeu 4,4 milhões de pessoas de outras nacionalidades, a maior parte de origem portuguesa, espanhola, italiana, japonesa e alemã (WERMUTH, 2015, p. 4).

$\mathrm{O}$ começo do século XX foi marcado pela crise na indústria cafeeira, que levou à redução dos incentivos aos estrangeiros. Após a Primeira Guerra (1914-1918), porém, o fluxo migratório voltou a crescer, dessa vez impulsionado por trabalhadores poloneses, judeus e russos em busca de novas oportunidades de vida. (PATARRA, 2005, p. 28).

O período posterior à Segunda Guerra (1939-1945) foi destacado pela chegada de outro tipo de estrangeiro: os refugiados de países afetados pelos conflitos bélicos, como os chineses e judeus, que se deslocavam com a ajuda de organismos internacionais. A partir de 
1960, outros povos, como bolivianos e coreanos, passaram imigrar para o território brasileiro, mas o ritmo migratório já era inferior e diminuiu ainda mais nas décadas seguintes.

Atualmente, o Brasil retoma o status de país receptor de migrantes. Em 2009, haviam 870 mil migrantes regulares. Em 2012, esse número subiu para 939 mil de estrangeiros, podendo ser este montante muito superior, já que as entradas de incontáveis imigrantes irregulares são subnotificadas, isto é, sequer chega ao conhecimento do Poder Público. A irregularidade desses imigrantes é favorecida tendo em vista as diversas formas de adentrar no território brasileiro, em decorrência das extensas costas litorâneas e fronteiriças com Estados vizinhos (FARIA, 2015).

Dados de 2016 apontam que o número de imigrantes registrados pela Polícia Federal aumentou $160 \%$ em dez anos. Segundo dados da PF, 117.745 estrangeiros deram entrada no país em 2015 - um aumento de 2,6 vezes em relação a 2006, isto é, de 45.124 imigrantes (VELASCO; MANTOVANI, 2016).

Recentemente houve a intensificação da entrada massiva de venezuelanos, sobretudo de maneira irregular. O conflito político e a crise econômica, como a falta de insumos para a população e investimentos de iniciativa privada, provocaram uma forte onda migratória de venezuelanos para os países vizinhos da América Latina, principalmente ao Brasil.

$\mathrm{Na}$ Venezuela, o conflito político e a crise econômica são os principais motivadores para os deslocamentos transnacionais. De acordo com o ACNUR, entre janeiro e setembro de 2017, cerca de 48.500 venezuelanos solicitaram refúgio no mundo, quase o dobro do ano anterior (ACNUR, 2017).

De acordo com o Ministério da Justiça Brasileiro, do início da crise venezuelana em 2013 até julho de 2017, aproximadamente 30.000 venezuelanos adentraram no Brasil em situações migratórias diversas ou em situação irregular. Somente nos quatro primeiros meses de 2018 cerca de 20 mil venezuelanos ingressaram no Brasil pelo estado de Roraima, levando a governadora a ingressar com uma ação civil pública para suspender a entrada de venezuelanos. No entanto, esta decisão não foi acatada pelo Supremo Tribunal Federal (MINISTÉRIO DA JUSTIÇA, 2017).

A Venezuela, por exemplo, desde 2013 enfrenta uma crise, após a morte do então presidente Hugo Chávez, que durante seu governo visou promover melhorias nas condições de vida da população mais desfavorecida. Desde então, Nicolás Maduro, tentou aplicar ao país as mesmas políticas do presidente anterior. Contudo, houve uma modificação da situação econômica do país em razão da redução do preço do barril de petróleo, base da economia 
venezuelana. Diante disso, uma grave crise econômica assola o país, visto que faltam produtos básicos para a sobrevivência das pessoas (ENTENDA, 2018).

O fato de faltarem insumos para a população e investimentos de iniciativa privada, desencadeou outros problemas sociais, principalmente envolvendo oposições políticas, acusando o então presidente de ser um ditador. A situação caótica provocou uma forte onda migratória de venezuelanos para os países vizinhos da América Latina, principalmente o Brasil (BBC, 2017).

Outra etnia que representa grande parte das imigrações para o Brasil são os haitianos, os quais, após o abalo sísmico que destruiu boa parte do território haitiano em 2010 aliada a forte crise social e de segurança, intensificaram sua vinda ao país, representando aproximadamente 73.000 mil haitianos entre os anos de 2012 e 2016 (MINISTÉRIO DA JUSTIÇA, 2017).

Outro motivo que levou os haitianos virem para o Brasil se deu pelo fato de que desde 2004, haviam tropas da ONU naquele país, as quais eram comandadas pelo Brasil, cujo objetivo era inibir os conflitos internos e o alto índice de violência que o país enfrentava. (CHARLEAUX, 2018).

Parcela considerável também de imigrantes é de sírios, que, forçados pela guerra civil, são impulsionados a se deslocarem em busca de sobrevivência. Segundo dados do Ministério da Justiça brasileiro, desde o início do conflito na Síria, 3.772 nacionais desse país solicitaram refúgio no Brasil. Há cerca de dois anos, o CONARE publicou uma normativa facilitando a concessão de vistos a imigrantes sírios (MINISTÉRIO DA JUSTIÇA, 2017).

Há cerca de dois anos, o CONARE publicou uma normativa facilitando a concessão de vistos a imigrantes sírios, resultado da enorme projeção que o conflito ganhou na imprensa internacional, apesar da dificuldade que estes encontram para se deslocarem do seu país até o Brasil em decorrência da distância que é de aproximadamente dez mil quilômetros, restando ainda as dificuldades de conseguir asilo após a solicitação junto a polícia federal.

Em que pese existir inúmeros instrumentos jurídicos elaborados no âmbito internacional visando assegurar os direitos dos refugiados, observa-se que estes indivíduos representam uma minoria social.

O que faz com que refugiados sírios procurem o Brasil é a existência de familiares nesse país. Há um número de 3 milhões de brasileiros com ascendência síria devido a uma onda de imigração que ocorreu no início do século XX. (LACERDA, SILVA, NUNES, 2015, p. 112)

Em São Paulo, a maior parte desses refugiados encontra a ajuda quase sempre da própria comunidade síria que ali está estabelecida, que promove campanhas de doação nas 
mesquitas ou nas igrejas ortodoxas cristãs, visando ajudar seus conterrâneos (LACERDA, SILVA, NUNES, 2015, p. 109).

Enquanto que na Bolívia o deslocamento ocorre em decorrência da extrema pobreza, que faz com que os bolivianos venham para o Brasil em busca de melhores condições de vida. Acrescente-se que o acordo Brasil/Mercosul, facilitou a regularização dessas pessoas em decorrência destes países serem integrantes do mesmo bloco (VELASCO, MANTOVANI, 2016).

Em que pese a Bolívia ser signatária da Convenção de 1951 e do Protocolo de 67, que são instrumentos protetivos e tratam do conceito de refugiado, em 2013 aquela foi condenada pela Corte Interamericana de Direitos Humanos, por expulsar família peruana de seu país. (BUENO, 2018, p. 85).

Em 2013, foram 8.200 imigrantes bolivianos que ingressaram no Brasil pelo corredor Puerto Quijarro/Corumbá, em busca de uma vida melhor. Entretanto, a realidade significa o contrário, condições precárias de moradia, baixos salários e muitas horas em confecção de roupas, que consiste na violação dos direitos humanos (ARAÚJO, FILÁRTIGAS, CARVALHO, 2015, p. 140).

Contudo, muitos não possuem qualquer qualificação e não conseguem emprego e assim, acabam nas ruas, mendigando (CRISE, 2013). O mesmo tem ocorrido com os venezuelanos.

Assim, evidencia-se que apesar dos instrumentos jurídicos existentes na seara internacional que prezam pela proteção dos refugiados, é necessário que exista uma política interna de cooperação e respeito aos Direitos Humanos nos países signatários da referida convenção, qual seja, de 1961, bem como do Protocolo de 67.

As estatísticas não revelam o número real de refugiados porque muitos deles adentram nos países de forma irregular, situação que ocorreu na Turquia durante os anos de 2015-2016 e que está ocorrendo no Brasil pelos venezuelanos na fronteira com Roraima.

Visando solucionar o problema relacionado à migração irregular, foi pactuado que "a partir de 20 de março de 2016, todos os novos migrantes irregulares que chegam às ilhas gregas serão devolvidos à Turquia se não pedirem asilo ou se o seu pedido for rejeitado.” (CONSELHO, 2016).

No Brasil, não há nenhuma medida ainda que tenha sido cogitada, apenas a governadora de Roraima que se manifestou no sentido de fechar a fronteira diante do caos em que se encontra a cidade, com venezuelanos acampados em praças públicas. 
Hodiernamente, não há uma estatística com o número preciso de refugiados no território brasileiro. Em relação ao ano de 2014, há apenas uma estatística da ACNUR, que diz ter aumentado 7.289, o número destes, tendo 81 nacionalidades distintas. Os principais países de origem são: Síria, Colômbia, Angola e Congo, situação que se agravou com a entrada de bolivianos e venezuelanos. (ACNUR, 2014)

A maioria destes refugiados, escolhem cidades como São Paulo e Rio de Janeiro para reconstruírem suas vidas, sendo que nestas não há qualquer estrutura por parte do governo para recepcioná-los, ficando os mesmos sob os cuidados de ONGs e instituições religiosas.

Entretanto, o que se nota é que nem sempre estas instituições conseguem garantir o apoio e assegurar a sobrevivência digna a estas pessoas, o que intensifica a situação de vulnerabilidade em que se encontram.

Com isso, um grande número de pessoas, por não estarem devidamente assistidas, vão para as ruas, desta vez em um país estranho à sua nacionalidade, onde há barreiras como a do idioma e da estigmatização a serem transpostas, dificilmente possuem acesso aos direitos mais básicos de forma adequada, demonstrando-se necessária a criação de políticas públicas migratórias em harmonia com os princípios da atual Constituição.

\section{Da vulnerabilidade dos refugiados no Brasil}

Em que pese existir inúmeros instrumentos jurídicos elaborados no âmbito internacional, visando assegurar os direitos dos refugiados, dentre os quais pode-se citar a proteção aos direitos culturais, o direito à identidade, dentre outros, observa-se que estes indivíduos são considerados uma minoria social.

De acordo com Élida Séguin, minoria pode ser compreendida como um grupo de indivíduos com um número populacional inferior àquele predominante em determinado país $\mathrm{e}$ que possuem uma característica que os distingue dos outros (SÉGUIN, 2002, p. 09).

Nesse sentido, em que pese “[...] o conceito de minoria possa estar relacionado ao aspecto quantitativo, este está mais relacionado à questão de subordinação, seja na ordem socioeconômica, política ou cultural de um grupo dominante ou majoritário" (CARDIN, SILVA, 2016, p. 87).

Ainda que consiga sobreviver aos conflitos e perseguições em seu país de origem, bem como à travessia das fronteiras nacionais, ao chegarem em um novo país, sofrem discriminação. Consequentemente, encontram dificuldades na busca por empregos, moradia, estudo, e até 
mesmo no relacionamento interpessoal. Pode-se inferir que a estigmatização do refugiado o leva a marginalização, uma vez que há uma exclusão social em razão de seu modo de vida.

Pode-se inferir que a estigmatização do refugiado o leva a marginalização, uma vez que há uma exclusão social em razão de seu modo de vida. Nesse sentido, pode-se inferir que:

O refugiado tem sua liberdade e sua autodeterminação cerceada, bem como fica sujeito à degradação, já que de forma deturpada é visto como o inimigo não pertencente à determinada comunidade ou grupo (CARDIN, SILVA, 2016, p. 90).

Em virtude do desamparo, discriminação e da vulnerabilidade social por estarem em um local distinto do qual estão habituadas, estas pessoas podem acabar em situação de rua (GOFFMAN, 1988, p. 07).

A situação de rua pode ser entendida como a falta de habitação convencional regular de determinada pessoa, e sua consequente morada em vias ou logradouros públicos, sem abrigo, proteção ou condições mínimas de higiene, como também o seu recolhimento em unidades de acolhida para pernoite temporário ou morada provisória. ${ }^{3}$

Em pesquisa realizada pela Secretaria Municipal de Direitos Humanos e Cidadania de São Paulo, demonstrou-se que $71 \%$ do total de imigrantes em situação são de origem africana. Essas condições potencializam a vulnerabilidade social desse segmento, sobretudo ao que diz respeitos as questões relacionadas com a saúde, como a exposição a inúmeras doenças, incluindo o vício à drogadição (BOEHM, 2016).

Saliente-se que a condição de rua, não se trata apenas de um problema oriundo de países subdesenvolvidos. Isso porque, houve um aumento considerável de moradores de rua em países considerados de primeiro mundo ou desenvolvidos como: Alemanha, Inglaterra, Portugal, Bulgária, dentre outros (BOSEN, 2018).

Especificamente na Alemanha, em 2016, cerca de 860 mil pessoas não tinham moradia no país, sendo 440 mil eram refugiados que vivem em abrigos coletivos (NÚMERO, 2017). Este cenário evidencia a falta de uma gestão pública efetiva destes países considerados desenvolvidos, bem como a necessidade de políticas públicas voltadas para a inserção destas pessoas na sociedade local (MARQUES, SOUZA, 2018).

No que tange aos imigrantes venezuelanos, muitos se encontram em situação de rua, apesar da "operação acolhida" uma vez que esta não se mostrou suficiente em relação ao

\footnotetext{
${ }^{3}$ Cf. Decreto n ${ }^{\mathrm{o}} 7.053 / 2009$, art. $1^{\mathrm{o}}$, parágrafo único.
} 
número de imigrantes que cruzam as fronteiras todos os dias, que segundo os cálculos da polícia federal, chega a 800 imigrantes por dia, em busca de melhores condições de sobrevivência (MARQUES, SOUZA, 2018).

O governo de Roraima protocolou, no mês de abril de 2018, uma ação civil no STF com pedido de tutela provisória para que a fronteira do Brasil com a Venezuela fosse fechada por prazo determinado, impedindo a entrada de imigrantes no Estado. A ação pede ainda recursos adicionais para suprir os custos de saúde e educação com os imigrantes (MARQUES, SOUZA, 2018).

A ação do governo de Roraima associa a imigração em massa de venezuelanos ao aumento de violência e a precariedade da saúde pública no Estado, como por exemplo, o reaparecimento de doenças como sarampo e a tuberculose. Somente neste ano, segundo a polícia local, os venezuelanos teriam cometido 82 crimes, frente a 7 praticados em 2012 e 44 homicídios entre fevereiro e março, frente a 24 no mesmo período de 2017 (MARQUES, SOUZA, 2018).

O descontrole nas fronteiras segundo o governo de Roraima, tem oportunizado a prática de inúmeros crimes internacionais de drogas e armas com a participação de membros de facções criminosas tanto brasileiras, quanto venezuelanas (MARQUES, SOUZA, 2018).

Há relatos de instâncias internacionais que mesmo venezuelanos com ensino superior, residência temporária e com todos os documentos em dia, trabalham em troca de comida, em razão da necessidade, estando submetidos a casos de violência e assédio sexual no trabalho, violência física e verbal, condições de trabalho análogas à escravidão e evidencias de tráfíco humano, o que demonstra que o Brasil não está preparado para recepcionar os refugiados, tampouco garantir a dignidade dos mesmos (ESTADÃO, 2018).

Quanto aos sírios, a dificuldade com o idioma se torna um empecilho na busca por um emprego, mesmo aqueles que são portadores de um diploma de ensino superior, deixando-os em uma condição de miserabilidade, esperando muitas vezes por ajuda humanitária ou subemprego, até mesmo aqueles que possuem ensino médio ou superior (LOUREIRO, 2014).

Já em relação aos bolivianos, a situação é mais precária. Em decorrência da falta de documentação bem como de informação sobre seus direitos, acabam sendo explorados, principalmente como empregados domésticos e na indústria de confecções, vivendo em condições sub-humanas (LOUREIRO, 2014).

Os migrantes, portanto, já se encontram vulneráveis no momento de seu deslocamento e se não forem recepcionados pelo país acolhedor de forma digna continuarão tendo seus direitos fundamentais violados, desta vez em um país estranho ao seu, sofrendo todo tipo de 
adversidade. Faz-se necessário uma reformulação do serviço público voltado para este tipo de população, que seja mais inclusivo, considerando as particularidades deste grupo social.

\section{Das políticas públicas para inclusão social}

As precárias condições de vida dos imigrantes no Brasil são reflexos em grande parte da ausência de uma política migratória, fruto do Estatuto do Estrangeiro, oriundo do período ditatorial brasileiro que protegia apenas os interesses nacionais em detrimento de qualquer política migratória, sendo o estrangeiro visualizado como uma ameaça à ordem nacional e aos empregos dos brasileiros.

Em 24 de maio de 2017, foi sancionada a nova Lei. N. 13.445/2017, também denominada de Lei da Migração, que trata o migrante sob a ótica dos direitos humanos, proibindo qualquer forma de discriminação, além de prever a igualdade na regulamentação de documentos, no combate ao tráfico de pessoas, bem como na igualdade no tratamento laboral, assistência jurídica, trabalho, moradia, saúde, seguridade, dentre outros. Contudo, a referida Lei não prevê uma regulamentação específica acerca dos direitos laborais, acarretando, não raramente, em abusos e irregularidades cometidas pelos empregadores (OLIVEIRA, 2017, p. $175)$.

É extremamente difícil mensurar a quantidade de refugiados, daqueles que se encontram em situação de rua atualmente, uma vez que há pouco controle ou iniciativas do poder público em promover melhores condições de vida a estas pessoas.

Tendo em vista a vulnerabilidade social dos refugiados e no intuito de assegurar a proteção aos direitos humanos destes indivíduos, a sociedade internacional tem buscado estabelecer normas e princípios protetivos tanto em âmbito internacional quanto nos sistemas regionais (RESENDE, 2018, p. 112).

No âmbito internacional a proteção aos refugiados é regulamentada pela Convenção Relativa ao Estatuto dos Refugiados de 1951 e pelo seu Protocolo de 1967, o qual prevê que refugiados não podem ser expulsos ou devolvidos a situações onde suas vidas ou liberdade possam estar sob ameaça (RESENDE, 2018a, p. 115).

Em regra, os Estados devem ser os primeiros responsáveis pela efetivação da dignidade da pessoa humana e proteção destas pessoas. Entretanto, na prática observa-se que na maioria dos países ocorrem políticas migratórias discriminatórias que dificultam a entrada de refugiados em seus territórios ou, ainda, quando adentram no país, não há um apoio para que 
o mesmo se reestabeleça no país receptor, levando muitos à situação de rua (MENEZES, 2012, p. 38).

No intuito de estabelecer medidas para proteção dos direitos humanos dos refugiados, bem como de compartilhar esta responsabilidade em escala global, em 2016, ocorreu uma reunião na sede da ONU, que teve como resultado, a Declaração de Nova York sobre Refugiados e Migrantes, que estabeleceu a importância de garantir além da proteção, uma acolhida rápida e digna a estas pessoas (RESENDE, 2018a, p. 125).

Ademais, a declaração acima citada ressalta o compromisso dos Estados de criarem políticas públicas no intuito de viabilizar o acesso destas pessoas a direitos elementares como a saúde, a educação e a justiça, a fim de reduzir a quantidade de pessoas marginalizadas, bem como garantir a proteção aos direitos humanos. (RESENDE, 2018a, p. 125).

O refugiado já se encontra em uma situação de vulnerabilidade social no Brasil, que é um dos países que trata a situação dos refugiados de forma diferenciada, pois busca implementar programas de reassentamento, isto é, "quando um terceiro país acolhe refugiados que foram recusados pelo país acolhedor e que não podem retornar aos países de origem (MORAIS, BLUME, 2015).

Em 2010, o Brasil sediou uma reunião com países americanos cujo objetivo era tratar da proteção dos refugiados e apátridas no continente americano. Já em 2012, na cidade de Fortaleza, os países do Mercosul reuniram-se, sendo que do encontro, resultou a Declaração de Princípios do MERCOSUL sobre a proteção aos refugiados (BUENO 2018, p. 84).

No Brasil, não existe um programa específico de políticas públicas em prol dos migrantes. Contudo, é uma questão de solidariedade e justiça social assegurar a estes os direitos econômicos, sociais e culturais, em especial o direito à saúde, ao trabalho e à educação.

A Constituição Federal de 1988, em seu artigo 203, garante a prestação de assistência social a quem dela precisar, tendo como um de seus objetivos, a promoção da integração ao mercado de trabalho. Por sua vez, a Lei n. 9.474/97, também denominada como Estatuto dos Refugiados, nos artigos 43 e 44 destaca a simplificação das exigências na apresentação de documentos no país de origem, facilitação no reconhecimento de certificados e flexibilidade para o ingresso em instituições acadêmicas, uma vez que a situação vivenciada pelos refugiados, lhes é particularmente desfavorável (MILES, CARLET, 2015).

O Ministério do Trabalho e Emprego alterou a identificação da carteira de trabalho na emissão do documento para refugiados, eliminou o termo "refugiado" e passou a adotar o termo “estrangeiro) com base na Lei 9.474/97. Iniciativa importante no combate à discriminação e 
exploração que sentiam os refugiados ao buscarem trabalho ou emprego (MILES, CARLET, 2015).

Quanto ao direito à saúde destaca-se a criação do primeiro centro de referência para a saúde dos refugiados, instalado no hospital dos servidores no estado do Rio de Janeiro, com o objetivo de capacitar profissionais do sistema único de saúde, uma vez que estes ao chegarem ao país tem dificuldade de comunicação, traumas psicológicos, etc, o que requer maior sensibilidade na acolhida (MILES, CARLET, 2015).

O ACNUR tem parcerias com a Secretaria Especial de Políticas de Promoção da Igualdade Racial (SEPPIR), a Secretaria Especial de Políticas para Mulheres e com os ministérios da Saúde, Educação, Trabalho e Desenvolvimento Social para ministrar cursos de língua portuguesa, capacitação profissional e alocação em postos de trabalhos. Também oferece programas de microcréditos para refugiados que pretendem montar pequenos negócios. (MOREIRA, 2005, p. 68-9). O bolsa família, que se trata de um benefício originalmente destinado aos brasileiros, também tem sido oferecido para os refugiados que se enquadram nos requisitos do benefício.

Como medida paliativa e diante da verdadeira explosão do fluxo migratório venezuelano, no dia 29 de abril de 2018, no porto Demétrius, zona sul de Manaus, foi enviado um comboio de viaturas do exército brasileiro, para serem utilizadas na força tarefa logística humanitária da operação acolhida, desencadeada em março pelo Ministério da Defesa em Roraima em apoio a estas pessoas. No total, foram 15 viaturas entre carretas, vans e ambulâncias além de militares que irão para Boa Vista/Pacaraima no intuito de recepcionar e apoiar os imigrantes, por meio de medidas assistenciais, como distribuição de alimentos, melhoria nas condições de abrigos, e saúde. (G1, 2018).

Em que pese o interesse dos Estados em discutirem a situação dos refugiados, nota-se que ainda há a necessidade de ações concretas, bem como capacitação dos agentes públicos, objetivando a garantia de melhores condições de vida a este grupo de pessoas, uma vez que em virtude de preconceito e discriminação, muitos não conseguem se estabelecer no país receptor, o que gera uma situação de maior vulnerabilidade quando estes ficam em situação de rua.

\section{Conclusão}

Refugiados são pessoas que saem de seus países de origem em busca de proteção de maneira forçada. Os motivos são inúmeros, tais como: violência; perseguições políticas, 
conflitos étnicos, desigualdade socioeconômica, dentre outros, que ocasionam a violação dos Direitos Humanos.

Embora os pedidos de asilo em sua maioria sejam destinados aos países mais desenvolvidos, estes não são muito receptivos e os refugiados acabam sendo acolhidos em países em desenvolvimento.

A América do Sul, principalmente o Brasil, tem sido o destino de refugiados de países como o Haiti, a Bolívia, a Síria e a Venezuela.

O Brasil é um país que, ao longo da sua história, foi marcado pela miscigenação de diferentes povos. Contudo, este número de migrantes tem aumentado a cada dia tendo em vista a entrada massiva de venezuelanos, de haitianos, de sírios e bolivianos.

Muitos refugiados não possuem qualquer qualificação e não conseguem emprego e, assim, acabam nas ruas. Apesar dos instrumentos jurídicos internacionais que prezam pela proteção dos refugiados, é necessário que haja uma política interna de cooperação e respeito aos Direitos Humanos nos países signatários da Convenção de 1951, bem como do Protocolo de 1967.

No Brasil, não há qualquer estrutura por parte do governo para recepcioná-los, ficando os mesmos sob os cuidados de ONGs e instituições religiosas.

Há relatos de instâncias internacionais indicando que, mesmo os refugiados com ensino superior, trabalham em troca de comida no Brasil, sem falar em casos de violência e assédio sexual no trabalho, como a violência física e verbal, ou, ainda, submetidos às condições de trabalho análogas à escravidão, o que demonstra a vulnerabilidade em que se encontram àqueles.

Apesar da nova Lei de Migração ser um avanço aos direitos econômicos, sociais e culturais dos migrantes no Brasil, não há um programa específico de políticas públicas em prol dos migrantes. Mas temos algumas políticas públicas como o primeiro centro de referência para a saúde de refugiados no Rio de Janeiro, cursos de língua portuguesa, capacitação profissional, alocação em postos de trabalhos, programas de microcréditos para refugiados que pretendem montar pequenos negócios, que são parcerias do ACNUR com a Secretaria Especial de Políticas de Promoção da Igualdade Racial (SEPPIR), Secretaria Especial de Políticas para Mulheres e com os ministérios da Saúde, Educação, Trabalho e Emprego. A bolsa família também tem sido oferecida para os refugiados desde que se enquadram nos requisitos do benefício. Além de medidas assistenciais, como distribuição de alimentos, melhoria nas condições de abrigos e saúde. 
Apesar da previsão de inúmeros direitos e diretrizes para a efetivação de políticas na Lei de Migração, a partir de valores éticos, humanitários e de solidariedade social na garantia dos direitos fundamentais, respeito à dignidade e cidadania, ainda falta a devida concretização em prol de uma vida melhor para os refugiados. Faz-se necessário, portanto, por parte do poder público elaborar políticas públicas efetivas de inclusão e voltadas à geração de empregos, acesso à educação, à justiça, à saúde e aos demais direitos essenciais à vida digna dos refugiados sob pena de viverem da mesma forma que no seu país de origem.

\section{Referências bibliográficas}

8 PERGUNTAS para entender a crise na venezuela e a convocação da assembleia constituinte. BBC Brasil, 2017. Disponível em: $<$ http://www.bbc.com/portuguese/ internacional-39716719>. Acesso em: 24 abr. 2018.

\section{ALTO COMISSARIADO DAS NAÇÕES UNIDAS PARA REFUGIADOS (ACNUR).}

Tendencias Globales: desplazamiento forzado en 2016. 2016. Disponível em:

$<$ http://s3.amazonaws.com/unhcrsharedmedia/2017/2017-06-19-Global-Trends-

2016/2016_TendenciasGlobales-ESP-BAJA.pdf>. Acesso em: 24 jun. 2017.

. Women on the run. 2015. Disponível em: $<$ http://www.unhcr.org/publications/ operations/5630f24c6/women-run.html>. Acesso em: 01 jun. 2017.

. Infográfico: Crianças em Fuga, a solução do problema. 2017. Disponível em:

$<$ http://www.acnur.org/portugues/quem-ajudamos/criancas/criancas-em-fuga/ $>$. Acesso em: 01 jul. 2017.

ANDRADE, José Henrique Fischel de. Direito Internacional dos Refugiados: evolução histórica. Rio de Janeiro: Renovar, 1996.

ARAÚJO, Ana Paula Correia de; FILÁRTIGAS, Danilo Magno Espíndola; CARVALHO, Luciani Coimbra de. Bolivianos no Brasil: migração internacional pelo corredor fronteiriço Puerto Quijarro (BO)/Corumbá (MS). Revista Interações, Campo Grande, v. 16, n. 1, p. 131- 
141, jan./jun. 2015. Disponível em: <http://www.scielo.br/pdf/inter/v16n1/1518-7012-inter16-01-0131.pdf>. Acesso em: 02 maio 2018.

BARRETO, Luiz Paulo Teles Ferreira. A Lei Brasileira de Refúgio - Sua história. In: BARRETO, Luiz Paulo Teles Ferreira (Org.). Refúgio no Brasil: a proteção brasileira aos refugiados e seu impacto nas Américas. Brasília: ACNUR, 2010.

BOEHM, Camila. Migrantes são mais de $70 \%$ da população em situação de rua na capital paulista. Agência Brasil, 2016. Disponível em: <http://agenciabrasil.ebc.com.br/direitoshumanos/noticia/2016-04/migrantes-sao-mais-de-70-da-populacao-em-situacao-de-rua-nacapital>. Acesso em: 25 abr. 2018.

BOSEN, Ralf. Europa enfrenta aumento de moradores de rua. Disponível em: $<$ http://p.dw.com/p/2uhyd $>$. Acesso em: 25 abr. 2018.

BUENO, Letícia Mirelli Faleiro Silva. Proteção normativa dos refugiados: um escorço sobre o sistema global de proteção e a perspectiva do direito brasileiro. In: MAZZUOLI, Valério de Oliveira. Direitos Humanos das Minorias e Grupos Vulneráveis. Belo Horizonte: Arraes Editores, 2018.

CARDIN, Valéria Silva Galdino. SILVA, Flávia Francielle da. Dos direitos culturais e dos direitos humanos: da estigmatização do refugiado à construção do diálogo intercultural. In: Revista Brasileira de Direito Internacional. Curitiba, v. 2, n. 2, p. 78 - 99, Jul/Dez. 2016. Disponível em: <http://www.indexlaw.org/index.php/direitointernacional/article/view /1649/pdf>. Acesso em: 25 abr. 2018.

CARDIN, Valéria Silva Galdino. SILVA, Flávia Francielle da. Das mulheres refugiadas: a falta de iniciativas políticas voltadas para o genêro como fator de vulnerabilidade e invisibilidade social. In: FILHO, Benedito Cerezzo Pereira; BORGES. Maria Creusa De Araújo; CARDIN, Valéria Silva Galdino. Direito internacional dos direitos humanos I Florianópolis: CONPEDI, 2017.

CHARLEAUX, João Paulo. 3 diferenças entre as migrações haitiana e venezuelana no

Brasil. Disponível em: <https://www.nexojornal.com.br/expresso/2018/03/13/3- 
diferen $\% \mathrm{C} 3 \% \mathrm{~A} 7$ as-entre-as-migra $\% \mathrm{C} 3 \% \mathrm{~A} 7 \% \mathrm{C} 3 \% \mathrm{~B} 5$ es-haitiana-e-venezuelana-no-Brasil $>$. Acesso em: 26 abr. 2018.

CONSELHO EUROPEU. Declaração UE-Turquia, 18 de março de 2016. Disponível em: $<$ http://www.consilium.europa.eu/pt/policies/migratory-pressures/countries-origin-transit/euturkey-statement/>. Acesso em: 26 abr. 2018.

CRISE na Bolívia pode aumentar tensão social no Brasil. Disponível em: $<$ http://clicrbs. com.br/especial/sc/qualidade-de-vida-sc/19,0,870268,>. Acesso em: 25 abr. 2018.

ENTENDA a crise na Venezuela que provocou forte onda migratória ao Brasil. O Povo, 2018. Disponível em: <https://www.opovo.com.br/noticias/mundo/2018/03/entenda-a-crisena-venezuela-que-provocou-onda-migratoria-ao-brasil.html>. Acesso em: 23 abr. 2018.

\section{ESTADÃO. Imigrantes venezuelanos no Brasil são vítimas de exploração do trabalho.}

2018. Disponível em: $<$ http://internacional.estadao.com.br/noticias/geral,imigrantesvenezuelanos-no-brasil-sao-vitimas-de-exploracao-do-trabalho,70002218795>. Acesso em 02 maio 2018.

FARIA, Maria Rita Fontes. Migrações internacionais no plano multilateral: reflexões para a política externa brasileira. Brasília: FUNAG, 2015.

FULGÊNCIO, Rafael Figueiredo. O paradigma racista da política de imigração brasileira e os debates sobre a "Questão Chinesa" nos primeiros anos da República. Revista de Informação Legislativa, ano 51, n. 202, abr./jun. 2014. Disponível em: $<$ https://www2.senado.

leg.br/bdsf/bitstream/handle/id/503045/RIL202.pdf?sequence=8>. Acesso em: 03 maio 2018.

GOFFMAN, Erving. Estigma: notas sobre a manipulação da identidade deteriorada. Rio de Janeiro: LTC, 1988.

GOMES, Leonardo. Os refugiados e o desafio da solidariedade internacional. Pano de Fundo, n. 05, 2015. Disponível em: <http://repositorio.asces.edu.br/bitstream/123456789/ 751/1/EDICAO-5--ANO-1-22-25-ok.pdf>. Acesso em: 16 mar.2018. 
LACERDA, Jan Marcel de A. F.; SILVA, Amanda Arruda de S.; NUNES, Rayanne Vieira G. O caso dos refugiados sírios no brasil e a política internacional contemporânea. Revista de Estudos Internacionais (REI), v. 6, n. 2, 2015. Disponível em: <http://www.revistadees tudosinternacionais.com/uepb/index.php/rei/article/view/209/pdf>. Acesso em: 02 maio 2018.

LAGO, Igor Paes Leme Lellis do. Muitas Visões: Os refugiados sírios no Brasil. Revista Diáspora, ano 1, n. 01, dez. 2015. Disponível em: <http://www.revistadiaspora.org/wpcontent/uploads/2015/12/Revista-Di\%C3\%A1spora-001.pdf>. Acesso em: 24 abr. 2018

LOUREIRO, Gabriela. Como vivem os refugiados sírios no Brasil. Exame, 2014. Disponível em:<https://exame.abril.com.br/brasil/como-vivem-os-refugiados-sirios-no-brasil/>. Acesso em: 02 maio 2018.

MARQUES, Marcelo; SOUZA, André de. Governo de Roraima pede ao STF para fechar fronteira com a Venezuela e impedir entrada de imigrantes. O Globo, 2018. Disponível em: < https://oglobo.globo.com/brasil/governo-de-roraima-pede-ao-stf-para-fechar-fronteira-comvenezuela-impedir-entrada-de-imigrantes-22587813>. Acesso em: 02 maio 2018.

MENEZES, Marilda Aparecida de. "Migrações e mobilidades: repensando teorias, tipologias e conceitos". In: TEIXEIRA, Paulo Eduardo; BRAGA, Antonio Mendes da Costa; BAENINGER, Rosana (Orgs.). Migrações: implicações passadas, presentes e futuras. Marília: Cultura Acadêmica, 2012.

MILES, Rosita. CARLET, Flávia. Refugiados e Políticas Públicas: pela solidariedade, contra a exploração. Disponível em: <http://www.migrante.org.br/migrante/index.php/refugiadosas2/154-refugiados-e-politicas-publicas-pela-solidariedade-contra-a-exploracao $>$. Acesso em: 02 maio 2018

\section{MINISTÉRIO DA JUSTIÇA. Mais de 400 mil estrangeiros vieram para o Brasil nos}

últimos três anos. 2014. Disponível em: <http://justica.gov.br/news/mais-de-400-milestrangeiros-vieram-para-o-brasil-nos-ultimos-tres-anos>. Acesso em: 02 maio 2018. 
MORAIS, Renata Cabrera de; BLUME, Bruno André. O Brasil e a crise de refugiados.

Politize!, 2015. Disponível em: <http://www.politize.com.br/o-brasil-e-a-crise-derefugiados/>. Acesso em: 24 abr. 2018.

MOREIRA, Julia Bertino. Refugiados no Brasil: reflexões acerca do processo de integração local. REMHU - Rev. Interdiscip. Mobil. Hum., Brasília, Ano XXII, n. 43, p. 85-98, jul./dez. 2014. Disponível em: <http://www.scielo.br/pdf/remhu/v22n43/v22n43a06.pdf>. Acesso em: 23 abr. 2018.

MOREIRA, Julia Bertino. A problemática dos refugiados na América Latina e no Brasil. Cadernos PROLAM/USP, São Paulo, v. 2, p. 57-76, 2005.

NÚMERO de pessoas sem moradia na Alemanha aumenta 150\%. 2017. Disponível em: $<$ http://p.dw.com/p/2nc6w>. Acesso em: 25 abr. 2018.

OLIVEIRA, Antônio Tadeu Ribeiro de. Nova lei brasileira de migração: avanços, desafios e ameaças. In: Rev. bras. estud. popul., São Paulo, v. 34, n. 1, p. 171-179, abr. 2017. Disponível em: $<$ http://www.scielo.br/scielo.php?script=sci_arttext\&pid=S010230982017000100171\&lng=en\&nrm=iso $>$. Acesso em: 02 maio 2018.

PAMPLONA, Danielle Anne; PIOVESAN, Flávia. O Instituto do Refúgio no Brasil: práticas recentes. Revista de Direitos Fundamentais e Democracia, v. 17, n. 17, 2015. Disponível em: <http://revistaeletronicardfd.unibrasil.com.br/index.php/rdfd/article/view/629>. Acesso em: 23 abr. 2018.

PATARRA, Neide Lopes. Migrações internacionais de e para o brasil contemporâneo: volumes, fluxos, significados e políticas. São Paulo em perspectiva, v. 19, n. 3, p. 23-33, jul./set. 2005. Disponível em: <http://www.scielo.br/pdf/spp/v19n3/v19n3a02.pdf >. Acesso em: 02 maio 2018.

RESENDE, Julieth Laís do Carmo Matosinhos. Análise da Declaração de Nova York sobre Refugiados e Migrantes. In: MAZZUOLI, Valério de Oliveira (Org.). Direitos Humanos das Minorias e Grupos Vulneráveis. Belo Horizonte: Arraes, 2018. 
SÉGUIN, Elida. Minorias e grupos vulneráveis: uma abordagem jurídica. Rio de Janeiro: Forense, 2002.

SILVA, Sidney Antonio da. Bolivianos em São Paulo: entre o sonho e a realidade. Estudos Avançados, São Paulo, v. 20, n. 57, p. 157-170, ago. 2006. Disponível em:

$<\mathrm{http}$ ://www.scielo.br/scielo.php?script=sci_arttext\&pid=S0103-

40142006000200012\&lng=en\&nrm=iso>. Acesso em: 25 abr. 2018

VELASCO, Clara. MANTOVANI, Flávio. m 10 anos, número de imigrantes aumenta 160\% no Brasil, diz PF. In: G1, 2016. Disponível em: <http://g1.globo.com/mundo/ noticia/2016/06/em-10-anos-numero-de-imigrantes-aumenta-160-no-brasil-diz-pf.html>. Acesso em: 25 abr. 2018.

VIEIRA DE PAULA, Bruna. O princípio do non-refoulement, sua natureza jus cogens e a proteção internacional dos refugiados. Revista do Instituto Brasileiro de Direitos

Humanos, n. 7, p. 51-68, jul. 2016. Disponível em: <http://revista.ibdh.org.br/ index.php/ibdh/article/view/94>. Acesso em: 26 abr. 2018.

WERMUTH, Maiquel Ângelo Dezordi. A (bio)política migratória brasileira entre utilitarismo e repressivismo: sobre a necessidade de suplantação da ideia de "segurança nacional" em busca da comunidade que vem. Derecho y Cambio Social, ano 12, n. 39, 2015. Disponível em: $<$ https://dialnet.unirioja.es/servlet/articulo? codigo=5460675>. Acesso em: 02 maio 2018. 


\title{
ESTADO DEMOCRÁTICO DE DIREITO E A HUMANIZAÇÃO E ACOLHIMENTO À PESSOA IDOSA COMO RESPEITO À DIGNIDADE HUMANA E À CIDADANIA: CONSIDERAÇÕES DE CARÁTER NORMATIVO E CULTURAIS
}

\author{
Cláudia Mansani Queda De Toledo \\ Instituição Toledo de Ensino de Bauru - ITE
}

Flávia Piva Almeida Leite

Universidade Estadual "Júlio de Mesquita Filho" - UNESP

\begin{abstract}
Resumo
O trabalho objetiva a abordagem das medidas proteção, humanização e o acolhimento à pessoa idosa, cuja análise se dá por meio do raciocínio dedutivo, ao trazer os dados históricos da evolução dos direitos humanos para justificar a inserção constitucional da proteção ao idoso com vistas ao seu integral atendimento e assegurar o direito de envelhecer com dignidade, em busca do efetivo exercício da cidadania. A relevância social do estudo, encontra assente porque busca evidenciar reflexões os institutos do envelhecimento, da dignidade e da humanização ao idoso.
\end{abstract}

Palavras-chave: Idoso, Direitos Humanos, Proteção, Dignidade Humana, Cidadania.

\section{Abstract/Resumen/Résumé}

The objective of this study is to approach the protection, humanization and reception of the elderly, whose analysis is based on deductive reasoning, by bringing historical data on the evolution of human rights to justify the constitutional insertion of protection for the elderly with a view to their integral care and ensure the right to grow old with dignity, in search of the effective exercise of citizenship. The social relevance of the study is based on the fact that the institutes of aging, dignity and humanization of the elderly seek to reflect reflections.

Keywords/Palabras-claves/Mots-clés: Elderly, Human Rights, Protection, Human dignity, Citizenship. 


\section{Introdução}

A pessoa idosa, assim como toda e qualquer pessoa em outra etapa da vida, possui os mesmos direitos e garantias atinentes a cidadania, com especial e integral proteção com vistas às suas necessidades especiais, tal como previstas no artigo $2^{\circ}$ do Estatuto do Idoso, do qual se extraem os princípios da igualdade e da dignidade corolários do Estado Democrático de Direito.

A população idosa, nas últimas décadas, aumentou, tendo em vista a expansão dos números que demonstram o crescimento considerável da expectativa de vida das pessoas, de 75,5 para 75,8, valores que em números aparentam ser pequenos, mas que nos últimos 70 anos avançou para mais de 30 anos, o que tornou este segmento humano ainda mais representativo quanto aos critérios quantitativos, sem ainda se considerar a questão qualitativa dos necessários cuidados. (IBGE, 2018)

O objeto deste estudo identifica como necessária a análise destas informações em razão da forma como o Estado e a sociedade vêm tratando o idoso, vez que o problema de proteção ao idoso no Brasil, prima facie, parece se refletir como projeção do próprio déficit cultural de seu povo, e não na ausência de normativa específica nesse sentido, cuja afirmação se pretende melhor compreender nestetrabalho.

Não obstante ao fato de que a República brasileira, mesmo intitulada como um Estado Democrático de Direito, a partir da CF88 ainda enfrentar problemas na efetivação desta espécie de tutela, na medida em que se encontra eivada de déficits quanto ao exercício da cidadania, a refletir a ausência de atribuição de valor aos idosos como membros dasociedade.

No Brasil, a preocupação com o idoso se dá pelo reconhecimento no ordenamento jurídico por meio da proteção de seus direitos advindos das previsões constitucionais, das normas infraconstitucionais, mas se ressente de proteção no respeito à estas normativa tanto no âmbito privado como na seara pública quanto ao reconhecimento da vulnerabilidade destas pessoas e na forma como devem ser tratados.

A proteção mencionada motiva-se por diversas dimensões: em primeiro lugar, porque os idosos são igualmente seres humanos e, portanto, titulares de direitos e de dedicação de respeito por toda a formação estatal; em segundo lugar, em razão das suas necessidades peculiares decorrentes da idade; e, por fim, porque são pessoas que muito contribuíram, e ainda podem somar para a construção de uma sociedade justa e solidária, que atinja a busca pela cidadania. De modo que o idoso é sujeito dedireitos.

Aduz Silvio Romero Beltrão (2005, p. 19) que o idoso é pessoa natural e deveser o fim último da norma jurídica, o que se coaduna com o conceito kantiano de dignidade humana, 
segundo o qual o ser humano é um fim em si mesmo, refutando o tratamento do mesmo como um instrumento que, na verdade foi útil à sociedade e ao qual não se reconhece mais utilidade ou um caráter de instrumentalidade social.

O ordenamento jurídico brasileiro traz em si uma gama de paradigmas constitucionais e normas infraconstitucionais que regulam e protegem os direitos fundamentais da pessoa idosa e que se consolidaram como fruto de uma evolução histórica assim como todos os demais direitos fundamentais.

Ao lado deste, alguns marcos históricos foram evidentes nessa trajetória. No desenho do tempo, cabe recordar que com o final da Segunda Grande Guerra Mundial deu-se o início da internacionalização dos direitos humanos, que nascem comorespostas às atrocidades e às monstruosas violações cometidas pelo nazismo da era de Hitler. A partir de então, a luta pela conscientização material de um mínimo de direitos relacionados ao homem transpassa o campo reservado de um único Estado, e passa a ser encarado como um direito de domínio de toda acomunidade.

O Brasil não ficou alheio no que se refere ao sistema internacional de proteção aos direitos humanos. Com o advento da CF88, clausulou-se a abertura constitucional para o ingresso em nosso ordenamento de uma ampliação permanente dos direitos fundamentais, com abertura material de composição constitucional, inscrita no artigo $5^{\circ}, \S 2^{\circ}$ da CF88.

Dentro desse contexto, um avanço extraordinário na consolidação dos direitos e garantias fundamentais, em especial aqueles protetivos à vulnerabilidade, como mecanismos de proteção justificada e necessária à recomposição da natural desigualdade, quer decorrente de um longo processo de exclusão, quer decorrente de etnia, sexo, religião e idade, como no caso dos idosos.

Além das normas voltadas a uma proteção genérica a todas as pessoas, a Constituição Federal reconheceu a necessidade de uma descrição específica de proteção ao idoso, enquanto categoria diferenciada. Para tal efetivação, o Estado Democrático de Direito avançou e, a exemplo do que realizou em relação à criança e ao adolescente, aos índios, ao meio ambiente, assegurou, nos artigos 203, 229 e 230 uma proteção especial àvelhice.

Referidas normas são de cunho protetivo e dirigente, e embasam a atuação do legislador infraconstitucional e do poder público para a implementação das políticas públicas. Destaca-se desde o dever que os filhos maiores têm de ajudar e amparar ospais na velhice, na carência ou na enfermidade e, o dever da própria família, da sociedade e do Estado de amparar as pessoas idosas e assegurar a sua participação na comunidade, defender a sua dignidade e o seu bem-estar, a garantir-lhes o direito à vida, bem como, a existência condiga nesta fase etária 
avançada, com o consequente envelhecimento sadio e digno.

Com estas considerações iniciais o presente trabalho tem por objetivo a abordagem das medidas específicas de proteção e humanização e acolhimento à pessoa idosa, cuja análise se dá por meio do raciocínio dedutivo, ao trazer os dados históricos da evolução dos direitos humanos para justificar a inserção constitucional da proteção ao idoso com vistas ao seu integral atendimento como mister de todos os componentes da sociedade na busca de uma cidadania plena do idosovulnerável.

\section{Breve evolução histórica dos direitos do idoso}

A evolução histórica é item de abordagem sempre necessária quando se pretende enfrentar qualquer tema aderente à fundamentalidade de direitos, na medida em que os passos de reconhecimento de direitos humanos se configuram sempre como conquistas históricas. Assim, para introduzir o tema, se aborda acenos históricos no direito internacional, porém, sem o objetivo de esgotamento do tema, missão que exigiria um artigo ou pesquisa dedicados unicamente a este tema.

Sobre o tratamento do assunto no âmbito internacional pode-se afirmar que a civilização oriental, especialmente na China, desde a Antiguidade até os dias atuais o idoso sempre mereceu uma posição privilegiada. Para o filósofo Confúcio (551-479 a.C.), a base era a família, assim, acreditava que a autoridade da velhice é justificada pela aquisição da sabedoria. Os filhos mais jovens deviam obediência, respeito e amor para com seus pais. Para Confúcio não havia nada no mundo tão grande como o ser humano; e, no ser humano, nada é maior que a piedade filial.

Na civilização ocidental, no ano 2.500 a.C, a imagem obsessiva do corpo humano belo e perfeito tornou-se evidente desde os tempos mais antigos e, conforme nos narra Simone de Beauvoir em texto que descreve um trecho de sua primeira obra que se referiu à velhice, que foi elaborada no Egito por Ptah-Hotep, filósofo e poeta que nos mostra a face cruel do processo de envelhecimento, ao afirmarque:

Quão penoso é o fím do ancião! Vai dia a dia enfraquecendo: a visão baixa, seusouvidos se tornam surdos, o nariz se obstrui e nada mais pode cheirar, a boca se torna silenciosa e já não fala. Suas faculdades intelectuais se reduzem e torna-se impossível recordar o que foi ontem. Doem-lhe todos os ossos. A ocupação a que outrora se entregara com prazer, só a realiza agora com dificuldade e desaparece o sentido do gosto. A velhice é a pior desgraça que pode acontecer a um homem (BEAUVOIR 1990,p.114). 
Ao lado do que contemporaneamente registra Beauvoir demonstrando a fragilidade do idoso, temos que na Idade Antiga, época em que tinham como objetivo principal a conquista territorial, só se prestigiavam aqueles homens fisicamente perfeitos, pois desta forma eram necessários e úteis para fazer parte de seus exércitos. Em Atenas, era corriqueiro os homens exortarem seus corpos nus e, o ato de exibir-se simbolizava com frequência um povo autoconfiante e totalmente à vontade. Tanto que para Péricles, a "cidade, em grego - polis, significava o espaço onde as pessoas alcançavam a mais alta expressão da unidade. (SENNET, 2008, pp.44-45)

Em Roma, a imagem obsessiva do corpo ideal também teve seu lugar e tempo na exclusão dos idosos na sociedade, bem como na construção do espaço urbano. "O imperador precisava que seu poder fosse evidenciado em monumentos e obras públicas. O governo não existia sem a pedra." (SENNETT, 2008, p. 93). Assim, a influência do corpo humano belo e perfeito tornou-se evidente na forma urbana dessa época, sendo a velhice, tratada e vista, de modo geral, com desprezo e com certa crueldade.

Ao escrever a República, Platão mostra-nos passagens onde Sócrates faz referências ao envelhecimento, como a ideia de que para os seres humanos prudentes e bem preparados, a velhice não constitui peso algum. Para tanto, Simone de Beauvoir transcreve um diálogo travado entre Sócrates e Céfalo sobre a velhice:

Céfalo convidou Sócrates para visitá-lo, desculpando-se por não ir procurá-lo, pelo fato de estar velho e ser difícil sair de casa. Queria conversar com o amigo, pois para Céfalo, quanto mais amortecidos ficam os prazeres do corpo, mais crescem o deleite e o prazer da conversação. Sócrates aceitou o convite, respondendo que lhe agrada muito conversar com pessoas de mais idade, que já tinham percorrido um caminho que ele teria que percorrer. Assim, deu-se oinício da conversa, quando Sócrates perguntou a Céfalo, como ele, já velho, sentia-se ao atingir a fase que os poetas chamavam de o limiar da velhice. Céfalo respondeu que muito bem, pois a triste cantilena, evocada por muitos, responsabilizando a velhice por todos os males, para ele era decorrente da própria vida e não da idade avançada. (BEAUVOIR,1990, p.135).

Nesse trecho percebe-se que um processo de envelhecimento tranquilo e saudável depende de uma juventude traçada da mesma forma e, não necessariamente da idadeavançada.

Em relação ao envelhecimento, Aristóteles achava que uma boa velhice era aquela em que o ser humano não apresentasse enfermidades. Na Ética, onde se concentram seus escritos mais famosos, nos ensina que o ser humano progride somente até os 50 anos. Essa concepção distorcida de velhice fazia-o ver os idosos como pessoas diminuídas, indignas de confiança e por isso precisavam ser afastadas do poder, não devendo exercer cargos de importância política 
(CRESCENZO, 1988).

No primeiro século antes da Era Cristã, Marco Túlio Cícero (103-43 a.C.), o grande filósofo romano, político, jurista e orador, demonstrou-se uma figura exponencial nos estudos sobre a velhice. Para esse filósofo, a arte de envelhecer está em descobrir o prazer que todas as idades proporcionam, pois todas têm as suas virtudes (CÍCERO,2001).

Assim, como vimos o envelhecimento não é um fenômeno novo. Afinal, pela lógica natural da existência, os homens nascem, crescem, amadurecem, vivem e morrem. "Entretanto, essas fases da vida não eram, até a consolidação domodelo capitalista, objeto de saberes. Sobre a velhice não incidia nenhum valor, nenhum discurso, nenhum saber, nenhuma preocupação. Não era tema de relevância" (RAMOS, 2014, p. 23).

A partir do século XIX, na medida em que o processo de industrialização avança, há a exigência de mão de obra mais qualificada, a qual requeria tempo e gastos para sua preparação. Dentro desse contexto, passa a ser conveniente queos trabalhadores também vivessem mais para recompensar os recursos gastos com a sua capacitação. Aliado a esse fator, em virtude do aumento da expectativa de vida, reflexo do desenvolvimento e progresso das sociedades, o idoso passa a usufruir de melhores condições psicológicas e físicas. Assim, como resultado dessa sociedade cada vez mais complexa, que exigia uma nova postura diante da existência, especialmente de sua duração como condição essencial para a própria sobrevivência do sistema em fase de afirmação, "a velhice passou a se apresentar como fenômeno não somente biológico, mas fundamentalmente social" (RAMOS, 2014, p.23).

A questão do envelhecimento não se tornou uma questão social relevante apenas pela quantidade de idosos cada vez maiores em nossas sociedades, mas, especialmente, pelo motivo dessas pessoas e demais grupos vulneráveis, tais como pessoas com deficiência, crianças e adolescentes dentre outros e, demais grupos sociais a eles solidários terem se mobilizado no sentido de exigir que direitos essenciais lhes fossem reconhecidos.

Na seara internacional de proteção dos direitos humanos, esta regulamentação está solidificada na Declaração Universal dos Direitos Humanos, que prevê, em seu artigo II, item 1, de forma genérica nestes termos:

Artigo II. 1 - Todo ser humano tem capacidade para gozar os direitos e as liberdades estabelecidos nesta Declaração, sem distinção de qualquer espécie, seja de raça, cor, sexo, idioma, religião, opinião política ou de outra natureza, origem nacional ou social, riqueza, nascimento, ou qualquer outra condição. 
Entretanto, apesar de tal documento internacional ter sido aprovado em Assembleia Geral da ONU, em 10 de dezembro de 1948, anunciando a necessidade neste jus cogens daadoção de formas mais específicas, apenas 12 (doze) países trazem em seus textos constitucionais atuais as garantias e proteções às pessoas idosas, uma vez que, "na atualidade, 12 (doze) constituições modernas trazem em seus textos normas de proteção à velhice" (RAMOS, 1999, p. 152), sendo os seguintes países: Brasil, China, Cuba, Espanha, GuinéBissau, Itália, México, Peru, Portugal, Suíça, Uruguai e Venezuela.

No ano de 1991, em 16 de dezembro, a ONU elaborou os Princípios das Nações Unidas para o Idoso, aprovada na Resolução 46/91, que ressalta a importância desse grupo de pessoas na sociedade, com participação ativa na formulação e implementação de políticas públicas, com objetivo de promover o seu bem-estar, por meio de serviços voluntários à comunidade e atuação em movimentos e associações da sociedade civil, o que se verifica pelos grupos de terceira idade que se organizam em associações com objetivo de conquistar o espaço que lhes têm sido negadas.

Em 2002, foi aprovado o Plano de Ação Internacional para o envelhecimento, em Madrid,que

\begin{abstract}
coloca muito claramente o 'aumento da expectativa de vida como uma das maiores conquistas da humanidade'. Assim, a longevidade é um processo contraditório com a modernidade, pois se aumenta a longevidade e se coloca a questão da discussão da improdutividade e da finitude da vida, ou seja, a preocupação em se viver muito com qualidade e com a preocupação de nãose viver sempre" (FALEIROS, 2008, p.65).
\end{abstract}

Supracitado sociólogo, Vicente Faleiros (2008, p. 66) discorre acerca dos desafios nas políticas públicas, nas famílias e na própria sociedade.

Essa atuação das pessoas interessadas se apresenta como efetivação da dignidade deste grupo vulnerável. E, para atingi-la de forma plena, cabe à sociedade cumprir seudever de solidariedade e reconhecer a importância dos idosos na sociedade. Por esta razão, deve-se difundir os direitos e garantias conferidos aos idosos, pois, somente assim é que se garante efetivamente- a vida em suaplenitude.

Observe-se, no entanto, que os acenos de proteção internacional ainda não se transmudaram em tratados devidamente ratificados, muito embora, historicamente, tal seja uma consequência natural.

No ordenamento jurídico brasileiro a dignidade da pessoa um princípio inarredável reconhecido como fundamento de validade dos sistemas constitucionais, coerentemente 
consagra-se nesse estado como um dos alicerces fundamentais da sociedade brasileira, conforme o expresso na Constituição da República Federativa do Brasil (art. ${ }^{\circ}$, inciso III).

No texto constitucional de 1988 estabeleceu-se os princípios e objetivos de o Estado Brasileiro ser um Estado Democrático, ou seja, um Estado em que há o direito a ter direitos e, na proteção aos idosos, assim como a proteção aos grupos vulneráveis, a proibição de quaisquer formas de discriminação, incluída a discriminação por idade, conforme inciso IV do artigo $3^{\circ}$, bem como a prevalência dos direitos humanos constante no inciso II do artigo $4^{\circ}$.

Destaca-se que a Carta Magna de 1988 é o primeiro texto constitucional que expressamente protege os direitos inerentes à pessoa idosa, pois "a Constituição Imperial (1824) e a da República de 1891 nada dispuseram, enquanto a de 1934, ao introduzir capítulo relacionado à 'Ordem Econômica e Social', determinou à legislação trabalhista a garantia de assistência previdenciária ao empregado, inclusive em sua velhice (RODRIGUES, 2012, p. 441 apud RAMOS, 1999, p.152).

A Constituição Federal de 1988 inaugura uma nova fisionomia ao Estado, vez que não somente o consagrou como democrático, como também ressaltou o seu caráter essencialmente social, ao fundá-lo em valores como a dignidade humana e cidadania, que irradiaram seus efeitos sobre todo o ordenamento. Esse novo modelo de Estado tem a tarefa fundamental de superar as desigualdades, não apenas econômicas e sociais, mas também as desigualdades ocasionadas em razão de raça, cor, sexo, condições físicas e de idade. Ao destacar essas desigualdades, a Constituição inseriu a proteção constitucional às pessoas idosas. Assegurou-a de forma direta à velhice em seus artigos 229 e230.

O artigo 229 da CF dispõe acerca do dever dos filhos maiores de amparar aospais na velhice e o caput do artigo 230 do texto constitucional estatui que "a família, a sociedade e o Estado têm o dever de amparar as pessoas idosas, assegurando sua participação na comunidade, defendendo sua dignidade e bem-estar e garantindo-lhes o direito à vida.”

Desta forma, estabeleceu "uma relação jurídica obrigacional na qual figuram, no polo passivo, com deveres jurídicos, a família, a sociedade e o Estado (Poder Público), e, como sujeito ativo, titular dos direitos, o idoso (RODRIGUES, 2012, p.439).

Por meio dos paradigmas constitucionais e das normas legais infraconstitucionais, verifica-se a proteção da pessoa idosa, com expressa garantia de seus direitos fundamentais.

No plano infraconstitucional foi promulgada a Lei $n^{\circ} 8.842 / 1994$ que dispõe sobre a Política Nacional do Idoso, com objetivo de assegurar os direitos sociais ao idoso, criando condições para promover sua autonomia, participação efetiva e integração na sociedade. $\mathrm{Na}$ sequência, é instituído o Decreto $\mathrm{n}^{\circ} 4.227 / 2002$, que cria o Conselho Nacional dos Direitos dos 
Idosos, órgão vinculado ao Ministério da Justiça, com competência para supervisionar e avaliar a Política Nacional do Idoso, entre outras funções relacionadas àmatéria.

Anterior a legislação de 1994, em 7 de dezembro de 1993, foi promulgada a Lei Federal $n^{\circ} 8.742$, denominada Lei Orgânica da Assistência Social (LOAS), que, em seu artigo $2^{\circ}$, inciso I, definiu, dentre seus objetivos, "a proteção à família, à maternidade, à infância, à adolescência e à velhice", nos moldes dos artigos 203 e 204 do texto constitucional de 1988.

Após 10 anos da edição da lei sobre a política nacional do idoso, em janeiro de 2004, entrou em vigor a Lei $n^{\circ} 10.741 / 2003$, denominada Estatuto do Idoso, estabelecendo regras de direitos para proteção às pessoas com idade igual ou superior a 60 (sessenta) anos.

Portanto, há, no Brasil, uma legislação moderna, na mesma linha do Estatuto da Criança e do Adolescente e do Código de Defesa do Consumidor. É um verdadeiro microssistema jurídico, regulamentando todas as questões que envolvem a pessoa idosa, tanto no aspecto material quanto processual. O Estatuto do Idoso está estruturado em sete Títulos, a saber: Título I - Das Disposições Preliminares; Título II - Dos Direitos Fundamentais, este composto de dez Capítulos; Título III - Das Medidas de Proteção, subdividido em dois Capítulos; Título IV - Da política de atendimento ao idoso, com seis Capítulos; Título V - Do acesso à Justiça, disciplinado em três Capítulos; Título VI - Dos Crimes, com dois Capítulos; e Título VII - Das Disposições Finais e transitórias, enfeixando 118 artigos.

Cabe esclarecer que o Estatuto do Idoso incorporou e reafirmou em seu texto, a doutrina da proteção integral, antes já utilizada no Estatuto da Criança e do Adolescente. Encontraremos ao longo do texto legal dispositivos que vêm para suprimir as deficiências sofridas pelos idosos no âmbito político esocial.

Enfim, a Lei $\mathrm{n}^{\mathrm{o}}$ 10.743/03 vem para consolidar a matéria jurídica relativa aos direitos e garantias do cidadão idoso. Afinal, o Brasil não é mais um país de jovens, mas um país em acelerado processo de envelhecimento. Esse perfil populacional exigirá do Estado e de toda sociedade ações efetivas para garantia dos direitos fundamentais das pessoasenvelhecidas.

O Estatuto assegurou aos idosos, em seu artigo $2^{\circ}$, todos os direitos fundamentais inerentes à pessoa, integral proteção, assegurando por lei ou por outros meios, todas as oportunidades e facilidades, para preservação de sua saúde física e mental e seu aperfeiçoamento moral, intelectual, espiritual e social em condições de liberdade edignidade.

Esses direitos não nasceram todos de uma vez, nem de uma vez por todas, mas sim, como todos os direitos humanos, não são um dado final, mas sim decorrentes de processos de construção e reconstrução para o alcance de evoluções. 
Dentro desse contexto, introduz a Constituição Federal de 1988 umavanço extraordinário na consolidação dos direitos e garantias fundamentais. De forma inédita, os direitos e garantias são elevados a cláusulas pétreas, e passam a compor o núcleo material intangível da Constituição (art. 60, $\S 4^{\circ}$ ). Cria-se uma nova ordem constitucional, em que a dignidade da pessoa humana e os direitos fundamentais tornam-se o ponto central dessa ordem jurídica. Tanto que, em seu preâmbulo, anunciou-se o propósito de construir um Estado Democrático pautado em uma sociedade fraterna, pluralista e sem preconceitos, onde esteja assegurada a igualdade, dentre os fundamentos que alicerçam o Estado Democrático deDireito.

Elevou em seu artigo $1^{\circ}$, inciso III, o valor da dignidade da pessoa humana como princípio fundamental desse novo Estado. Consagrou como objetivos fundamentais construir uma sociedade livre, justa e solidária, erradicar a pobreza e a marginalização e reduzir as desigualdades sociais e promover o bem de todos, sem preconceitos, de origem, raça, sexo, idade e quaisquer outras formas de discriminação ( $\operatorname{artigo} 3^{\circ}$ e incisos).

E, em seu Título II, a Constituição Federal definiu os "Direitos e Garantias Fundamentais", os quais abrangem os seguintes direitos: direitos individuais e coletivos; direitos sociais; direitos da nacionalidade; direitos políticos; direitos relacionados à existência, organização e participação em partidos políticos. O elenco de tais direitos deu-se através do caput e $\S 1^{\circ}$ do seu artigo $5^{\circ}$, que assegurou o princípio da igualdade, que passa a ser considerado dentro desse novo enfoque introduzido pela Lei Maior, como o valor mais alto dos direito fundamentais, funcionando como regra mestra de toda a hermenêutica constitucional e infraconstitucional. Assim, ao garantir a igualdade formal, o artigo $5^{\circ}$ cuidou, desde logo, de impedir que determinadas situações fossem prestigiadas sem qualquer correlação lógica. Portanto, o que verificamos é que a Constituição aproximou a igualdade formal da igualdade material, na medida em que não se limitou ao simples enunciado da igualdade perante a lei. "O princípio não pode ser entendido no sentido individualista, que não leve em conta as diferenças entre grupos." (LEITE, 2012, p.225).

Percebe-se que o constituinte destacou a responsabilidade do poder público, sem, contudo, desconsiderar o elemento da família e sociedade no amparo à população idosa. Consagrando, assim, o princípio dasolidariedade.

Seguindo a determinação constitucional, bem como a preocupação internacional, houve a edição da Lei $\mathrm{n}^{\mathrm{o}}$ 8.842/94 (Lei da Política Nacional do Idoso), que tem por objetivo assegurar os direitos sociais aos idosos, criando condições para promover sua autonomia, integração e participação efetiva na sociedade. 
Para dar maior proteção e concretização aos direitos desse segmento da população, o legislador ordinário elaborou o Estatuto do Idoso que além de reafirmar o direito à vida, à segurança, à liberdade, à propriedade, a saúde, à educação, ao lazer, ao trabalho, entre outros, que foram assegurados às demais pessoas, confere em seu artigo $2^{\circ}$, de forma inédita, direitos específicos e diferenciados os idosos, em observância a dois princípios: o da igualdade e o da proteçãointegral.

Desta forma, o idoso é titular de todos os direitos fundamentais, sem prejuízo da proteção integral que o estatuto confere.

\section{O idoso como sujeito de direitos}

Philippe Ariès (1981, p. 36) explica que "a velhice é uma criação cultural podendo encobrir significados diversos.

Simone de Beavoir (1990, p. 15) expõe que "a velhice é como um fenômenobiológico com reflexos profundos na psique do homem, perceptíveis pelas atitudes típicas da idade não mais jovem nem adulta, da idade avançada."

A Lei $\mathrm{n}^{\circ}$ 10.741, em seu artigo $1^{\circ}$, prevê a proteção: “É instituído o Estatuto do Idoso, destinado a regular os direitos assegurados às pessoas com idade igual ou superior a 60 (sessenta)anos."

Marco Antonio Vilas Boas (2005, p. 1-2) explica:

O vocábulo "idoso" tem sua origem latina no substantivo aetas, aetatis [substantivo feminino que corresponde à idade ou espaço de tempo humano], cujo caso acusativo aetatem (caso lexiogênico de onde nasceu a maioria das palavras num grande número de línguas modernas) deu-se existência à palavra "idade". "Idoso" é vocábulo de duas componentes: "idade" mais o sufixo "oso" que, no léxico, denota "abundância ou qualificação acentuada". Portanto, o vocábulo "idoso" pode significvar: cjeio de idade, abundante em idade, etc.

O Estatuto do Idoso, como microssitema de proteção ao grupo vulnerável assim, como o Estatuto da Criança e do Adolescente em relação às crianças e adolescentes, definiu, no artigo supracitado quem é o "idoso". Guilherme de Souza Nucci (2014, p. 451-452) esclarece que: 
O Estatuto do Idoso elegeu a idade de 60 anos para caracterizar a pessoa idosa, embora tenha sido assegurada a gratuidade dos transportes coletivos urbanos somente aos maiores de 65 anos [...]. Foi uma opção legislativa, afinal, anteriormente, quando o Código Penal se referia a velho, interpretava- se como sendo aquele que atingira 70 anos (idade, aliás, utilizada como parâmetro para aposentadoria compulsória do funcionário público e para o fím de cálculo atenuado da prescrição, conforme art. 115 do CP, bem como para a finalidade de se conceder atenuante ao criminoso, de acordo com o art. 65, I, também do CP. Temos, atualmente três estágios de idades: a) 60 anos, para ser uma pessoa considerada idosa; b) 65 anos, para que tenha o benefício do transporte coletivo público gratuito; c) 70 anos, para o fim de cálculo da prescrição, de concessão de atenuante e em relação à possibilidade de concessão de sursis para condenações a até quatro anos (sursisetário).

A lei civil, em seu artigo $2^{\circ}$ dispõe acerca da personalidade civil e, "assim sendo, a pessoa humana, durante sua vida, poderá passar por 5 (cinco) fases: nascituro, criança, adolescente, adulto e idoso, cada qual com critérios etários estabelecidos em normas legais infraconstitucionais" (RODRIGGUES, 2012, p. 443).

A preocupação com a proteção do idoso se mostra, cada vez mais necessária, tendo em vista o aumento da expectativa de vida e o envelhecimento da população seja efetivada em busca da dignidade humana e da cidadania.

As estatísticas demonstram um aumento considerável para o futuro, de pessoas idosas em nosso País, o que se deve, principalmente, aos avanços, sobretudo, da medicina e uma preocupação maior quanto à qualidade de vida dessas pessoas. Portanto, tal crescimento exige investimentos na adoção de políticas públicas, devendo o país estar preparado para dar-lhes condições dignas de existência. Enfim, não basta cuidar da saúde destas pessoasgarantindo uma longevidade maior, é também necessário cuidar para que vivam com mais qualidade de vida e, ainda, com dignidade (RUIZ; SENGIK, 2013. p. 315).

O envelhecimento deveria ter sido considerado pelo legislador como um processo tipicamente individual, existencial e subjetivo, afinal, cada existência humana é única, cada ser humano envelhece de maneira particular. Haveria necessidade de levar em consideração que cada indivíduo tem um tempo próprio para se sentir velho. Não há velhice e sim velhices (BRAGA, 2011, p.3).

Portanto, para desenvolver um conceito preciso sobre a velhice seria necessário considerar inúmeros fatores, uma vez que a velhice é um fenômeno complexo. A condição econômica dessas pessoas, seu grau de instrução, qual o tipo de alimento ingerido por elas, e como são suas relações familiares, dentre outros fatores. Nesse sentido, Paulo Roberto Barbosa Ramos, com base nas lições de Norberto Bobbio, Leonard Hayflick e Elida Séguin, afirma que 
para melhor compreensão do conceito de velhice, é necessário compreendê-la na perspectiva cronológica ou censitária, burocrática, fisiológica e psicológica ou subjetiva. A cronológica é aquela meramente formal. Parte de um patamar que, em sendo alcançado, identifica a quem o alcançou como velho. A velhice burocrática corresponde àquela idade que, em sendo alcançada, a pessoa terá direito a uma aposentadoria. A fisiológica pode ser identificada como a fragilização da pessoa em virtude do passar dos anos; aquela que diz respeito ao enfraquecimento do organismo. Já a subjetiva é a mais complexa, já que não dispõe de parâmetros. Depende de cada pessoa. Acrescenta também, a velhice excluída (aquela personificada por aqueles velhos que sobrevivem nos meios rurais, suburbanos ou após as migrações), a pseudo velhice (por pessoas de 40 anos ou menos, desempregadas) e a precoce (pessoas que, em razão de condições altamente adversas de existência, envelhecem muito cedo) (RAMOS, 2014, p. 34-35).

Todavia, o conceito eleito pelo legislador, em seu artigo $1^{\circ}$, foi o critério cronológico para definir quem é considerado idoso para os efeitos da presente lei. Sendo o idoso a pessoa como idade igual ou superior a 60 anos de idade, homem ou mulher, nacional ou estrangeiro, urbano ou rural, trabalhador da iniciativa privada ou do serviço público, livre ou recluso, exercendo atividades ou aposentado, incluindo o pensionista e qualquer que seja a sua condição social (MARTINEZ, 2005, p. 20). Porém, na prática, a maioria dos benefícios tem início aos 65 anos. Essa indefinição traz uma série de prejuízos em áreas importantes, cabe destacar o direito à gratuidade no transporte coletivo, que exige a idade mínima de 65 (sessenta e cinco) anos, segundo dispõe o artigo $230, \S 2^{\circ}$ da CF/88 e artigo 39, caput do Estatuto. Esta é também a idade exigida para obter prioridade na tramitação de processos judiciais, de acordo com a Lei $n^{\circ} 10.173$, de 9 de janeiro de 2001. E também o do benefício da prestação continuada nos termos do artigo 34, caput da Lei de Organização da Assistência Social - LOAS.

De qualquer modo, não podemos deixar de destacar que, o Estatuto reconheceuo acesso das pessoas com 60 (sessenta) anos ou mais o pleno gozo de seus direitos, bem como a uma efetiva inclusão nos diversos segmentos da comunidade e o bem-estar delas, garantindo o respeito e a preservação de suadignidade.

O cenário protetivo tem por objetivo associar a ideia de igualdade e a necessária proteção integral de forma que o Estatuto do Idoso seja um verdadeiro microssistema legislativo constituído por regras, normas e diretrizes de naturezas materiais e formais.

"Por se encontrar em momento peculiar da vida, a pessoa idosa necessita de integral e especial proteção para a garantia do envelhecimento sadio e digno, fornecendo-lhe todas as formas de assistência (pessoal - física, psíquica, emocional-, material, social, etc.) para o 
transcurso condigno dessa fase" (RODRIGUES, 2012, p. 447).

O idoso, na "última" etapa da vida, momento este frágil e vulnerável datrajetória humana, necessita de gama de tutelas específicas, de naturezas físicas, psíquicas e emocionais, pois a este momento etário deve ser garantido a pessoa uma vivência com os predicados de uma digna existência e o direito de envelhecer com dignidade.

Para corrigir o que antes foi afirmado, o atual entendimento acerca das pirâmides etárias é no sentido que esta chamada última fase da vida não se trata do fim, mas como uma especial etapa do desenvolvimento humano, com uma configuração inclusive institucional, uma conquista da sociedade aa qual, a partir do aumento da expectativa de vida da população, acaba por ter para a sua própria contribuição cultural, intelectual e social, a contribuição experiente do idoso para o aperfeiçoamento das relações.

A cidadania, no Brasil, teve um longo percurso, sendo conquistada com a efetiva ação dos movimentos sociais na defesa dos direitos humanos, e se revela como um fenômeno complexo e histórico e, na ausência de direitos civis e políticos, seu conteúdo e alcance tendem a ser arbitrários. Ele defende que os direitos sociais permitem às sociedades politicamente organizadas reduzir os excessos de desigualdade produzidos pelo capitalismo e garantir um mínimo de bem-estar para todos.

A justiça social é a idéia central em que se baseia a concepção de cidadania na modernidade, pois a ausência de uma população educada tem sido sempre um dos principais obstáculos à efetivação da cidadania civil e política, principalmenteno Brasil. O Estado brasileiro gradativamente desenvolveu e implantou uma legislação pautada nos Direitos Humanos para a populaçãoidosa.

A cidadania engloba os direitos como básicos para uma existência digna e a condição de cidadão devem ser respeitados, defendendo que os idosos tenham uma vida na velhice de forma digna.

\section{Das medidas específicas de proteção e a humanização e acolhimento à pessoa idosa}

A partir das ideias desenvolvidas nos itens anteriores, que demonstram a evolução histórica dos direitos dos idosos e aquelas que denotam a existência do idoso como sujeito de direitos, evolui-se para a questão das medidas específicas para tal tutela, pois o direito a envelhecer com dignidade é uma forma de proteção aos direitos humanos e este verbo indica "a ação natural no tempo que faz com que todo ser vivo envelheça, alterando sua aparência 
física, bem como as funcionalidades do seu corpo que passam a ser precárias" (ARRUDA; BORGES, 2017, p.371).

Esta precarização orgânica traz consigo a preocupação em assegurar a plena realização dos direitos das pessoas idosas, tanto no âmbito internacional como internamente, ambas ainda deficitárias quanto à concretização enquanto direitos fundamentais necessários à dignidade e acolhimento da pessoa idosa.

$\mathrm{Na}$ dimensão internacional, diferentemente de outros vulneráveis, como as pessoas com deficiência, o grupo de idosos não possui ainda tratados ou convenções internacionais em vigor, de caráter vinculante, para a defesa dos seus direitos fundamentais nos âmbitos dos sistemas regionais. Não há registros de Convenções Internacionais devidamente ratificadas e, nesse sentido, não há julgamentos assinalados nos julgamentos das cortes dos sistemas, por exemplo, nos regionais europeu ou interamericano.

Por necessário, portanto, o desenvolvimento de uma legislação de salvaguarda que vise assegurar o bem-estar e fomentar a adoção de políticas públicas de proteção do idoso, que vincule os Estados Internacionais, mas que sejam envoltas de um plexo de medidas,apontodealcançarahumanizaçãonecessáriaàgarantiadoexercíciodedireitos, prevendo as sanções e penalidades que para cada tipo de violação, inclusive no âmbito da responsabilidade civil indenizatória internacional para o caso de não observância.

De outro lado, o Brasil, como Estado Democrático de Direito e em busca da cidadania e da conformação de uma sociedade justa, em âmbito interno, possui ordenamento normativo específico, insertos todos na lei 10.741 , de 3 de outubro de 2003, em seu artigo 43 prevê medidas de proteção, assim como o estatuto da criança e do adolescente, de tutela da criança e do adolescente em situações de risco, pessoal ou social em razão de sua vulnerabilidade etária, emocional e psicológica próprios da fase davida.

Assim, quanto ao idoso, a legislação mencionada prevê em seu artigo 43, as situações fáticas e jurídicas que ensejarão a aplicação das medidas de proteção por ameaça ou violação aos direitos da pessoa idosa, quais sejam: I- Por ação ou omissão da sociedde ou do Estado; II - Por falta, omissão ou abuso da família, curador ou entidade de atendimento; III - Em razão de sua condição pessoal.

Diante dessas condições, Oswaldo Peregrina Rodrigues (2012, p. 500) esclareceque:

Ameaçados ou violados quaisquer direitos da pessoa idosa por ato comissivo ou omissivo do Poder Público, da família e de seu curador, da entidade que o atende - aqueles que têm o dever jurídico de protegê-la -, ou mesmo por sua peculiar condição pessoal, esse idoso se encontrará em situação de risco, demandando a respectiva proteção, com o fito de afastar ou amenizar as ameaças e violações. 
Nesse manto protetivo, o idoso no Brasil tem em sua proteção igualmente o artigo 45 do estatuto, com previsão específica que dispõe acerca das medidas específicas de proteção, em situações em que a pessoa idosa se encontre em situação de risco, pessoal ou social, delineadas no dispositivo anteriormente citado.

A depender da situação de risco concreto, referidas medidas serão aplicadas, isolada ou cumulativamente, de forma preventiva ou repressiva, com o fim de almejar a finalidade social e o restabelecimento e manutenção dos vínculos familiares e comunitários do idoso, conforme o parágrafo $3^{\circ}$ do artigo 44, do Estatuto doIdoso.

As medidas específicas previstas no artigo 45 visam o restabelecimento da convivência familiar (natural ou substitutiva), a adequação da convivência comunitária,até o eventual acolhimento da pessoa idosa em entidades de abrigo e, havendo impossibilidade, ainda que temporária, da permanência no âmbito familiar.

Destaca-se que a medida poderá ser consubstanciada pelo apoio e tratamento à saúde física, mental, clínica e psicológica.

Anote-se que a Secretaria de Direitos Humanos da Presidência da República colocou à disposição da população o "Disque 100", que, ao chamar, a Ouvidoria Nacional dos Direitos Humanos receberá e examinará as denúncias e reclamações de atos que envolvam de atos que envolvam violações aos direitos humanos, "podendo agir de ofício, atuando diretamente ou em articulação com outros órgãos públicos e organizações da sociedade” (BRASIL, 2018).

Alterações foram realizadas ao longo dos 15 (quinze) anos de vigência do Estatuto, com destaque para a Lei $n^{\circ} 11.765 / 2008$, que incluiu oi inciso $\mathrm{X}$ ao artigo $3^{\circ}$ do EI, dando prioridade aos idosos ma restituição do imposto de renda, a Lei ${ }^{\circ} 11.737 / 2008$ relativa aos alimentos, a Lei n ${ }^{0}$ 12.461/2011 que dispõe acerca da notificação compulsória pelos órgãos de saúde pública e privada, as Leis $\mathrm{n}^{\circ} 12.418$ e 12.419 de 2011 , tratando da reserva de unidades habitacionais, como exemplos.

O Estatuto do Idoso estabelece diretrizes claras para a garantia efetiva dos direitos desta população, porém, depende da implementação de ações positivas para a efetivação desta garantia e, somente assim, será possível o "envelhecimento ativo" e existência digna nesta fase da vida.

A Política Nacional de Humanização por meio de dispositivos prevê o acolhimento ao idoso, postura adotada pelo Estado na área da saúde, em específico, com ações ativas de compartilhamento de saberes do profissional da área da saúde, com conhecimento das 
necessidades e possibilidade da pessoaidosa.

A efetivação do acolhimento da saúde se dá em respeito aos direitos inerentes à pessoa idosa, em que os profissionais da área da saúde devem compreender as especificidades dessa população e, a família, a sociedade e o Estado devem respeitar a gama de normas protetivas, bem como participar das condições de melhoria da qualidade de vida doidoso.

O conhecimento do processo de envelhecimento merece destaque na sociedade, inclusive com alteração na consolidação cultural da população brasileira, vez que, em razão do aumento da expectativa de vida e o respeito ao direito de envelhecer com dignidade é que se atingirá a cidadania e o efetivo Estado Democrático de Direito.

O ordenamento se preocupou com vários aspectos da vida do idoso, o queproporcionou uma proteção mais global, protegendo ao idoso a convivência em família, sem ser alijado do convívio social, com seus direitos humanos assegurados.

Importante destacar que o maior entrave às políticas de valorização dos idosos no Brasil para a proteção ao idoso centra-se ainda na questão cultural que permite de forma subjacente os desafios aos direitos fundamentais dos idosos de forma reiterada, que vão desde a saúde pública, proteção no emprego, subsistência alimentar, o que deve ser analisado por meio de representações sociais, que se trata do conjunto de conceitos e explicações originadas da vida.

Segundo Spink (2003), as representações sociais são formas de conhecimento social que orientam a ação, individual ou institucional, para a prevenção de doenças e de promoção da saúde. Quanto ao idoso, a Sociedade Brasileira de Geriatria e Gerontologia conclui que a sociedade não está preparada para lidar com o processo de envelhecimento, pois $85 \%$ dos idosos no Brasil tem doenças crônicas (RAMOS, KALACHE, 2003). Esta identificação de doenças crônicas demonstra um outro problema maior: ao do Estado que se recusa a assumir custos comesta

As representações sociais de idosos sobre a qualidade de vida nesta fase se constroem sustentadas, em especial, nos determinantes sociais, "ao encontro do discurso da produção social de saúde, o que demonstra uma compreensão global do conceito de qualidade de vida" (FERREIRAL; TURAL; SILVA, 2017).

Uma vez que o "bem envelhecer" é respaldado no ordenamento jurídico e é de responsabilidade da família, da sociedade e do Estado; sendo que este deve criar condições para que este grupo vulnerável tenha uma qualidade de vida por meio de da garantia dos direitos dos idosos. 
Fenômenos esperados como relativos ao Estado Democrático em respeito a dignidade humana do idoso, à humanização nas tutelas específicas de suas necessidades e o respeito aos demais direitos fundamentais dos idosos não se completam pela ausência de reconhecimento moral pela própria sociedade brasileira, não obstante haja um plexo normativo protetivo nessesentido.

\section{Considerações finais}

A partir da pesquisa realizada alcançou-se os objetivos propostos na introdução no sentido de registrar os avanços históricos para a consolidação dos direitos eprioridades inerentes à vulnerabilidade do idoso, para reconhecer a pessoa idosa como sujeito de direitos e de receber tratamento digno da família, do Estado e da sociedade, com vistas a alcançar, inclusive, uma mudança cultural na dimensão social em que a sociedade entenda envelhecimento enquanto processo de evolução natural das pessoas e que não pode ser visto como um processo dissociado das ações específicas de atingimento à humanização no tratamento dedicado a este segmento.

Nesse pensamento, a cidadania, tendo como ponto de partida as pessoas idosas precisam se conscientizar de que esses direitos existem, autoridades e demais cidadãos devem agir no sentido de afirmá-los do contrário de nada terá adiantado todo o esforço para sua elaboração e vigência. A lei por si só, como se tem visto, não é capaz de mudar a realidade. Ela necessita da disposição de todos no sentido de cumpri-la. Assim, para uma maior efetivação de todos os direitos fundamentais das pessoas idosas, faz-se necessário que tanto a sociedade, como também a família e o Poder Público implementem políticas públicas a fim de se conferir a efetiva inclusão dessas pessoas em nossacomunidade.

O sistema jurídico pátrio oferece garantias de proteção aos idosos para a concretização do respeito à dignidade humana e a cidadania, não obstante a densa maioria da população brasileira não os tenha ainda inserido no que se denomina cultura da população e dos gestores públicos, que permanecem a classificar os idosos como um peso social. É nesse sentido que se concretizam as representações sociais elaboradas em torno desta vulnerabilidade: uma postura de descaso, tanto no âmbito privado como no tocante às políticas públicas.

Para a efetivação de tais direitos, necessária à implementação de ações positivas pelo Estado para que de fato ocorram a proteção e a participação desse grupo de vulneráveis na sociedade, para o fim proposto neste trabalho se atingir a dignidade humana no desenho de uma sociedade justa. 
A abordagem das medidas específicas de proteção e humanização e acolhimento à pessoa idosa deve ser no sentido de implementá-las de forma inter-setorial, aplicando- se lhes os dispositivos estatutários e protetivos no alcance das diretrizes claras para a esta garantia, a seguir-se o disposto na Constituição Federal e nos tratados internacionais de direitos humanos, sendo que tal sistema é considerado avançado pelo Ministério da Saúde, porém, ainda necessita de implementação de políticas públicas para que esses direitos sejam efetivamenteprotegidos.

\section{Referências bibliográficas}

ARENDT, Hannah. A condição humana. Tradução de Roberto Raposo. 10.ed. Rio de Janeiro: Forense Universitária, 2004.

ARRUDA, Camila Rabelo de Matos; BORGES, Leticia Maria Coelho. Direitos dos Idosos, uma reflexão sobre suas garantias. In:? GURGEL, Claudia; MELLO, Cleyson de Moraes; GUERRA, Sônia (coord. Geral). Estudos em Homenagem a André Fontes: Dignidade, Direito e Filosofia. Juiz de Fora: Editar Associada Ltda, 2017, p.371-384.

BEAUVOIR, Simone de. A velhice. Tradução de Maria Helena Franco Martins. Rio de Janeiro: Nova Fronteira, 1990.

BRAGA, Pérola Melissa Vianna. Curso de direito do idoso. São Paulo: Atlas, 2011.

BRASIL. Estatuto do Idoso. Disponível em: $\Varangle$ http://www.planalto.gov.br/ccivil_03/ leis/2003/L10.741.htm>. Acesso em: 15 mai. 2018.

Ministério da Saúde. Envelhecimento e Saúde da Pessoa Idosa. Cadernos de Atenção Básica. N. 19. 2006. Brasília. Disponível em: <http://189.28.128.100/dab/docs/ publicacoes/cadernos_ab/abcad19.pdf>. Acesso em: 15 mai. 2018.

CÍCERO, Marco Túlio. Saber envelhecer-Seguido de A amizade. Tradução de Paulo Neves. Porto Alegre: L \& PM, 2001. 
CRESCENZO, Luciano de. História da filosofia grega - a partir de Sócrates. Lisboa:

Presença, 1988.

CONFÚCIO. Vida e doutrina: os analectos. Tradução de Múcio Porphyrio Ferreira. São Paulo: Pensamento,1999.

DARÉ, Geisa Oliveira. Direito ao esquecimento. Bauru: Canal 6, 2015.

FALEIROS, Vicente. Envelhecimento no Brasil: desafios e compromissos. In: Conselho Federal de Psicologia (org.). Envelhecimento e subjetividade: desafios para uma cultura de compromisso social. Conselho Federal de Psicologia: Brasília,2008.

FERREIRAL, Marielle Cristina Gonçalves; TURAL , Luiz Fernando Rangel; SILVA, Rafael Celestino da; FERREIRAL, Márcia de Assunção. Social representations of older adults regarding quality of life. Rev Bras Enferm [Internet]. 2017;70(4):806-13. [Thematic Edition "Good Practices: Fundamentals of care in Gerontological Nursing”] Disponívelem: $<$ http://dx.doi.org/10.1590/0034-7167-2017-0097>. Acesso em: 15 mai. 2018.

IBGE. População. Disponível em: ‘https://www.ibge.gov.br/apps/populacao/projecao/>. Acesso em: 15 mai.2018.

KEINERT, Tânia Margarete Mezzomo; ROSA, Tereza Etsuko da Costa. Direitos Humanos, envelhecimento ativo e saúde da pessoa idosa: marco legal e institucional. Boletim do Instituto de Saúde. ISSN 1518-1812. BIS, Bol. Inst. Saúde (Impr.). n. 47.São Paulo abr.2009. Disponível em: \http://periodicos.ses.sp.bvs.br/ scielo.php?script=sci_arttext\&pid=S1518-18122009000200002\&lng=pt\&nrm=iso\&tlng=pt $>$. Acesso em: 15 mai.2018.

LEITE, Flávia Piva Almeida. Cidades acessíveis. São Paulo: SRS, 2012.

NUCCI, Guilherme de Souza. Leis Penais e Processuais Penais Comentadas v. 1. 8. ed. Rio de Janeiro: Forense, 2014.

ONU. Declaração Universal dos Direitos Humanos. 1948. Disponível 
em: $<$ http://www.onu.org.br/img/2014/09/DUDH.pdf $>$. Acesso em: 15 mai. 2018.

PLATÃO. A república. Tradução de Elza Moreira Marcelina. Brasília: UnB, 1985. Livro 7.

RAMOS, Paulo Roberto Barbosa. Curso de direito do idoso. São Paulo: Saraiva, 2014.

RODRIGUES, Oswaldo Peregrina. Direitos do Idoso. In: NUNES JUNIOR, Vidal Serrano (coord.). Manual de Direitos Difusos. 2. ed. São Paulo: Verbatim, 2012, p. 439- 547.

RUIZ, Ivan Aparecido; SENGIK, Kenza Borges. A tutela dos direitos da personalidade dos idosos mediante implementação de políticas públicas, como forma de acesso à Justiça. In: SIQUEIRA, Dirceu Pereira; SILVA, Nilson Tadeu Reis Campos (orgs.). Minorias e grupos vulneráveis: reflexões para uma tutela inclusiva. Birigui: Boreal, 2013. p. 305-337.

SÁ, Celso P. Representações sociais: o conceito e o estado atual da teoria. In: SPINK,M.J. (Org). O conhecimento no cotidiano: as representações sociais na perspectiva da psicologia social. São Paulo: Brasiliense,1993. p. 19-45.

SENNET, Richard. A carne e a pedra. Tradução Marco Aarão Reis. Rio de Janeiro:

BestBolso, 2008. 


\title{
O EXERCÍCIO PROGRESSIVO DOS DIREITOS DA CRIANÇA: AS PREMISSAS \\ DA CORTE INTERAMERICANA DE DIREITOS HUMANOS SOB A PERSPECTIVA DOS ACORDOS ARGUMENTATIVOS PROPOSTOS POR PERELMAN E OLBRECHTS-TYTECA
}

\author{
Sergio Ruiz Díaz Arce \\ Universidade de Brasília
}

\section{Resumo}

A concepção da infância tem um caráter especial devido ao processo de construção que tem sofrido ao longo da sua história até finalmente obter a condição jurídica de sujeito de direitos. Todavia, apesar de contar com proteção e reconhecimento jurídico, as crianças e adolescentes continuam sendo um grupo de pessoas com limitações para o exercício de seus direitos. Partindo destas limitações, este artigo tem como objetivo distinguir e analisar as premissas argumentativas utilizadas pela Corte Interamericana de Direitos Humanos em suas decisões contenciosas sobre o exercício progressivo de direitos por parte de crianças e adolescentes. Assim, utiliza-se os aportes teórico-metodológicos propostos por Perelman e Olbrechts-Tyteca, especialmente sobre os acordos argumentativos que visam alcançar a adesão dos auditórios para os quais vão dirigidos. Nesse sentido, esta pesquisa procura mostrar a importância do sistema interamericano de justiça na construção de premissas argumentativas, além de garantir os direitos consagrados nos instrumentos internacionais de direitos humanos.

Palavras-chaves: Direitos da criança, Exercício progressivo de direitos, Corte Interamericana de Direitos Humanos, Argumentação jurídica.

\section{Abstract/Resumen/Résumé}

La concepción de infancia tiene un carácter especial debido al proceso de construcción que ha sufrido a lo largo de su historia hasta finalmente obtener la condición jurídica de sujeto de derechos. Sin embargo, a pesar de contar con protección y reconocimiento jurídico, los niños, niñas y adolescentes continúan siendo un grupo de personas con limitaciones para el ejercicio de sus derechos. Acerca de estas limitaciones, este artículo tiene como objetivo distinguir y analizar las premisas argumentativas utilizadas por la Corte Interamericana de Derechos Humanos en sus decisiones sobre el ejercicio progresivo de derechos por parte de niños, niñas 
y adolescentes. Para ello, se utilizan los aportes teórico-metodológicos propuestos por Perelman e Olbrechts-Tyteca, especialmente sobre los acuerdos argumentativos encaminados a lograr la adhesión de los auditorios a los cuales va dirigido. En tal sentido, esta investigación pretende mostrar la importancia del sistema interamericano de justicia en la construcción de premisas argumentativas, además de garantizar los derechos consagrados en los instrumentos internacionales de derechos humanos.

Keywords/Palabras-claves/Mots-clés: Derechos del niño, Ejercicio progresivo de derechos, Corte Interamericana de Derechos Humanos, Argumentación jurídica.

\section{Introdução}

Quando as Nações Unidas adotaram a Convenção sobre os Direitos da Criança (CDC) em 1989, iniciou-se uma nova etapa na concepção da infância, reconhecendo-se que as crianças e os adolescentes têm direitos assim como as pessoas adultas, salvo a limitação condicionante de que as crianças e os adolescentes estão numa etapa de evolução, que ao mesmo tempo leva consigo uma responsabilidade do estado e da sociedade. Diante da instauração deste novo quadro legal estabelecido pela CDC, o chamado sistema de situação irregular é abandonado para incorporar um sistema de proteção integral e a instalação de um novo paradigma no enfoque do estado sobre as crianças e adolescentes, que passam a ser sujeitos ativos de seus direitos em todas as esferas nas quais atuam. Esta confirmação do status jurídico das crianças e dos adolescentes como sujeitos de direito, condição inerente a toda pessoa humana, carrega também consequências que transcendem o âmbito meramente jurídico, pois o reconhecimento desta condição constitui o ponto de partida para a reflexão e a análise sobre a situação das crianças e adolescentes e o lugar deles na sociedade. Desta forma, este novo enfoque de direitos que aparece junto com a CDC supõe um abandono de antigas práticas vinculadas à infância, mediante uma concepção que os inclui na categoria de "pessoas", apresentando-nos assim às crianças e adolescentes como seres humanos livres e com direitos plenos.

Porém, os limites para o exercício de esses direitos por parte de crianças e adolescentes têm gerado uma série de questões no momento de interpretar a CDC, devido que o citado instrumento legal sinala que o exercício de direitos depende da "autonomia progressiva" de seus titulares. Ante esta situação, nos encontramos com um sujeito que é portador de direitos a quem se reconhece capacidade para exercê-los individualmente, mas ao mesmo tempo, com 
uma autonomia relativa devido a considerações de fato, que tem que a ver com a maturidade; e considerações de direito, referidas à construção jurídica tradicional de crianças e adolescentes como pessoas dependentes de sujeitos adultos, em particular dos pais e, às vezes, do estado.

Diante disso, a Corte Interamericana de Direitos Humanos (IDH) proporciona por meio de suas decisões uma série de diretrizes para medir o grau de avanço na aplicação das normas de internacionais de direitos humanos, como também avançar no desenvolvimento de temas específicos que precisem de um maior estudo e claridade para sua compreensão. Por esta razão, a Corte IDH tem uma posição privilegiada ao gozar de certa supremacia hermenêutica na interpretação da CDC, devido que a partir de suas decisões se constroem os acordos que posteriormente são dirigidos aos auditórios nacionais. Neste sentido, segundo os argumentos apresentados pelo tribunal nos casos contenciosos, pode-se perguntar quais são as premissas utilizadas pela Corte IDH em suas decisões sobre exercício progressivo de direitos por parte de crianças e adolescentes?

A hipótese levantada neste trabalho é que, ainda que juridicamente a condição de pessoa humana para as crianças e os adolescentes tenha gerado mudanças e reformas legislativas por causa da $\mathrm{CDC}$, o exercício de direitos por parte destes está condicionado às limitações impostas pelas instituições de justiça no momento de julgar. Essas limitações encontram amparo especialmente em dois condicionantes: falta de maturidade e proteção especial.

Assim, o objetivo desta investigação é identificar os acordos utilizados pela Corte IDH em suas decisões sobre o exercício progressivo de direitos por parte das crianças e dos adolescentes. Para isso, primeiro realizou-se uma revisão da jurisprudência da Corte IDH sobre casos que afetam a crianças e adolescentes no exercício progressivo de seus direitos. Posteriormente, se estabelece comparações entre as decisões tomadas pela Corte IDH utilizando o esquema de classificação de premissas proposta por Chaïm Perelman e Lucie OlbrechtsTyteca. Esta investigação encontra fundamento na necessidade de seguir avançando em matéria de direitos para as crianças e adolescentes na América Latina, principalmente no que se refere ao sistema de justiça, aplicação de normas e, particularmente, sobre a argumentação dos juízes.

\section{Fundamentação teórico-metodológica}

O presente artigo toma como base de estudo a obra de Chaïm Perelman e Lucie Olbretchts-Tyteca (2005) titulada "Tratado da argumentação, a nova retórica", cujo enfoque centra-se no conteúdo dos argumentos e sua aceitação, a qual pode ser entendida como a 
pretensão do orador em lograr a adesão do auditório ao qual se dirige. Deste modo, esses autores questionam o enfoque lógico cartesiano da ciência moderna, motivo pelo qual realizam um resgate da retórica aristotélica e propõem uma "nova retórica" na qual se analisa se o argumento que procura lograr a adesão de um auditório é persuasivo ou convincente. Em relação as decisões judiciais, afirma-se que as mesmas estão mais encaminhadas para a persuasão que para a demonstração.

Sobre esta nova retórica, um dos aportes mais importantes é, sem dúvida, a classificação de auditórios em "particular" e "universal". O primeiro abarca um grupo limitado de pessoas que compartem entre si certas convenções, as quais, por sua vez, são compartilhadas pelos demais indivíduos como, por exemplo, os habitantes de um povo, um grupo de pesquisadores ou uma turma de estudantes. Por outro lado, o auditório universal pode ser considerado como o auditório da argumentação filosófica que abarca a todas as pessoas razoáveis, onde o orador pressupõe a unanimidade e, por conseguinte, a universalidade da argumentação, pois supõe que quem conhece sobre determinados argumentos não pode fazer outra coisa que admiti-las devido à objetividade com que contam as razões aludidas. Sobre a mencionada objetividade, não é aquela relacionada à lógica cartesiana, senão aquela que se encontra no campo do verossímil.

De acordo com Perelman e Olbretchts-Tyteca, a análise dos argumentos se inicia com o que é aceito como pontos de partida dos raciocínios. A partir desses acordos vão se construindo as estratégias da argumentação que contém um conjunto de procedimentos de enlace e dissociação com o intuito de lograr a adesão do auditório sobre os raciocínios do orador. Desta maneira, em todo processo de argumentação o orador começa com a eleição das premissas que sustentarão o discurso e a formulação das mesmas. Assim, a eleição das premissas e sua formulação estão carregadas de um valor argumentativo entendido como uma preparação ou um raciocínio encaminhado para o uso persuasivo.

O presente artigo se limita a analisar as premissas contidas nos tipos de acordo propostos por Perelman e Olbretchts-Tyteca aplicado às decisões da Corte IDH. Sobre os acordos mencionados, os autores consideram que podem ser classificados em dois grandes grupos: acordos relativos ao real, que versam sobre os fatos, as verdades e as presunções, e, acordos relativos ao preferível, que tem relação com os valores, as hierarquias e os lugares do preferível. De modo geral, pode-se dizer que no processo argumentativo toda afirmação que faz referência ao real busca validez frente a um auditório universal; enquanto aquilo que faz referência ao preferível, está vinculado a um ponto de vista concreto, limitado, que se identifica com o auditório particular. 
Para esta pesquisa que tem como objeto a análise dos argumentos da Corte IDH, a técnica de análise empregada é de estudo de casos a partir de um modelo de classificação de premissas. Para a mesma, foram selecionadas três decisões da Corte IDH, cada uma com questões controvertidas diferentes. Destarte, a identificação de premissas não foi feita sobre os problemas de fundo que contém cada decisão, mas sim sobre a questão específica relacionada ao exercício de direitos por parte das crianças e dos adolescentes que se desenvolvem de maneira acessória dentro de cada uma das decisões. Aliás, foi realizada a identificação das premissas utilizadas pela Corte IDH em suas considerações relativas ao exercício progressivo de direitos por parte de crianças e adolescentes, conforme o esquema classificatório proposto por Perelman e Olbretchts-Tyteca.

Quadro 1: Modelo de esquema para a análise dos acordos.

\begin{tabular}{l|ll} 
Premissas & Caso $1^{1}$ & Caso $2^{2}$ \\
\hline Relativo ao real & & \\
Fatos & & \\
Verdades & & \\
Presunções & & \\
Relativo ao preferível & \\
Valores & \\
Hierarquias & \\
Lugares & \\
\hline
\end{tabular}

Fonte: elaboração própria.

\section{Premissas relativas ao real}

Neste grupo de premissas encontramos primeiramente os fatos que fazem referência a certos dados da realidade objetiva, que se caracterizam por não precisar, a priori, de argumentos que reforcem sua adesão, nem são usualmente objeto de controvérsias; quer dizer, do ponto de vista argumentativo existe um acordo universal, sobre o qual, afirma-se que: “[...] a intensidade de adesão não tem de ser aumentada, nem de ser generalizada, e que essa adesão não tem nenhuma necessidade de justificação [...]” (PERELMAN; OLBRECHTS-TYTECA, 2005, p. 75). Assim, os fatos aceitados podem ser fatos de observação, fatos supostos, conveniados,

\footnotetext{
1 Caso Gelman Vs. Uruguay. Fondo, Reparaciones y Costas. Sentença de 24 de fevereiro de 2011 $<$ http://www.corteidh.or.cr/cf/Jurisprudencia2/ficha_tecnica.cfm?lang=es\&nId_Ficha=345> (01 jun. 2017).

${ }^{2}$ Caso Atala Riffo y Niñas Vs. Chile. Fondo, Reparaciones y Costas. Sentença de 24 de fevereiro de 2012 $<$ http://www.corteidh.or.cr/cf/Jurisprudencia2/ficha_tecnica.cfm?lang=es\&nId_Ficha=196> (01 jun. 2017).

${ }^{3}$ Caso Furlan y Familiares Vs. Argentina. Excepciones Preliminares, Fondo, Reparaciones y Costas. Sentença de 31 de agosto de $2012<$ http://www.corteidh.or.cr/cf/jurisprudencia2/ficha_tecnica.cfm?nId_Ficha=210> (01 jun. 2017).
} 
possíveis ou prováveis; qualquer um destes deve se adequar às estruturas do real admitidas pelo auditório.

\begin{abstract}
Mas, por conseguinte, a nenhum enunciado é assegurada a fruição definitiva desse estatuto, pois o acordo sempre é suscetível de ser questionado e uma das partes do debate pode recusar a qualidade do fato ao que afirma seu adversário. Haverá, portanto dois modos normais para que um acontecimento perca o estatuto de fato: quando são levantadas dúvidas no seio do auditório ao qual ele fora apresentado e quando se amplia esse auditório, acrescendo-lhe outros membros cuja qualidade para julgar é reconhecida e que não admitem que se trata de um fato. Esse segundo processo entra em jogo a partir do momento em que é possível mostrar eficazmente que o auditório que admita o fato é apenas um auditório particular, a cujas concepções se opõem a dos membros de um auditório ampliado. (PERELMAN; OLBRECHTS-TYTECA, 2005, p. 76).
\end{abstract}

No que se refere aos direitos das crianças e dos adolescentes, os acordos sobre a concepção da infância são o resultado de um processo de transição de paradigmas relativamente novo que outorga aos novos sujeitos de direitos a condição de pessoa e ao mesmo tempo supõe o abandono de uma milenária tradição que os colocava juridicamente em uma categoria inferior aos demais seres humanos. Em consequência, os princípios gerais ou aqueles de caráter universal citados na CDC estão principalmente encaminhados a assegurar a condição de pessoa das crianças e dos adolescentes, recentemente adquirida para colocá-los na mesma posição que os adultos.

Deste modo, os fatos que prevaleceram antes da $\mathrm{CDC}$, perderam seu estatuto e foram deslocados para dar lugar aos que conhecemos atualmente. A Corte IDH destaca nos casos analisados, que as crianças e os adolescentes são sujeitos titulares de direitos humanos e que os mesmos exercem seus direitos de forma progressiva. Ambas premissas se encontram presentes nos três casos e são utilizadas para reafirmar a condição jurídica destes e garantir sua participação dentro de um processo judicial. Contudo, enquanto ao exercício progressivo de direitos, a Corte entende que estes dois fatos estão submetidos à intervenção dos pais e das condicionantes relacionadas à maturidade física e mental. Desta forma se tem: 
Quadro 2: Premissas relativas ao real. Fatos

\begin{tabular}{|c|c|c|c|}
\hline Fatos & $\begin{array}{l}\text { Caso } 1 \\
\text { "[...] as crianças e } \\
\text { adolescentes são sujeitos } \\
\text { titulares de direitos } \\
\text { humanos". (Párr. 129) } \\
\text { "[...] as crianças e } \\
\text { adolescentes exercem seus } \\
\text { direitos de maneira } \\
\text { progressiva na medida que } \\
\text { desenvolvem um maior } \\
\text { nível de autonomia } \\
\text { pessoal". (Párr. 129) } \\
\text { "[...] as crianças e } \\
\text { adolescentes na sua } \\
\text { primeira infância exercem } \\
\text { seus direitos por conduto } \\
\text { de seus familiares". (Párr. } \\
68 \text { ) }\end{array}$ & $\begin{array}{l}\text { Caso } 2 \\
\text { "[...] por outra parte, a Corte } \\
\text { reitera que as crianças e } \\
\text { adolescentes exercem seus } \\
\text { direitos de maneira progressiva } \\
\text { na medida que desenvolvem } \\
\text { um maior nível de autonomia } \\
\text { pessoal". (Párr. 199) } \\
\text { "[...] as crianças e adolescentes } \\
\text { na sua primeira infância } \\
\text { exercem seus direitos por } \\
\text { conduto de seus familiares". } \\
\text { (Párr. 68) }\end{array}$ & $\begin{array}{l}\text { Caso } 3 \\
\text { “[... as crianças e } \\
\text { adolescentes exercem seus } \\
\text { direitos de maneira } \\
\text { progressiva na medida que } \\
\text { desenvolvem um maior } \\
\text { nível de autonomia } \\
\text { pessoal”. (Párr. 230) }\end{array}$ \\
\hline
\end{tabular}

Fonte: elaboração própria.

Esta intervenção autorizada aos pais para que as crianças e adolescentes exerçam seus direitos aparece no Caso 1 quando se faz referência ao nascimento em cativeiro de uma menina. Sobre isso, a Corte assinala que a retenção física por parte de agentes estatais, sem o consentimento de seus pais, implica uma afetação à liberdade da menina; quer dizer, a separação da menina de seus pais afeta a liberdade pessoal dela. Então, é possível afirmar que temos um sujeito titular de direitos humanos cuja liberdade pessoal está associada à de outras pessoas. Assim, a Corte IDH indica que "a separação de uma criança de seus familiares implica, necessariamente, um menoscabo no exercício de sua liberdade" (Caso 1, párr. 129).

No que se refere às condicionantes de maturidade física e mental, a Corte indica no Caso 2 como o exercício progressivo de direitos está diretamente relacionado com a idade. Aqui, surge a importância da participação de três meninas dentro de um juízo; sobre isso, a Corte entende que devido ao fato das meninas não possuírem a mesma idade, as opiniões de cada uma delas tampouco serão iguais, quer dizer, a idade determina a importância da participação.

Evidentemente, hay gran variedad en el grado de desarrollo físico e intelectual, en la experiencia y en la información que poseen cada niña o niño. Por tanto, al llevarse a cabo la diligencia realizada según lo dispuesto en la mencionada Resolución [...] se tuvo en cuenta que las tres niñas tienen en este momento 12, 13 y 17 años de edad y, por tanto, podrían existir diferencias en sus opiniones y en el nivel de autonomía personal para el ejercicio de los derechos de cada una. (Caso 2, párr. 68). 
À análise dos fatos segue a análise das denominadas verdades. Como já foi mencionado, fala-se de fatos quando se alude a objetos de acordos precisos ou limitados; contudo se faz referência às verdades quando se fala de sistemas mais complexos, relativos aos enlaces entre fatos, relacionadas a teorias científicas, concepções filosóficas ou religiosas, ou sistemas que transcendem à experiência e contam com um alcance mais geral.

O mais das vezes, utilizam-se fatos e verdades (teorias científicas, verdades religiosas, por exemplo) como objetos de acordo distintos, mas entre os quais existem vínculos que permitem a transferência do acordo: a certeza do fato A, combinado com a crença no sistema $\mathrm{S}$, acarreta a certeza do fato $\mathrm{B}$, o que significa que admitir o fato $\mathrm{A}$, mais a teoria S, equivale admitir B. (PERELMAN; OLBRECHTS-TYTECA, 2005, p. 78).

O sistema de normas que conformam a CDC e a Convenção Americana de Direitos Humanos, além de outros instrumentos, são considerados um conjunto de premissas verdadeiras que gozam de credibilidade para a elaboração dos acordos. Nos casos selecionados, identificamse principalmente as normas relacionadas à liberdade e à participação; ambas estreitamente vinculadas ao exercício progressivo de direitos:

Quadro 3: Premissas relativas ao real. Verdades

\begin{tabular}{l|l|l} 
Verdades & $\begin{array}{l}\text { Caso 1 } \\
\text { Artigo 7: Direito à liberdade pessoal. } \\
\text { (Convenção Americana de DDHH) }\end{array}$ & $\begin{array}{l}\text { Caso 2 e Caso } 3 \\
\text { Artigo 12: Opinião da criança. (Convenção } \\
\text { sobre os Direitos da Criança) }\end{array}$ \\
$\begin{array}{l}\text { 1. Toda pessoa tem direito à liberdade } \\
\text { e à segurança pessoal. }\end{array}$ & $\begin{array}{l}\text { 1. Os estados partes garantirão à criança que } \\
\text { esteja em condições de se formar em juízo } \\
\text { 2. Ninguém pode ser privado de sua o direito de expressar sua opinião } \\
\text { liberdade física, salvo pelas causas e } \\
\text { nas condições estabelecidas de } \\
\text { antemão pelas Constituições Políticas } \\
\text { dos estados artes ou pelas leis ditadas } \\
\text { conforme elas. }\end{array}$ & $\begin{array}{l}\text { livente em todos os assuntos que os afete, } \\
\text { tendendo-se devidamente em conta as opiniões } \\
\text { da criança, em função da idade e maturidade da } \\
\text { criança. } \\
\text { 2. Para tal fim, se dará em particular a criança } \\
\text { oportunidade de ser escutada, em todo } \\
\text { procedimento judicial ou administrativo que } \\
\text { afete a mesma, seja diretamente ou por meio de } \\
\text { um representante ou de um órgão apropriado, } \\
\text { em consonância com as normas de } \\
\text { procedimento da lei nacional. }\end{array}$ \\
\hline
\end{tabular}

Fonte: elaboração própria.

Uma das normas que a Corte faz menção no Caso 1 é o direito à liberdade pessoal, referida à possibilidade de todo ser humano de autodeterminar-se e escolher livremente as opções e circunstâncias que dá sentido a sua existência. Assim, o exercício de direito pelo 
conduto dos familiares encontra um acordo no referido artigo 7, dentro de um sistema de normas aplicáveis. Da mesma forma, no Caso 2, a Corte utiliza o artigo 12 da CDC referente à opinião da criança e sua participação nos assuntos que lhes afetem, incluso no processo judicial. Aqui a Corte entende a participação da criança dentro do processo como uma questão que fica ao arbítrio do julgador, quem deverá considerar o "superior interesse da criança”. Assim também, adquire relevância a representação da criança, seja através dos pais ou do estado.

\begin{abstract}
En consecuencia, el aplicador del derecho, sea en el ámbito administrativo o en el judicial, deberá tomar en consideración las condiciones específicas del menor de edad y su interés superior para acordar la participación de éste, según corresponda, en la determinación de sus derechos. En esta ponderación se procurará el mayor acceso del menor de edad, en la medida de lo posible, al examen de su propio caso. Asimismo, la Corte considera que las niñas y los niños deben ser informados de su derecho a ser escuchados directamente o por medio de un representante, si así lo desean. Al respecto, en casos en que se presenten conflictos de intereses entre la madre y el padre, es necesario que el estado garantice, en lo posible, que los intereses del menor de edad sean representados por alguien ajeno a dicho conflicto. (Caso 2, párr. 199).
\end{abstract}

No caso 3 se apresenta a mesma situação, mas são novamente colocadas como condicionantes para a participação, a idade e a maturidade da criança.

Igualmente, el Tribunal recuerda que el Comité de los Derechos del Niño ha señalado que el artículo 12 de la Convención sobre los Derechos del Niño no sólo establece el derecho de cada niño de expresar su opinión libremente en todos los asuntos que lo afectan, sino el artículo abarca también el subsiguiente derecho de que esas opiniones se tengan debidamente en cuenta, en función de la edad y madurez del niño. (Caso 3, párr. 230).

O último grupo de premissas relativas ao real, conforme Perelman e Olbrechts-Tyteca, é o das presunções. Diferentemente dos fatos e das verdades que se aceitam sem precisar de reforço algum e que outorgam segurança para obter a admissão do auditório, as presunções requerem de apoio adicional para sua aceitação. Entretanto, como os anteriores, pode subministrar as bases para a construção de uma convicção razoável e estas são válidas para o auditório universal com a mesma força que o acordo sobre os fatos comprovados e as verdades.

As presunções se encontram associadas ao que é normal e razoável, e também servem como ponto de partida para as argumentações. Aqui, o normal não se associa ao cálculo probabilístico, senão ao verossímil, ou seja, às convicções que surgem das experiências e o sentido comum que nos permitem orientar-nos na vida. Assim, “[...] o uso das presunções resulta em enunciados cuja verossimilhança não deriva de um calculo aplicado a dados de fato e não poderia derivar de semelhante cálculo, mesmo aperfeiçoado". (PERELMAN; OLBRECHTSTYTECA, 1989, p. 79). 
Portanto, distinguem-se as presunções do homem, que servem tanto como de ponto de partida quanto de chegada de um raciocínio; e as presunções legais, que são estabelecidas pela lei ou pela jurisprudência. Nestes três casos estudados foram identificados a presunção de indefenso e vulnerabilidade, que se encontram presentes como justificação da proteção especial para as crianças e adolescentes:

Quadro 4: Premissas relativas ao real. Presunções

\begin{tabular}{l|l|l|l} 
Presunções & Caso 1 & Caso 2 & Caso 3 \\
& Presunção de indefenso. & Presunção de indefenso. & Presunção de indefenso. \\
& $\begin{array}{l}\text { Presunção de } \\
\text { vulnerabilidade }\end{array}$ & $\begin{array}{l}\text { Presunção de } \\
\text { vulnerabilidade }\end{array}$ & $\begin{array}{l}\text { Presunção de } \\
\text { vulnerabilidade }\end{array}$ \\
\hline
\end{tabular}

Fonte: elaboração própria.

\section{Premissas relativas ao preferível}

Os valores, correspondem ao primeiro grupo de premissas que aspira à adesão de um auditório particular. Estas se encontram presentes em todas as argumentações, especialmente nos raciocínios do campo jurídico, político e filosófico, onde tais premissas interveem como base da argumentação através de recursos para comprometer o ouvinte a fazer certas eleições em lugar de outras, e de maneira que sejam aceitáveis e aprovadas pelos demais.

Perelman e Olbretchts-Tyteca fazem uma distinção entre valores abstratos e concretos. Os primeiros se referem a um determinado ser vivo, um grupo específico ou um objeto particular quando são examinados dentro de sua unicidade, por exemplo, a fidelidade ou a lealdade. Por outro lado, os segundos carecem desta determinação, como a justiça ou o bem.

Ora, os valores concretos sempre podem harmonizar-se: se o concreto existe, é por ser possível, é por realizar uma certa harmonia. Em contrapartida, os valores abstratos, levados ao extremo são inconciliáveis: é impossível conciliar no abstrato virtudes como a justiça e a caridade. (PERELMAN; OLBRECHTS-TYTECA, 2005, p. 8990).

Nas decisões estudadas é possível identificar valores abstratos e concretos que guardam relação com o exercício progressivo de direitos: 
Quadro 5: Premissas relativas ao preferível. Valores

\begin{tabular}{l|l|l|l} 
Valores & $\begin{array}{l}\text { Caso 1 } \\
\text { Proteção e cuidado especial } \\
\text { (concreto) }\end{array}$ & $\begin{array}{l}\text { Proteção e cuidado especial } \\
\text { (concreto) } \\
\text { Igualdade (abstrato) } \\
\begin{array}{l}\text { Liberdade de pensamento e } \\
\text { expressão (abstrato) }\end{array}\end{array}$ & $\begin{array}{l}\text { Participação } \\
\text { (concreto) }\end{array}$ \\
\hline
\end{tabular}

Nas considerações da Corte, os valores abstratos cumprem a função de justificar as mudanças no novo sistema de direitos para a infância, é por isso que os valores como a igualdade ou a liberdade adquirem grande relevância na construção jurídica e social dos novos sujeitos de direitos que agora possuem condição de pessoa humana. Por outro lado, os valores concretos ajudam a conceituar os novos direitos que foram adquiridos, seja ampliando ou reduzindo o exercício dos mesmos. Por exemplo, no Caso 1, a proteção e cuidados especiais que merecem as crianças, também alcança a proteção e cuidado de sua família:

\begin{abstract}
Los hechos probados afectaron también el derecho a la vida, previsto en el artículo 4.1 de la Convención, en perjuicio de María Macarena Gelman, en la medida que la separación de sus padres biológicos puso en riesgo la supervivencia y desarrollo de la niña, supervivencia y desarrollo que el estado debía garantizar, acorde a lo dispuesto en el artículo 19 de la Convención y en el artículo 6 de la Convención sobre Derechos del Niño, especialmente a través de la protección a la familia y la no injerencia ilegal o arbitraria en la vida familiar de los niños y niñas, pues la familia tiene un rol esencial en su desarrollo. (Caso 1, párr. 118).
\end{abstract}

Porém, quanto a valores concretos como a participação, relacionados ao direito de opinar e ser escutado, que já foram examinadas mais acima, se observam novamente limitantes relacionadas à idade e a maturidade da criança. Assim também, na prática argumentativa se produz a necessidade de hierarquizar os valores, isto pelo fato de que em muitos casos a afirmação simultânea de dois deles pode gerar incompatibilidade, obrigando a eleição. Esta eleição determinará a intensidade na adesão que se busca e, além disso, o valor que haverá de subordinar-se em benefício daquele que está privilegiado.

Quadro 6: Premissas relativas ao preferível. Hierarquias

\begin{tabular}{|c|c|c|c|}
\hline \multirow[t]{2}{*}{ Hierarquias } & Caso 1 & Caso 2 & Caso 3 \\
\hline & $\begin{array}{l}\text { Proteção e cuidados } \\
\text { especiais }>\text { Liberdade de } \\
\text { pensamento e expressão, } \\
\text { Igualdade. }\end{array}$ & $\begin{array}{l}\text { Proteção e cuidados } \\
\text { especiais }>\text { Liberdade de } \\
\text { pensamento e expressão, } \\
\text { Participação. }\end{array}$ & $\begin{array}{l}\text { Proteção e cuidados } \\
\text { especiais }>\text { Participação, } \\
\text { Igualdade. }\end{array}$ \\
\hline
\end{tabular}


Nas decisões analisadas vemos como o valor concreto relacionado à "proteção e cuidados especiais" adquire maior preponderância ante os demais valores como a "liberdade de pensamento e expressão", "igualdade" e "participação". Esta primazia da proteção e cuidados especiais pode encontrar fundamento nas presunções de vulnerabilidade e indefenso das crianças e adolescentes que foram vistas anteriormente, todavia, também pode ser um vestígio do antigo sistema de direitos que considerava as crianças e adolescentes como objetos de proteção.

O último grupo de premissas relativas ao preferível corresponde aos lugares. Perelman e Olbretchts-Tyteca denominam como lugares aquelas premissas de caráter muito geral das quais derivam os tópicos ou tratados dedicados ao raciocínio dialético, que servem para fundamentar valores, hierarquias, ou reforçar a intensidade da adesão. O uso dos lugares comuns na argumentação se produz em afirmações nas quais se demonstra preferência sobre o estável ante o instável, o duradouro ante o que não é, baseando-se nas premissas mais gerais que mantém superioridade do todo sobre a parte. Assim, isto se caracteriza conforme cada sociedade e época.

Para esse analise pode ser considerada a CDC, que é o instrumento jurídico internacional que tem marcado de maneira indiscutível uma transição sobre o enfoque de direitos para a infância na construção de novos sujeitos de direito. A CDC se orienta por quatro princípios fundamentais que constituem o marco reitor para cada um dos artigos que a conformam, sendo ao mesmo tempo a base jurídica mais importante para que os direitos das crianças e adolescentes se convertam em realidade e sejam exercidos pelos seus titulares. Desta maneira, se consagram os princípios de: não discriminação ${ }^{4}$; superior interesse da criança ${ }^{5}$; direito à vida, à supervivência e ao desenvolvimento ${ }^{6}$; e direito para participar ${ }^{7}$.

Nas decisões estudadas, se encontram presentes os mencionados quatro princípios reitores, entretanto, dois deles fazem uma alusão mais direta ao exercício progressivo de direitos: superior interesse da criança e direito para participar. Também resulta interessante que, na classificação dos lugares realizada por Perelman e Olbretchts-Tyteca, percebe-se especial atenção àqueles relacionados à essência e à pessoa. A primeira se refere ao fato que concede um valor superior aos indivíduos em qualidade de representantes, ou seja, se trata de uma

\footnotetext{
${ }^{4}$ Ver art. 2. Convenção Internacional sobre os Direitos da Criança.

${ }^{5}$ Ver art. 3. Convenção Internacional sobre os Direitos da Criança.

${ }^{6}$ Ver art. 6. Convenção Internacional sobre os Direitos da Criança.

${ }^{7}$ Ver art. 12. Convenção Internacional sobre os Direitos da Criança.
} 
comparação entre sujeitos concretos; e a segunda está mais relacionada com a concessão de um valor superior àquelas características das pessoas quanto a sua dignidade, sua capacidade e seus méritos. Ao respeito, pode-se dizer que o princípio de interesse superior da criança está mais relacionado à essência, enquanto o direito de participação parece se identificar melhor com a capacidade individual da pessoa.

Quadro 7: Premissas relativas ao preferível. Lugares

\begin{tabular}{l|l} 
Lugares & $\begin{array}{l}\text { Caso 1, Caso 2 e Caso } 3 \\
\text { Superior interesse da criança (essência) } \\
\text { Direito para participar (pessoa) }\end{array}$ \\
\hline
\end{tabular}

Fonte: elaboração própria.

\section{Considerações finais}

Para a análise das decisões da Corte IDH, foram agrupadas as premissas utilizadas pelo tribunal em duas categorias: uma relativa ao real, que compreende aos fatos, as verdades e as presunções; e outra relativa ao preferível, que abarca os valores, as hierarquias e os lugares do preferível. Neste sentido, foi possível constatar que a Corte IDH afirma como fatos relevantes, que as crianças e os adolescentes são sujeitos titulares de direitos humanos e que os mesmos exercem seus direitos de forma progressiva. Assim, é reafirmada a condição jurídica dos novos sujeitos de direitos e esses fatos são mencionados para justificar a participação dos mesmos dentro do processo judicial. Contudo, essa participação que é uma forma de exercício de direitos encontra-se limitada pela intervenção dos pais, os quais exercem este direito como representantes das crianças e adolescentes, especialmente na primeira infância.

Sobre as denominadas verdades, as decisões da Corte IDH fazem referência principalmente aos sistemas de normas que conformam a CDC e a Convenção Americana de Direitos Humanos, as quais gozam de credibilidade para a elaboração dos acordos devido à ampla aceitação demonstrada pelos estados signatários e sua incorporação nos ordenamentos jurídicos nacionais. Assim, nos casos analisados se identificam principalmente as normas relacionadas à liberdade e à participação, sendo a primeira, fruto de um logro histórico para a infância que sempre tinha estado submetida à vontade das pessoas adultas. Esta também representa uma característica na conquista de direitos que se diferencia de outros grupos excluídos como os negros, as mulheres ou os indígenas, devido a que as reivindicações e a militância não têm vindo direta e exclusivamente das crianças e dos adolescentes, senão de 
interlocutores adultos. Em relação à participação, são várias as normas que a consagram, mas as limitantes dentro das mesmas ocasionam um constante jogo de pesos e contrapesos, onde geralmente a idade e a maturidade determinam o resultado do conflito.

Essas limitações que determinam o peso da balança podem ser entendidas através das denominadas presunções, entre as quais se encontram a presunção de indefenso e vulnerabilidade. Sobre as origens destas presunções, elas podem estar no princípio do superior interesse da criança e nos fundamentos de proteção integral; ou talvez nos vestígios do antigo paradigma, onde as crianças eram consideradas objetos de proteção, o que também poderia significar um retrocesso neste novo sistema de direitos.

Em relação aos valores, a pesquisa demostra que os valores abstratos cumprem a função de justificar as mudanças no novo sistema de direitos da infância, enquanto que os valores concretos ajudam a conceituar os novos direitos que foram adquiridos. Entretanto, valores concretos relacionados à "proteção" e "cuidados especiais" adquirem maior preponderância ante valores como "liberdade de pensamento e expressão", "igualdade" e "participação". Assim, esta hierarquização de valores pode também estar relacionada às mencionadas presunções de vulnerabilidade e indefenso.

Finalmente, pode-se constatar que as premissas utilizadas pela Corte IDH em suas decisões sobre o exercício progressivo de direitos por parte de crianças e adolescentes se fundam no sistema normativo da CDC e a Convenção Americana de Direitos Humanos. Isto aparece de forma clara nos lugares utilizados pela Corte IDH, os quais correspondem aos quatro princípios fundamentais que indica a CDC. Neste sentido, ambos sistemas normativos consagram valores como a liberdade e a participação, apesar que esta última se veja limitada por valores concretos como a proteção, a qual se encontra estreitamente ligada a presunções de vulnerabilidade e indefenso, baseadas em condicionantes como a idade e a maturidade. Desta forma, embora que seja afirmada a condição jurídica de sujeitos titulares de direitos humanos para as crianças e os adolescentes, é importante destacar que o caminho a percorrer ainda é longo, porque apesar do reconhecimento jurídico, a conquista pelo exercício efetivo desses direitos é a seguinte etapa para lograr o acesso aos espaços de participação dentro da sociedade.

\section{Referências bibliográficas}

AGUILAR, Gonzalo. El principio del interés superior del niño y la Corte Interamericana de Derechos Humanos. Estudios Constitucionales, v. 6, n. 1, p. 223-247, 2008

$<$ http://www.redalyc.org/pdf/820/82060110.pdf> (28 set. 2018). 
ARCHARD, David; MACLEOD, Colin Murray (Ed.). The moral and political status of children. Oxford: Oxford University Press, 2002.

ARIÈS, Philippe. El niño y la vida familiar en el Antiguo Régimen. Madrid: Taurus, 1987.

ATIENZA, Manuel. Las razones del Derechos. Teoría de la Argumentación Jurídica. Ciudad de México: UNAM, 2005.

ÁVILA, Ramiro; CORREDORES, María. Derechos y Garantías de la Niñez y Adolescencia: hacia la consolidación de la doctrina de protección integral. Ecuador: V\&M Gráficas, 2010.

BARATTA, Alessandro. Democracia y derechos del niño. Justicia y Derechos del Niño, n. 9, p. 17-25, $2007<$ https://www.unicef.org/argentina/spanish/Justcia_y_derechos_9.pdf $>$ (28 set. 2018).

BELOFF, Mary. Los derechos del niño en el sistema interamericano. Buenos Aires: Editores del Puerto, 2009.

BELOFF, Mary. Fortalezas y debilidades del litigio estratégico para el fortalecimiento de los estándares internacionales y regionales de protección a la niñez en América Latina. Justicia y Derechos del Niño, n. 11, p. 55-81, $2009<$ http://unicef.cl/web/justicia-y-derechos-del-nino-n$11 />$.

BRASIL. Estatuto da criança e do adolescente: lei n. 8.069, de 13 de julho de 1990,e legislação correlata. Brasília: Câmara dos Deputados, Edições Câmara, 2010.

CORTE IDH. Caso Gelman Vs. Uruguay. Fondo y Reparaciones. Sentencia del 24 de febrero de 2011. Serie C No. 221.

CORTE IDH. Caso Atala Riffo y Niñas vs. Chile. Fondo, Reparaciones y Costas. Sentencia del 24 de febrero de 2012. Serie C No. 239.

CORTE IDH. Caso Furlán y Familiares Vs. Argentina. Fondo, Reparaciones y Costas. 
Sentencia del 31 de Agosto de 2012. Serie C No. 246.

GARCÍA MÉNDEZ, Emilio; CARRANZA, Elías. Infancia, adolescencia y control social en América Latina. Buenos Aires: Depalma, 1990.

GARCÍA MÉNDEZ, Emilio; CARRANZA, Elías. Del Revés al Derecho. La condición jurídica de la infancia en América Latina. Buenos Aires: Galerna, 1992.

GARCÍA MÉNDEZ, Emilio. Derecho de la infancia-adolescencia en América Latina: de la situación irregular a la protección integral. Santa Fe: Forum Pacis, 1994.

KUHN, Thomas S. La estructura de las Revoluciones Científicas. Ciudad de México: Fondo de Cultura Económica, 1971.

ORGANIZACIÓN DE LOS ESTADOS AMERICANOS. Convención Americana sobre Derechos Humanos. Buenos Aires: Ministerio de Justicia y Derechos Humanos de la Nación. Secretaría de Derechos Humanos y Pluralismo Cultural, 2016.

PERELMAN, Chaïm; OLBRECHTS-TYTECA, Lucie. Tratado da argumentação, a nova retórica. São Paulo: Martins Fontes, 2005.

UNICEF. Convención sobre los derechos del niño: 20 de noviembre de 1989. Madrid: UNICEF-Comité Español, 2006.

VIEHWEG, Theodor. Tópica y Jurisprudencia. Madrid: Taurus, 1964.

WITKER, Jorge. Cómo elaborar una tesis en Derecho. Pautas Metodológicas y Técnicas para el Estudiante o Investigador del Derecho. Madrid: Editorial Civitas, 1991. 


\title{
OS LIMITES DE REALIZAÇÃO DOS DIREITOS HUMANOS E SEU CONDICIONAMENTO À SOBERANIA DO ESTADO-NAÇÃO: REFLEXÕES SOBRE OS REFUGIADOS NA TEORIA DE HANNAH ARENDT
}

\author{
Ridivan Clairefont de Souza Mello Neto \\ Centro Universitário do Pará (CESUPA) \\ Loiane Prado Verbicaro \\ Centro Universitário do Pará (CESUPA)
}

\begin{abstract}
Resumo
O trabalho propõe-se a analisar os limites de realização dos Direitos Humanos e seu condicionamento à soberania do Estado-Nação. O ponto de partida da análise dar-se-á por pesquisa qualitativa de cunho bibliográfico, centrada no pensamento de Hannah Arendt e seus comentadores, objetivando refletir sobre a situação dos refugiados à luz dos Direitos Humanos e sua perspectiva paradoxal baseada na promessa de emancipação e, ao mesmo tempo, no condicionamento de realização aos instrumentos jurídico-políticos dos Estados-Nação. Para tanto, analisa-se a desnacionalização como instrumento de exclusão de minorias e a cidadania enquanto pressuposto para o exercício de direitos a ter direitos.
\end{abstract}

Palavras-Chave: Cidadania, Refugiados, Arendt, Nacionalidade, Direitos Humanos.

\section{Abstract/Resumen/Résumé}

The paper proposes to analyze the limits of the realization of Human Rights and its conditioning to the sovereignty of the Nation-State. The starting point of the analysis will be a qualitative bibliographical research, centered on the thinking of Hannah Arendt and her commentators, aiming to reflect on the refugee situation in the light of Human Rights and its paradoxical perspective based on the promise of emancipation and, at the same time, in the conditioning of realization to the juridical-political instruments of the Nation-States. Therefore, 
denationalization is analyzed as an instrument for the exclusion of minorities and citizenship as a prerequisite for the exercise of rights to have rights

Keywords/Palabras-claves/Mots-clés: Citizenship; Refugees; Arendt; Nationality; Human Rights.

\section{Introdução}

A discussão acerca das condições dos refugiados e demais formas de displaced persons (pessoas deslocadas) não é dos dias de hoje. Tal situação foi um desafio no século passado, especialmente em razão dos períodos de guerra e, nos dias atuais, revela-se mais do que de desafiadora.

A questão da Síria e outros conflitos contemporâneos fez ressurgir o debate acerca do tratamento dos refugiados no mundo, além do papel que os países devem desempenhar na busca por soluções com o fito de garantir a proteção e os direitos destas pessoas.

Alerta-se que as pessoas em geral abandonam seus lares em razão de conflitos, tais como o da Síria acima indicado. Ressalta-se que além dos deslocamentos para outros países há ainda o próprio deslocamento interno em que o indivíduo fica à margem de toda e qualquer proteção dentro de seu próprio Estado.

Apenas a título exemplificativo, de acordo com o Livro "Síria: da história à crise humanitária” (BENTES, NEVES e LOBATO, 2018, p. 59), aproximadamente 904.500 pessoas fizeram solicitação de assistência humanitária na Síria, sendo que quatro comboios de instituições humanitárias conseguiram, após intensas negociações com os grupos envolvidos nos conflitos, atender cerca de 167.500 pessoas.

O Alto Comissariado das Nações Unidas para os refugiados (ACNUR) por meio do Relatório "Global Trends: Forced Displacement in 2016" (2017) indicou que no mundo existiam cerca de 65,6 milhões de pessoas forçadas a deixar seu local de origem em razão de algum conflito, sendo que destes aproximadamente 22,5 milhões são refugiados.

O relatório destaca ainda que esta é a maior quantidade de refugiados já registrada em todos os tempos, sendo que 1 em cada 113 pessoas no mundo é forçada a se deslocar de seu lugar de origem. É possível constatar, por meio do relatório, que o número de refugiados cresceu aproximadamente cerca de $65 \%$ nos últimos cinco anos. 
No Brasil, de acordo com o relatório "Refúgio em números" (2016) da Secretaria Nacional de Justiça, órgão ligado ao Ministério da Justiça e Segurança Pública, aproximadamente 9.552 pessoas de 82 nacionalidades diferentes tiveram a condição de refugiado reconhecida.

O mesmo relatório indica que após o início do conflito na Síria aproximadamente 3.772 pessoas daquela nacionalidade solicitaram refúgio no Brasil. Além disso, em 2016, cerca de 3.375 venezuelanos realizaram também a mesma espécie de solicitação. Via de regra, estas pessoas precisam se deslocar de seus países de origem para outros locais do planeta em razão da total incompetência do seu Estado de nacionalidade em garantir seus direitos mínimos enquanto seres humanos.

Além do mais, constata-se que em geral os refugiados são provenientes de nações que possuem forte aspecto totalitário, despótico ou que estão em clima de guerra. Sendo assim, percebe-se que os Estados-Nação podem vir a ser os grandes responsáveis por tais deslocamentos forçados.

Em certa medida, os refugiados mantém suas respectivas nacionalidades, entretanto, não possuem a capacidade de retornar ao seu país de origem por diversos motivos, tais como motivos de raça, religião ou opiniões políticas, conforme definição apresentada pela Convenção relativa ao Estatuto dos Refugiados de 1951 (ONU, 1951).

Diante da crise e do desamparo humanitário, mais do que necessário o estudo da obra de Hannah Arendt que, em seu livro “Origens do Totalitarismo” (1989), entende que os refugiados são aqueles destituídos de qualquer direito, é dizer, são desprovidos do direito a ter direitos, uma vez que não são cidadãos do país de refúgio e nem mesmo de seu próprio país.

Registra-se que a situação não se limita ao fato de terem sido privados da liberdade, igualdade, propriedade e demais direitos. A calamidade decorre do fato de não pertencerem a qualquer comunidade e de não existirem mais leis que os protejam ou mesmo qualquer autoridade ou instituição capaz de ampará-los. Criou-se uma estrutura institucionalizada de completa privação de direitos em razão da ausência do direito a ter direitos e de reivindica-los. Trata-se da perda de uma comunidade disposta e capaz de garantir quaisquer direitos. Segundo Arendt, "o homem pode perder todos os chamados Direitos do Homem sem perder a sua qualidade essencial de homem, sua dignidade humana. Só a perda da própria comunidade é que o expulsa da humanidade". (ARENDT, 1989, p. 331).

Em realidade, constata-se o estabelecimento do que se pode denominar um Estado de Exceção permanente que tem como principal finalidade a realização da exclusão do indivíduo em razão do simples fato de ser apenas humano. Trata-se do exercício do chamado biopoder 
por parte do Estado nacional com o objetivo de selecionar aqueles que o próprio Estado entende como desejáveis e indesejáveis (CARNEIRO, 2018, p.59).

Carneiro (2018), tratando sobre os episódios dos imigrantes e refugiados, comenta a respeito da teoria de Agamben ao afirmar:

\begin{abstract}
Episódios que evidenciam a propriedade da tese de Giorgio Agamben acerca do biopoder exercido pelo Estado Nacional moderno sobre a população em seu território (...) um poder soberano que, nas primeiras décadas do século XX, desnaturaliza e desnacionaliza em massa seus cidadãos de acordo com a conveniência de seus interesses nacionais (CARNEIRO, 2018, p. 59).
\end{abstract}

Neste sentido, Carneiro (2018, p.59) alerta que este permanente Estado de Exceção atribui características de descartabilidade e "matabilidade", fazendo com que o imigrante possa vir a ser visto como uma espécie de homo sacer $^{l}$ da modernidade, principalmente em razão da atuação estatal neste processo de seleção e separação entre úteis e inúteis, desejáveis e indesejáveis.

Logo, parece que a utopia iluminista de sociedades fundadas na solidariedade e fraternidade foi dizimada. Vê-se uma ruptura civilizatória em que os valores democráticos de liberdade, dignidade, igualdade e Direitos Humanos submergem para a afirmação da democracia como eficiência e riqueza sem limites, em que prevalece o egoísmo e o absoluto individualismo. Ao lado dessa premissa, nota-se uma linha invisível que separa o humano e o sub-humano (ou inhumano). O patamar da humanidade e da definição do que é o humano acaba decorrendo de uma construção social, política, jurídica, com forte influência dos imperativos econômicos.

Diante de tal constatação, o trabalho propõe-se a refletir sobre a situação dos refugiados à luz dos Direitos Humanos e sua perspectiva paradoxal baseada na promessa de emancipação e, ao mesmo tempo, no condicionamento de sua realização aos instrumentos jurídico-políticos dos Estados-Nação.

O trabalho desenvolveu-se por intermédio de pesquisa bibliográfica de abordagem qualitativa, a partir do pensamento de Hannah Arendt sobre a função do Estado na possibilidade de esvaziamento de direitos de indivíduos em extrema vulnerabilidade; o processo de desnacionalização como instrumento de exclusão destas minorias; a necessidade de

\footnotetext{
${ }^{1}$ Agamben (2014) faz referência ao Homo sacer, que é uma figura enigmática do direito romano arcaico que se refere a uma dualidade paradoxal: ao portador de uma vida matável, mas insacrificável. É, ao mesmo tempo e de modo antagônico, o santo e o maldito. Reside aí uma ambivalência do sacro. Enquanto estabelece a sacralidade, autoriza também a sua morte.
} 
participação de todos os seres humanos em uma comunidade política e o papel da cidadania ou nacionalidade enquanto pressuposto para o exercício de direitos.

\section{O desvirtuamento do papel do estado-nação na proteção do direito dos refugiados sob a perspectiva de Hannah Arendt}

Hannah Arendt busca desenvolver seu pensamento a partir de sua experiência durante o nazismo na Alemanha. Em sua obra "As Origens do Totalitarismo” (1989) a autora analisa os principais motivos que levam à formação de um Estado Totalitário e as possíveis consequências para o desamparo aos Direitos Humanos. A autora defende que o Estado-Nação passa a não mais desempenhar seu papel fundamental de proteção de direitos e garantidor de estabilidade. Ao contrário, torna-se instrumento para a perpetuação de atrocidades.

Sobre isso comenta Turatto e Muller (2016, p. 413):

(...) o aspecto gritante entre os conceitos apresentados é a inapetência dos EstadosNação, em maior ou menor grau, em cumprir as razões pelas quais se justifica a existência dos próprios Estados - que, grosso modo, como uma comunidade política organizada que visa à constituição e manutenção do mundo humano o Estado garantiria a estabilidade ao domínio público através do consentimento daqueles que compõe essa comunidade (...).

Percebe-se que a ideia de Estado-Nação enquanto garantidor e protetor não se torna mais crível. Em realidade, o que se constata é que pode o Estado vir a tornar-se o grande violador e assaltante de direitos e garantias da pessoa.

Segundo Arendt (1989, p. 303):

As modernas condições de poder, que, exceto para os Estados gigantes, transformam a soberania nacional em pilhéria, junto com o advento do imperialismo e dos movimentos de unificação ética, foram fatores externos que solaparam a estabilidade do sistema europeu de Estados-nações.

O século XX, principalmente em sua primeira metade, fora marcado pelo avanço de movimentos de unificação ética que possuíam um cunho nacionalista e que, por isso, necessitavam de mecanismos para afastar as minorias de qualquer possibilidade de participação enquanto sujeitos de direitos ou ativistas da vida política. 
O mais importante mecanismo utilizado pelos Estados naquele período foi o que pode ser denominado de processo de desnacionalização. A desnacionalização, enquanto política de cunho totalitário, servia de meio para criar indivíduos totalmente desprovidos de direitos. Criar, em realidade, o que Aguiar (2012) define como “cadáveres vivos".

Trata-se, portanto, de grave instrumento que um Estado autoritário pode ter em mãos. Instrumento este que consiste em retirar de um indivíduo sua própria condição de sujeito de direitos. Inclusive, entende-se que o grau de totalitarismo de um Estado pode ser medido pela forma de uso deste mecanismo.

Tal comportamento estatal demonstra-se demasiadamente vil, visto que comprova que o Estado pode se utilizar de instrumentos legítimos, no caso a própria edição de leis, para tornar permanente situações que hodiernamente seriam vistas como ilegais. Trata-se, em verdade, do enraizamento de Estado de Exceção permanente.

\footnotetext{
Segundo Agamben, o estado de exceção evidencia-se quando determinadas medidas jurídicas não se coadunam com o sistema geral de direitos positivados, conferindo forma legal para uma exclusão discriminatória que não poderia ter forma legal. Com efeito, seus destinatários situam-se em uma "zona de indeterminação entre absolutismo e democracia", com status jurídico de semi-sujeitos de direito (CARNEIRO, 2018, p. 61).
}

Inclusive, destaca-se que Estado de Exceção se demonstra como a situação que melhor poderia definir a soberania do Estado-Nação na contemporaneidade. Ou seja, o papel de protetor que deveria ter sido desempenhado pelo Estado é mandado às favas e substituído por uma espécie de Estado inimigo que adota verdadeira técnica de governo que tem como finalidade excluir o refugiado de todo e qualquer papel dentro de uma comunidade política (CARNEIRO, 2018).

Frisa-se que para Arendt o ser humano é um ser político, que faz parte de uma comunidade política na qual se expressa principalmente a partir de três condições: labor; trabalho e ação. Trata-se da expressão da ideia de vita activa. Segundo Arendt em sua obra "A Condição Humana" (2010, p.15) "todos os aspectos da condição humana têm alguma relação com a política".

Portanto, a partir do momento que um indivíduo é afastado da sua condição de sujeito de direitos ou de sujeito político haveria total desprovimento de sua condição humana. O ser humano ficaria impedido de desempenhar as três atividades fundamentais que compõem a vita activa. 
A exclusão do indivíduo e a formação de minorias, por parte do Estado, é comentado por Stolcke (2002, p. 100):

O regime totalitário teve, antes de tudo, de "diferenciar" a minoria perseguida, negando-lhe sua condição de sujeito de direitos, privando-os de sua nacionalidade e convertendo-os, assim, em apátridas que, como a própria Arendt, tinham perdido seu Heimat.

Neste sentido, o Estado deixa de desempenhar seu principal papel e possibilita a criação de uma nova categoria de pessoas: os sem direitos. Estas pessoas, portanto, desprovidas de proteção de seu próprio Estado de origem iniciam a busca por refúgio em outros locais ou Estados em que possam ter o mínimo de proteção.

Esta acepção de que os refugiados e apátridas vivem à margem do sistema legal é tão enraizada que se constata que estes vivem às sombras de todo e qualquer sistema possível, onde quer que vão. Inclusive, Arendt (1989) destaca que na maioria das vezes um criminoso possui uma tutela estatal mais eficaz de seus direitos que um refugiado ou apátrida.

Os indésirables viam, portanto, a entrada para o mundo do crime como a saída para a garantia de alguma atenção por parte do Estado. Trata-se, em verdade, da possibilidade em transitar de uma anomalia não-reconhecida à posição de exceção protegida. Arendt é incisiva sobre isto (1989, p. 319):

O apátrida, sem direito à residência e sem o direito de trabalhar, tinha, naturalmente, de viver em constante transgressão à lei. Estava sujeito a ir para a cadeia sem jamais cometer um crime. Mais do que isso, toda a hierarquia de valores existentes nos países civilizados era invertida no seu caso. Uma vez que ele constituía a anomalia nãorevista na lei geral, era melhor que se convertesse na anomalia que ele previa: o criminoso.

Deve-se destacar que, conforme apresentado na introdução deste trabalho, para Arendt (1989) não há qualquer diferenciação entre apátrida e refugiado. Segundo ela, a partir do momento que um indivíduo necessita abandonar seu lar e deixa de possuir proteção de seu Estado de origem ele torna-se cidadão de lugar nenhum, vivendo à margem de qualquer tipo de sistema jurídico possível. Trata-se da percepção segundo a qual todo e qualquer Estado Constitucional e Democrático pode possuir seu campo permanente de exceção (CARNEIRO, 2018, p.60), tendo em vista que há a utilização da edição de leis com a finalidade de limitar a 
garantia de Direitos Humanos e a criação de verdadeiros "marginais" excepcionalmente permanentes.

Resta claro, portanto, que o Estado-Nação pode vir a ser utilizado como instrumento para o esvaziamento de direitos e criação de um indivíduo desprovido de qualquer condição política. CARNEIRO (2018, p. 63), tratando sobre Agamben, alerta que tal comportamento se refere justamente ao exercício do biopoder do Estado Nação sobre a vida nua daqueles que se encontram em seu território.

Trata-se, em verdade, da utilização do Estado para a destituição de Direitos Humanos. Arendt (1989, p.320) afirma que se um furto é meio para melhorar a posição legal de um ser humano é porque este, de fato, está destituído dos Direitos Humanos.

Entende-se que, a partir do momento que um não-sujeito está condenado a viver à margem da legalidade há uma espécie de quebra da percepção de igualdade que fundamenta a garantia e proteção de direitos.

Além do mais, a perda dos direitos nacionais para um indivíduo gera implicações direitas sobre a inviolabilidade de seus Direitos Humanos. Tal implicação deve-se principalmente em razão das considerações de que os Direitos dos Homens estão intimamente ligados à questão da emancipação nacional.

Em que pese a Declaração Universal dos Direitos do Homem ter trazido a pessoa para o centro da criação da lei, o que se constata é que ao longo dos anos houve a necessidade do estabelecimento de instituições que possibilitassem a proteção e garantia de tais direitos. Em razão disso, houve, segundo Arendt (1989), o condicionamento da proteção dos Direitos Humanos à soberania de um Estado-Nação que garantisse a proteção e efetividade destes direitos. Arendt (1989, p. 325) afirma que "Toda a questão dos direitos humanos foi associada à questão da emancipação nacional; somente a soberania emancipada do povo parecia capaz de assegurá-los - a soberania do povo a que o indivíduo pertencia”.

A consequência deste tipo de acepção que se formou é de que a proteção e garantia de Direitos Humanos pressupõe a necessidade do exercício da cidadania, bem como de um Estado que ofereça instrumentos para tal tipo de proteção. Portanto, a ideia de ser completamente emancipado enquanto "meramente" humano não se demonstra como uma realidade. Ao contrário, o ser humano não pode ser visto como ser plenamente emancipado para o exercício de direitos, mas sim necessita estar ligado à uma comunidade jurídico-política para tal exercício. 
Entretanto, o que se percebe é que além do Estado-Nação ter se transformado em mecanismo para cassação destes Direitos, viu-se uma espécie de "perplexidade dos direitos dos homens" ante a total ausência do caráter de "inalienabilidade" dos Direitos Humanos.

Sobre isso Arendt (1989, p. 325):

Os Direitos do Homem, afinal, haviam sido definidos como "inalienáveis" porque supunha serem independentes de todos os governos; mas sucedia que, no momento em que seres humanos deixavam de ter um governo próprio, não restava nenhuma autoridade para protegê-lo e nenhuma instituição disposta a garanti-los.

Restou-se, em realidade, demonstrado que o que havia até o momento do início da crise do Estado-Nação era uma espécie de defesa abstrata de direitos que não teve o condão de impedir o avanço de uma forma de governo autoritário que não permitisse o esvaziamento de direitos.

Diz Aguiar (2012, p. 146):

\begin{abstract}
Nesse item, Arendt disserta sobre a insuficiência dos Direitos Humanos, pois a vida defendida na Declaração Universal dos Direitos Humanos, conjugada com a ideia de nação, é abstrata, natural e biológica. A defesa abstrata da vida foi incapaz de barrar o mal radical, a descartabilidade dos homens como seres capazes de pensar e agir. Esse processo inicia com a desnacionalização, gera um contingente enorme de refugiados e se transforma no leitmotiv do domínio total e do extermínio.
\end{abstract}

Resta demonstrada a falibilidade dos Direitos Humanos em proteger o ser humano quando este encontra-se desprovido de toda e qualquer característica política. Por isso, Hannah Arendt possui extrema preocupação com o aspecto político da efetividade dos Direitos Humanos.

Sobre isto comenta Pinheiro e De Souza (2014, p.157):

Os direitos humanos, universalmente consagrados e juridicamente positivados nas declarações, não se mostram eficazes na proteção de homens necessitados de seu amparo jurídico político, evidenciando toda a sua fragilidade diante de seu primeiro grande embate fático- a situação dos apátridas que ficaram à mercê da sorte e da violência. A partir desta constatação histórica, Arendt vai pensar a natureza política de tais direitos e a possibilidade de sua efetivação em outras bases.

Ou seja, a ideia de emancipação do indivíduo enquanto detentor de Direitos Humanos pelo simples fato de ser humano demonstrou-se falha na perspectiva arendtiana. Isso porque os Direitos Humanos efetivamente positivados foram ineficazes em seu embate, justificando a 
necessidade em rediscutir o papel político da pessoa dentro do sistema para ter seus direitos garantidos.

Logo, além do próprio Estado se tornar solapador dos direitos, constata-se que os regimes totalitários se aproveitaram de uma espécie de falha na teoria de proteção dos Direitos Humanos com o fito de garantir que nenhum direito efetivamente alcançasse a pessoa, tendo em vista que neste primeiro momento o que se vislumbra é a total abstração dos mecanismos de proteção dos Direitos Humanos.

Neste sentido, é cabal a conclusão de que simplesmente ser um ser humano não seria requisito suficiente para gozar de Direitos Humanos. Ao contrário, faz-se necessária a pertença à uma comunidade política, pois viver à margem do exercício da cidadania seria impedir a vida plena.

Constata-se que, de fato, há verdadeiro paradoxo na proteção dos Direitos Humanos de refugiados. A ideia de direitos dos homens, existentes de maneira incondicional, baseados na singela existência do homem enquanto tal viu-se arruinada diante do desamparo dos refugiados e apátridas que perderam toda proteção jurídico-política do Estado-Nação, exceto o puro fato da sua pura existência. Sobre isso Arendt (1989, p.335-336):

O paradoxo da perda dos direitos humanos é que essa perda coincide com o instante em que a pessoa se torna um ser humano em geral- sem uma profissão, sem uma cidadania, sem uma opinião, sem uma ação pela qual se identifique e se especifiquee diferente em geral, representando nada além da sua individualidade absoluta e singular, que, privada da expressão e da ação sobre um mundo comum, perde todo o seu significado.

Arendt em sua obra "Nós, os Refugiados" (2013) alerta que haveria, na realidade, verdadeiro perigo em sermos apenas humanos. Afirma Arendt (2013, p.19):

\footnotetext{
Se tivéssemos que começar por dizer a verdade de que não somos nada para além de judeus, tal significaria que nos expomos ao destino dos seres humanos que, não protegidos por qualquer lei ou convenção política específica, não são mais do que seres humanos. Dificilmente consigo imaginar uma atitude mais perigosa, desde que vivemos realmente num mundo no qual seres humanos enquanto tais deixaram de existir há já algum tempo.
}

Tal perigo, conforme já alertado acima, se deve em razão da necessidade de a proteção se dar por meio da garantia pelos mecanismos estatais que se legitimariam na soberania popular 
da qual a pessoa supostamente faria parte. Entretanto, o problema revela-se justamente no momento em que o Estado-Nação falha nesta proteção e torna-se vilão e usurpador de direitos. Aguiar (2012) alega que Arendt entende ser o principal objetivo dos regimes totalitários tornar os homens meros animais laborans. Afirma Aguiar (2012, p. 152):

O desenraizamento, a desnacionalização e o fato de não pertencer ao mundo comum, isto é, à superficialidade das massas, tornam os homens meros animais laborans, cuja vida se resume à atividade de mero ser natural, visando à própria reprodução como ser vivo.

Desta feita, percebe-se que os regimes de cunho totalitário encontraram no EstadoNação e na "perplexidade do direito dos homens" a possibilidade de neutralizar aqueles cidadãos que consideravam indesejáveis e torná-los verdadeiros zumbis jurídicos.

Estes zumbis jurídicos são formados, como acima apresentado, por meio do processo de desnacionalização que cria um conjunto de apátridas e/ou refugiados que não possuem qualquer capacidade de ter seus direitos garantidos, tendo em vista que haveria uma imprescindibilidade da cidadania para o exercício de direitos.

Ora, a partir do momento que o Estado passa de garantidor a vilão o que se tem nesta seara é justamente a possibilidade de expulsão do ser humano indesejado de toda e qualquer comunidade política.

Percebe-se que para Arendt (1989) mais importante do que a existência de Direitos Humanos e de um Estado-Nação garantidor deste direito é a garantia de identidade e cidadania ao indivíduo como forma de integrá-lo à comunidade. Sendo assim, os apátridas e refugiados, enquanto pessoas indesejadas, passam a viver paralelamente à comunidade das nações sob a tutela de "Tratados de Minorias" que ao invés de integrá-los e concede-lhes uma nova identidade, faziam com que se tornassem minoria excluída tutelada sob documentos ineficazes. Segundo Arendt (1989, p.327):

Ninguém se apercebia de que a humanidade, concebida durante tanto tempo à imagem de uma família das nações, havia alcançado o estágio em que a pessoa expulsa de uma dessas comunidades rigidamente organizadas e fechadas via-se expulsa de toda a família das nações.

A limitação do direito de nacionalidade e da cidadania fora utilizada pelos governos dos Estados-Nação para transformar pessoas em não-pessoas e negá-las o direito a ter direitos. 
Trata-se, portanto, da utilização do Estado-Nação para esvaziar o patrimônio jurídico dos indesejados e expulsá-los da humanidade.

\section{O ir além: a necessidade de reincorporação dos refugiados à comunidade humana para efetividade de seus direitos. a concepção de cidadania em Hannah Arendt}

Como demonstrado, o que se constata é que para Arendt é imprescindível que o ser humano participe e seja integrante de uma comunidade política. Inclusive, em sua obra "Nós, os Refugiados" (2013), Arendt afirma ter a impressão de que o povo judeu, após todos os acontecimentos na Alemanha, buscou uma nova identidade para tentar integrar-se à uma comunidade e reposicionar-se como membro da humanidade e integrante de um sistema de proteção de direitos, inclusive o direito de ser judeu.

Sobre este ponto comenta Arendt (2013, p. 16):

\footnotetext{
Muitos poucos indivíduos têm força para conservar a sua própria integridade se o seu estatuto social, político e legal estiver completamente confuso. Faltando a coragem para lutar pelo nosso estatuto social e legal, decidimos, em vez disso, tantos de nós, tentar mudar de identidade.
}

Se partirmos para uma análise ampla, para além da situação judaica, constatamos que todo e qualquer refugiado busca reintegrar-se à uma comunidade política com o fito de garantir proteção e a possibilidade do exercício de direitos.

Arendt é enfática sobre este ponto (2013, p. 18):

\footnotetext{
Somos fascinados por qualquer nova nacionalidade do mesmo modo como as mulheres um pouco fortes se deliciam com qualquer vestido que prometa dar-lhe a cintura desejada. Mas, ela também gosta de novos vestidos desde que acredite nas suas qualidades milagrosas e deitará fora tão rápido quanto descobrir que ele não lhe muda a estatura, ou, de resto, o seu estatuto.
}

O que resta demonstrado é que os refugiados, na busca pela proteção de seus direitos, sempre estão em busca de uma nacionalidade, no sentido de ter alguma espécie de vínculo jurídico com determinado Estado para garantir o mínimo de proteção. 
Chega a parecer até certo ponto paradoxal a afirmação da autora de que o Estado seria vilão e solapador de direitos e ao mesmo tempo a afirmação de que se faz necessária a existência de um vínculo jurídico-político para que se possa obter direitos.

Entretanto, a única saída que, levando em consideração todos os acontecimentos ocorridos, se verificava era a necessidade de reintegração do ser humano à comunidade política ante a exigência dos estatutos e documentos de Direitos Humanos terem como pressuposto o exercício destes direitos.

Sobre este ponto comenta Turatto e Muller (2016, p. 414):

A cidadania será o elemento que concederá aos indivíduos o lugar no mundo e, consequentemente o direito de participar da vida política; aliás, somente enquanto um nacional, que poderá reclamar a proteção da Declaração Universal dos Direitos Humanos. Tão somente enquanto participante de um Estado - cidadão - a propalada dignidade humana poderá ser construída.

Inclusive, é interessante a conclusão que Turatto e Muller (2016) chegam a respeito do posicionamento de Arendt. Segundo as autoras, Arendt, em “Origens do Totalitarismo”, não possui uma concepção universalista de Direitos Humanos. Isso porque o alcance dos Direitos Humanos aos refugiados, segundo sua análise, somente pode ser alcançado por meio da concepção de cidadania e, portanto, por intermédio de vínculo com algum Estado, mesmo que este último tenha sido o grande vilão das pessoas de seu tempo.

$\mathrm{Na}$ obra de Arendt é clara a ideia de que houve verdadeira falha do ideal iluminista de emancipação do ser humano. Ao contrário, estabeleceu-se a necessidade de integração de uma comunidade com fito de garantir a efetividade dos Direitos Humanos. Logo, é clara a percepção de Arendt não adota um posicionamento universalista de Direitos Humanos.

Sobre isto afirma PEREIRA (2014, p.66):

Tanto Arendt quanto Agamben criticam, cada um ao seu modo, o caráter supostamente universal dos direitos humanos. A crítica de Arendt diz que a cidadania é algo fundamental para a garantia dos direitos humanos e que essa é uma condição que inviabiliza o acesso dos grupos de apátridas e dos refugiados aos direitos básicos que sempre foram considerados universais pela tradição jusnaturalista (...).

Esta busca pela necessidade de reintegração dos refugiados à comunidade humana, em especial pela necessidade de um vínculo jurídico com determinado ente estatal, se dá principalmente em razão da perplexidade que os atos cometidos contra o povo judeu causou. 
Comentando toda situação vivida por seu povo afirma Arendt (2013, p. 9):

Aparentemente ninguém quer saber que a história contemporânea criou um novo tipo de seres humanos - o tipo dos que são postos em campos de concentração pelos seus inimigos e nos campos de internamento pelos seus amigos.

Trata-se de uma situação de exclusão, marginalização e desprestígio. É a concretização da situação de "pária". Este sentimento talvez fosse ainda reforçado pelo modo como a comunidade internacional regulava, e talvez até nos dias de hoje ainda regule, o tratamento dado aos refugiados.

Destaca-se que para designar o status dos refugiados, Arendt utiliza-se de expressões como: "refugo da terra", além de que essas pessoas viam-se fora "de toda a família das nações" (ARENDT,1989). Tais expressões refletem a situação de refugiados tanto na época em que a autora viveu quanto nos dias atuais.

Arendt (1989) destaca que os refugiados viam-se subordinados aos chamados "Tratados de Minorias". Esses tratados foram estabelecidos de tal forma que colocaram os refugiados na Europa em uma espécie de limbo entre a nacionalidade e o exercício da cidadania.

Em realidade, segundo Arendt (1989), estes tratados não foram firmados no sentido de garantir Direitos Humanos aos refugiados. Ao contrário, a função era justamente a de buscar solução paliativa, tendo em vista que havia uma concepção formada nos Estados-Nação de que as minorias precisariam ser eliminadas.

Diz Arendt (1989, p.306):

Se os Tratados das Minorias tivessem sido concebidos como algo mais do que mero remédio temporário para uma situação caótica, sua restrição implícita à soberania nacional teria afetado a própria soberania nacional das potências europeias mais antigas. Os representantes das grandes nações sabiam demasiado bem que as minorias existentes num Estado-nação deviam, mais cedo ou mais tarde, ser assimiladas ou liquidadas.

Ora, o que se percebe é que a existência destes Tratados, que aparentemente buscavam proteger as minorias refugiadas, não restava suficiente, visto que além de serem documentos ineficazes não realizavam a total reintegração dos refugiados à comunidade humana.

Isso se deve principalmente ao fato de que tais documentos ainda assim precisavam ser reconhecidos pelo Estado-Nação para serem aplicados às minorias e refugiados que realizassem tal demanda. 
Comenta Turatto e Muller (2016, p.414-415):

Parece-nos que a situação descrita por Arendt não é muito diferente daquela em que os refugiados se encontram atualmente, uma vez que eles somente podem recorrer a declarações, convenções, pactos internacionais, cuja eficácia depende de aceitação e cumprimento por parte dos Estados-Nação onde as pessoas solicitam refúgio.

Sendo assim, estes "Tratados de Minorias", que teriam o objetivo de estabelecer garantias, só reforçam a acepção de que a garantia de direitos perpassa pela necessidade do estabelecimento de cidadania para os refugiados.

Sobre esta situação manifesta-se Arendt (1989, p.308):

Os Tratados das Minorias diziam em linguagem clara aquilo que até então era apenas implícito no sistema operante dos Estados-Nações, isto é, que somente os "nacionais" podiam ser cidadãos, somente as pessoas da mesma origem nacional podiam gozar de toda proteção das instituições legais (...).

Pelas razões expostas é que, na perspectiva de Arendt, faz-se necessária a reincorporação da pessoa à comunidade humana. Tal necessidade desnuda-se principalmente em razão da insuficiência da garantia de Direitos Humanos aos refugiados fora da estrutura de um Estado-Nação.

Sendo assim, somente a reintegração da pessoa à comunidade política poderia permitir que esta se tornasse cidadã novamente. Isso se deve principalmente em razão da insuficiência dos Direitos Humanos em, ainda que positivados e previstos em documentos, proteger a pessoa pelo simples fato de ser pessoa e não um ser político.

Logo, apesar de para Arendt o Estado ser o principal vilão diante possibilidade de se tornar vampiro de direitos de minorias e refugiados, somente através do resgate da identidade de um vínculo jurídico com uma comunidade política é que haverá a possibilidade do exercício de direitos e garantias.

A concepção de Arendt sobre a cidadania perpassa, portanto, pela necessidade de os seres humanos, neste caso refugiados, fazerem parte de uma comunidade política em razão da proteção e garantia de direitos. Trate-se, portanto, de uma concepção de cidadania voltada ao direito a ter direitos. 


\section{Conclusão}

O Estado-Nação pode plenamente tornar-se instrumento para o esvaziamento de Direitos Humanos dos refugiados. Isso se deve, segundo Arendt (1989), principalmente em razão da possibilidade de o Estado utilizar-se de sua estrutura e burocracia para esta finalidade.

O principal instrumento empregado pelo Estado se dá por meio da desnacionalização. Tal processo possibilitou que os refugiados se tornassem verdadeiros apátridas, ou seja, desprovidos de toda e qualquer proteção, vivendo à margem de qualquer sistema jurídicopolítico.

Segundo Arendt (2013) criou-se, em verdade, uma nova categoria de seres humanos. Trata-se dos tidos como insésirables, levados aos campos de concentração por seus inimigos e aos campos de internamento pelos amigos (ARENDT, 2013).

Nesse sentido, os refugiados tornaram-se verdadeiras párias que transitavam entre o limbo jurídico em que viviam e o esquecimento de sua cidadania. Isso se deve em razão da insuficiência dos próprios Tratados que se estabeleceram com a finalidade de suposta proteção.

Tais tratados, chamados por Arendt (1989) de Tratados de Minorias, ao invés de fornecer proteção, foram utilizados pelos Estados-Nação com o objetivo de criar minorias para que, em seguida, pudesse expulsá-las de seu território.

Sendo assim, esperava-se que para proteção e garantia dos direitos destes apátridas, houvesse a possibilidade de aplicação de direitos tidos como inalienáveis. Entretanto, houve uma espécie de incapacidade dos direitos do homem serem garantidos aos refugiados e apátridas. Tal situação, segundo Arendt (1989), é consequência de uma espécie de "perplexidade dos direitos dos homens".

Nesse sentido, quando o ser humano perde seu status político, tornava-se vulnerável e à mercê do desamparo. Isso se dava em razão da constatação de que os Direitos Humanos necessitavam de uma espécie de estrutura estatal com a finalidade de protegê-los. Sendo assim, a ideia de homem enquanto ser completamente emancipado não se sustentava, tendo em vista que o indivíduo seria incorporado ao povo e a situação de proteção de direitos humanos passaria a estar associada à emancipação nacional e não do ser humano (ARENDT, 1989).

Sendo assim, uma das conclusões possíveis é a de que os Direitos Humanos passaram a se tornar inexequíveis para aqueles que foram destituídos de sua cidadania, revelando-se a perplexidade diante de seu desamparo nas circunstâncias mais prementes e necessárias. Ora, os Estados-Nação que deveriam ter a função de proteger e garantir tais direitos tornaram-se, em 
realidade, verdadeiros usurpadores destes por meio da negação da cidadania e nacionalidade dos indesejados.

É o Estado-Nação sendo utilizado como verdadeiro instrumento para o esvaziamento de direitos. Muito além das retiradas de direitos, trata-se da expulsão da pessoa de toda a família das nações (ARENDT, 1989). É, de fato, a expulsão da pessoa da própria humanidade. Inclusive, neste ponto, Arendt (2013) alerta que uma das grandes lições que se pode retirar das experiências de sua época é o risco de o indivíduo ser apenas humano. Ser somente humano torna-se perigoso justamente em razão do fato de que para o exercício de todo e qualquer direito haveria a necessidade da existência de vínculo político com determinada comunidade.

Inclusive Turatto (2016) alerta que uma das lições apresentadas por Arendt é justamente o fato de que a privação da cidadania, da proteção legal e da condição política torna a fala da pessoa irrelevante, perdendo qualquer possibilidade de participar da vida pública.

Em razão disso, é que para Arendt (1989) o principal ponto para a garantia de direitos aos refugiados, por mais paradoxal que possa parecer, é a necessidade de retomada da cidadania, ou seja, do vínculo político com determinada comunidade. Tal perspectiva parte da análise de que, em que pese o Estado-Nação ter entrado em declínio ao se tornar instrumento limitador de direitos dos refugiados e apátridas, há a obrigatoriedade de garantir que cada indivíduo possa ter protegido seu direito em participar de uma comunidade política.

Somente a partir da garantia de voz política é que a pessoa passa a ter a possibilidade de proteção de direitos, tendo em vista que a garantia de Direitos Humanos pressupõe a existência do vínculo de cidadania para a sua eficácia.

Apresenta-se o que Stolcke (2002) afirma ser uma proposta de cultura cívica do público. Uma necessidade de reversão do processo de despolitização que os Estados-Nação totalitários haviam concretizado em face daqueles que desejavam tornar minorias.

Neste sentido, a perspectiva de Arendt (1989) acerca da cidadania se dá por meio da necessidade em garantir o direito a ter direitos. Tal expressão se traduz, portanto, na demanda de reintegrar os refugiados às comunidades para que assim possam ter voz política na luta pela proteção e garantia de seus direitos.

Logo, mesmo o Estado-Nação tendo incontáveis chances de ser violador de direitos, somente através da participação do indivíduo de uma comunidade política desta espécie pode garantir que o ser humano torne-se mais que humano, visto que ser apenas humano restou demonstrado insuficiente. Aí reside a própria ideia dos limites e do potencial de emancipação dos Direitos Humanos. 
É necessário, portanto, reverter a expulsão da humanidade sofrida pelos refugiados por meio da garantia do direito a ter direitos. Mais do que ajuda humanitária ou social, o refugiado, para Arendt (1989), precisa ser reincorporado à humanidade através da sua participação política. Para Arendt (1989), trata-se ser mais do que ser um ser humano. Trata-se de ser cidadão.

\section{Referências bibliográficas}

AGAMBEN, Giorgio. Homo Sacer. O poder soberano e a vida nua I. Belo Horizonte: Editora UFMG, 2014.

. Estado de Exceção. São Paulo: Boitempo, 2004.

AGUIAR, Odílio Alves. A recepção biopolítica da obra de Hannah Arendt. Caxias do Sul: Conjectura, v.17, n.1, p.139-158, 2012. Disponível em: file://Users/Liliani/Downloads/15305174-1-PB.pdf

ARENDT, Hannah. A condição humana. Rio de Janeiro: Forense Universitária, 2010. . As origens do totalitarismo. São Paulo: Companhia das Letras, 1989. . Nós, os Refugiados. Covilhã: LusoSofiaPress, 2013. Disponível em: http://www.lusosofia.net/textos/20131214-hannah_arendt_nos_os_refugiados.pdf

BENTES, Natália Mascarenhas Simões; NEVES, Rafaela Teixeira Sena; LOBATO, Luísa Cruz (org.). Síria: da história à crise humanitária. Porto Alegre: Editora Fi, 2018. Disponível em: https://www.editorafi.org/274siria

\section{CARNEIRO, Cynthia Soares. Políticas Migratórias no Brasil e a Instituição dos} "Indesejados": A Construção Histórica de um Estado de Exceção para Estrangeiros. In: Revista Opinião Jurídica, Fortaleza, ano 16, n. 22, p.56-85, jan./jun., 2018. Disponível em: http://periodicos.unichristus.edu.br/index.php/opiniaojuridica/article/view/1728/620 
CONVENÇÃO RELATIVA AO ESTATUTO DOS REFUGIADOS DE 1951, de 28 de Julho de 1951. Disponível em:

http://www.acnur.org/fileadmin/scripts/doc.php?file=fileadmin/Documentos/portugues/BDL/ Convencao_relativa_ao_Estatuto_dos_Refugiados\&view.

CORREAA, Murilo Duarte Costa; SOUZA, Karoline Coelho de Andrade. Os direitos humanos que vêm: notas sobre política, inoperosidade e desativação. In: Revista Lugar Comum n. 48, 2016.

GIACOIA JÚNIOR, Oswaldo; RAMIRO, Caio; RICCI, Luiz Antônio (org.).

Responsabilidade e futuro: bioética, biopolítica, biopoder e os desafios para reflexão e ação. São Paulo: LiberArs, 2015.

HUNT, Lynn. A invenção dos direitos humanos. São Paulo: Companhia das Letras, 2009.

LEAL, Ana Christina; DIAS, Bárbara; VERBICARO, Loiane (org.). Normalização, Poder e Direito. Salvador: Juspodium, 2017.

NEGRI, Antonio. Biocapitalismo. São Paulo: Iluminuras, 2015.

PASSOS, Izabel C. Friche. (org). Poder, normalização e violência: incursões foucaultianas para a atualidade. Belo Horizonte: Autêntica Editora, 2013.

PEREIRA, Ana Paula Silva. A crítica de Hannah Arendt à universalidade vazia dos Direitos Humanos: o caso do "refugo da terra". 2014. Dissertação (Mestrado em Filosofia)- Centro de Ciências Humanas, Letras e Artes, Universidade Federal da Paraíba. Disponível em: http://tede.biblioteca.ufpb.br/bitstream/tede/5667/1/arquivototal.pdf

PINHEIRO, Flávio Maria Leite; DE SOUZA, Ana Paula Marque. A questão das minorias étnicas, refugiados e apátridas em face do totalitarismo na visão de Hannah Arendt. In: Direito Internacional e Direitos Humanos III [Recurso Eletrônico on-line] organização CONPEDI/UFPB; Coordenadores: Alessandra Correia Lima Macedo Franca, Eugenia Cristina Nilsen Ribeiro Barza. Florianópolis: 2014. Disponível em: http://publicadireito.com.br/publicacao/ufpb/livro.php?gt=259 
SECRETARIA NACIONAL DE JUSTIÇA, MINISTÉRIO DA JUSTIÇA E SEGURANÇA PÚBLICA. REFÚGIO EM NÚMEROS. Disponível em:

http://www.justica.gov.br/news/brasil-tem-aumento-de-12-no-numero-de-refugiados-em2016/20062017_refugio-em-numeros-2010-2016.pdf

SLOTERDIJK, Peter. No mesmo barco. Ensaio sobre a hiperpolítica. São Paulo: Estação Liberdade, 1999.

STOLCKE, Verena. Pluralizar o universal: guerra e paz na obra de Hannah Arendt. Rio de Janeiro: Mana, v.8, n.1, p. 93-112, 2002. Disponível em: http://www.scielo.br/ pdf/mana/v8n1/9642.pdf

TURATTO, Ana Carolina; MULLER, Maria Cristina. Os Refugiados: Considerações Arendtianas e a atual experiência. In: XI Seminário de Pesquisa em Ciências HumanasSEPECH Humanidades, Estado e Desafios Didático-Científicos (Londrina, 27 a 29 de Julho de 2016), p. 408-419. Disponível em: http://pdf.blucher.com.br.s3-sa-east1.amazonaws.com/socialsciencesproceedings/xi-sepech/gt4_117.pdf

UNHCR - United Nations High Commisioner for Refugees. Disponível em: http://www.unhcr.org/540854f49.pdf.

UNITED NATIONS HIGH COMMISSIONER FOR REFUGEES (UNHCR). Global Trends: Forced Displacement in 2016. Disponível em:

http://www.unhcr.org/statistics/unhcrstats/5943e8a34/global-trends-forced-displacement2016.html

VILLEY, Michel. O direito e os direitos humanos. São Paulo: Martins Fontes, 2007. 


\title{
PESSOAS COM DEFICIÊNCIA: DA SEGREGAÇÃO À PROTEÇÃO INTERNACIONAL
}

\author{
Adriana Fasolo Pilati Scheleder \\ Universidade de Passo Fundo-UPF \\ Janaína de Oliveira \\ Universidade de Passo Fundo - UPF
}

\begin{abstract}
Resumo
O presente artigo científico tem como objetivo avaliar o tratamento conferido pelo Estado às pessoas com deficiência em distintas épocas. Também, busca-se verificar a importância e as consequências da evolução dessa abordagem. Através do método dedutivo e da pesquisa bibliográfica em livros, legislação e documentos internacionais, acompanha-se uma nova concepção em defesa dos direitos das pessoas com deficiência e consequentemente a proteção de sua dignidade, evoluindo de um modelo de total segregação para um contexto protetivo dos direitos humanos em nível mundial, objetivando a inclusão, igualdade e preservação da dignidade humana.
\end{abstract}

Palavras-chave: Acessibilidade, Dignidade da pessoa humana, Direitos fundamentais, Direitos humanos, Pessoas com deficiência.

\begin{abstract}
Resumen/Résumé
This article has as objective to evaluate the treatment given by the State to persons with disabilities in different eras. It also seeks to verify the importance and consequences of the evolution of this approach. Through the deductive method and the bibliographical research in books, legislation and international documents, attached is a new concept in defense of the rights of persons with disabilities and consequently the protection of their dignity, evolving from a model of total separation for a protective context of human rights at world level, aiming at the inclusion, equality and preservation of human dignity.
\end{abstract}

Keywords/Palabras-claves/Mots-clés: Accessibility. The dignity of the human person. Fundamental Rights. Human Rights. People with disabilities. 


\section{Introdução}

O presente artigo científico tem como escopo refletir a situação vivenciada pelas pessoas com deficiência em distintas fases históricas frente as políticas aplicadas pelo Estado. Tal conjuntura, partiu de períodos repletos de atos bárbaros que visavam repelir a participação e a convivência dessas pessoas no meio social.

Por consequência a problemática reside em verificar a evolução desse tratamento conferido pelo Estado e as políticas que vieram a ser adotadas para garantia de direitos e igualdade de todos. O objetivo desse enredo fundamenta-se na avaliação do avanço conquistado ao longo das últimas décadas pelas pessoas com deficiência, e maneira como a visão protetiva norteadora das atividades do Estado, passou a incorporar o debate em nível internacional, despertando a consciência de todos da necessidade de se salvaguardar os direitos humanos das pessoas, independentemente de suas particularidades.

Dessa forma, através do método indutivo e de pesquisa bibliográfica, inicia-se o artigo pelo retrospecto da forma como as pessoas com deficiência foram recepcionadas na sociedade, perpassando pelo estágio da total segregação, evoluindo na construção de instrumentos protetivos em nível internacional, e por fim, observando de que maneira o ordenamento jurídico brasileiro opera nessa temática de forma a garantir a dignidade da pessoa humana.

\section{Breve histórico da segregação das pessoas com deficiência}

Desde os primórdios da humanidade as pessoas com deficiência necessitaram lutar constantemente pelo seu direito à vida e consequentemente por sua participação e convivência de forma igualitária na sociedade. Por longos anos, em diferentes Estados e épocas, todos aqueles que possuíam qualquer tipo de deficiência ou não se enquadravam nos padrões estabelecidos pela sociedade, como correto ou adequado, eram terrivelmente afastados do convívio social.

Cabe ressaltar que deficiência, seja ela física ou intelectual, sempre existiu, foi a forma como as pessoas com deficiência foram tratadas pelas sociedades que se alterou. Isto é, a maneira como o Estado procedeu em suas políticas frente a essas pessoas.

Importante referir que as pessoas com deficiência, perpassaram estágios de exclusão social, e de outros mais brutais ainda, como a condenação à morte daqueles que não possuíam 
características físicas ou intelectuais de acordo com o considerado "normal" pela sociedade de cada época.

Rememorando períodos já transcorridos, se tem informações de que na antiguidade clássica, o monarca cerceava qualquer tipo de evolução dos direitos humanos (NISHIYAMA, 2016), o que obviamente acarretava em um descaso arbitrário com as pessoas que tivessem algum tipo de deficiência física ou intelectual.

Ainda nessa fase, registraram-se políticas aterrorizantes de banimento do convívio em sociedade, e com efeito "a prática do infanticídio vigorou por vários séculos" (NISHIYAMA, 2016, p. 28). Na verdade, as chamadas políticas de extermínio das pessoas com deficiência ocorreram em fases e locais diferentes, e se prolongaram por diversos anos. Há relatos históricos da morte logo após o nascimento daqueles que tivessem deficiência na Grécia Antiga ou no Estado Romano (BOLONHINI JUNIOR, 2010).

A brutalidade e total ignorância se repetiu, podendo ser observada em distintos momentos através de diversos tipos de políticas adotadas em relação as pessoas com deficiência. Há na história relatos repletos de crueldade em face a essas pessoas, constando inclusive o registro de políticas de exclusão das mais cruéis possíveis, onde os próprios pais, algumas vezes, eram obrigados a matar o filho logo após o nascimento, simplesmente por questões estéticas ou religiosas.

Os períodos e as formas de tratamento sob as pessoas com deficiência foram compostos por três distintas fases: prescindência, médica e hodiernamente a fase do tratamento social. No modelo de prescindência a deficiência tinha uma base religiosa composta de elementos diabólicos o que justificava o fato de não merecerem viver (MADRUGA, 2016).

Devido a esse entendimento, dotado de crenças e questões religiosas, esse período foi marcado por momentos de violência e crueldade, composto pelo extermínio das pessoas com deficiência sem qualquer tipo de intervenção da sociedade ou do Estado.

Nesse sentido, “é sabido que os povos como os bárbaros nômades, os espartanos, os romanos e outros eliminavam crianças com deficiência em rituais religiosos, ou com apoio legal, conforme previa a própria lei romana das XII Tábuas” (FONSECA, 2012, p. 27), transformando a deficiência em uma pena de morte.

Mais tarde, no século XVIII as crenças da época e o receio da loucura foram elementos importantes para a discriminação de todos aqueles que possuíam deficiências, principalmente àquelas com transtornos intelectuais (NISHIYAMA, 2016, p. 28).

Nessa conjuntura as pessoas com deficiência sofreram incontáveis atos de barbáries, os quais eram realizados com a proteção do Estado, que por crenças, questões religiosas, 
estéticas ou até mesmo preconceituosas, não permitiam a presença de deficientes junto ao convívio das demais pessoas.

Posteriormente a esses períodos, as sociedades foram compelidas a conviver com as diferenças, uma vez que, ao término da Primeira Guerra mundial houve um regresso de inúmeros soldados, os quais trouxeram em seus corpos os resquícios das batalhas enfrentadas. Dessa forma, diante desse novo cenário composto de um vasto contingente de padecentes da guerra, o Estado e a sociedade em geral tiveram que enfrentar a nova realidade que lhes era imposta.

Perante o novo contexto apresentado, repleto de soldados mutilados, com diversos tipos de deficiência e anomalias físicas e psicológicas causadas nas batalhas enfrentadas ao longo do período de guerra, exigiu-se uma nova postura do Estado, o qual precisou criar medidas e mecanismos protetivos das pessoas com deficiência.

Esse período é marcado pela substituição do modelo de prescindência para o modelo médico. Apesar disso, o preconceito e a discriminação ainda mantinham raízes, haja vista que esse modelo compreendia a deficiência como um problema pessoal onde a pessoa com deficiência era nula e improdutiva.

Nesse viés, o modelo médico presumia a necessidade de reabilitação das pessoas com deficiência para que as mesmas tivessem valia perante a sociedade. Ou seja:

O modelo médico/reabilitador, que surge com o fim da Primeira Guerra Mundial, ante os efeitos laborais suportados pelos 'feridos de guerra' considera que as causas que deram origem a deficiência são científicas, e as pessoas com deficiência à medida que sejam reabilitadas não mais são consideradas inúteis ou desnecessárias. Busca-se normalizar as pessoas com deficiência, cujo problema está em suas limitações, daí a necessidade imperiosa de reabilitá-las psíquica, física e sensorialmente. (MADRUGA, 2016, p. 35).

Apesar de manter certo nível de preconceito e discriminação, esse novo modelo trouxe à tona a discussão sobre a deficiência. Foi nesse período em que a temática alcançou visibilidade e necessidade de reflexão mais meticulosa. Há de se destacar esse período, uma vez que diante de todo o quadro apresentado, as pessoas com deficiência obtiveram uma visibilidade mundial, aflorando o debate sobre essa temática nas mais diversas nações.

Pode-se afirmar que as Guerras Mundiais foram divisores fundamentais no tratamento das pessoas com deficiência, pois diante desse novo cenário, houve a necessidade da construção de políticas mais humanitárias e da busca pela concretização dos direitos humanos e do respeito à dignidade das pessoas. 
Inegavelmente, conforme já demonstrado, houve nesse período uma pequena evolução no tratamento do Estado com as pessoas com deficiência, entretanto, o novo modelo adotado após a Primeira Guerra, ainda detinha consigo uma certa discriminação, afinal, perante a ele, as pessoas com deficiência não eram mais expostas as políticas de extermínio, porém, carregavam consigo o estereotipo de serem um fardo para a sociedade necessitando de reabilitação.

Em outras palavras, se extinguiu a política de segregação das pessoas com deficiência, mas, em contrapartida lhes foram imputadas um rótulo de carência de reabilitação para somente assim serem vistas de forma igualitária e possuidoras de direitos.

Nesse viés percebe-se que o preconceito e a discriminação estiveram presentes por longos anos, e somente começaram a ser combatido em decorrência de muitas lutas em busca da igualdade de tratamento e oportunidades.

Após longos períodos de exclusão do meio social, os primeiros a debater e repensar de uma forma mais humana acerca do tratamento das pessoas com mobilidade reduzida foram os americanos, os quais criaram no ano de 1973 a Lei de Reabilitação, devido a uma realidade surgida naquele momento, onde com o retorno de milhares de soldados que regressaram da guerra do Vietnã sobrevieram muitos mutilados (CASTRO, 2013).

Diante desse quadro e da situação que se instaurou, houve a necessidade de refletir a forma como a sociedade convive com as diferenças, e a importância de se pensar sobre as pessoas com deficiência passou a fazer parte da agenda de debate dos governantes e se difundiu pelo resto do mundo na busca por um tratamento mais humano e protetivo.

Nesse contexto pode-se afirmar que "[...] um importante divisor de águas para o estudo da proteção das pessoas portadoras de deficiência foi a ocorrência das duas guerras mundiais, o que fez aumentar, desgraçadamente, o número de pessoas com deficiência de locomoção, audição e visão" (ARAUJO, 1994, p. 15).

Esse aumento de pessoas com deficiência acabou corroborando para que as sociedades de todo o mundo passassem a ter um olhar mais humanizado com essa situação, e se iniciasse um processo de mudanças da forma de como essas limitações são encaradas pelas pessoas e pelos próprios governantes na construção das políticas públicas.

Assim, diante desse quadro foi necessária uma nova postura dos Estados no planejamento de políticas públicas, modificando sua forma de atuação e iniciando uma caminhada de proteção das pessoas como seres humanos, isto é, independentemente de suas características ou peculiaridades.

Perante esse momento crucial que acarretou uma reflexão sobre o novo panorama que passou a se apresentar, muitos países iniciaram um diferente ciclo voltado a trabalhar a questão 
da igualdade e não discriminação. Isso contribuiu para que ocorresse uma transformação comportamental evoluindo de uma visão de que a deficiência era algo a ser tratado, para um novo contexto que a compreende como uma característica pessoal que pode ser minimizada com a igualdade de promoções (BRASIL, 2012).

Por muito tempo a deficiência foi encarada como uma doença, partindo de uma visão totalmente médica, o que resultava no afastamento daqueles que obtinham qualquer limitação. Felizmente com o evoluir dos anos, a ocorrência de conferências e reflexões essa visão foi deixada de lado e diante dos debates internacionais dos direitos humanos, passou a se adotar um modelo social.

Através desse modelo a deficiência passa a ser encarada como uma mera limitação que ocorre diante de obstáculos, mas que pode ser superada através de diversos mecanismos de acessibilidade. Ou seja, a deficiência pode ser minimizada se o meio em que vive ofertar condições de acessibilidade.

Com essa nova acepção,

A deficiência, do ponto de vista social, implica admitir que o problema não está no indivíduo e sim no próprio comportamento estigmatizado em relação àqueles considerados diferentes, e, por esse motivo, inferiorizados e discriminados. Significa que o problema tem raízes sociais, econômicas, culturais e históricas, e sua resolução passa por uma sociedade acessível a todos os seus membros, sem distinção. Significa dizer que a deficiência é uma questão de direitos humanos. (MADRUGA, 2016, p. 17, grifo do autor).

Conforme verificado até o momento, a transformação do tratamento acerca das pessoas com deficiência foi evoluindo gradativamente e consequentemente, mudando a concepção como o Estado e a sociedade encararam e conviveram com as diferenças.

É preciso acima de tudo respeitar as heterogeneidades de cada indivíduo para que os direitos humanos e a dignidade sejam materializados. E o paradigma social vem corroborar com essa visão, onde se parte da premissa que independentemente de quaisquer características do ser humano, a dignidade lhe deve ser assegurada.

Em suma, esses diferentes estágios podem ser sintetizados da seguinte maneira:

A historia da construção dos direitos humanos das pessoas com deficiência compreende quatro fases: a) uma fase de intolerância em relação às pessoas com deficiência, em que esta simbolizava impureza, pecado ou mesmo castigo divino; $b$ ) uma fase marcada pela invisibilidade das pessoas com deficiência; c) uma terceira fase, orientada por uma ótica assistencialista, pautada na perspectiva médica e biológica de que a deficiência era 'uma doença a ser curada', estando o foco no indivíduo 'portador de enfermidade'; e d)finalmente para uma quarta fase, orientada pelo paradigma dos direitos humanos, em que emergem os direitos à inclusão social, 
com ênfase na relação da pessoa com deficiência e o meio em que ela se insere, bem como na necessidade de eliminar obstáculos e barreiras superáveis, sejam elas culturais, físicas ou sociais, que impeçam o pleno exercício de direitos humanos. (PIOVESAN, 2012, p. 46).

Perante a esse novo contexto adotado, cumpre verificar as diferentes formas de proteção dos direitos das pessoas com deficiência, estabelecidas em nível internacional, sempre com o intuito de salvaguardar o ser humano, evitando assim, a reincidência de erros cometidos em épocas anteriores e o impedimento da consumação de direitos.

\title{
3. A proteção internacional dos Direitos das Pessoas com Deficiência
}

Conforme já exposto, após a passagem de momentos bárbaros e impiedosos do Estado em relação às pessoas com deficiência, houve a necessidade de se estabelecer instrumentos protetivos que assegurassem a dignidade e os direitos humanos de cada cidadão.

Assim, "tratar de direitos humanos envolve, antes de mais nada, visualizar a importância atribuída ao homem na história da civilização. É compreender o limite de intervenção do Estado [...]" (GURGEL, 2010, p. 15).

Antes uma figura que impunha medo e terror, foi chegada a hora do Estado agir em prol dos seus cidadãos, e criar mecanismos para sua proteção. Ademais, foi essencial a assimilação de que ao Estado também cabe limitações ao modo de agir.

Isto é,

\begin{abstract}
Além do Estado e dos Poder Públicos, detentores da obrigação de não somente proteger a dignidade do ser humano contra seus próprios atos e de terceiros, mas também de promover uma vida digna para seus jurisdicionados, todas as pessoas físicas e jurídicas estão subordinadas direta e indiretamente ao Princípio da Dignidade da Pessoa Humana, devendo sempre respeitar a dignidade alheia. Isso se justifica, visto que o homem é o ser principal e sobre ele deve gravitar o ordenamento, na tentativa de proporcionar o bem-estar de todo, oferecido, especialmente, por meio dos Direitos Fundamentais. (GURGEL, 2010, p. 32).
\end{abstract}

Dessa forma, coube ao Estado a proteção dos seus cidadãos independentemente de quaisquer características ou particularidades, visando com isso, extinguir os antigos estereótipos aplicado a todos os seres humanos que não fizessem parte daquele rol construído com base na imagem do belo e perfeito.

Trata-se de uma garantia dos direitos humanos, onde a única premissa exigida é a figura do próprio ser humano, ou seja, 
A condição humana é o único requisito para se ter direito à dignidade: não está condicionada à moral, comportamento ou crença religiosa. Mesmo aqueles que cometem as maiores atrocidades possuem dignidade. Todos os seres humanos têm o direito de serem tratados dignamente. Daí porque a comunidade internacional em favor dos Direitos Humanos repudia a tortura, os castigos e o trabalho escravo como instrumentos de sanção, por mais cruel que seja o sujeito. (GURGEL, 2010, p. 30).

Essa visão da necessidade de um tratamento igualitário tornou-se um componente presente em diversos documentos internacionais, demonstrando a preocupação com toda a relevância de se pensar e assegurar os direitos humanos. É uma cautela em nível mundial, que extrapola fronteiras e transcende países na busca da efetividade da dignidade para todas as pessoas.

Nesse contexto, também cabe informar que "o direito à igualdade e a proibição de discriminação são endossados enfaticamente por instrumentos internacionais de proteção dos direitos humanos" (KAMIMURA; PIOVESAN, 2017, p. 534), como o notável documento da Declaração Universal dos Direitos Humanos de 10 de dezembro de 1948, a qual norteia os direitos com fundamento na liberdade e dignidade.

Ademais, recapitulando as fases transcorridas, percebe-se que essa precaução “[...] é fruto do movimento de internacionalização dos direitos humanos, que surge, no pós-guerra, como resposta às atrocidades e aos horrores cometidos durante o nazismo" (PIOVESAN, 2012, p. 37).

A partir desse novo contexto, o Direito Internacional dos Direitos Humanos evoluiu de forma significante, fazendo com que a comunidade internacional voltasse seu olhar para o ser humano de maneira protetiva e assecuratória de direitos. Nessa senda, a união da igualdade e não discriminação "impactará a feição de todo sistema normativo global de proteção dos direitos humanos" (PIOVESAN, 2012, p. 41).

Nas sociedades contemporâneas as políticas públicas e o planejamento do Estado devem se dar em face a garantir a execução dessas políticas e programas, voltados ao bem da coletividade, sempre atuando em prol da concretização dos direitos e da proteção de cada indivíduo, independentemente se suas particularidades.

Por esse ângulo, também é crucial referir que em dezembro de 1975 a Organização das Nações Unidas buscando reafirmar o valor da pessoa promulgou a Declaração dos Direitos das Pessoas Deficientes (1975), invocando a proteção nacional e internacional na promoção da dignidade.

Posteriormente, outro fato marcante nesse contexto ocorreu em 1991, onde a Organização das Nações Unidas (ONU) visando atrair a atenção das comunidades 
internacionais, para a necessidade de articular ações que promovam a igualdade e a dignidade, declarou o ano de 1991 como ano Internacional das Pessoas Deficientes (BRASIL, 1981).

Na sequência, foram publicadas as Normas para Equiparação de Oportunidades para Pessoas com Deficiência da ONU n. ${ }^{\circ}$ 48/96, de 20 de dezembro de 1993, o qual estabeleceu que os Estados devem ofertar um atendimento de saúde adequado as pessoas com deficiência, incluindo todo o apoio necessário para a inclusão.

Já em 28 de maio de 1999 ocorreu a Convenção da Guatemala, também conhecida como Convenção Interamericana para Eliminação de todas as formas de discriminação contra as pessoas portadoras de deficiência, a qual foi adotada por diversos países, incluindo o Brasil na busca pela prevenção e a extinção da discriminação.

Também, é fundamental destacar que no ano de 2006 a Organização das Nações Unidas instaurou a Convenção sobre os Direitos das Pessoas com Deficiência, colaborando assim, de forma direta para a reflexão do papel do Estado frente aos direitos de todos aqueles que possuem qualquer tipo de limitação ou deficiência, seja ela intelectual ou física.

Pode-se afirmar que "a Convenção sobre os Direitos das Pessoas com Deficiência constitui-se no mais abrangente e significativo documento internacional dedicado exclusivamente às pessoas com deficiência [...]" (MADRUGA, 2016, p. 193), representando dessa forma um grande marco no combate à discriminação.

Importante apontar que o Brasil realizou uma atitude inédita pós convenção, assumindo uma postura de responsabilidade quanto a proteção da dignidade,

[...] a Convenção sobre os Direitos das Pessoas com Deficiência e seu Protocolo Facultativo passam a ser o primeiro Tratado Internacional a ingressar na nossa ordem jurídica interna com status de equivalência constitucional, por ter sido aprovado nos exatos termos da regra imposta pelo $\S 3^{\circ}$ do artigo $5^{\circ}$ da Constituição Federal. (FORNASIER; LEITE, 2016, p. 923).

Isso representou um marco de extrema relevância na luta pela concretização dos direitos de todos aqueles que por longos períodos necessitaram lutar para poder fazer parte do meio em que vivem. Com essa atitude, pela primeira vez, um tratado internacional passa a ter notoriedade e equivalência constitucional no ordenamento brasileiro.

Nesse sentido,

Ao ratificar o Protocolo Facultativo da Convenção sobre os Direitos das Pessoas com Deficiência, o Estado brasileiro comprova o respeito pelos direitos humanos, pois reconhece a competência do Comitê, formado em 3 de novembro de 2008, para receber e considerar comunicações formais de pessoas com deficiência ou de grupos de pessoas que aleguem violação dos direitos contidos na convenção. Desse modo, a 
rigorosa observância dos direitos das pessoas com deficiência no Brasil passa a estar garantida tanto no âmbito interno como na esfera do sistema do direito internacional. (RESENDE; VITAL, 2008, p. 16).

Dessa forma, inicia-se uma nova caminhada que agora conta com participação dos mais diferentes atores em nível internacional na união de esforços com escopo de impedir qualquer tipo de violação dos direitos fixados na Convenção.

Fica demonstrado a todos que a deficiência não é impedimento para a realização de tarefas e garantias de direitos, mas sim, que cabe a sociedade de modo geral, principalmente ao Estado, proteger e promover a inclusão através das políticas públicas. Afinal,

A deficiência está, doravante, nas barreiras sociais que excluem essas pessoas do acesso aos direitos humanos básicos. Trocando em miúdos, quero dizer que a deficiência não está na pessoa e sim na sociedade, que deve, como determinam todos os demais dispositivos da Convenção da ONU, buscar políticas públicas para que os detentores daqueles atributos outrora impeditivos emancipem-se. (FONSECA, 2012, p. 27).

Essa busca por uma qualidade de vida de todos aqueles que possuem qualquer tipo de deficiência deve ser um elemento importante no desenvolvimento das políticas públicas, uma vez que todas as fases de banimento e ignorância acerca dessa característica foram superadas com o passar dos anos, através de estudos, debates e reflexões.

Aquele antigo paradigma de pessoa com deficiência remeter a uma condenação de morte ou segregação, já se demonstrou totalmente inadequado e justamente por isso os documentos internacionais se agregam e intercomunicam na busca pela premissa da dignidade.

Ao se atingir esse patamar que promove o debate, e persegue a dignidade acima de todas as normas procurando garantir a concretização dos direitos das pessoas com deficiência, é fundamental verificar a postura exercida pelo Brasil após a ratificação do protocolo, buscando averiguar a continuidade dessa nova óptica quanto a dignidade de todos.

\section{O ordenamento jurídico brasileiro e o tratamento conferido às pessoas com deficiência}

No Brasil o número de pessoas com algum tipo de deficiência é significativo, e conforme o Instituto Brasileiro de Geografia e Estatística (IBGE) apontou no último censo, cerca de um quarto da população declara ter algum tipo de deficiência (ARAUJO; MAIA, 2015). Isso exige uma atenção do Estado para com essas pessoas, sendo necessário o reforço e 
a construção diária de um novo olhar não discriminatório acrescido pela promoção de ambientes adequados para a inclusão de todos.

Hodiernamente é algo totalmente inconcebível de se imaginar no Estado brasileiro, as já referidas políticas de extermínio das pessoas com deficiência, porém, há de se atentar ao fato de que mesmo que o Estado não adote essas lamentáveis medidas de exclusão pelo óbito precoce, ou outras formas de segregação, as pessoas com deficiência ainda padecem longamente à espera da concretização de infinitos direitos fundamentais.

Devido suas limitações ou deficiências, travam constantes batalhas perante a sociedade, que muitas vezes não está apta para conviver com as diferenças, ocupando muitas vezes um lugar de vulnerabilidade (NISHIYAMA, 2016) diante do preconceito e consequentemente do sentimento de não pertencimento do espaço onde vivem.

Isso ocorre pois "o que se nota culturalmente é a prevalência da ideia de que toda pessoa surda, cega, paraplégica, amputada ou com qualquer desses impedimentos foge dos padrões universais e tem por isso um 'problema' que não diz respeito à coletividade" (FONSECA, 2012, p. 24). Esse pensamento necessita ser urgentemente repelido da sociedade, para que as pessoas com deficiência possam usufruir dos seus direitos e ter preservada sua dignidade como qualquer outro cidadão.

Não raras as vezes, muitas pessoas com deficiência acabam se afastando dos espaços de convívio social pela falta de adequações e acessibilidade que permitam sua locomoção e participação nas mais diversas maneiras em atividades corriqueiras. Apesar da evolução do entendimento acerca da deficiência, as cidades muitas vezes não propiciam o espaço adequado para o lazer, educação, saúde e a livre locomoção daqueles que possuem deficiências.

Infelizmente, essa realidade apresenta um viés discriminatório que acarreta diretamente em é "uma inversão no processo de inclusão social: não é a sociedade que se adapta para recepcionar o deficiente, mas sim, o portador de necessidade especial que se adapta para integrar à sociedade" (BOLONHINI JUNIOR, 2010, p. 30).

$\mathrm{Na}$ mesma concepção, fica claro que o país ainda não está adequado para uma convivência compatível com os preceitos constitucionais, haja vista que:

Embora no Brasil 14,5\% da população seja portadora de necessidade especial, estando, portanto, acima da média da Organização Mundial de Saúde (OMS), o fato é que a comunidade pátria não se encontra preparada para conviver em harmonia com essas pessoas. Prova disso é o processo de exclusão social que muitos deficientes sofrem, sendo desrespeitados em situações elementares do seu dia a dia, como, por exemplo, pela inexistência de rampas em prédios públicos e privados, falta de transporte público adaptado [...]. (BOLONHINI JUNIOR, 2010, p. 21). 
Vale recordar que a Constituição Federal vigente, incumbiu-se de arrolar os direitos fundamentais, e principalmente, de prever que o Estado deve assegurar a concretização da igualdade de todos, perseguindo assim a inclusão dos cidadãos. Nesse contexto, pode-se sintetizar que a Constituição de 1988 trouxe a igualdade como basilar, e concomitante a isso, também estipulou a proibição da discriminação (ALMEIDA, 2011).

Portanto, a premissa da igualdade deve prevalecer na construção e execução das políticas públicas, bem como nos serviços ofertados pelos municípios a todos os seus munícipes.

Ademais a dignidade humana é um princípio constitucional elencado na Constituição Federal de 1988 logo em seu art. $1^{\circ}$, III $^{1}$ como um dos fundamentos sob os quais a República Federativa do Brasil deve agir, sempre pensando na proteção dos indivíduos.

Deste modo, “como um valor fundamental que é também um princípio constitucional, a dignidade humana funciona tanto como uma justificação moral quanto como fundamento jurídico - normativo dos direitos fundamentais" (BARROSO, 2016, p. 65).

Assim sendo, cabe ao Estado atuar em prol da igualdade e da garantia da dignidade humana, deixando no passado os atos de barbáries e crueldade, e por consequência protegendo os seus cidadãos de acordo com os dispositivos elencados na Constituição vigente. Entretanto, é necessário a compreensão de que

\footnotetext{
A positivação constitucional de direitos relativos às pessoas portadoras de deficiência é uma grande conquista, e, por isso, não pode ser esquecida ou subestimada, sendo fruto de uma evolução histórica importante, uma vez que interage com os Direitos Humanos e com a cidadania. Contudo, só a positivação desses direitos não basta, é preciso a garantia de seu efetivo exercício. (ATIQUE; VELTRONI, 2007, p. 15).
}

Porém, cabe salientar que essa proteção se estende muito além de não executar atos sacrifício ou penas de morte devido as características físicas dos cidadãos, é uma proteção de toda a dignidade humana, que se frustra cada vez que os seus direitos fundamentais não podem ser executados pois a sociedade não prevê oportunidades de acesso ou espaços aptos a recepcionar as pessoas com deficiência.

Por essa óptica, "garantir os direitos das pessoas com deficiência não é, pois, ato de caridade, mas decorrência da Lei que exige respeito à dignidade da pessoa e observância ao direito à igualdade" (NISHIYAMA, 2017, p. 168). Quando se fala em igualdade, deve-se ter

\footnotetext{
${ }^{1}$ Art. $1^{\circ}$ A República Federativa do Brasil, formada pela união indissolúvel dos Estados e Municípios e do Distrito Federal, constitui-se em Estado Democrático de Direito e tem como fundamentos: I - a soberania; II - a cidadania; III - a dignidade da pessoa humana; IV - os valores sociais do trabalho e da livre iniciativa; V - o pluralismo político (BRASIL, 1988, online).
} 
claro que perante a lei todas as pessoas são iguais, e cabe ao estado propiciar mecanismos de promoção dessa igualdade.

Portanto, independente das limitações que as pessoas com deficiência possuam, cabe ao Estado o tratamento isonômico perante a todos os cidadãos, devendo além disso, realizar medidas que possam contribuir para a inexistência da discriminação das pessoas com deficiência, e o ofertamento de espaços e políticas que busquem a inclusão social.

Nessa lógica, há de se destacar que no ano 2000 essas preocupações foram vastamente refletidas e estudadas, gerando a publicação de duas leis de grande significância para todos aqueles que possuem qualquer tipo de deficiência. Trata-se das Leis 10.048 e 10.098 de 2000, as quais englobam elementos importantes, como a prioridade de atendimento, e estipulam diretrizes quanto a promoção da acessibilidade.

Ou seja,

A Lei 10.098/00 estabelece normas gerais e os critérios básicos para a promoção da acessibilidade mediante a supressão de barreiras e obstáculos nas vias e espaços públicos, no mobiliário urbano na construção e reforma de edifícios e nos meios de transporte e de comunicação. (SÃO PAULO, 2016, p. 16).

Diante dessas premissas, percebe-se que o Estado assumiu sua responsabilidade no zelo e cuidado com as pessoas, diferentemente de épocas antepassadas quando ele próprio combatia a presença e participação das pessoas com deficiência na sociedade.

O que se nota com esse avanço legislativo é uma preocupação em relação a oportunidade igualitária do convívio entre todos nos espaços públicos, através de um planejamento que extermine com as barreiras arquitetônicas ou urbanísticas e diante disso, contemplem a harmonia nos espaços e serviços públicos que possam recepcionar qualquer cidadão independentemente de suas características.

Ambas as leis foram regulamentadas em 02 de dezembro de 2004 com a publicação do Decreto 5.296 que representou mais um avanço no trato dessa temática tão relevante. A posteriori, pode-se afirmar que o grande ápice a ser destacado ocorreu com a publicação da Lei 13.146 em 06 de julho de 2015. A referida lei também é denominada Estatuto da Pessoa com Deficiência, e apresenta como alguns de seus objetivos a promoção de igualdade, o exercício dos direitos fundamentais e a inclusão social.

Ressalta-se que todo esse aparato legal tem como premissa basilar a dignidade humana, princípio constitucional que deve nortear a atuação do Estado e considerar a importância de cada pessoa como única. 
O portador de necessidade especial requer do Estado e da sociedade somente aquilo que lhe é legítimo: o fim do preconceito, as mesmas oportunidades de emprego, na escola, no lazer, no transporte, na saúde, etc. Deseja o deficiente, apenas, ser respeitado na sua dignidade humana, na sua cidadania, mesmo tendo consciência de que, para tanto, algumas adaptações sociais devam ser feitas. O portador de necessidade especial não nega sua condição de deficiente; exige apenas o respeito à condição de ser humano. (BOLONHINI JUNIOR, 2010, p. 26).

Sob esse ângulo o Estatuto estipula que "não serão tolerados qualquer entrave, obstáculo, atitude ou comportamento que limite ou impeça a participação social da pessoa, bem como o gozo, a fruição e o exercício de seus direitos [...]” (PASSARELLI, 2016, p. 348), reforçando a importância do respeito à dignidade humana.

Justamente por essa condição de ser humano, todas as pessoas deveriam poder usufruir dos direitos fundamentais previstos na norma constitucional vigente, porém, a própria liberdade de ir e vir é muitas vezes tolhida diante das dificuldades urbanísticas e arquitetônicas presentes nas cidades.

Esses óbices contribuem diretamente para a exclusão das pessoas com deficiência da participação nos espaços de uso coletivo, seja por temor de situações vexatórias, ou mesmo por uma forma de autopreservação. Há de se refletir sob muitas circunstâncias as quais essas pessoas têm sua dignidade completamente abalada e por consequência o impedimento da concretização de diversos direitos.

De que adianta um transporte coletivo adaptado se as ruas e o acesso ao ponto de ônibus não se encontram aptas para receber as pessoas com deficiência? Da mesma forma, o direito à saúde é cerceado quando não há acesso adequado nas unidades de saúde que atendem a população, bem como não há direito ao lazer quando se depara com “[...] museus e outros espaços públicos não acessíveis a pessoa com deficiência, ausência de exemplares em braile de livros didáticos [...]" (GONZAGA, 2012, p. 23), entre outros. São fatos como esses que além de frustrarem a dignidade, também contribuem diretamente para a exclusão do convívio social.

Nesse contexto,

O reconhecimento da dignidade das pessoas com deficiência defronta-se com a inexorável realidade de exclusão social, política, econômica e cultural. A exclusão dessas pessoas significa verdadeira violação da sua dignidade humana, na medida que só faz crescer sua invisibilidade ante o meio social, apartando-as cada vez mais desse último. (MADRUGA, 2016, p. 36).

De modo igual, é necessário ter claramente a concepção de que: 
Pessoas com deficiência são, antes de tudo, pessoas como quaisquer outros, com protagonismos, peculiaridades, contradições e singularidades. Pessoas que lutam por seus direitos, que valorizam o respeito pela dignidade, pela autonomia individual, pela plena e efetiva participação e inclusão na sociedade e pela igualdade de oportunidades. E, para que isso aconteça, a acessibilidade - em todos os sentidos - é primordial. (CASTRO, 2013, p. 69).

Sendo assim, os olhos do Estado e consequentemente a preocupação por parte dos gestores públicos deve estar focada na promoção de políticas e programas de inclusão, que garantam os mesmos direitos a todos, tendo como premissa basilar a dignidade de cada cidadão e o respeito aos direitos humanos.

\section{Conclusão}

Diante do exposto ao longo do presente artigo percebe-se o quanto a visão sob as pessoas com deficiência evoluiu ao longo das décadas, perpassando momentos em que o Estado era detentor do direcionamento da vida dessas pessoas, da forma que melhor lhe coubesse até o período em que o cenário do pós-guerra trouxe uma nova realidade a qual obrigou a adoção de novas formas de agir e pensar sobre o tema.

Na presente pesquisa verificou-se as distintas formas de tratamento e receptividade nas sociedades mundiais em face as pessoas com deficiência e seus direitos, em uma linha evolutiva da (in)diferença até a conquista da atenção internacional na defesa de direitos e garantias humanas.

Como consequência, ocorreram nas últimas décadas diversos seminários, convenções e tratados que demonstraram a necessidade de se estabelecer um tratamento mais igualitário e garantista dos direitos humanos, onde coube ao próprio Estado limitações em suas atuações e a busca pela proteção da dignidade e promoção da inclusão. passou a ser o protetor dessas pessoas.

Dessa forma, a dignidade da pessoa humana e o princípio da igualdade atuam na atualidade como balizadores de toda ação do Estado, que deve proteger seus cidadãos e respeitálos independentemente de suas características ou particularidades.

Nessa senda, ao analisar a problemática, verificou-se grandes conquistas como a Convenção Internacional sobre os Direitos das Pessoas com Deficiência, previsão constitucional da igualdade e dignidade, além da publicação do Estatuto das Pessoas com Deficiência como grande norteador das políticas do Estado em face a promoção de igualdade, acessibilidade e dignidade. 
Portanto, a evolução da forma como o Estado trata seus cidadãos deficientes, prosperou de maneira muito significativa, deixando de lado as políticas de segregação e adotando um novo parâmetro mundial em busca do respeito aos direitos humanos e da dignidade de cada um, independentemente de suas peculiaridades.

\section{Referências bibliográficas}

ALMEIDA, Luciana Dayoub Raniere de. Ações afirmativas e a concretização do princípio da igualdade no direito brasileiro. Belo Horizonte: Fórum, 2011.

ARAUJO, Luiz Alberto David. A proteção constitucional das pessoas com deficiência. Brasília: CORDE, 1994.

ARAUJO, Luiz Alberto David; MAIA, Maurício. Meio ambiente urbano constitucional e o cumprimento das regras de acessibilidade. Revista de Direito Ambiental, São Paulo, v. 79, p. $341-448$, jul./set. 2015 .

ATIQUE, Andraci Lucas Veltroni; VELTRONI, Alexandre Lucas. A pessoa portadora de deficiência e a educação no Brasil. Revista de Direito Constitucional e Internacional, São Paulo, v. 60, p. 7-34, 2007.

\section{BARROSO, Luís Roberto. A dignidade da pessoa humana no direito constitucional} contemporâneo: a construção de um conceito jurídico à luz da jurisprudência mundial. Belo Horizonte: Fórum, 2016.

BOLONHINI JUNIOR, Roberto. Portadores de necessidades especiais: as principais prerrogativas dos portadores de necessidades especiais e a legislação brasileira. 2. ed. São Paulo: Atlas, 2010.

BRASIL. Comissão Nacional. Relatório de atividades. Ano internacional das pessoas deficientes. Brasília, DF: Ministério da Cultura, 1981. Disponível em: $<$ http://www.dominiopublico.gov.br/download/texto/me002911.pdf $>$. Acesso em: 05 maio 2018. 
Constituição da República Federativa do Brasil de 1988. Brasília, DF, 1988.

Disponível em: < http://www.planalto.gov.br/ccivil_03/constituicao/constituicao.htm>. Acesso em: 3 fev. 2018.

. Secretaria Nacional de Promoção dos Direitos da Pessoa com Deficiência. Secretaria de Direitos Humanos da Presidência da República. Avanço das políticas públicas para as pessoas com deficiência: uma análise a partir das Conferências Nacionais. Brasília, DF: Secretaria Especial dos Direitos Humanos, 2012.

CASTRO, Jary de Carvalho. Ir e vir: acessibilidade compromisso de cada um. Campo Grande: Gibim, 2013.

DECLARAÇÃO dos direitos das pessoas deficientes. Resolução aprovada pela Assembleia Geral da Organização das Nações Unidas em 09/12/75. Genebra, 1975. Disponível em: $<$ http://portal.mec.gov.br/seesp/arquivos/pdf/dec_def.pdf>. Acesso em: 29 abr. 2018.

FONSECA, Ricardo Tadeu Marques. Novo conceito constitucional de pessoa com deficiência: um ato de coragem. In: FERRAZ, Valença Carolina et al. Manual dos direitos da pessoa com deficiência. São Paulo: Saraiva, 2012.

FORNASIER, Mateus de Oliveira; LEITE, Flavia Piva de Almeida. Direitos fundamentais à acessibilidade e à mobilidade urbana da pessoa com deficiência: uma abordagem sistêmica autopoiética. Revista Direito da Cidade, Rio de Janeiro, v. 8, n. 3. p. 908-933, 2016.

GONZAGA, Eugenia Augusta. Direito das pessoas com deficiência: garantia de igualdade na diversidade. Rio de Janeiro: WVA, 2012.

GURGEL, Yara Maria Pereira. Direitos humanos, princípio da igualdade e não discriminação: sua aplicação às relações de trabalho. São Paulo: LTr, 2010.

KAMIMURA, Akemi; PIOVESAN, Flávia. Proteção internacional dos direitos humanos das pessoas idosas. In: PIOVESAN, Flávia. Temas de direitos humanos. São Paulo: Saraiva, 2017. 
MADRUGA, Sidney. Pessoas com deficiência e direitos humanos: ótica da diferença e ações afirmativas. São Paulo: Saraiva, 2016.

NISHIYAMA, Adolfo Mamoru. Os direitos das pessoas com deficiência e sua transformação histórica. Revista dos Tribunais, São Paulo, v. 986, p. 167-188, 2017.

Proteção jurídica das pessoas com deficiência nas relações de consumo. Curitiba: Juruá, 2016.

PASSARELLI, Luciano Lopes. Estatuto da Pessoa com Deficiência: reflexões aplicadas ao direito notarial e registral. Revista de Direito Imobiliário, São Paulo, v. 39, n. 80, p. 348, 2016.

PIOVESAN, Flávia. Convenção da ONU sobre os direitos da pessoa com deficiência: inovações, alcance e impacto. In: FERRAZ, Valença Carolina et al. Manual dos direitos da pessoa com deficiência. São Paulo: Saraiva, 2012.

RESENDE, Ana Paula Crosara; VITAL, Flávia Maria de Paiva (Coord.). A convenção sobre os direitos das pessoas com deficiência: versão comentada. Avanço das políticas públicas para as pessoas com deficiência: uma análise a partir das Conferências Nacionais. Brasília, DF: Secretaria Especial dos Direitos Humanos, 2008.

SÃO PAULO (Estado). Acessibilidade nos municípios: como aplicar o Decreto 5.296/04. 2. ed. São Paulo: Fundação Prefeito Faria Lima, 2009. 


\title{
TRIBUNAL HÍBRIDO DO CAMBOJA: INSTRUMENTO JUDICIAL PARA A PROTEÇÃO DOS DIREITOS HUMANOS
}

\author{
Renata Mantovani de Lima \\ Universidade de Itaúna/MG
}

\section{Resumo}

A justiça e a responsabilidade em situações de violação de direitos humanos proporciona importantes reflexões. A preocupação é sobre a maneira não só de punir os responsáveis, mas de estabelecer mecanismos que garantam a jurisdicionalização internacional. Por meio de levantamento bibliográfico e jurisprudencial, propõe-se estudar o processo de construção de uma jurisdicionalização tida como híbrida no Camboja, com fulcro a restaurar e a garantir a paz nesse Estado. Partindo de apontamentos históricos do conflito, as características e a composição do Tribunal permitem demonstrar que os direitos humanos são fundamentais para a consolidação de um sistema de Direito Internacional Penal.

Palavras-chaves: Responsabilidade Internacional, Conflito Armado, Direitos Humanos, Direito Humanitário, Jurisdicionalização Internacional

\begin{abstract}
Resumen/Résumé
Justice and responsibility in situations of human rights violations provides important insights. The concern is not only about punishing those responsible, but about establishing mechanisms that guarantee international jurisdictionalisation. Through a bibliographical and jurisprudential survey, it is proposed to study the process of building a jurisdictionalisation considered as a hybrid in Cambodia, with a focus to be restored and to guarantee peace in that State. Based on historical notes on the conflict, the characteristics and composition of the Court allow us to demonstrate that human rights are fundamental to the consolidation of a system of international criminal law.
\end{abstract}

Keywords/Palabras-claves/Mots-clés: International Responsibility, Armed Conflict, Human Rights, Humanitarian Law, International jurisdictionalization. 


\section{Introdução}

A construção de uma jurisdicionalização internacional penal pode ser verificada ao longo de diversos pontos da história mundial. Isso porque, intrinsecamente ligado aos fatos sociais, o Direito acaba sendo condicionado pelos comportamentos da sociedade, que, por sua vez, é igualmente condicionada pelas normas jurídicas. Nesse particular é necessário esclarecer que condicionar implica em influir, interferir, fazendo gerar a expectativa de que Direito e sociedade hajam de acordo com determinada forma ${ }^{1}$. E é evidente que para regular tanto as relações internas quanto as relações internacionais, impõe-se a necessidade de normativas jurídicas específicas.

Concernente à esfera internacional é de se dizer que, com o crescente aumento e intensidade das relações entre os atores estatais, aliado à delicada complexidade dessas mesmas relações, os conflitos entre as nações de todo o orbe tornam-se algo potencial. Emerge, então, a necessidade de institucionalização e imposição de regras que, alicerçadas no direito das gentes ${ }^{2}$, suplantem a limitação dos ordenamentos jurídicos internos em equacionar condutas que extrapolem fronteiras nacionais, além de nortear a punição de transgressões cujos efeitos se projetam para toda a sociedade internacional.

O envolvimento dos Estados nacionais em disputa de poder, a diversidade étnica, cultural e religiosa do elemento humano que compõe esses Estados, a ameaça terrorista, bem como o desenvolvimento econômico e tecnológico, fundamentam e implicam o aumento do poder destrutivo dos conflitos armados. Aliado a tal fato, a proporção de vítimas envolvidas em

\footnotetext{
${ }^{1}$ As normas sociais quando institucionalizadas impõem certos padrões de comportamento que objetivam reger e regular a vida social. Por isso mesmo é que acaba por interferir nas condutas das pessoas no meio social. Desse modo é certo que a sociedade interage com o direito e é por ele influenciada. Assim, ao instituir normas jurídicas, moldam a sociedade; contudo esta também dita padrões que sai da informalidade, adotando a roupagem da positivação.

${ }^{2} \mathrm{O}$ direito das gentes posiciona o indivíduo no centro do sistema das relações internacionais. Antônio Augusto Cançado Trindade discorre acerca do assunto: "Em última análise, todo o Direito existe para o ser humano, e o direito das gentes não faz exceção a isto, garantindo ao indivíduo seus direitos e o respeito de sua personalidade". Esse mesmo autor fornece ainda reflexões de importantes teólogos acerca do direito das gentes. Para de Francisco Suárez, "o direito das gentes revela a unidade e universalidade do gênero humano; os Estados têm necessidade de um sistema jurídico que regule suas relações, como membros da sociedade universal". Na apreciação de Francisco de Vitória, "o direito das gentes regula uma comunidade internacional constituída de seres humanos organizados socialmente em Estados e coextensiva com a própria humanidade; a reparação das violações de direitos (humanos) reflete uma necessidade internacional atendida pelo direito das gentes, com os mesmos princípios de justiça aplicando-se tanto aos Estados como aos indivíduos ou povos que o formam". Já na concepção do jus gentium de Hugo Grotius "o Estado não é um fim em si mesmo, mas um meio para assegurar o ordenamento social consoante a inteligência humana". TRINDADE, Antônio Augusto Cançado. Direitos Humanos: Personalidade $e$ Capacidade Jurídica Internacional do Indivíduo, p 202 e 239.
} 
conflitos, quer combatentes, ex-combatentes, e população civil, atingiu níveis alarmantes no final de século $\mathrm{XX}^{3}$.

É certo, contudo, que a natureza dos conflitos vem se modificando desde o fim da Guerra Fria, repercutindo em uma progressiva diminuição de vítimas fatais. Se as duas Grandes Guerras vitimaram cerca de 70 milhões de pessoas, os conflitos atuais, embora crescentes e numerosos, somam algo em torno dos 3 milhões.

Atualmente, os conflitos interestatais cederam lugar para os conflitos intraestatais ${ }^{4}$. Nesse sentido, é possível depreender que, se aparentemente, ou ainda teoricamente, a cooperação entre os Estados, o respeito às normas de direitos humanos e os mecanismos de negociação vêm se mostrando eficientes, e consequentemente evitando ou minorando a eclosão de guerras, no plano interno de muitos Estados o mesmo não ocorre. Aliás, é aí que as maiores violações aos direitos humanos tomaram lugar nos últimos tempos. Os conflitos que anteriormente tinham progressão mundial e fundamento em uma disputa ideológica passam a se destacar por sua natureza cultural e política que, por sua vez, provoca a desintegração de um conjunto de valores capazes de fundamentar a legitimidade do Estado, ou do Poder vigente 5 .

Neste contexto, podem-se incluir diversos conflitos deflagrados no continente africano e asiático em que etnias e grupos religiosos são perseguidos, demonstrando uma clara preferência à ideia de grupo em detrimento da noção de identidade nacional ou de convivência divergente. Essa última entendida como a coabitação de pessoas com tradições, culturas e características distintas, embora juridicamente e politicamente submetidas a um mesmo Estado $^{6}$.

\footnotetext{
${ }^{3}$ No total os conflitos armados do século XX provocaram cerca de 90 milhões de vítimas fatais. Informações disponíveis nos documentos - barômetros elaborados pelo Heidelberg Institute on International Conflict Research. Disponível em: <http:// www.hiik.de/en/index.html $>$.

4 "In 2010, a total of 363 conflicts were observed. Among these were six wars and 22 severe crises, amounting to 28 highly-violent conflicts, i.e. conflicts fought out with the use of massive violence". $19^{\text {th }}$ Annual Conflict Analysis. Disponível em: <http:// www.hiik.de/en/index.html $>$.

${ }^{5}$ CICR. Los conflictos armados relacionados com la desintegración de las estructuras del Estado. Documento preparatorio del Comité Internacional de la Cruz Roja para la primera reunión periódica sobre el derecho internacional humanitário. Ginebra, 19-23 de enero de 1998. Disponível em: < http://www.icrc.org/spa/resources/documents/misc/5tdlnd.htm>.

${ }^{6}$ Nesse sentido dispõe o Pacto dos Direitos Civis e Políticos de 1966: “Artigo 25: Todo cidadão terá o direito e a possibilidade, sem qualquer das formas de discriminação mencionadas no artigo $2^{\circ}$ e sem restrições infundadas: de participar da condução dos assuntos públicos, diretamente ou por meio de representantes livremente escolhidos; de votar e ser eleito em eleições periódicas, autênticas, realizadas por sufrágio universal e igualitário e por voto secreto, que garantam a manifestação da vontade dos eleitores; de Ter acesso, em condições gerais de igualdade, às funções públicas de seu país. Artigo 26: Todas as pessoas são iguais perante a lei e têm direito, sem discriminação alguma, a igual proteção da lei. A este respeito, a lei deverá proibir qualquer forma de discriminação e garantir a todas as pessoas proteção igual e eficaz contra qualquer discriminação por motivo de raça, cor, sexo, língua, religião, opinião política ou de outra natureza, origem nacional ou social, situação econômica, nascimento ou qualquer outra situação. Artigo 27: Nos Estados em que haja minorias étnicas, religiosas ou linguísticas, as pessoas pertencentes a essas minorias não poderão ser privadas do direito de ter, conjuntamente com outros
} 
Em conflitos desse tipo, a transgressão e o desrespeito aos direitos das minorias mostram-se evidentes, os prejuízos e perdas econômicas incomensuráveis, e a paz e segurança internacionais ameaçadas. Assim, para fazer frente a essas questões e com o intuito de compor essas relações, medidas de diferentes espécies são adotadas pela sociedade internacional e por organismos internacionais. Apenas a título de exemplo citam-se as declarações de repúdio por parte dos Estados, as intervenções humanitárias e a instauração de Tribunais pela Organização das Nações Unidas.

Ressalta-se que, embora consideráveis, o presente artigo não tem por objetivo analisar as razões dos múltiplos conflitos deflagrados recentemente, a tendência internacional das manifestações beligerantes, ou mesmo as medidas empregadas para a contenção desses conflitos, mas, apenas e tão somente, examinar as questões relativas ao conflito do Camboja e a consequente instauração das Câmaras Extraordinárias do Camboja, meio jurídico utilizado para garantir a efetividade da proteção dos direitos humanos.

Desse modo, em um primeiro momento, serão apresentadas as bases históricas que determinaram o conflito. Posteriormente serão tecidas considerações sobre a formação do Tribunal, sua base jurídica, competências diversas, relação com o ordenamento jurídico do Camboja, composição, financiamento, para assim demonstrar que se trata de um mecanismo de composição. Isto é, ao perseguir crimes, identificando responsáveis, garantindo as premissas básicas e essenciais a um julgamento justo e imparcial, ainda que repressivamente, ou a posteriori, os direitos fundamentais de uma parcela social, violados em função do desrespeito à composição multiétnica, da diversidade religiosa e política encontram respaldo por uma tutela jurisdicional internacional.

\section{Apontamentos históricos do conflito e a formação das Câmaras Extraordinárias do Camboja}

Situado no sudeste asiático, o Camboja possui uma população de quase quatorze milhões de pessoas, em sua maioria de descendência Khmer, seguidores do budismo. Faz fronteira com a Tailândia, Laos e Vietnã, de onde deriva outra parte da população. A capital e a maior cidade é Phnon Penh. País essencialmente agrícola, é geograficamente formado por planícies férteis onde vive grande parte dos cambojanos.

membros de seu grupo, sua própria vida cultural, de professar e praticar sua própria religião e usar sua própria língua". 
Seu período de ouro foi, sem dúvida nenhuma, o imperial, datado de 800 a 1450. Essa época é destacada como o apogeu do poder político, da expansão territorial e do urbanismo, da produção cultural, arquitetônica e de engenharia. A partir daí o país experimentou um declínio gradual, com guerras civis, rebeliões, invasões, somado à perda de territórios. Conflitos constantes com os vizinhos, cada vez mais poderosos, especialmente a Tailândia e o Vietnã, acabaram por dizimar a população, enfraquecer e empobrecer, consideravelmente, o Império. As invasões estrangeiras e a disputa pelo poder e por seus territórios perpetraram até a metade do século XIX.

Por volta de 1860, quando os exploradores franceses ocupam o sul do Vietnã com o intuito de expandir seus interesses comerciais no sudeste da Ásia, o então Rei do Camboja, Norodom, que assumira o poder com o auxílio Tailandês, solicita proteção à França contra os vizinhos Tailândia e Vietnã. Os franceses, que estavam ansiosos para aumentar o controle sobre a região, além de acreditar que o Camboja seria uma passagem para a China, assinam um acordo (1863) com o Rei para estabelecer um protetorado sobre o seu reino. Para a surpresa e desprazer de Norodom, marginalizado pela administração francesa, a proteção ao longo dos anos vindouros, transformou-se em controle político e econômico. Embora tivessem mantido o Rei, e oficialmente declarado como um protetorado, o Camboja, no final do século 19, era, na realidade, parte da colônia da Indochina Francesa ${ }^{7}$. Os cambojanos eram impedidos de realizar quaisquer atividades políticas significativas, sem dizer que os três sucessores de Norodom foram indicados pela França ${ }^{8}$. O último, no entanto, contrariando as expectativas francesas, possuía ideais de liberdade. Muito em função do sentimento nacionalista pós Segunda Guerra Mundial proporcionado pela doutrina Comunista e liderado pelo recém surgido Partido Popular Revolucionário do Kampuchea (PPRK), posteriormente denominado Partido Comunista do Kampuchea (PCK). Assim, aos 09 de novembro de 1953, sob o reinado de Norodom Sihanouk, o Camboja tornou-se independente, declarando-se uma monarquia constitucional.

De 1955 a 1966, Sihanouk governou amplamente, tendo vencido todas as eleições para a Assembleia Nacional. Contudo, sofreu uma forte oposição da esquerda que, com violentas rebeliões, insurgia-se contra o governo. O movimento comunista do Camboja era liderado por Pol Pot que, em 1962, assumiu secretamente o controle do PCK, denominado "Khmers Vermelhos" pelo então governante.

\footnotetext{
${ }^{7}$ Exceção feita durante a Segunda Guerra Mundial (1941 a 1945), quando o Império Japonês dominou a região. 8 As informações estão disponíveis no site oficial do tribunal Cambojano. $<$ http://www.cambodiatribunal.org/history/cambodian-history.htmll . Acesso em 06 out. 2010. Para um breve e interessante relato sobre a Biografia Oficial de Pol Pot: KIERNAM, Ben. Justiça para o Camboja. Leituras da História Especial, São Paulo, ano I, n. 2, p. 60-67, 2008.
} 
Em 1970, os EUA, receosos de um possível governo comunista no Camboja, aproveitam a viagem de Sihanouk a Moscou e Pequim, e auxiliaram o então Primeiro-Ministro, Marechal Lon Nol, a assumir o poder por meio de um golpe de Estado. O governo, entretanto, possuía autoridade limitada aos centros urbanos, o que possibilitou a expansão e fortalecimento do PCK. No dia 17 de abril de 1975 os "Khmers Vermelhos" tomam a capital do país e põe fim à administração de Lon Nol. A partir de então instituem o regime do Kampuchea Democrático (KD) que governou o Camboja até 1979. No cargo de Secretário Geral do PCK e Primeiro Ministro do KD, Pol Pot cometeu crimes de genocídio, crimes contra a humanidade e agressão ao vizinho Vietnã, em quase quatro anos de poder. Ao aliar comunismo e xenofobia, foi responsável por mais de 1,7 milhão de mortes de cambojanos e minorias étnicas, trabalho forçado, além dos inúmeros refugiados de guerra em direção aos campos do Camboja ${ }^{9}$.

O regime de Pol Pot mantinha relações com a China e defendia uma política agressiva em relação ao Vietnã, por sua vez, apoiado pela União Soviética (ex- URSS). A causa antivietnamita, em um primeiro momento, atraiu o apoio e a cumplicidade norte-americana, mas as barbáries cometidas durante o governo de Pol Pot, tornaram-se, rapidamente, um impedimento para assim continuarem. O embate entre o Camboja e o Vietnã era sempre latente, até que em dezembro de 1978, tropas vietnamitas invadem o território vizinho e tomam a capital Phnon Penh em poucos dias. O regime dos "Khmers Vermelhos" cai no dia 07 de fevereiro do ano seguinte. Os remanescentes do grupo refugiam-se na fronteira tailandesa. Dissidentes cambojanos liderados pelo vietnamita Heng Samrin acabam assumindo o poder, e em 1982, as forças oposicionistas formam uma aliança com a aprovação da China e dos EUA ${ }^{10}$. Com a oposição da União Soviética, um grande confronto entre potências assolou o território cambojano.

Em 1989 iniciam-se os esforços de paz, e depois de diversas negociações internacionais, os vietnamitas deixam o território cambojano. Em 23 de outubro de 1991 no

\footnotetext{
9 "Nestes procedimentos não havia exceções e até os hospitais eram esvaziados e os pacientes deportados para o interior. O governo comunista do Khmer Vermelho alegava como causa destas providências a necessidade de alimentar a população urbana, do que era impedido pelos bombardeios das forças norte-americanas, que tornava qualquer meio de transporte inviável. Esta explicação foi imediatamente aceita pelos meios dominados pela esquerda marxista mundial, ficando toda a responsabilidade com os Estados Unidos. Embora tenham sido lançadas 539.129 toneladas de bombas sobre o território cambojano, quase quatro vezes mais do que as 153.000 toneladas recebidas pelo Japão durante a Segunda Grande Guerra, este não foi o motivo desta "evacuação". Seguindo-se a isto, o governo prossegue em seu programa de execuções, quando foram mortos tantos funcionários, policiais e militares quantos puderam ser encontrados. Qualquer indivíduo que houvesse trabalhado, de alguma forma, vinculado ao governo deposto, teria morte certa, caso fosse identificado. O Khmer não executava apenas o "vinculado", mas todos os seus familiares, para eliminar qualquer possibilidade de uma futura vingança contra o regime". História do Camboja. Disponível em: < http://www.saberweb.com.br>. Acesso em 06 out. 2010.

${ }^{10}$ A aliança era composta pelos seguintes dirigentes: Sihanouk (presidente), Son Sann (primeiro-ministro) e um dos líderes do Khmer Rouge, Khieu Samphan (vice-presidente).
} 
então governo Sihanouk, os "Khmers Vermelhos" e o grupo de Son Sann firmam um acordo de paz abrangente ${ }^{11}$ e aceitam a formação da Autoridade Transitória da Organização das Nações Unidas no Camboja (UNTAC). Estabelecida através da Resolução no ${ }^{\circ} 745$ de 28 de fevereiro de 1992 foi a primeira ocasião em que a ONU assumia a administração de um território independente. Tinha por missão o restabelecimento e a manutenção da paz, organização e direção de eleições livres e justas, o controle de todos os aspectos do governo (relações exteriores, defesa, finanças, segurança pública, etc.), fiscalizar a retirada das forças armadas estrangeiras, desmobilizar as facções de luta do Camboja, e, por fim, promover e garantir a defesa dos direitos humanos no Estado ${ }^{12}$.

Em maio de 1993, a UNTAC realizou as eleições que contou com a participação de mais de quatro milhões de cambojanos, ou seja, 90\% dos eleitores. O partido de Sihanouk, monarquista, vence as eleições parlamentares e forma um governo liderado por Hun Sen e composto por membros do antigo regime pró-vietnamita. Sihanouk é coroado rei da recémestabelecida monarquia parlamentarista e em setembro uma nova Constituição é promulgada.

No dia 21 de junho de 1997, o Governo do Camboja solicita às Nações Unidas, por meio de uma carta enviada para o Secretário Geral, assistência para trazer à justiça as pessoas responsáveis por genocídios e crimes contra a humanidade durante o regime do Khmer Vermelho (1975-1979). Os americanos, então, propõem a criação de uma comissão de inquérito ou comissão de verdade como um primeiro passo, para a posterior instauração de um tribunal penal que pudesse examinar as ações do regime do líder Pol $\operatorname{Pot}^{13}$. Com a prisão de Pol Pot em junho do mesmo ano, o interesse em criar um tribunal com jurisdição competente para processálo de forma credível tomou corpo. Sua morte no ano seguinte, aliado ao desejo americano de estabelecer um Tribunal Internacional para o Camboja com fulcro no Capítulo VII da Carta da ONU, portanto como órgão subsidiário do Conselho de Segurança e sede na Holanda, bem como a ocupação por membros dos "Khmers Vermelhos" em cargos importantes e estratégicos

\footnotetext{
${ }^{11}$ Embora amplos e abrangentes os Acordos de Paz de Paris (1991) não continham nenhuma referência explícita à justiça ou responsabilização pelos crimes do passado. As partes apenas comprometeram a "tomar medidas eficazes para garantir que as políticas e práticas do passado não serão autorizados a voltar”. Disponível em: < http://www.cambodia.org/ facts/?page $=1991+$ Paris + Peace + Agreements $>$. Acesso em 10 out. 2010.

${ }^{12}$ Disponível em: <http://www.un.org>.

${ }^{13}$ Negotiations between the UN and Cambodia regarding the establishment of the court to try Khmer Rouge leaders (Statement by UN Legal Counsel Hans Corell at a press briefing at UN Headquarters in New York). Disponível em: < http://www.un.org/News/dh/infocus/cambodia/corell-brief.htm>.
} 
no então governo de Hun Sen, acabaram por inviabilizar o prosseguimento das negociações ${ }^{14}$. O conflito no Camboja só termina em dezembro de 1998.

Em 15 de março de 1999, um grupo de peritos nomeado pelo Secretário-Geral propôs a criação de um Tribunal Internacional ${ }^{15}$. A empreitada não obteve êxito, pois Hun Sen, naquele momento o único primeiro-ministro, em outra carta dirigida ao Secretário-Geral, datada de 17 de Junho de 1999, modificou o pedido de um Tribunal. O interesse era estar em um Tribunal Nacional com a participação de juízes e procuradores internacionais. O Tribunal Internacional, portanto, não mais integrava os planos do Camboja.

Ainda assim, Estados-Membros das Nações Unidas apoiaram o prosseguimento dos esforços para a construção da justiça no Estado cambojano. E em três ocasiões (agosto de 1999, março e julho de 2000) enviaram delegações à Phnom Penh. No dia 07 de julho de 2000, o Subsecretário-Geral de Assuntos Jurídicos da ONU, Hans Corell, parte do Camboja acreditando ter concluído as negociações para a construção de um Tribunal, uma vez que, juntamente com o governo do Camboja, tinham apresentado para a apreciação da Assembleia Nacional o projeto do Estatuto e o texto do acordo a ser assinado entre as partes. As negociações entre o Camboja e as Nações Unidas se prolongou mais do que o esperado ou programado. Durante boa parte desse tempo, a iniciativa ficou restrita ao Governo do Camboja, embora tenham declarado reiteradas vezes que as Nações Unidas eram responsáveis pela morosidade do processo. Ocorre que, a partir de julho de 2000, a ONU foi quem esperou a atuação do governo e a consequente aprovação da lei que instituiu as Câmaras Extraordinárias.

Apenas no dia 02 de janeiro de 2001, a Assembleia Nacional do Camboja aprova o acordo com a ONU, no sentido de julgar os maiores responsáveis pelas atrocidades cometidas entre 1975 e 1979 por meio das denominadas Câmaras Especiais Criminais ${ }^{16}$. Em 08 de fevereiro de 2002, a ONU retira o apoio ao tribunal, alegando que o modelo não garantia a independência, imparcialidade e objetividade dos julgamentos. Em realidade, os Cambojanos pretendiam criar uma corte nacional, por meio de lei nacional e contar apenas com o apoio da ONU. Esta, por sua vez, foi categórica ao afirmar que não poderiam ser obrigados a cooperar por meio de uma lei nacional; daí a insistência, durante todo o processo de negociação, que, em

\footnotetext{
${ }^{14}$ Alguns, em particular a China, entendiam não haver mais qualquer ameaça à paz e à segurança internacionais no Camboja. Desse modo, o Conselho de Segurança não tinha autoridade legal para estabelecer um órgão judicial como um meio de aplicação da lei. Composite Chronology of the Evolution and Operation of the Extraordinary Chambers in the Courts of Cambodia. Disponível em: $<$ http://www.cambodiatribunal.org $>$. Acesso em 10 out. 2010.

${ }^{15}$ Ver UN doc. A/53/850 e S/1999/231.

${ }^{16}$ Importa ressaltar que em função da transição, no final de janeiro de 2001, para o governo Bush nos Estados Unidos, e, consequentemente, suas diferentes prioridades, a atenção americana para o processo judicial no Camboja infelizmente recuou. Disponível em: $<$ http://www.cambodiatribunal.org $>$.
} 
conformidade com a prática habitual, o Tribunal deveria ser instituído mediante a celebração de um acordo internacional entre as Nações Unidas e o Governo do Camboja, e a lei nacional deveria conformar-se ao conteúdo do acordo. Isso porque reduzir o acordo ao status de um documento meramente técnico-administrativo, subordinado à lei, seria privá-lo de seu fundamental papel de garantir a aplicação das normas e justiça internacionais, necessárias para a participação continuada das Nações Unidas.

Somente em 06 de junho de 2003, após novas negociações, as partes finalmente chegaram a um consenso e, assim, aprovaram um acordo assinado por ambos ${ }^{17}$. A Assembleia Geral da ONU ainda determinou que as despesas das Câmaras Extraordinárias do Camboja fossem suportadas por contribuições voluntárias da comunidade internacional. Mesmo assim, várias alterações foram realizadas nos meses seguintes e em 24 de abril de 2005 o acordo, devidamente formatado, entra em vigor, confirmado com os seguintes dizeres de Hun Sen:

\begin{abstract}
Letter from Samdech Hun Sen, Prime Minister, to Kofi Annan, Secretary General of the United Nations, stating: "A generation has passed since these crimes were committed. We cannot afford to lose any more time. I can assure you that we will do our utmost to ensure the Extraordinary Chambers may begin to function as soon as possible, and that they attain the level of international standards that we have both agreed on and that are needed to address the needs for justice of the Cambodian people and all humanity"18.
\end{abstract}

\title{
3. Base Jurídica Das câmaras extraordinárias do Camboja
}

A formatação jurídica final das Câmaras Extraordinárias do Camboja foi estruturada em três pilares: a Lei de estabelecimento das Câmaras Extraordinárias, formulada inicialmente em 10 de agosto de 2001, e posteriormente emendada ( $n^{\circ} .1004 / 6$, de 27 de outubro de 2004) $)^{19}$; o acordo firmado entre a Organização das Nações Unidas e o Camboja em 200120; e o Regimento Interno constitutivo das Câmaras Extraordinárias ${ }^{21}$.

Destaca-se que o acordo pactuado entre a ONU e o Camboja era categórico ao dispor que as leis cambojanas seriam aplicáveis aos julgamentos e todos os outros documentos interpretados sob essa legislação.

\footnotetext{
${ }^{17} \mathrm{O}$ acordo foi ratificado pela Assembléia Nacional do Camboja no dia 04 de outubro de 2004 e oficialmente promulgada em 19 de outubro do mesmo ano.

${ }^{18}$ Disponível em: $<$ http://www.eccc.gov.kh $>$.

${ }^{19}$ Disponível em: $<$ http://www.cambodiatribunal.org $>$.

${ }^{20}$ Disponível em: $<$ http://www.un.org $>$.

${ }^{21}$ Disponível em: $<$ http://www.cambodiatribunal.org $>$.
} 


\subsection{Direito Aplicável}

As Câmaras Extraordinárias julgam não só crimes comuns, mas, também, os denominados crimes internacionais. A tipificação e a descrição dos elementos constam na Lei de estabelecimento das Câmaras do Camboja. Assim, o Capítulo II da Lei - Competência define e elenca a jurisdição material do Tribunal. No caso dos crimes internacionais, além de elencá-los à lei, remete às Convenções específicas; com relação aos crimes comuns a referência é feita ao Código Penal do Camboja de 1956. As penas são limitadas à restrição de liberdade, sendo mínimo de cinco anos e máxima a perpétua. Já os bens e propriedades adquiridos de maneira ilícita, são confiscados e retornam para o Estado ${ }^{22}$.

No que diz respeito ao direito processual, é de se destacar que se aplicam as disposições específicas do acordo entre a ONU e o Camboja, bem como o Código de Processo Penal cambojano, desde que suas regras sejam compatíveis com as normas processuais internacionais. Isto é, além de preencherem possíveis lacunas, o fato de o Camboja ser signatário do Estatuto de Roma, implica a aceitação e adequação de regras de procedimentos, provas, princípios processuais em todos os seus julgamentos. Portanto, essas normas, com todos seus elementos e princípios, foram incorporadas pelo Camboja. Enfim, são aplicadas tanto no TPI, quanto nas Câmaras Extraordinárias do Camboja.

\subsection{Competências Específicas}

Nesse ponto específico serão dispostas a atuação e os limites da Câmara Extraordinária do Camboja no que diz respeito às matérias (3.2.1), aos fatos objetos da entrega da prestação jurisdicional (3.2.2), ao espaço de incidência (3.2.3), e, por último, aos sujeitos (3.2.4).

\subsubsection{Competência ratione materiae}

Conforme previsão do Estatuto para o estabelecimento das Câmaras Extraordinárias nas Cortes do Camboja, todos os suspeitos de cometer os crimes comuns constantes no Código Penal Cambojano de 1956, no período de 17 abril de 1975 a 06 de Janeiro de 1979, serão levados a julgamento. Desse modo, elenca homicídio, tortura e perseguição religiosa, bem

\footnotetext{
${ }^{22}$ Art. 38 e 39 da Lei da Câmara Extraordinária do Camboja. Disponível em: < http://www.cambodiatribunal.org>.
} 
como seus respectivos artigos. Prorroga, ainda, o prazo prescricional desses crimes por mais 30 anos, além do já estabelecido pelo Código Penal, e limita a pena a um máximo de prisão perpétua $^{23}$.

Com relação aos crimes internacionais listam os seguintes: genocídio, tal qual definido pela Convenção de 1948 e pelo Estatuto do TPI; crimes contra a humanidade, conforme tipificação do Estatuto do TPI e do TIPY; graves violações das Convenções de Genebra de 12 de agosto de 1949; destruição de bens culturais durante conflitos armados, nos termos da Convenção de Haia de 1954 para a Proteção dos Bens Culturais em Caso de Conflito; e crimes contra as pessoas protegidas internacionalmente, de acordo com a Convenção de Viena de 1961 sobre Relações Diplomáticas ${ }^{24}$. Importa observar que o Estatuto é silente no que se refere à imprescritibilidade dos crimes. Assim, a previsão restringe-se, apenas, às Convenções de genocídio e aos crimes contra a humanidade que dispõem expressamente sobre o assunto.

\subsubsection{Competência ratione temporis}

Primeiramente, é de se ressaltar que ao fixar a jurisdição temporal de qualquer tribunal, as Nações Unidas pretendem alcançar um equilíbrio entre a especificação do lapso temporal, suficientemente abrangente para abarcar os crimes mais graves, e as atividades a serem desenvolvidos pelo Ministério Público e pelo Tribunal, com vistas, sempre, a atingir objetividade, eficiência, custo-benefício, justiça e imparcialidade na condução dos processos e julgamentos.

Assim, a jurisdição temporal das Câmaras Extraordinárias do Camboja será limitada ao período do regime de Pol Pot, qual seja de 17 de abril de 1975 a 06 de janeiro de 1979. Assim, apenas os crimes cometidos nesse intervalo serão investigados pela $\mathrm{CEC}^{25}$.

\subsubsection{Competência ratione loci}

Ao contrário do estabelecido nos estatutos dos outros Tribunais Híbridos, ou mesmo do Tribunal Penal Internacional para a ex-Iugoslávia e Ruanda, a lei que estabelece as Câmaras Extraordinárias nas Cortes do Camboja não explicita a competência territorial, ou área de abrangência para o julgamento dos crimes cometidos durante o período democrático

\footnotetext{
${ }^{23}$ Art. 3 da Lei da Câmara Extraordinária do Camboja. Disponível em: < http://www.cambodiatribunal.org>.

24 Art. 4, 5, 6, 7 e 8 da Lei da Câmara Extraordinária do Camboja. Disponível em: < http://www.cambodiatribunal.org>.

${ }^{25}$ Art. 4 e 5 da Lei da Câmara Extraordinária do Camboja. Disponível em: < http://www.cambodiatribunal.org>.
} 
Kampuchea. Talvez, por ser uma Corte nacional do Camboja a previsão seja a clássica, isto é, como qualquer órgão jurisdicional nacional, encontra limites em sua própria base territorial.

\subsubsection{Competência ratione personae}

Poderão ser investigados, processados e julgados pelas Câmaras Extraordinárias, apenas os líderes seniores do partido Kampuchea e, desde que considerados os maiores responsáveis pelos graves crimes sob jurisdição do Tribunal ${ }^{26}$. Importa destacar que somente cinco líderes do partido foram formalmente acusados perante a Câmara ${ }^{27}$. Este pequeno grupo demonstra que a finalidade primordial do órgão é investigar, processar e punir os principais líderes do regime de Pol Pot pelas atrocidades cometidas no período de 1975 ao início de 1979. Pode-se dizer, ainda, que reflete, igualmente, a capacidade e os limitados recursos da CEC para a realização das investigação e dos julgamentos.

\section{Relação com o Sistema Jurídico Interno}

As Câmaras Extraordinárias foram inseridas no sistema judiciário do Camboja, com sede em Phnom Penh ${ }^{28}$. É certo que, em função dos conflitos, assim como nos outros Estados que possuem Tribunais Híbridos, careciam de organização e respeito às normas e princípios bases para um julgamento justo e imparcial. Assim, uma Câmara foi instituída na Corte de Primeiro Grau e a outra junto à Suprema Corte. Vale observar, por fim, que julgam, principalmente, crimes internacionais, possuindo, ainda competência exclusiva para a análise e juízo de validade para a concessão de perdão ou anistia ${ }^{29}$.

\footnotetext{
${ }^{26}$ Art. 2 da Lei da Câmara Extraordinária do Camboja. Disponível em:<http://www.cambodiatribunal.org>.

${ }^{27}$ São eles: Kaing Guek Eav (um dos líderes do Khmer Vermelho), Nuon Chea (vice-secretário do Comitê Central e membro do Comité Permanente, órgãos mais altos e responsáveis pela política do Partido Khmer Vermelho), Ieng Sary (vice-Primeiro-Ministro e Ministro dos Negócios Estrangeiros do Kampuchea Democrático), Khieu Thirith (esposa de Ieng Sary e irmã-de-lei de Pol Pot, era membro sênior do regime Kampuchea Democrático. Ocupou cargos na área da cultura, assistência social e foi solidariamente responsável com o marido, Ieng Sary, nos Negócios Estrangeiros), Khieu Samphan (Presidente do Presídio do Estado do Kampuchea Democrático, ocupou, igualmente, a chefia do estado e foi um dos funcionários mais poderosos do movimento Khmer Vermelho).

${ }^{28}$ Art. 43 da Lei da Câmara Extraordinária do Camboja. Disponível em:<http://www.cambodiatribunal.org>.

${ }^{29}$ Art. 40 da Lei da Câmara Extraordinária do Camboja. Disponível em:<http://www.cambodiatribunal.org>.
} 


\section{Composição das Câmaras Extraordinárias}

As Câmaras Extraordinárias estabelecidas no Camboja inserem-se no sistema judiciário Cambojano. São três Câmaras que contam com um total de 17 juízes escolhidos conjuntamente pelo Estado do Camboja e pelas Nações Unidas, com mandato coincidente à duração de todos os procedimentos e investigações. A Câmara de Julgamento de Primeiro Grau é composta por cinco juízes, dos quais três nacionais, sendo um o Presidente, e dois estrangeiros ${ }^{30}$.

A Câmara da Corte Suprema, por sua vez, funciona tanto como órgão recursal, quanto instância final, e é composta por sete juízes, dos quais quatro cambojanos e três estrangeiros. Assim como a Câmara de Primeira Instância, é presidida por um cambojano ${ }^{31}$. Importa destacar que todos os sete juízes Cambojanos, bem como seus substitutos são indicados pelo Conselho Superior da Magistratura. Este Conselho designa, igualmente, os cinco estrangeiros constante de uma lista com, pelo menos, sete nomes indicada pelo Secretário Geral da ONU ${ }^{32}$.

As decisões das Câmaras Extraordinárias são proferidas obedecendo ao quórum de maioria qualificada. Desse modo, são necessários quatro votos na primeira instância e cinco para a segunda; em síntese os juízes internacionais gozam do direito ao veto ${ }^{33}$.

Em um compromisso entre diferentes tradições jurídicas, quais sejam common law e civil law, as Câmaras são dotadas de uma Procuradoria consistente, ao mesmo tempo em que monitora seus magistrados. Ressalta, portanto, pontos fortes de dois sistemas, criando um órgão único entre os Tribunais Híbridos. Assim, as responsabilidades de cada cargo são compartilhadas entre nacionais e estrangeiros. Em outras palavras, existem dois co-juízes de Instrução e dois co-procuradores ${ }^{34}$.

Todas as denúncias, investigações, pedidos de indiciamentos e processos são de sua responsabilidade conjunta. Caso haja discordância de posicionamentos, a Câmara de préjulgamento, de composição idêntica a de Primeira Instância, decide definitivamente sobre a matéria.

\footnotetext{
${ }^{30}$ Art. 9 da Lei da Câmara Extraordinária do Camboja. Disponível em: $<$ http://www.cambodiatribunal.org $>$.

${ }^{31}$ Art. 10 da Lei da Câmara Extraordinária do Camboja. Disponível em: $<$ http://www.cambodiatribunal.org $>$.

32 Art. 11 da Lei da Câmara Extraordinária do Camboja. Disponível em: $<$ http://www.cambodiatribunal.org $>$.

${ }^{33}$ Art. 14 da Lei da Câmara Extraordinária do Camboja. Disponível em: $<$ http://www.cambodiatribunal.org $>$.

${ }^{34}$ Com relação ás funções dos Procuradores ver artigos 16, 17, 18, 19, 20, 21 e 22 da Lei da Câmara Extraordinária do Camboja. Disponível em: $<$ http://www.cambodiatribunal.org $>$.
} 
Do mesmo modo, a estrutura administrativa e de financiamento são compartidas e controladas pelo Camboja e pela $\mathrm{ONU}^{35}$. As línguas oficiais dos trabalhos são três: Khmer, Inglês e Francês ${ }^{36}$. Atualmente, existem dois processos em andamento no Tribunal, o primeiro contra Kaing Guek Eav, indicado em agosto de 2008 por crimes contra a humanidade, violações às Convenções de Genebra de 1949, e homicídio e tortura, nos termos do Código Penal Cambojano. Atualmente encontra-se em fase de julgamento ${ }^{37}$. O segundo, Nuon Chea, está, desde 2008, sob investigação de autoria dos seguintes crimes: contra a humanidade, guerra, genocídio, homicídio, tortura e perseguição religiosa, nos termos do Código Penal do Camboja.

\section{Fontes de Financiamento}

Os recursos para o custeio das despesas relativas à manutenção das Câmaras Extraordinárias do Camboja são provenientes de diferentes fontes, pois estão vinculados à natureza dos gastos. Assim, as despesas relacionadas com a composição nacional das Câmaras (funcionários, juízes e promotores), ficam a cargo do governo cambojano, as relativas ao staff internacional são de responsabilidade da ONU. Além disso, o Estatuto sobre o Estabelecimento das Câmaras Extraordinárias aprovada pelo governo cambojano prevê que o advogado de defesa pode receber taxas pela prestação de serviços e que contribuições voluntárias de países estrangeiros, organizações internacionais, ONGs, são admitidas. A exigência média anual para a manutenção das atividades das Câmaras é de aproximadamente seis milhões de dólares.

\section{Conclusões}

A partir da análise do conflito do Camboja, bem como do processo de construção das Câmaras extraordinárias e seus respectivos aspectos constitutivos, é possível observar o crescente movimento de reconstrução e efetiva proteção de direitos humanos, colocados como

\footnotetext{
35 Art. 30, 31 e 32 da Lei da Câmara Extraordinária do Camboja. Disponível em: $<$ http://www.cambodiatribunal.org $>$.

${ }^{36}$ Art. 45 da Lei da Câmara Extraordinária do Camboja. Disponível em: $<$ http://www.cambodiatribunal.org $>$.

37 "In August 2008, the Co-Investigating Judges found that there was sufficient evidence to indict Duch for crimes against humanity and grave breaches of the Geneva Conventions of 1949. According to the Co-Investigating Judges' Closing Order, the investigation demonstrated that, while Duch was not a senior leader of Democratic Kampuchea, he may be considered one of those most responsible for crimes and serious violations committed between 17 April 1975 and 6 January 1979, due to his hierarchical authority and his personal participation as Deputy Secretary then Secretary of S-21. The Pre-Trial Chamber subsequently amended the Closing Order to include an indictment for the domestic crimes of homicide and torture". Disponível em: <http://www.eccc.gov.kh $>$.
} 
paradigmas da ordem internacional contemporânea. A repressão de conflitos armados, a defesa da pluralidade religiosa, étnica e política, ou mesmo a luta contra a impunidade devem ser objetivos constantemente perseguidos, inobstante o fato de se tratar de uma tarefa longa e árdua.

A crescente percepção de que certos crimes cometidos dentro de um território nacional possuem repercussão em âmbito internacional, além de violarem direitos individuais básicos e indisponíveis, traz consigo a necessidade de se desenvolver um sistema de preservação da paz. Desse modo, conflitos intraestatais que até então não se inseriam na competência do Conselho de Segurança, assumem caráter transnacional, tornando-se objeto das resoluções emitidas com fulcro no Capítulo VII da Carta da ONU.

Os direitos humanos, por sua vez, passam a ser considerados fundamentais para qualquer sistema legal, sobrepondo-se, até mesmo, às normas internas dos Estados, o que evidencia o reconhecimento do vínculo existente entre o plano interno e a realidade internacional.

É necessário compreender que uma sociedade livre da impunidade, baseada em uma cultura de responsabilidade e compromissada com a construção da verdade e da justiça, institui pilares sólidos na busca da realização e respeito aos direitos humanos.

Desse modo, a instauração de um Tribunal imparcial, independente, guiado por princípios e normas internacionais representa uma medida não só para salvaguarda dos direitos das minorias, mas para o restabelecimento da paz e segurança, auxílio humanitário, político, e mesmo para a reabilitação das principais funções institucionais do Governo local. Isso porque possibilita a adequação da legislação nacional aos parâmetros estabelecidos pelo corpo jurídico internacional, ao mesmo tempo em que zela pelo cumprimento e aplicação da lei, pelo fim da impunidade, auxiliando, de forma reflexa, a reconstrução e capacitação do sistema judicial local. É encorajador perceber que este legítimo desejo de justiça, responsabilidade e proteção às diferenças ganha, paulatinamente, maior impulso.

\section{Referências bibliográficas}

AMARAl JÚNIOR, Alberto do. O Direito de Assistência Humanitária. Rio de Janeiro: Renovar, 2003. (Coleção Biblioteca de Teses).

AMBOS, K.; OHTMANN, M. New approaches in international criminal justice: Kosovo, East-Timor, Sierra Leone and Cambodia. Freiburg im Breisgau: editora, 2003. 
ARAÚJO, Luis Ivani de Amorim. Direito internacional penal: delicta iuris gentium. Rio de Janeiro: Forense, 2000.

ASCENCIO, Hervé. O Desenvolvimento do Direito Internacional Penal. In: BRANT, Leonardo Nemer Caldeira (Coord.). O Brasil e os Novos desafios do Direito Internacional. Rio de Janeiro: Forense, 2004. p. 265-285.

ASCENSIO, Hervé; DECAUX, Emmanuel; PELLET, Alain. Chapitre 1: Introduction. In: ASCENSIO, Hervé; DECAUX, Emmanuel; PELLET, Alain. Droit International Pénal. Paris: A. Pedone, 2000. p. 1-3.

BASS, Gary Jonathan. Stay the Hand of Vengeance: the politics of war crimes Tribunals. Princeton: Princeton University Press, 2000.

BASSIONI, Mahmoud Cherif. International Criminal Law: Sources, Subjects and Contends. 3 ed. New YorK: Brill, 2008.

BASSIOUNI, Mahmoud Cherif. Chapitre 54: L'Expérience dês Prémières Jurisdictions Pénales Internationales. In: ASCENSIO, Hervé; DECAUX, Emmanuel; PELLET, Alain. Droit International Pénal. Paris: A. Pedone, 2000. p. 635-659.

BURGENTHAL, Thomas. Proliferation of International Courts and Tribunals: Is it Good or Bad? Leiden Journal of International Law, Cambridge, vol. 14, p. 267-275, 2001.

CASSESE, Antonio. International Criminal Law. New York: Oxford University Press Inc, 2003.

CASSESE, Antonio. Existe um conflito insuperável entre soberania dos Estados e Justiça Penal Internacional? In: CASSESE, Antonio, DELMAS-MARTY, Mireille (organ.). Crimes Internacionais e Jurisdições Internacionais. Trad.: Silvio Antunha. Barueri: Manole, 2004. p. 3-24. 
CASSESSE, Antonio. The Role of Internationalized Courts and Tribunals in the Fight Against International Criminality In: Internationalized Criminal Courts: Sierra Leone, East Timor, Kosovo, and Cambodia. Oxford: Oxford University Press, vol. 1, n. 13, 2004. p. 552.

COBBAN H. The Palestinian Liberation Organization: People, Power and Politics, Cambridge University Press, 1984.

COHEN, David. Hybrid Justice in East Timor, Sierra Leone, and Cambodia: Lessons Learned and Prospects for the Future. Stanford Jounal of International Law, Stanford vol.1, n ${ }^{\circ}$. 1, 2007

COCKAYNE, James. The Fraying Shoestring: Rethinking Hybrid War Crimes Tribunals. Fordham International Law Journal. vol. 28, 2004, p. 616-680.

COMPARATO, Fábio Konder. A afirmação histórica dos direitos humanos. 3. ed. rev. ampl. São Paulo: Saraiva, 2003.

DEL VECCHIO, Angela. I Tribunali internazionali tra globalizzazione e localismi. Bari: Cacucci Editore, 2009.

DELGADO, José M. A. Pina, TIUJO, Liriam K. Tribunais Penais Internacionais. In: BARRAL, Welber. Tribunais Internacionais: Mecanismos contemporâneos de solução de controvérsias, Florianópolis: Fundação Boiteux, 2004.

DICKINSON, Laura A. The Promise of Hybrid Courts. American Journal of International Law, Washington, vol. 97, 2003, p. 295-310.

FASSBENDER, Bardo. Reflectionson the International Legality of the Special Tribunal for Lebanon. Journal of International Criminal Justice, Oxford, v. 5, n. 5, p. 1092-1105, nov. 2007.

FERREIRA JÚNIOR, Lier Pires; MACEDO, Paulo Emílio Vauthier Borges de (coords.). Direitos Humanos e Direito Internacional.Curitiba: Juruá, 2006. 
GAETA, Paola. Trials in Absentia before the Special Tribunal for Lebanon. Journal of International Criminal Justice, Oxford, v. 5, n. 5, p. 1165-1174, nov. 2007.

INGADOTTIR, Thordis. The Financing of Internationalized Courts and Tribunals. In: ROMANO, Cesare P. R.; NOLLKAEMPER, André; KLEFFNER, Jann. Internationalized criminal courts: Sierra Leone, East Timor, Kosovo and Cambodia. Oxford: Oxford University Press, 2004.

KITTICHAISAREE, Kriangsak. International Criminal Law. New York: Oxford University Press Inc., 2001.

MELLO, Celso Duvivier de Albuquerque. Direitos humanos e conflitos armados. Rio de Janeiro: Renovar. 1997.

MORE, Rodrigo Fernandes. A prevenção e solução de litígios internacionais no direito penal internacional: fundamentos, histórico e estabelecimento de uma corte penal internacional (Tratado de Roma, 1998). Jus Navigandi, Teresina, ano 6, n. 55, mar. 2002. Disponível em: $<$ http://jus2.uol.com.br/doutrina/texto.asp?id=2819>.

NOUWEN, Sarah. Hybrid courts: the hybrid category of a new type of international crimes courts. Utrecht Law Review, Utrecht, v.2, n.2, 2006. p. 190-214.

PELLET, Alain. Direito Internacional Público. Trad. Vítor Marques Coelho. Lisboa: Fundação Calouste Gulbenkian, 2003.

ROMANO, Cesare P. R.; NOLLKAEMPER, Andre; KLEFFNER, Jann K. Internationalized Criminal Courts and Tribunals: Sierra Leone, East Timor, Kosovo, and Cambodia. Oxford, U.K.: Oxford University Press, 2004. 550pp.

SUNGA, Lyal S. The Emerging System of International Criminal Law: Developments in Codification and Implementation. The Hague: Kluwer Law International, 1997. 
E

—ste livro reúne artigos científicos apresentados e debatidos nos Grupos de Trabalho: "DIREITO INTERNACIONAL" e "DIREITO INTERNACIONAL DOS DIREITOS HUMANOS" no decorrer do VIII Encontro Internacional do CONPEDI (Conselho Nacional de Pesquisa e Pós-Graduação em Direito Brasil), realizado entre os dias 06 e 08 de setembro de 2018 na cidade de Zaragoza - Espanha. 